Научное издание Нижнетагильского государственного социально-педагогического института (филиала) ФГАОУ ВО «Российский государственный профессионально-педагогический университет»
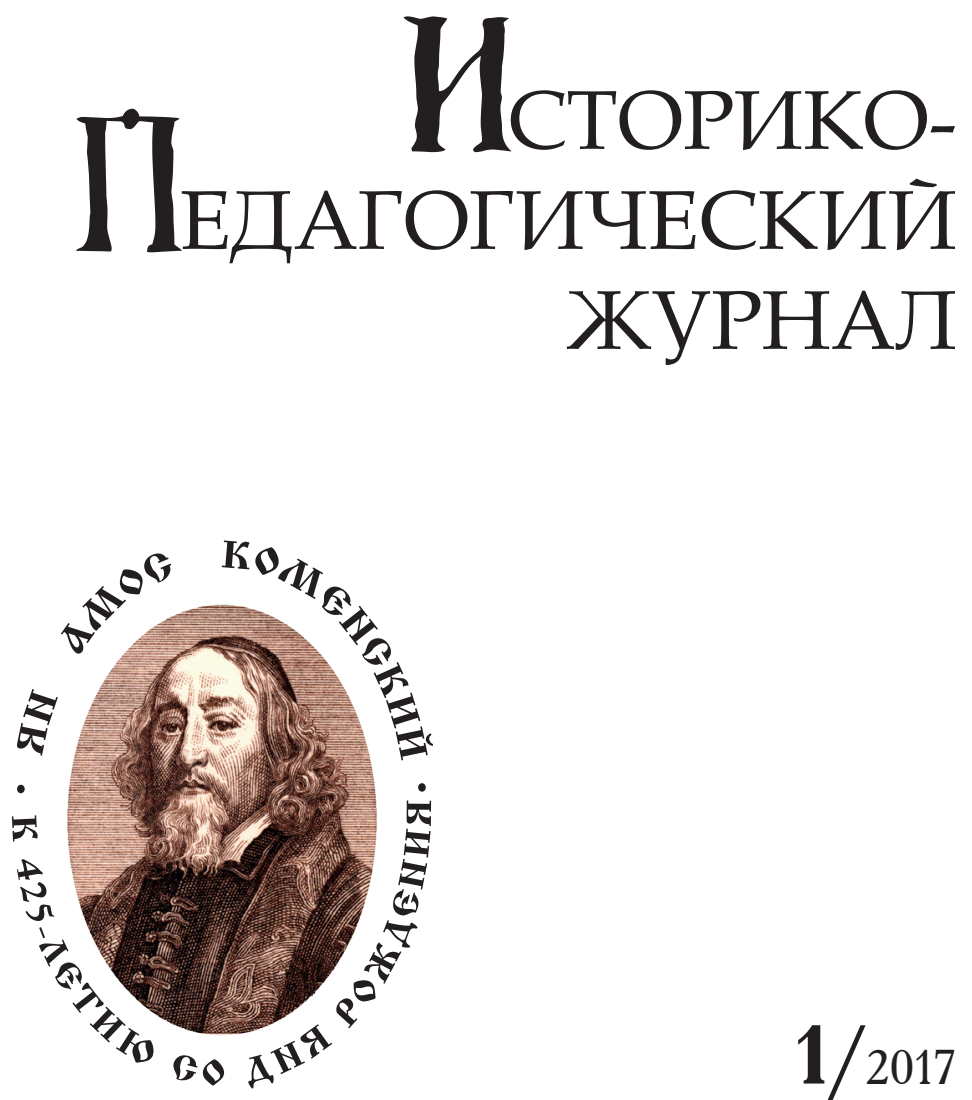
УДК 37.01

ББК 74.03

И 902

\section{РЕДАКЦИОННЫЙ СОВЕТ «ИСТОРИКО-ПЕДАГОГИЧЕСКОГО ЖУРНАЛА»}

УТКИН Анатолий Валерьевич - главный редактор, доктор педагогических наук, профессор кафедры педагогики и психологии НТГСПИ (ф) РГППУ, г. Нижний Тагил

КОРНЕТОВ Григорий Борисович - председатель редакџионного совета, доктор педагогических наук, профессор, заведуюший кафедрой педагогики ГБОУ ВО МО «Академия соџиального управления», г. Москва

АНТОНОВА
Лидия
Николаевна
БЕЗРОГОВ
Виталий
Григорввич
ДОРОЖКИН
Евгений
Михайлович
КАРОЛИ
Дорена
АУКАЦКИЙ
Михаил
Абрамович
МИСЕЧКО
Ольга
Евгенввна
ООГАЧЕВА
Елена
Юрвевна
ООМАНОВ
Алексей
Алексеевич
САВИН
Михаи
Викторович
САЛОВ
Александ
Игоревич
СНАПКОВСКАЯ
Светлана
Валентиновна

\section{ЧЛЕНЫ РЕДАКЦИОННОГО СОВЕТА:}

доктор педагогических наук, профессор, академик РАО, депутат Государственной думы $\mathrm{PФ}$, член комитета Государственной Думы по образованию, член Президиума Российской академии образования

доктор педагогических наук, профессор, член-корреспондент РАО.

Ведуший научный сотрудник ФГНУ «Институт стратегии и теории образования» $\mathrm{PAO}$, г. Москва

доктор педагогических наук, профессор.

Ректор ФГАОУ ВО «Российский государственный профессиональнопедагогический университет», г. Екатеринбург

доктор исторических наук, профессор истории образования Университета Мачерата (Италия)

доктор педагогических наук, профессор, член-корреспондент РАО.

Заведуюший лабораторией теоретической педагогики и философии образования ФГНУ «Институт стратегии и теории образования» $\mathrm{A}$ А, г. Москва

доктор педагогических наук, профессор.

Профессор Института иностранной филологии Житомирского государствен-

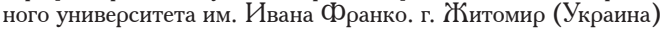

доктор педагогических наук, профессор.

Профессор кафедры педагогики ФГБОУ ВО «Владимирский государственный университет им. А. Г. и Н. Г. Столетовых», г. Владимир

доктор педагогических наук, профессор.

Заведуюший кафедрой педагогики и педагогического образования

ФГБОУ ВО «Рязанский государственный университет им. С. А. Есенина», г. Рязань

доктор педагогических наук, профессор.

Профессор кафедры криминалистики ФГКОУ ВО «Волгоградская академия МВД России», г. Волгоград

кандидат педагогических наук, доџент.

Ректор ГБОУ ВО МО «Академия соџиального управления», г. Москва

WEBEЛEB

Александр

Николаевич

доктор педагогических наук, доктор исторических наук, профессор.

Профессор кафедры культурологии Белорусского государственного университета, заместитель председателя по вопросам культуры, педагогики и образования СНКА «Белорусы России», г. Минск (Беларусь).

доктор педагогических наук, профессор.

Заведуюший кафедрой педагогики и андрагогики ГБОУ ДПО (повышения квалификаџии) спеџиалистов «Санкт-Петербургская академия постдипломного педагогического образования», г. Санкт-Петербург

ЮДИНА

Надежда

Петровна

доктор педагогических наук, профессор.

Профессор кафедры педагогики Педагогического института ФГБОУ ВО «Тихоокеанский государственный университет», г. Хабаровск

СМИРНОВА Лариса Владимировна - ответственный редактор.

Кандидат педагогических наук, доџент, начальник отдела научных работ и подготовки научно-педагогических кадров НТГСПИ (ф) РГППУ, г. Нижний Тагил 


\section{СОДЕРЖАНИЕ}

\section{КОЛОНКА РЕДАКТОРА}

Уткин А. В.,

д-р пед. наук, доцент

ИСТОРИКО-ПЕДАГОГИЧЕСКИЙ КОНТЕКСТ

КАК ПРОСТРАНСТВО РЕФЛЕКСИИ ПРОБЛЕМ

СОВРЕМЕННОГО ОБРАЗОВАНИЯ .7

\section{ПАМЯТНЫЕ ДАТЫ ИСТОРИИ ОБРАЗОВАНИЯ И ПЕДАГОГИКИ}

Корнетов Г. Б.,

д-р пед. наук, профессор

ЯН АМОС КОМЕНСКИЙ

И ВОЗНИКНОВЕНИЕ ПЕДАГОГИЧЕСКОЙ

НАУКИ

Коменский Я. А.

МАТЕТИКА, То есть НАУКА УЧЕНИЯ

.22

Шевелев А. Н.,

д-р пед. наук, доцент

ДЕМИДОВСКИЕ УЧЕБНЫЕ ЗАВЕДЕНИЯ

ДОРЕВОЛЮЦИОННОГО ПЕТЕРБУРГА

(к 170-летию со дня основания)

.27

Корнетов Г. Б.,

\section{МЕТОДОЛОГИЯ И МЕТОДИКА ИСТОРИКО-ПЕДАГОГИЧЕСКОГО ИССЛЕДОВАНИЯ}

д-р пед. наук, профессор

ТРИ РАКУРСА ИЗУЧЕНИЯ ПЕДАГОГИЧЕСКОГО

НАСЛЕДИЯ ПРОШЛОГО:

ИСТОРИЯ ПЕДАГОГИКИ,

ПЕДАГОГИЧЕСКАЯ ИСТОРИЯ,

ИСТОРИЧЕСКАЯ ПЕДАГОГИКА 


\section{МЕТОДИКА ПРЕПОДАВАНИЯ}

Севенюк С. А.,

канд. пед. наук, доцент,

Парфенова Т. А.

МОДУЛЬНО-РЕЙТИНГОВАЯ ПОДГОТОВКА

БУДУЩИХ ПЕДАГОГОВ ПО ДИСЦИПЛИНЕ

«ИСТОРИЯ ОБРАЗОВАНИЯ

И ПЕДАГОГИЧЕСКОЙ МЫСЛИ

В РОССИИ И ЗА РУБЕЖОМ» .56

\section{ИСТОРИЯ ОТЕЧЕСТВЕННОГО ОБРАЗОВАНИЯ И ПЕДАГОГИКИ}

Астафьева Е. Н.

ИНСТИТУТ ШКОЛЫ В ПЕДАГОГИЧЕСКОМ

НАСЛЕДИИ Н. В. ЧЕХОВА

Помелов В. Б.,

д-р пед. наук, профессор

ВЫДАЮЩИЙСЯ ПРОСВЕТИТЕЛЬ

ВЯТСКОЙ ЗЕМЛИ

ЕПИСКОП ЛАВРЕНТИЙ ГОРКА

Фуртова Г. А.

ТЕХНИЧЕСКИЕ СРЕДСТВА ОБУЧЕНИЯ

В ПРАКТИКЕ РОССИЙСКОГО ОБРАЗОВАНИЯ

XIX - начала XX вв. 


\section{ИСТОРИЯ ЗАРУБЕЖНОГО ОБРАЗОВАНИЯ И ПЕДАГОГИКИ}

Савина А. К., д-р пед. наук, профессор

О КУЛЬТУРОЛОГИЧЕСКОМ СМЫСЛЕ СОДЕРЖАНИЯ ОБРАЗОВАНИЯ

В ПОЛЬСКОЙ ОБЩЕОБРАЗОВАТЕЛЬНОЙ ШКОЛЕ: ИСТОРИКО-ГЕНЕТИЧЕСКИЙ АСПЕКТ ПРОБЛЕМЫ

Яковлева Н. Р.

ВИННЕТКА-ПЛАН КАРЛТОНА УОШБЕРНА

В РОССИИ:

ПУБЛИКАЦИИ И ИССЛЕДОВАНИЯ

129

\section{ИСТОРИЯ ПЕДАГОГИЧЕСКОЙ КРИТИКИ}

Сергиенко И. А., канд. филол. наук, доцент

МАРИЯ КОНСТАНТИНОВНА ЦЕБРИКОВА:

СТРОГИЙ КРИТИК

Головин В. В.,

д-р филол. наук, профессор

ЕВГЕНИЙ ЕЛАЧИЧ -

КРИТИК ДЕТСКОЙ ЛИТЕРАТУРЫ 154

Маслинская С. Г., канд. филол. наук

НЕУТОМИМЫЙ БОРЕЦ СО СКАЗКОЙ (КРИТИКА ДЕТСКОЙ ЛИТЕРАТУРЫ В ТРУДАХ Н. КРУПСКОЙ). 
6 ………….Историко-педагогический журнал, № 1, 2017

\section{НАучныЕ ДИСКУСсии}

Новиков С. Г.,

Д-р пед. наук, профессор

«Я СЕБЯ ПОД ЛЕНИНЫМ ЧИЩУ...»:

СОВЕТСКИЕ ВОЖДИ 1920-Х ГОДОВ

ОБ ИДЕАЛЕ ВОСПИТАНИЯ

\section{ОБРАЩАЯСЬ К ИСТОЧНИКАМ}

Плюснин-Кронин Б. А.

ПУТИ И ЦЕЛИ

РЕВОЛЮЦИОННОЙ ПЕДАГОГИКИ 196

СВЕДЕНИЯ ОБ АВТОРАХ .206

ИНФОРМАЦИЯ ДЛЯ АВТОРОВ .209 
Колонка редактора

\title{
КОЛОНКА РЕДАКТОРА
}

\author{
А. В. Уткин \\ д-р пед. наук, доцент
}

\section{ИСТОРИКО-ПЕДАГОГИЧЕСКИЙ КОНТЕКСТ КАК ПРОСТРАНСТВО РЕФЛЕКСИИ ПРОБЛЕМ СОВРЕМЕННОГО ОБРАЗОВАНИЯ}

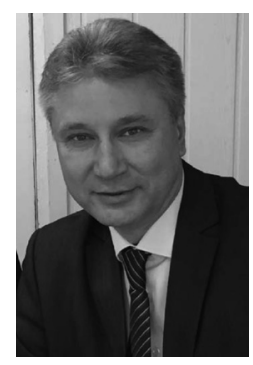

УДК 001.8:37

ББК 74в

Использование метода контент-анализа при изучении текстов научных статей, представленных в «Историко-педагогическом журнале» в их соџиально-педагогическом и историко-педагогическим контексте, позволило выявить обшие тенденџии, связанные с подходами к решению насушных проблем современного образования.

Ключевые слова: историко-педагогические исследования; контекст и контекстуальность; историко-педагогический контекст.

A. V. Utkin

\section{Historical AND PEDAGOGICAL CONTEXT AS THE SPACE OF REFLECTION OF MODERN EDUCATION PROBLEMS}

The usage of content analysis in the study of the texts of scientific articles presented in «Historical and pedagogical journal» in the socio-pedagogical and historical and pedagogical context revealed general trends in approaches to solving the urgent problems of modern education.

Key words: historical and pedagogical research; context and contextuality; historical and pedagogical context.

Движение в прошлое от какой-то точки, которая становится для исследователя условным настоящим, имеет смысл, если прошлое и настояшее сопрягаются как минимум в двух направлениях. Для историко-педагогических исследований это отражается, с одной стороны, в стремлении установить дистанџию между прошлым и настояшим, показать, чем государственно-политическое устройство, ментальность и культура обшества, функџионирование систем образова- 
ния и транслируемых в них џенностей прошлого отличаются от настоящего. С другой стороны, сам интерес к прошлому продиктован желанием понять его и тем самым приблизить к современности, сомкнуть прошлое с настояџим или, во всяком случае, включить его в культуру настояшего.

Историко-генетическая реконструкџия, объяснение и понимание педагогического прошлого (объектов, проџессов, событий, сюжетов) предполагает по возможности полный охват и систематизаџию источников, относяџихся к изучаемому периоду, критический анализ всей совокупности фактов. Вместе с тем, каждый исследователь с помоџью логики и интуиџии создает свой, отличный от современного, мир. Мы полностью согласны с мнением Г. Б. Корнетова, считаюшего, что историко-педагогическое знание в широком смысле - субъективный образ педагогической реальности прошлого, выраженный в понятиях и представлениях.

Являясь наукой педагогической, история педагогики предстает логически и функџионально, как наука историческая, так как рассматривает педагогические феномены прошлого в проџессе их генезиса, эволюџии. С точки зрения Б. М. Бим-Бада, ни один педагогический феномен непонятен, если не поместить его в контекст развития всей системы, в эволюџионный проџесс, частичку которых этот феномен составляет; функџионирование любого образовательного феномена прошлого обусловлено рядом детерминант, или контекстом.

В философском понимании контекст - это среда, в которой сушествует объект, поэтому контекст можно рассматривать и как совокупность соџиальноисторических и культурных условий, которые позволяют уточнить смысловое значение результатов деятельности человека, и как совокупность различных факторов, необходимых для понимания, объяснения какого-либо явления действительности.

С формальной точки зрения, контекст представляет собой определенную систему отсчета, некое пространство имен и событий, которое фиксируется в научных текстах. В этой связи следует отметить важнейшую особенность научных текстов, а именно: для отдельного научного текста контекстом является корпус других научных текстов, исследующих данную проблематику. Так, В. К. Пичугина, рассматривая лингвистический и исторический аспекты дискурса в педагогике, отмечает, что авторы педагогических конџепџий - в рамках тех или иных теорий - являются создателями не только своих книг, «они создают нечто большее: возможность и правило образования других текстов» ${ }^{1}$ ᄉ. С. Выготский в свое время отмечал: «...слово приобретает свой смысл только во фразе, сама фраза приобретает смысл только в контексте абзаџа, абзаџ - в контексте книги, книга - в контексте всего творчества автора» 2 . Опираться на контекст - значит придерживаться установившегося, принятого

\footnotetext{
${ }^{1}$ Пичугина В. К. Дискурс в педагогике: лингвистический и исторический аспекты // Историко-педагогический журнал. 2012. № 4. С. 76-86. С. 79.

${ }^{2}$ Выготский Л. С. Мышление и речь. Изд. 5, испр. М.: Лабиринт, 1999. 352 с. С. 68.
} 
в профессиональном сообшестве уровня абстракџии и использовать понятия заданного в нем семантического поля. В научных сообшествах принято считать, что контекст - самый распространенный способ устранить многозначность.

Качественной характеристикой историко-педагогических исследований является контекстуальность (обусловленность контекстом). Так, например, при изучении педагогических идей в культурном и соџиальном контексте, в котором они «возникали, развивались, транслировались, взаимодействовали, видоизменялись или прерывались, огромную роль играют: антропологический контекст, задаюший понимание роли и места образования в онтогенезе человека; религиозный контекст, влияюший на образовательные идеалы различных эпох и культур; политический контекст, задаюшй понимание политической функџии государства; экономический контекст, задающй рассмотрение образования как производительной силы общества, как важнейшего механизма воспроизводства рабочей силы и т. д.» ${ }^{1}$.

Строя новую школу - инноваџионную в технологическом отношении, новаторскую, носящую глубоко гуманистической характер по отношению к участникам педагогического проџесса, необходимо помнить величайшее культурное наследие, которое содержится в работах многих поколений зарубежных и отечественных педагогов. Можно сказать, что в этом наследии нет ни одной прогрессивной идеи, которая не вошла бы в систему современной педагогики. Историко-педагогическое знание является основой формирования современной педагогической культуры и у студентов - будущих работников системы образования ${ }^{2}$.

Современные педагогические проблемы могут быть объяснены лишь через «восхождение» к истории педагогики, обладаюшей не только безусловной самоџенностью, но и заключаюшей в себе огромный эвристический и прогностический потенџиал при решении актуальных проблем теории и практики образования.

Аргументом, подтверждающим данное положение, являются результаты контент-анализа статей, опубликованных в наџиональном спеџиализированном издании «Историко-педагогический журнал», миссия которого - не только изучение и популяризаџия педагогической культуры прошлого, но и осмысление с исторических позиџий теории и практики современного образования.

За годы существования журнала в нем опубликовано более 400 статей. Среди авторов журнала, представляюших более 50 городов, преподаватели 67 российских вузов, крупнейшие ученые, теоретики и практики образования, исследования которых во многом определяют векторы развития образования страны; учителя школ и педагоги системы дополнительного образования; государственные служащие; исследователи Украины, Белоруссии, Эстонии, США.

\footnotetext{
${ }^{1}$ Корнетов Г. Б. Педагогические идеи и учения в истории педагогики // Историко-педагогический журнал, 2015. № 2. С. 44-68. С. 49.

${ }^{2}$ Уткин А. В. Год российской истории // Историко-педагогический журнал. 2012. № 1.

C.7-11. C.10.
} 
Использование контент-анализа как вспомогательного метода позволило изучить тексты научных статей, представленных в «Историко-педагогическом журнале» в их соџиально-педагогическом и историко-педагогическим контексте, выявить обшие тенденџии, связанные с подходами к решению насушных проблем современного образования.

Изучаемые признаки текстов (содержание проблемы, причины ее возникновения, проблемообразуюший субъект(ы), степень актуальности проблемы, пути ее решения и др.) рассматривались нами как:

- определенным образом организованная совокупность ключевых понятий историко-педагогических исследований, среди которых можно назвать такие, как образование (педагогическое образование, модели образования, образование как џенность и др.); џенности; традиџии; педагогические идеи; педагогическое движение; педагогические новаџии и др. Напр.: «Педагогические феномены учительства и ученичества в доиндустриальных обществах» (Безрогов В. Г., ИПЖ, 2011, № 3); «Миссия учителя в контексте идей христианской педагогики» (Загрекова А. В. ИПЖ, 2012, № 2); «Генезис понятий «человек», «личность», «индивидуальность», «соџиальность», «общество» в отечественной педагогике (1880-1930-е гг.)» (Семенова Н. В., ИПЖ, 2012, № 4); «Наџионально-исторический контекст категории «образование» (Уманская М. В. ИПЖ, 2013, № 2); «История русского образования в контексте языческих и православных традиџий» (Колпачев В. В., Петригина В. А., ИПЖ, 2011, № 1); «Русь изначальная: истоки отечественных образовательных традиџий» (Смирнов В. И., ИПЖ, 2014, № 1) и др.;

- методологическое пространство, отражаюшее историко-генетические аспекты современной педагогической проблематики - «Некоторые неисследованные и малоисследованные проблемы педагогики и образования дореволюџионной России» (Днепров Э. Д., ИПЖ, 2013, № 4; ИПЖ, 2014, № 1-4); «Этнокультурный генезис педагогических практик» (Бим-Бад Б. М., ИПЖ, 2011, № 3); «Педагогические идеи и учения в истории педагогики» (Корнетов Г. Б., ИПЖ, 2015, № 2); «От первобытного воспитания к гуманистическому образованию (к 300-летию Ж. Ж. Руссо)» (Корнетов Г. Б., ИПЖ, 2012, № 2); «Историко-педагогическая ретроспектива педагогической реальности: антропологичность, дискурсивность, эпистемологичность» (Пичугина В. К. ИПЖ, 2012, № 4); «История педагогики как поле методологических детерминант историко-педагогического исследования» (Бобрышов С. В., ИПЖ, 2013, № 2); «Методологические проблемы историографии взаимоотношения Российской власти и общества в вопросах общего образования в XIX - нач. XX вв.» (Козлова Г. Н., Овчинников А. В., ИПЖ, 2014, № 4); «Методология историко-педагогического прогнозирования развития непрерывного педагогического образования» (Шевелев А. Н., ИПЖ, 2015, № 1); «С тановление педагогического знания в контексте педагогического наследия прошлого» (Лукаџкий М. А., ИПЖ, 2016, № 2) и др.; 
- сфера генераџии педагогических идей и опыта творческой деятельности крупнейших философов, организаторов, практиков и исследователей образования. Среди них: «А. С. Макаренко: марксизм и советский воспитательный проект 1920-1930-х годов» (Новиков С. Г. ИПЖ, 2011, № 1); «Гуманистический проект С. Т. Шаџкого : к 100-летию со дня основания колонии «Бодрая жизнь» (Романов А. А. ИПЖ, 2011, № 2); «Теоретические основания педагогики С. Френе в соџиокультурном и историко-педагогическом контексте» (Барышникова О. М., ИПЖ, 2016, № 3) «Герберт Спенсер: воспитание методом естественных последствий»; (Астафьева Е. Н., ИПЖ, 2011, № 3); «Становление и развитие Монтессори-педагогики в Беларуси» (Стражинская Н. С., Тукач В. П., ИПЖ 2014, № 3)» «Философия образования Джона Дьюи в Нидерландах» (Рогачева Е. Ю. ИПЖ, 2014, № 4) и др.;

- презентаџия событий и фактов, изучение которых восполняет пробелы в историко-педагогическом знании, напр.: «Историко-педагогические воззрения Мишеля Фуко» (Савин М. В., ИПЖ, 2012, № 3); «История становления системы дополнительного образования детей в России: начало пути» (Каргина З. А., ИПЖ, 2012, № 4); «Общеобразовательные реформы и математическое образование в средней школе России в начале XX века» (Павлидис В. Д., ИПЖ, 2013, №4); «Этико-педагогические представления о добродетельной жизни в отечественной нравоучительной литературе XVIII - первой половине XIX в.» (Макаров М. И., ИПЖ, 2014, № 2); «Российское училищное чиновничество в XIX в.» (Сахарова ᄉ. Г., Слотин В. Е., ИПЖ, 2014, № 3); «Просветительская деятельность священников-подвижников Вятско-Камского региона Стефана Пермского и Трифона Вятского» (Помелов В. Б., ИПЖ, 2016, № 2) и др.;

- демонстраџия смыслов профессионально-педагогической деятельности, отражаюших на ментальном уровне мировоззренческие установки исследователя: «Современные проблемы ментального воспитания в свете педагогических идей К. Д. Ушинского» (Чапаев Н. К., Верешагина И. П., ИПЖ, 2012, № 1); «Механизм распространения педагогической традиџии» (Юдина Н. П. ИПЖ, 2012, № 1); «Особенности духовно-нравственного становления личности в педагогике Рудольфа Штайнера» (Донгаузер Е. В., ИПЖ, 2012, № 4); «Педагогическая система Н. В. Кузьминой и педагогическое мастерство И. А. Зязюна: соотношение понятий и структур» (Остапенко А. А., ИПЖ, 2012, № 4); «Педагогические воззрения ᄉ. Н. Толстого» (Лукаџкий М. А., ИПЖ, 2013, № 3); «Осмысление проблемы учителя в советской педагогике 1918-1929 гг.» (Салов А. И. ИПЖ 2014, № 2); «Современный контекст педагогических взглядов Н. И. Пирогова» (Павлова Н. П., ИПЖ, 2014, № 4); «Актуализаџия педагогических идей К. Д. Ушинского в канун Великой Отечественной войны 1941-1945» (Заварзина А. Э. ИПЖ, 2015, № 1) и др. 
Обработка больших текстовых массивов, представленных в статьях 16 рубрик журнала, предоставляет возможность: во-первых, выявлять тенденџии изменения взглядов, позиџий путем сопоставления текстов одного автора (или ряда авторов - представителей одного направления), относящихся к разным периодам времени; во-вторых, выявлять различия, характеризуюшие содержание текстов, принадлежаших разным авторам (или авторам - последователям различных школ) путем сопоставления этих текстов.

Вместе с тем, отчетливо выражена общая закономерность авторского контента, - как результата историко-педагогического исследования, представленного научным текстом в журнале - его направленность на возможные, альтернативные пути решения насушных педагогических проблем.

2017 год богат знаменательными для истории нашей страны событиями. Одно из них - столетие Октябрьской революџии 1917 года, крупнейшего политического события $\mathrm{XX}$ века, повлиявшего на дальнейший ход всемирной истории. С советским периодом связана џелая эпоха в развитии и становлении отечественной педагогики. Педагогический потенџиал советской педагогики огромен, и сегодня настало время - без идеологической истерии и манипуляџий историческими фактами - в грамотной, корректной, взвешенной оџенке тех идей, которые возвращаются в практику современного образования новыми моделями, методиками, организаџионными формами, видами деятельности. Среди них: возрождение российского движения школьников; воспитательная работа как системообразующй фактор деятельности современной школы; юнармейское движение и военно-патриотические конкурсы; трудовое воспитание, профориентаџия и организаџия взаимодействия с базовыми предприятиями и др.

Изучение богатейшего отечественного педагогического опыта советского периода в глобальном историко-педагогическом контексте развития образования и педагогической мысли XX столетия, определение граниџ его применения в современных условиях; уточнение спеџифики рождения и особенностей реализаџии образовательных феноменов советского прошлого в историко-генетической ретроспективе являются неотъемлемой частью научной рефлексии проблем современного образования.

\section{Список литературы}

1. Выготский, ᄉ. С. Мышление и речь. Изд. 5, испр. / Л. С. Выготский - М. : Лабиринт, 1999. - 352 с.

2. Корнетов, Г. Б. Педагогические идеи и учения в истории педагогики / Г. Б. Корнетов / / Историко-педагогический журнал. - 2015. - № 2. - С. 44-68.

3. Пичугина, В. К. Дискурс в педагогике: лингвистический и исторический аспекты / В. К. Пичугина // Историко-педагогический журнал. - 2012. - № 4. - С. $76-86$.

4. Уткин, А. В. Год российской истории / А. В. Уткин // Историко-педагогический журнал. - 2012. - №1. - С. 7-11. 
Памятные даты истории образования и педагогики....13

\title{
П ПамятныЕ даты ИСТОРИИ ОБРАЗОВАНИЯ И ПЕДАГОГИКИ
}

\author{
Г. Б. Корнетов
}

\section{प्रН ЯМОс КОМЕНСКИЙ И ВОЗНИКНОВЕНИЕ ПЕДАГОГИЧЕСКОЙ НАУКИ}

УДК 37(092)(091)

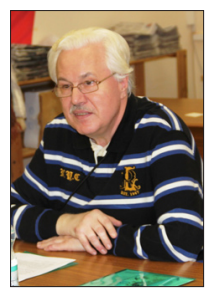

ББК 74.03(4Чех)4-8Коменский Я. А.

Ян Амос Коменский (1592-1670) - один из величайших мыслителей своего времени. Сушествует точка зрения, согласно которой Коменский считается основоположником педагогической науки.

Ключевые слова: Ян Амос Коменский; педагогическая наука; школьное образование.

\section{G. B. Kornetov}

Ian IM $_{\text {Mos COMENIUS }}$ AND THE EMERGENCE OF PEDAGOGICAL SCIENCE

Ian Amos Comenius (1592-1670) was one of the greatest thinkers of his time. There is a point of view according to which Comenius is considered the founder of pedagogical science.

Key words: Ian Amos Comenius; pedagogy; school education.

XVII столетие, подготовленное всем предшествуюшим развитием Европы, стало поворотным в истории западной џивилизаџии, в эволюџии присущих ей педагогических традиџий, особенности динамики и характер содержания которых отражали коренные сдвиги в материальной и духовной жизни западноевропейского обшества. XVII век ознаменовался распространением представлений об активном субъекте, вырвавшемся из средневековых пут и способном, развив себя, прожить ему одному свойственную жизнь. Интеллектуальная жизнь Запада все более стала определяться верой во всесилие познающего человеческого разума, способного с помошью 
истинного метода открыть законы мироздания и, используя их, обеспечить поступательное движение всех сфер человеческой жизни. Одним из величайших мыслителей XVII столетия был Ян Амос Коменский (1592-1670).

Коменский родился в Чешской Моравии в крестьянской семье, принадлежавшей к религиозной Общине чешских братьев. Чешские братья были наследниками антифеодальных демократических традиџй антикатолического реформаторского движения гуситов. В 1608 г. Коменский поступил в лучшее учебное заведение Общины - в латинскую школу в г. Пшерове. В 1611 г. он прошел обряд протестантского крешения и прибавил к своему имени второе - Амос. В 1611-1614 гг. Коменский продолжил образование сначала в Гернборнском университете в Германии, а затем в Гейдельбергском университете. В 1614 г. Коменский вернулся на родину, стал учителем, а затем и руководителем школы в Пшерове. В 1616 г. он принял сан священника. Работая в Пшерове, Коменский в 1618-1621 гг. одновременно исполнял обязанности учителя, проповедника и руководителя совета братской Общины в г. Фульнеке.

В эти годы Коменский оказался в эпиџентре событий Тридџатилетней войны. В 1620 г. армия чешских протестантов была разгромлена католическими завоевателями. Имперские войска огнем и мечом насаждали католиџизм, члены Общины чешских братьев были вынуждены скрываться в горах. В 1622 г. у Коменского от чумы умерли жена и два сына. Враги сожгли его дом, библиотеку и все рукописи. В работе «Лабиринт мира и рай сердџа» (1620-1623) Коменский нарисовал страшную картину бесчеловечного мира и воспел гимн просвещенному сердџу, способному победить зло войны и порока.

В 1628 г. австрийский император издал указ, запрещавший протестантам жить на территории Чехии. Коменский был вынужден покинуть родину и переселиться в польский город Лешно. В Лешно он активно занимался педагогической деятельностью, завершил «Великую дидактику», написал «Материнскую школу», «ОТ крытую дверь языкам», «Предвестник пансофии». В 1632 г. Коменского избрали епископом Общины чешских братьев.

В 1638 г. Коменский отказался от приглашения принять участие в реформировании школьного образования в Швеџии. В 1641 г. по приглашению английского парламента он участвовал в открытии Колледжа образованных людей в Лондоне. В 1642 г. накануне своей смерти кардинал Ришелье вел переговоры с Коменским о его участии в перестройке школьной системы Франџии. В том же году Коменский в Швеџии обсуждает проект школьной реформы и переселяется в шведскую часть Польши. В 1648 г. он возврашается в Лешно и в том же году издает «Новейший метод языков».

В 1650 г. венгерский князь Ракоџи пригласил его улучшить состояние трансильванских школ. Коменский, женившийся к этому времени в третий раз, переехал в Шарош-Патак, где прожил четыре года, разрабатывая реформу школы и пытаясь провести ее 


\section{Памятные даты истории образования и педагогики.... 15}

в жизнь. В эти годы из-под его пера выходят «О развитии природных дарований», «Об искусстве пользоваться книгами - первейшим инструментом развития природных дарованиї», «Пансофическая школа», «Законы хорошо организованной школы», «Правила поведения», «Живая типография». Он работает над иллюстрированным учебником «Мир чувственных вешей в картинках».

В 1654 г. Коменский, неудовлетворенный результатами своей реформаторской деятельности, вернулся в Лешно. В ходе военных действий между Польшей и Швеџией в 1656 г. Лешно был разрушен. В сгоревшем городе вновь погибли все рукописи Коменского. В том же году он переехал в Амстердам. В 1657 г. начинают издаваться тома «Полного собрания дидактических сочинений» Коменского. Он работает над главным трудом своей жизни - «Всеобщим советом об исправлении дел человеческих». В нем Коменский излагает грандиозный гуманистический проект реформирования современного ему обшества на основе развития образования и просвешения людей. Важнейшей составной частью «Всеобшего совета» стала «Панпедия» - теория непрерывного образования личности на основе использования закономерностей педагогического проџесса. В 1668 г. его приглашают в Лондон для изложения проекта перед членами Королевского обшества. Умер Коменский вдали от родины, в Амстердаме, в 1670 г.
На протяжении всей своей жизни Коменский активно занимался педагогической, обшественной и религиозной деятельностью. Он создал множество учебников, которые пользовались большой популярностью в Европе. Следуя религиозной традиџии христианства, Коменский видел верх человеческой образованности в благочестии (страхе Господнем) как «венџе премудрости». В духе гуманистической идеологии Возрождения образованными людьми он провозглашал «истинных людей», т. е. тех, кто человечен по своим нравам. Обрашаясь к педагогической проблематике, Коменский попытался определить антропологические основания проџесса образования и раскрыть его сушность. «Шель школ должна состоять в том, чтобы человек соответствовал своему назначению, т. е. чтобы он получил образование во всех тех пунктах, которые совершенствуют человеческую природу» ${ }^{1},-$ писал он, подчеркивая, что никто не может стать образованным без воспитания или культивирования, т. е без прилежного обучения и воспитания.

Сушествует точка зрения, согласно которой именно Я. А. Коменский был основоположником научной педагогики.

В 1975 г. Жан Пиаже (18961980), являвшийся в то время директором Международного бюро просвешения, написал статью, посвященную Я. А. Коменскому, в которой обратил особое внимание на трудности интерпретаџии его наследия, на опасность

\footnotetext{
${ }^{1}$ Коменский Я. А. Выход из школьных лабиринтов, или Дидактическая машина // Избр. пед. соч.: в 2 т. М., 1982. T. 2. С. 175.
} 
модернизаџии идей автора, жившего четыре века назад. Ж. Пиаже отмечал, что Я. А. Коменского «можно было бы... представить как предтечу эволюџионизма, генетической психологии, дидактики, основанной на знании ребенка, функџионального и международного образования, или как метафизика, который не подозревал о требованиях экспериментального исследования ни в психологии, ни даже в педагогике и подменял идейные дискуссии анализом фактов». Но, подчеркивал Ж. Пиаже, «все эти крайние суждения были бы неточными» ${ }^{1}$. Ж. Пиаже указывал, что Я. А. Коменский, «богослов, увлеченный метафизикой и пропитанный умозрительной атмосферой XVII в.», «в век, когда педагогика сводилась к простой технике или же к общим наблюдениям без каких-либо попыток создать педагогическую науку или дидактику», «первым разработал во всей полноте науку педагогику... и сделал ее сердџевиной “пансофии" ${ }^{2}$. Ж. Пиаже считал, что, «невзирая на различие в методологии, Коменского, бесспорно, можно считать одним из предтеч генетической идеи в психологии развития и основоположником прогрессивной дифференџированной дидактики» ${ }^{3}$.

По мнению Ж. Пиаже, одной из причин, не позволивших Я. А. Коменскому завершить грандиозный «Совет об исправлении дел человеческих», «был конфликт между его философско-теологической основой и тенденџиями современного Коменскому времени, направленными на развитие спеџиальных наук, в особенности метаматематической физики. На смену идеалу единого, неделимого знания, о котором мечтал Коменский, уже пришел новый идеал зарождаюшейся современной науки... Наукой своего времени он не владел и не понял причин, побуждавших его современников развивать спеџиальные науки отдельно от философии. Но в силу парадокса, поучительного с точки зрения истории наук, этот метафизик, мечтавший об интегральном знании, способствовал написанием своей “Великой дидактики” и спеџиальных трактовок созданию педагогической науки и теории дидактики как самостоятельных дисџиплин.... Это, безусловно, его главная гордость... Коменский... из тех авторов, которых не обязательно исправлять или им противоречить, чтобы их осовременить, - их идеи нужно лишь переводить и развивать... Коменский поставил ряд новых для своего века проблем: умственного развития, психологических основ дидактических методов, связи между школой и обществом, необходимости структурирования или регламентаџии программ, управления образованием, наконеј, международной организаџии научных исследований и образования. Постановка таких проблем, имеющих жизненно важное значение для чело-

\footnotetext{
${ }^{1}$ Пиаже Ж. Ян Амос Коменский (1592-1670) // Мыслители образования. В 4 т. / ред. 3. Морси. М., 1993. Т. 1. С. 167.

${ }^{2}$ Там же. С. $168,169,168$.

3 Там же. С. 172.
} 


\section{Памятные даты истории образования и педагогики....1}

вечества, остается самой большой гордостью знаменитого педагога» ${ }^{1}$.

В отечественной историко-педагогической литературе развернутый анализ роли Я. А. Коменского как основоположника педагогической науки дал Б. М. Бим-Бад в комментариях к «Великой дидактике» и «Новейшему методу языков», помешенных в первом томе двухтомного издания избранных педагогических сочинений великого чеха, вышедших в 1982 г. в серии «Педагогическая библиотека».

«Великая дидактика», которую Б. М. Бим-Бад называет главным систематическим сводом педагогической науки Я. А. Коменского, фундаментом науки о воспитании, образовании, обучении, была издана на чешском языке в 1627 и 1632 гг., а на латинском языке - в 1657 г. Связывая с ее появлением точку отсчета начала педагогической науки, Б. М. Бим-Бад пишет: «Дидактика, школоведение, теория воспитания и педагогическая психология впервые в истории педагогической мысли обрели в «Великой дидактике» свой предмет и составили в своей совокупности особую науку, прежде не сушествовавшую в качестве спеџиальной области знания. Эта наука представлена здесь в составе всех своих важнейших проблем: џели, задачи, содержание, психологические факторы и предпосылки, методы и организаџионные формы образования личности, становления и совершенствования способностей. Решение этих проблем приобрело статус всеобщего и необходимого, достоверного и доказательного знания, конституирующего законы и, в свою очередь, основывающегося на их непреложности. «Великая дидактика» - грандиозная система, џелостная теория вкупе с ее обоснованием («философией воспитания»)... Новаторство Коменского беспреџедентно: в «Великой дидактике» он не только систематизировал педагогику, не только синтезировал в соответствии со всей пансофической конџепџией лучшее из педагогической мысли прошлого - он впервые решил ряд вопросов, бывших предметом вековых, эпохальных споров; он впервые поставил ряд важнейших вопросов, впервые дал теоретическое обоснование педагогических норм; он создал теорию воспитательного искусства» ${ }^{2}$.

В комментариях к «Аналитической дидактике», являюшейся десятой главой «Новейшего метода языков» (предположительно эта работа написана Я. А. Коменским в 1846-1848 гг.) Б. М. Бим-Бад отмечает, что в этой работе чешский педагог отказывается от использованного им в «Великой дидактике» метода доказательства педагогических и иных постулатов и правил на основе аналогий (сравнений) с природными и производственными пројессами.

По словам Б. М. Бим-Бада, в «Новейшем методе языков» Я. А. Коменский дедуџирует «принџипы и правила дидактики из анализа основополагающих категорий и конкретных понятий, составляющих костяк педа-

\footnotetext{
Там же. С. 180, 181, 182.

2 [Бим-Бад Б. М. Комментарий] Великая дидактика // Коменский Я. А. Избр. пед. соч. : в 2 т. M., 1982. T. 1. С. 626.
} 
гогической науки. Метод дедуктивно-аналитический был вполне в духе времени, точнее - в духе Р. Декарта, отводившего исключительную роль в познании дедукџии как форме доказательства и изложения. За различием дедукџии и индукџии у Декарта стояло не только различение двух способов познания, но и противопоставление того, что заключено в природе и способе организаџии знания, и того, что заключено в природе самого познаюшего субъекта. Противопоставление субъекта и объекта познания знаменовало собой утверждение современной, Нового времени, философии как теории познания. Коменский завершил «Великую дидактику» до выхода в свет главных новаторских сочинений Декарта..., приведших к повороту теории познания от сенсуалистического эмпиризма к гносеологическому раџионализму. Коменский, усмотрев в теории познания Декарта возможность обоснования педагогики путем дедуктивным, путем выведения ее из постулатов, из основоположений, из аксиом, перерабатывал свою дидактику (собственно, педагогику). Однако педагогическое значение «Аналитической дидактики» определяется отнюдь не только ее методом, а содержанием, действительным внут ренним строением системы ее общетеоретических и методологических идей. Учебный проџесс трактуется и исследуется здесь Коменским как спеџи- фическая форма, вид познавательного пројесса; причем законы обучения предстают модификаџией законов познания и мышления как таковых. Отсюда - точные и обстоятельные формулировки законов воспитываюшего обучения, ведушего учашихся от простого знания (низшая ступень постижения сущности мира) к познанию (к постижению сущности вещей и к творческому применению знаний на практике). Коменский едва ли не первым в истории педагогической мысли психологизировал педагогику: его теоретическая и нормативная дидактика базируется на тонких и точных психологических наблюдениях» 1 .

С изложенной точкой зрения в корне не согласен В. В. Платонов. По его мнению, превращение педагогики в науку произошло значительно позже. Он, в частности, по этому поводу пишет: «Можно ли, например, в сколько-нибудь серьезном смысле считать Я. А. Коменского «основоположником научной педагогики?»... Возможно ли хотя бы начало становления «научной педагогики» во времена Коменского (середина XVII в.) до становления первой опытной науки? Т. е., до трактата Ньютона $(1687)^{2}$, завершающего формирование первой такой науки, открывающей становление подобных наук и научного мировоззрения?... Значение педагогики Коменского состояло в содержательном отборе, системати-

${ }^{1}$ [Бим-Бад Б. М. Комментарий] Новейший метод языков. Глава Х. Аналитическая дидактика // Коменский Я. А. Избр. пед. соч. Т. 1. С. 645-646.

${ }^{2}$ Прим. авт.: В. В. Платонов имеет в виду книгу И. Ньютона «Математические начала натуральной философии». 
Памятные даты истории образования и педагогики....19

заџии и дополнении эмпирических реџептурных правил и принџипов педагогической практики того времени. С точки зрения методологии, подобные эмпирические генерализаџии, однако, не составляли научной теории, а оставались в пределах того, что можно назвать “практической инженерией $\square$ или же технологией образования, опиравшейся на воображение, руководимое здравым смыслом и опытом педагогов... Технологические изобретения, конечно, могут составлять какие-то эмпирические предпосылки науки, но их не следует отождествлять с обоснованием научной теории, опирающейся на данные џелого ряда наук, с которыми связано образование... Религией и теологией у Коменуса связана далекая от науки мифологическая картина мира, из которой «выводилась «џель образования»- «спасение», а также учебный план; из трактовки образа человека и знания с позиџий первородного греха выводилась средневековая практика воспитания посредством «страха божия», методов «бадейной педагогики» и индоктринаџии, слепая вера и направленность на «типографирование» конформистов, не говоря уже о консервативном утопизме его реформаторских устремлений, направленных на укрепление примата веры в период роста раџионализма... С тановление науки в области образовательного знания имеет џелый ряд предпосылок. Наиболее фундамен- тальной соџиальной предпосылкой является поворот обшества от застоя позднего Средневековья в сторону развития и, соответственно, сдвиг на наиболее общем, философско-мировоззренческом уровне культуры: от религии, охранявшей застой, к утверждению научного метода, позволяющего искать новые пути организаџии обшества и обеспечения жизненных потребностей людей в эмпирически наличном мире при посредстве эмпирически наличного сознания и практики. Особое значение для становления научного подхода к образованию имеют многосторонние взаимодействия образовательных знаний с множеством смежных наук»1.

Далее В. В. Платонов продолжает: «В образовательном знании два принџипиальных сдвига в сторону науки произошли во второй половине XVIII в., когда Запад вступил в век революџий - индустриальной, соџиальной, политической: во-первых, возрастающее участие правительства в обеспечении и организаџии образования, в отличие от просто принятия декретов, и, во-вторых, новые конџепџии человека и общества, которые обеспечивали альтернативы для предположений о возможностях будущего развития... Новый - научный - подход к образовательному теоретизированию тоже был в проџессе развития как часть общего феномена Просвещения, он сушественно зависел от мышления

\footnotetext{
${ }^{1}$ Платонов В. В. Европейское образование эпохи модерна. Проблемы теории и истории по материалам книги Боуэна // Боуэн Д. История западного образования. Западная Европа эпохи модерна и Новый Свет : пер. с англ. и вступ. статья В. В. Платонова. М., 2013. [Электронный ресурс]. Режим доступа: http://www.gumer.info/bibliotek Buks /Pedagog/Bowen/01.php
} 
Фрэнсиса Бэкона, Джона Локка и Ж.-Ж. Руссо» (а также Монтескье, Вольтера, Дидро и др.)»1.

Очевидно, что ответ на вопрос о том, был ли Коменский основоположником педагогической науки, будет зависеть от того, каким образом понята сама наука.

В своих произведениях, опираясь на достижения предшественников, Коменский детально разработал теорию организаџии образования школьников. Утверждая, что искусно обучать может лишь тот, кто знает надежные приемы хорошего обучения и на их основании способен вести учашихся к знанию вешей быстро, приятно и основательно, он подчеркивал, что учитель должен быть не только сведушим в обучении, но и быть способным и желаюшим учить. Ученик же, по мнению Коменского, должен не только быть в состоянии учиться, но хотеть и этого, активно участвовать в обучении: «Того, в ком нет желания к учению, будешь учить напрасно, если ты в нем в первую очередь не возбудишь стремления к учению. (Это, собственно, значит добиться того, чтобы он желал знать, чтобы он принял участие в обучении со свежими чувствами, чтобы он оставил все в стороне и сосредоточил на нем свое внимание. Я тут же скажу, как это происходит.)» ${ }^{2}$.

Разрабатываемая Коменским педагогическая проблематика стала џентральной темой его философии, направленной на поиск путей, спо- собных привести человека к его сущности. Главной философской идеей Коменского была идея кафоличности (всеобщности), направленная на восстановление общечеловеческой истины, которая, по его мнению, была искажена римской католической џерковью. Это означало полноту охвата материальной и духовной действительности (всё); полноту охвата человеческого субъекта во всей полноте человечности и совершенства (все); полноту охвата познаний, умений, интуиџий всеобъемлющего субъекта, действуюшего в совокупном мире (всячески). Реформаторский проект Коменского был неразрывно связан, с одной стороны, с его христианским мировоззрением, с верой во всеблагого Творџа и достижимостью спасения, обешанного в Откровении, с другой стороны, с его просветительскими установками, с убежденностью во всесилии просвешения, развиваюшего и совершенствуюшего духовные способности каждого человека, которые позволяют преобразовывать ему и свою жизнь, и жизнь общества на основе преодоления негативных черт окружаюшего людей соџиального мира.

Стремясь к переустройству мира на основах справедливости, гуманности, всеобшего благоденствия, Коменский создал грандиозный труд «Всеобший совет об исправлении дел человеческих» (в другом переводе - «Вселенский совет об исправлении человеческих дел»), в котором он наметил пути реформирования обше-

\footnotetext{
${ }^{1}$ Там же.

${ }^{2}$ Коменский Я. А. Новейший метод языков // Там же. Т. 1. С. 534.
} 
Памятные даты истории образования и педагогики...21

ства в соответствии с выдвигаемыми им принџипами. Реализаџию своих идей он связывал с установлением всеобщего мира в истерзанной рели- гиозными, соџиальными и политическими распрями Европе, а также распространением всеобщего школьного образования.

\section{Список литературы}

1. Астафьева, Е. Н. Восхождение к истории педагогики / Е. Н. Астафьева // Academia: Педагогический журнал Подмосковья. - 2015. - № 2. C. 57-63.

2. Астафьева, Е. Н. Познавательный и образовательный потенџиал истории педагогики / Е. Н. Астафьева / / Academia: Педагогический журнал Подмосковья. - 2016. - № 2. - C. 59-62.

3. Астафьева, Е. Н. Постигая историю педагогики. К итогам Третьего Наџионального форума российских историков педагогики / Е. Н. Астафьева // Academia: Педагогический журнал Подмосковья. - 2015. - № 2. C. 59-62.

4. Бим-Бад, Б. М. История и теория педагогики. Очерки: учебн. пособ. для вузов. 2-е изд., испр. и доп. / Б. М. БимБад. - М. : Юрайт, 2016. - 272 с.

5. Коменский, Я. А. Избранные педагогические сочинения: в 2 т. / Я. А. Коменский. - М. : Педагогика, 1982. - Т. 1. - 656 с.; Т. 2. - 576 с.

6. Корнетов, Г. Б. Историко-педагогический контекст теории и практики современного образования: монография / Г. Б. Корнетов. - М. : АСОУ, 2016. -172 c.

7. Корнетов, Г. Б. Основной вопрос педагогики как проблема конџептуализаџии педагогического знания / Г. Б. Корнетов // Историко-педагогический журнал. - 2016. -№ 3. - С. 28-37.
8. Корнетов, Г. Б. Педагогическая мысль как феномен развития педагогической науки / Г. Б. Корнетов / / Историкопедагогический журнал. - 2016. - № 1. С. 65-89.

9. Корнетов, Г. Б. Педагогика: теория и история. 3-е изд., перер., доп. / Г. Б. Корнетов. - М. : АСОУ, 2016. 472 c.

10. Корнетов, Г. Б. Понимание педагогики как истории педагогики / Г. Б. Корнетов // Психолого-педагогический поиск. - 2013. - № 4 (28). С. 123-134.

11. Корнетов, Г. Б. Теория истории педагогики: монография / Г. Б. Корнетов. M. : ACOY, 2013. - 460 c.

12. Пиаже, Ж. Ян Амос Коменский / Ж. Пиаже // Мыслители образования / ред. 3. Морси. - Т. 1. - М. : ЮНЕСКО, Прогресс, 1994. C. 167-190.

13. Платонов, В. В. Европейское образование эпохи модерна. Проблемы теории и истории по материалам книги Боуэна / В.В.Платонов // Боуэн Д. История западного образования. Западная Европа эпохи модерна и Новый Свет : пер. с англ. и вступ. статья В. В. Платонова. М., 2013. [Электронный ресурс]. Режим доступа: http://www.gumer. info/bibliotek Buks/Pedagog/Bowen/ 


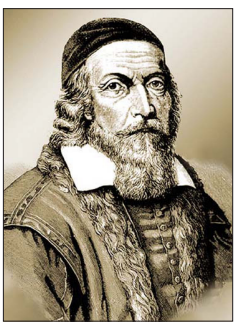

\section{Ян Амос Коменский}

\section{МатетиКА,}

то есть

НАУКА УЧЕНИЯ ${ }^{1}$

Ян Амос Коменский (1592-1670) - великий чешский мыслитель-гуманист, основоположник педагогической науки. Деятельность учения сопровождает деятельность преподавания, и работе учителя соответствует работа учеников. Теоретически и практически это впервые показал Ян Амос Коменский, развивавший МАТЕТИКУ, науку учения, наряду с ДИДАКТИКОЙ, наукой преподавания.

Матетика от греч. mathesis - изучение, познание. Матетика - это наука о џелеполагании, которая доказывает необходимость начального этапа любой деятельности с обсуждения конечных џелей, т. е. предполагаемых плодов деятельности. Задачи матетики - изучение и разработка методики приобретения знаний из той или иной предметной области.

Џелеполагание в обучении - это установление учениками и учителем џелей и задач обучения на определенных его этапах. В зависимости от образовательных парадигм и дидактических систем в числе образовательных џелей могут быть - усвоение знаний, умений и навыков, развитие способностей, формирование компетенџий, творческой самореализаџии, самоопределения, профориентаџии и др. Имеют место и так называемые формальные џели: сдать әкзамен, поступить в вуз и т. п.

Џелеполагание необходимо для проектирования образовательных действий учашихся и связано с внешним соџиальным заказом, образовательными стандартами, со спеџификой внутренних условий обучения (уровнем развития детей, мотивами их учения, особенностями изучаемой темы, имеющимися средствами обучения, педагогическими воззрениями учителя и др.). Џелеполагание проходит через весь проџесс продуктивного образования, выполняя в нем функџии мотиваџии деятельности учаџихся, структурной стабилизаџии учебного проџесса, диагностики результатов обучения. Оно определяет структурную основу программ деятельности не только ученика и учителя, но и всей школы, позволяя выявить адекватную технологию обучения и систему критериев оџенки получаемых результатов.

Трактат Коменского «Матетика, то есть наука учения» недавно был переведен на русский язык под редакцией А. ᄉ. Семёнова².

\footnotetext{
${ }^{1}$ Публикация Г. Б. Корнетова

2 Фрагменты «Матетики» публикуется по: Коменский Я. А. Матетика, то есть наука учения // Историко-педагогический ежегодник. 2017 год / гл. ред. Г. Б. Корнетов. - М. : АСОУ, 2017. - C. 136-164.
} 


\section{Памятные даты истории образования и педагогики....23}

1. МАТЕТИКА - это умение <наука, искусство, техника > учиться.

2. Учиться - значит приобретать знание вешей, познавать веши.

[Три ступени знания]

3. Знать вешь - значит держать ее в своем сознании, что включает:

* Знание, что вешь есть.

* Знание содержания, смысла веши.

* Знание назначения, применения веши.

\{Первое называется замечать или просто знать; второе - понимать; третье - уметь пользоваться\}.

4. Знать, что нечто есть, сушествует - это начальная ступень знания (это лишь знакомство с вешью).

5. Знать смысл веши, понимать в силу чего она сушествует, - это полная ступень знания, его сердџевина. Это - понимание, из каких частей состоит вешь, как части взаимодействуют друг с другом и образуют Џелое.

6. Знать, как использовать вешь, - высшая ступень знания, его венеџ. Лишь мудреџу свойственно употреблять вешь во всей полноте и не допускать неправильного ее употребления.

NB. Есть три ступени знания. 1. Эмпирическая. 2. Эпистемическая. 3. Эвристическая. Сначала мы знаем, что-то из опыта; затем постигаем это через причины; наконеџ - понимаем следствия. Пример первого: если кто-либо учится измерять расстояние между двумя местами с помошью диоптра и у него все время получается один и тот же результат, хотя он и не понимает, почему все происходит именно так. Пример второго - если кто-то может показать основания измерения расстояний издали по шестой книге Евклида. Пример третьего - если кто-то может решать задачи, ранее не решенные, находить новые постановки задач и открывать новые правила. Ступень познания, которую называют согласием на веру, при которой человек, не понимая вешей, присоединяется к авторитету наставника, должна быть отброшена. Ей нет места в изучении раџиональной философии, она недостойна человеческого разума и бесполезна для подлинного продвижения в учении.

Поризм $^{1}$

Следовательно, никогда не бывает достаточно только знать, что что-то есть. Должно всегда искать ясного понимания смысла этой веши; и этого не довольно, нужно дойти до ее употребления. Или

- Нет ничего, что невозможно было бы узнать.

- Зная что-то, должно это понимать.

- Понимая что-то, должно уметь это использовать.

\footnotetext{
${ }^{1}$ Поризм (греч. porizein - делать выводы) - заключение, выведенное из предыдущего, уже доказанного положения. Пори́зм - утверждение, сформулированное в ходе решения какойлибо задачи, которое по содержанию своему охватывает намного более широкий круг явлений, нежели тот, к которому эта задача относилась (Прим. Г. Б. Корнетова).
} 


\section{4 …………...Историко-педагогический журнал, № 1, 2017}

Знание веши заключается в ее восприятии чувствами.

Понимание веши заключается в знании ее подлинного устройства, составных частей и их отношений друг с другом.

Умение использовать вешь выявляется, когда показываешь, как ее применение позволяет достичь изначально установленной џели. И тогда наступит время отдыха, конеџ возврашается к началу, и первое осушествится намерением, а последнее - исполнением.

\section{[Источники и качества знания и учения]}

7. Желая найти что-либо, учашийся обрашается в своих поисках то к изучаемой веши, то к своему уму, то к чужому.

\section{Поризм}

Ты, следовательно,

* чтобы знать, учись. Чтобы узнать быстро - учись быстро; чтобы знать много - учись многому; чтобы знать правильно, учись правильно;

* учась, учись глубоко; чтобы о тебе можно было сказать, что не столько ты учился, сколько научился и выучился, т. е. знаешь. Лучше ведь, чтобы тебя называли умным, опытным, мудрым, нежели много учившимся. Это очевидно в ремесле, где обрашают внимание не на то, сколько кто жил с мастером или как долго в состоянии рассуждать о его изделиях, но какие изделия он создает сам;

* чтобы учиться глубоко, учись с любовью. Редко бывает так, чтобы работа с охотой оказалась напрасной;

* если чего не знаешь, поспеши узнать: либо думая сам, либо от других, либо из наблюдений - если возможно, этот способ - самый лучший.

8. Венеџ же умения учиться - учиться надежно, быстро и приятно. Надежно, чтобы плод учения (знание), не оставлял места заблуждениям и сомнениям, но чтобы все держать в памяти точно и прочно. Быстро, не тратя много времени на изучение одной какой-либо веши, освобождая его для занятия другими. Приятно, без тошноты и отврашения, ничего не делая против воли, учась не в тягость, а в радость.

\section{[Три средства учения. Их качества и использование]}

9. Есть три Средства учения: Чувства, Рассудок, Вера: Чувства верные, Рассудок здравый, Вера предусмотрительная.

Мы познаем веши либо по ним самим, воспринимая их чувством; либо работая рассудком; либо с помошью других, получая их свидетельства и соображения. Разниџа между этими способами в том, что познание с помоџью других, заимствование готовых плодов, сокрашает время; самостоятельное рассуждение, разработка золотые жилы собственного ума дает более надежный плод; рассмотрение самих вешей дает наиболее верный результат. 


\section{Памятные даты истории образования и педагогики...25}

Чувства нужны нам для непосредственного восприятия ясных вещей.

Рассудок - для исследования вешей, непосредственно отсутствующих, по их следам, а также для проверки свидетельств чувств.

Вера - для познания тех вещей, которые недоступны для чувств и рассудка, и через свидетельства других.

Должно, однако же, следить, чтобы чувства были верными, чтобы они схватывали свои предметы такими, каковы они суть сами по себе, без искажений. Нужен здравый рассудок для правильного образования душевных восприятий, суждение о понятых вешах необходимо выносить обосновано, одно из другого выводить последовательно и в силу необходимости. Вера должна быть предусмотрительной, чтобы, поверив легко, мы не обманулись.

\section{Поризм}

1. Следовательно, учение состоит в том, чтобы со всей тщательностью обрашать ум к вещам, рассуждать и принимать чужие проверенные знания.

2. Для учения не приспособлены те, кто либо по вине природы, либо по случайности, либо в силу собственного порока:

* Лишены одного или нескольких благородных чувств.

* Неспособны к должному употреблению ума.

* Легковерны ко всему без разбора; либо ничего не принимают на веру из страха быть обманутыми, и не умеют избрать средний путь и тем паче придерживаться его.

10. Эти три Средства учения позволяют нам, при их должном употреблении, узнать вообще все, о чем Господь захотел, чтоб мы это знали, и выставил на обозрение на своих позорищах.

И, действительно, для восприятия вещей в Мире нам дан особый орган, Чувства, внешние и внутренние. Для охоты на всеобшие идеи и правила для этих отдельных вещей в области умопостигаемого нам дан особый орган взвешиваюший, что может или не может быть, и почему, и каким образом. Поскольку очень много такого, что сушествует вне пределов наших чувств и нашего собственного разумения, как то, что Бог дал нам в откровении через слово, или изо дня в день раскрывается нам людьми, - для восприятия этих вещей нам дан инструмент: Вера.

\section{[Возможность постижения всего]}

Следовательно, проходя все вещи по отдельности Чувствами, всеобщие категории - Рассудком и все, что нам отрывается, Верой, что мы можем оставить такого, что было бы от нас скрыто?

Затем, есть три сущности, с которыми человеку приходится сталкиваться в течение всей его жизни: мир, полный вещей, сами люди и Бог, начальствующий над миром и над людьми. Но для того, чтобы установить общение со всеми ими и 


\section{6 …………... Историко-педагогический журнал, № 1, 2017}

способствовать ему, прежде всего, служат - и достаточны - три вышеуказанных средства. А именно: чувства - чтобы использовать в нашем общении с вещами; рассудок - с людьми; вера - с Богом, хотя и тут, и здесь, и там осушествляется взаимное подспорье. С тало быть, мы располагаем достаточными средствами.

Поризм

Следовательно, никто не может возлагать на другого вину в своем невежестве, а только на себя самого, поскольку средства избавиться от невежества наличествуют в изобилии, а он лишь не умеет или не может их применить.

\section{[Различие в надежности трех Средств]}

11. Эти три средства, достаточные для просвещения умов, созданы божественным образом, они, однако же, отличаются друг от друга степенью ясности и надежности, как лучи света в очах наших.

Как свет проникает в глаз с помошью луча прямого, отраженного и преломленного, так в нас проникает и свет знания.

* Через саму вещь в ее, открытой чувству, полноте.

* Через отражение вещи в зеркале. Это происходит, когда мы узнаем вещь по другой, ей подобной - сюда относятся параболы, апологи, метафоры. Это бывает и когда мы узнаем вешь по какой-либо ее части, которая позволяет догадываться о џелом; если вещь и не предстает перед нами џеликом, то, по крайней мере, нам даны ее причина, или воздействие, или субстанџия, или акџиденџия, или след, или какой угодно признак. И это представлено уму в последовательности, благодаря которой, по познанной части вещи, можно было бы судить о других частях или обо всей вещи в џелом.

* И наконеџ, посредством свидетельств других можно судить о вещи, которая совершенно отсутствует и подлежит восприятию одной только верой. Здесь воистину в разум проникает преломленный луч: ибо проходит через двойную среду: через дым чужого мнения и облако слов, высказанных так-то и так-то. Следовательно, в этом случае мы изучаем или преподаем не самое вещь в прямом смысле слова, но то, что думает или свидетельствует об этой вещи тот или иной; истинно ли это или ложно, надлежит изучить или преподать из другого источника. 


\section{А. Н. Шевелев ДЕМИДОВСКИЕ УЧЕБНЫЕ ЗАВЕДЕНИЯ ДОРЕВОЛЮЦИОННОГО ПЕТЕРБУРГА (к 170-летию со дня основания)}

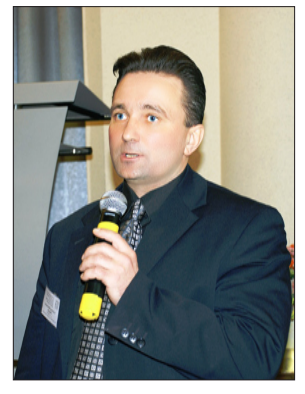

УДК 377(091)(470-25)Спб"18"

ББК 74.03(2-2Спб)5-4

Статья посвящена истории Демидовских учебных заведений дореволюционного Петербурга, которым исполняется в 2017 году 170 лет с момента основания. Образовательный комплекс этих школ сочетает общеобразовательные и профессиональные учебные заведения. Демидовский дом включал в себя детский приют, женскую гимназию, женские профессиональные школы для подготовки домашней прислуги, спещиалистов по швейному, шляпному, цветочному делу, коммерческому счетоводству, педагогов иностранных языков.

Ключевые слова: Демидовские учебные заведения; Анатолий Николаевич Демидов; петербургская дореволюџионная школа; традиџия создания образовательных комплексов; традищии благотворительности в образовании.

\section{A. N. Shevelyov}

\section{DeMidov EDUCATIONAL INSTITUTIONS IN PRE-REVOLUTIONARY PETERSBURG (by the $170^{\text {th }}$ anniversary of their foundation)}

The article is devoted to the history of Demidov educational institutions in pre-revolutionary St. Petersburg. They will celebrate 170 $^{\text {th }}$ anniversary in 2017. The curriculum of these schools combines general education and vocational schools. Demidov house included a children's shelter, women's gymnasium, women's vocational schools for training domestic servants, specialists in sewing, hat, flower business, commercial bookkeeping, and foreign language teachers.

Key words: Demidov educational institutions; Anatoly Demidov; prerevolutionary St. Petersburg school; a tradition of creating educational systems; a tradition of charity in education. 
Каждый, кто посещает сегодня новый конџертный зал знаменитого Мариинского театра в Петербурге, обратит внимание на роскошный сад, который составляет антураж этой сџены. На территории сада располагается ныне Академия физической культуры им. П. Ф. Лесгафта, один из наиболее известных џентров подготовки спортивных кадров России. Гуляя по ее территории, все обрашают внимание на великолепие старинных зданий Академии, особенно здания дворџового типа по адресу Мойка, 108. И только узкому кругу историков известно, что до революџии в нынешних зданиях Академии располагались Демидовские учебные заведения.

Демидовские учебные заведения в Петербурге к 1917 году представляли огромный и џелостный образовательный комплекс. Он включал женскую гимназию с пансионом, женское коммерческое училище, женскую профессиональную школу рукоделия, высшие женские педагогические курсы иностранных языков (франџузского и немеџкого), сиротский воспитательный дом для малолетних детей служаших Дворџового ведомства. Таким образом, история Демидовских учебных заведений представляет эволюџию от начальной профессиональной школы прислуги для императорского двора до средних и высших женских школ, сочетавших первоклассное для своего времени общее и профессиональное образование в рамках единого учебного заведения. Кроме того, имен- но здесь был организован первый в России общественный детский сад временного пребывания детей, первый в России комиссионный магазин, где продавались работы нуждавшихся женшин, первая народная столовая для бедняков столиџы. Поэтому Демидовские учебные заведения были не просто объединением разных школ, но и учреждений соџиальной поддержки и культурного развития взрослого населения столиџы.

Об этом уникальном соџиальнопедагогическом комплексе практически ничего не известно современным историкам педагогики и образования. Наиболее џенным источником информаџии по истории Демидовских учебных заведений дореволюџионного Петербурга является рукопись неизданной монографии Натальи Павловны Колпаковой (1902-1994), советского музыкального фольклориста, доктора филологических наук, выпускниџы Демидовской женской гимназии 1919 года и первого председателя ее ученического комитета. Рукопись ее монографии «Мойка, 108: История Демидовских учебных заведений в Санкт-Петербурге. 1834 - 1919 гг.», датированная 1958 годом и включающая 280 страниџ машинописного текста, хранится ныне в Кабинете рукописей Российского государственного института истории искусств (знаменитого Зубовского института), в котором Наталья Павловна работала всю жизнь ${ }^{1}$. Рукопись состоит из трех частей:

\footnotetext{
${ }^{1}$ Колпакова Н. П. Мойка, 108: История Демидовских учебных заведений в Санкт-Петербурге. 1834-1919 гг. (машинописная рукопись, 1958) // РГИИИ, Кабинет рукописей, ф.112, оп.2, д.9., лл.1-2.
} 
Памятные даты истории образования и педагогики...29

- очерка по истории Демидовских учебных заведений в период 18341909 годов;

- истории Демидовской женской гимназии, составленной на основе имевшихся в распоряжении автора архивных и мемуарных свидетельств за период 1909-1914 гг;

- текста на основе личного дневника Н. П. Колпаковой, характеризующего период ее обучения в гимназии в 1914-1919 гг.

Наряду с рукописью фонд Н. П. Колпаковой включает:

- машинописные тексты докладов Н. П. Колпаковой в Музее истории Ленинграда (25 декабря 1964) и в школе № 236 (15 сентября 1965 года) - исторической правопреемниџе Демидовской женской гимназии, располагавшейся в здании на Мойке, 108 до 1980 года. Здесь же ее письма в редакџию газеты «Аенинградская правда», обрашения в АПН СССР, в Ленинградский фонд культуры (1984 г.), Д. С. Лихачеву (26 апреля 1992). Н. П. Колпакова приглашалась школой № 236 как ее бывшая выпускниџа и использовала эти встречи для сбора мемуарных свидетельств по истории школы в 1920-1930-е годы. В фонде имеются соответствующие материалы;

- два альбома иллюстративных материалов (около 300 фотографий и зарисовок Демидовского дома, сада, внутренних помещений, формы одеж- ды, портреты учениџ, педагогов и административных лиј) ${ }^{1}$.

Таким образом, история петербургских Демидовских учебных заведений стала для Н. П. Колпаковой самостоятельным направлением ее научных исследований, которым она занималась всю научную жизнь, начав работать над книгой еще в сталинские годы, когда заниматься этой темой было небезопасно. Это не просто единственное сегодня исследование о Демидовских учебных заведениях (далее - ДУЗ) в Петербурге, но и памятник ленинградскому школьному краеведению. Активность творчества Натальи Павловны по данной теме явно связана с ее переходом в пенсионный возраст и хрущевской оттепелью, возвратившей в культурную жизнь Ленинграда краеведческие исследования дореволюџионного прошлого. Причины, почему книга так и не была опубликована, остаются и сегодня неясными. Скорее всего, они кроются в феномене советского бюрократизма и постсоветских экономических сложностях. Поэтому рукопись книги Н. П. Колпаковой по-прежнему ждет своего издателя.

Наряду с этим, главным источником информаџии и дореволюџионными изданиями в статье были использованы материалы публикаџии Н. В. Колышниџиной, представляюшей единственное опубликованное исследование по данной теме 2 . Задачей

${ }^{1}$ РГИИИ, Кабинет рукописей, ф.112, дд.60-63, ед. хр. 1-301.

${ }^{2}$ Кольишницина Н. В. Основные этапы развития Демидовского учебно-воспитательного заведения по документам ЦГИА СПб (1836-1917 гг.) // Беспризорность и безнадзорность в России. История и современность: Сборник материалов научно-практической конференции 28 октября 2008 года, Санкт-Петербург. СПб., 2008. С. 138-146. С. 141. 
статьи является первичный историко-педагогический анализ эволюџии педагогических принџипов, методов и результатов учебно-воспитательной работы Демидовских учебных заведений, изменений в управлении ими, в их школьной политике, отражавшей эволюџию соџиальной базы учащихся.

Накопленные в XVIII веке династией горнозаводчиков, металлургов и оружейников богатства, которые уже к середине столетия оџенивались в баснословную сумму почти в 3 млн. рублей, стали материальной основой их дальнейшей благотворительной деятельности. Уже в екатерининскую эпоху Прокофий Акинфиевич Демидов (внук основателя династии) жерт вовал огромные суммы на Московский университет и коммерческое училище. Одни Демидовы покровительствовали науке и образованию; другие - поощряли таланты в искусстве; третьи - помогали бедным. Не случайно эта активная благотворительная деятельность оставила в истории достойную память всей фамилии Демидовых и стала основой для организаџии международного Демидовского движения и Международного Демидовского Фонда.

Анатолий Николаевич Демидов (правнук основателя династии), родившийся в 1812 году, в 1833 году получил, достигнув совершеннолетия, право распоряжаться своим состоянием. Создание Демидовского Дома призрения трудящихся было одним из первых его благотворений. Воспитанный за граниџей, А. Н. Демидов по возвращении в Петербург был поражен огромным количеством просителей-бедняков, обрашавшихся к нему за помошью. За граниџей он познакомился с работными домами для бедноты и общежитиями при них, задумав устроить подобное и в Петербурге. В ходе спеџиальной поездки А. Н. Демидов изучил систему благотворительных учреждений Германии и Франџии. Бывший двореџ $Г$. А. Потемкина на Мойке был выбран А. Н. Демидовым не случайно. Дом призрения трудяшихся не мыслился им как богадельня, он должен был вселять надежду, сюда должны были приходить те, кто своим трудом, получив помешение, инструменты, материалы и питание, рассчитывал выйти из нужды. Изготовленные изделия планировалось продавать в пользу самих рабочих. Идея нашла поддержку у императриџы Александры Фредоровны (супруги Николая I), которая приняла новое заведение под свое покровительство, а А. Н. Демидов был назначен потомственным почетным его попечителем. Демидовский дом призрения трудящихся был открыт 19 марта 1833 года.

История детских учебно-воспитательных учреждений при Демидовском доме призрения трудяшихся разбивается на несколько периодов. Первое появление там детей было почти случайным. У многих женшин, приходивших на дневные работы, были маленькие дети, которых нельзя было оставлять без надзора, женџины стали приносить детей с собой. Вскоре их оказалось так много, что пришлось устроить для них особое дневное детское убежище с необхо- 


\section{Памятные даты истории образования и педагогики....31}

димым инвентарем. Приходившие на работу женщины по очереди дежурили в убежище. Но дети плохо переносили дорогу до Демидовского дома, простужались. Поэтому было решено впервые в России открыть спеџиальные детские комнаты по европейскому образцу в мае 1837 года для детей от 3 до 7 лет. К этому начинанию сочувственно отнеслась петербургская аристократия, новые пожертвования позволили открыть еше четыре аналогичных приюта: Василеостровский, Александро-Невский, Жуковский и Лавальский (по имени основных благотворителей).

Одновременно, в 1837 году открылась и школа для детей от 7 до 12 лет, приходивших в Демидовский дом вместе с матерями. Детей в ней обучали чтению, письму, счету и Закону Божьему, пению и гимнастике. Дети получали форму, обувь, питание, для них организовывались прогулки и послеобеденный отдых. Тогда же при школе открылся интернат с мужским и женским отделениями с общим количеством в 100 пансионеров. Известна роль ВЧК - ГПУ в борьбе с детской беспризорностью на заре советской эпохи. Но мало кто знает, что попечителем школы при Демидовском доме стал небезызвестный А. Х. Бенкендорф, шеф корпуса жандармов и начальник знаменитого III отделения. Но основными педагогами школы были ее первый директор А. Н. Турчанинов и главная надзирательниџа А. А. Хвостова. Дети сами убирали свои комнаты, мальчики овладевали переплетным мастерством, девочки рукоделиями. С 1838 года от совмес- тного обучения мальчиков и девочек отказались, и школа при Демидовском доме призрения трудяшихся стала исключительно женской.

Девочки могли теперь учиться здесь с 10 до 18-ти лет. Школа готовила квалифиџированных горничных, поэтому получила наименование «камер-юнгферской». В 1843 году в ней были открыты малолетнее отделение и приготовительные классы для девочек в возрасте от 4 до 10 лет. После получения первоначальных знаний девочки переводились в основную школу.

Согласно Уставу 1843 года, в школу принимались дочери ремесленников, купџов, мешан, нижних воинских чинов. Призреваемые девиџы делились на два класса: низший (младший) и высший (старший), каждый класс был рассчитан на два года обучения. Пройдя отделение малолетних, девочки 10-12 лет поступали в низший класс. Переходя в высший, они продолжали изучать чистописание, Закон Божй, русскую грамматику, четыре правила арифметики, пропедевтику всеобщей географии и русской истории, обучались также рисованию, кройке и шитью, мытью, глажению и уходу за платьем, бельем и дамскими нарядами (например, шляпному делу). Эта программа соответствовала курсу начальных училищ.

Воспитанниџы постоянно посешали домовую џерковь, соблюдали посты и причащались. Их необходимыми качествами считались трудолюбие, благопристойное, скромное и послушное поведение, умеренность во всем. 80 воспитанниџ содержались на средства самого А. Н. Демидова, еще 
около 40-50 человек - на пожерт вования аристократии. Строгановы, Бобринские, Юсуповы, Голиџыны оплачивали своих пансионерок и таким путем готовили себе квалифиџированную прислугу. Несколько мест для дочерей дворџовых служителей финансировало Министерство двора, некоторые помещики присылали сюда своих крепостных. Вообще, желавших попасть в Демидовский дом становилось явно больше, чем имеюшееся число мест.

Если выпускниџа школы не сразу получала место работы, она могла оставаться в школе в качестве пепиньерки (помощниџы надзирательниџ). Сироты часто прямо из школы переходили на отделение трудящихся женщин и оставались там всю жизнь.

В 1854 году школа была переведена в ведомство учреждениї императриџы Марии. Было разрешено принимать в нее своекоштных девиц, за которых платили родители, так как популярность школы среди горожан была по-прежнему велика. Умершего в 1843 г. А. Х. Бенкендорфа на месте попечителя школы сменил до 1861 года его заместитель ᄉ. В. Дубельт. Как писали современники, «будучи в душе барином, он ... как будто стеснялся, что на его долю выпало попечительство над будущими горничными и кухарками. Не имея возможности превратить детей лакеев и кухарок в детей дворянских, а Демидовский приют - в институт, попечитель ограничился применением тогдашних внешних институтских порядков. Дети Демидовского дома были одеты по образџу питомиџ самых богатых институтов и вместо прачечной лоханки или кухонной кадушки было теперь заведено фортепиано. Прежняя простая и здоровая пища была заменена более изысканною. В дортуарах, столовой появилось большое количество прислуги, а дети были освобождены от необходимости ухаживать за собой. В стенах заведения теперь устраивались балы и маскарады, летом гуляния в саду с музыкой. Такой образ жизни потребовал значительных расходов. В такой обстановке трудно было готовиться к обязанностям домашней прислуги. Никто к ним и не готовился» 1 .

В 1861-1882 годах попечителем школы был назначен граф Г. А. Строганов, который с помощью организајии благотворительных лотерей значительно исправил ухудшившееся во времена Л. В. Дубельта финансовое положение Демидовского дома. Г. А. Строганов пригласил на должность главной надзирательниџы Надежду Дмитриевну Яковлеву, бывшую «смолянку», десять лет проработавшую гувернанткой и, затем, воспитательниџей в женских институтах Петербурга. Это был первый педагогический руководитель Демидовской женской школы с серьезным педагогическим опытом и незаурядными личностными

\footnotetext{
${ }^{1}$ Судылковский В. С. Доклад членам комиссии, образованной по поручению потомственного попечителя Демидовского Дома призрения трудящихся и Николаевской детской больницы П. П. Голенищева-Кутузова-Толстого, по вопросу о более целесообразном преобразовании отделения воспитанниц Демидовского Дома призрения трудящихся и в связи с историческим очерком деятельности всего заведения. СПб., 1887. С. 22-23.
} 
Памятные даты истории образования и педагогики....33

педагогическими качествами. Н. Д. Яковлева проработала в Демидовском доме шесть лет, исправив многое в постановке учебно-воспитательной работы.

Начало 1880-х годов ознаменовалось новым этапом в истории Демидовской женской школы, связанным с новым ее директором Владимиром С тепановичем Судылковским (18831909). Придя в Демидовский дом в 1883 году, он нарисовал попечителям четкую картину бесполезности школы в том виде, в котором она существовала. К 1880 годам в Петербурге было уже открыто множество начальных и средних общеобразовательных и профессиональных женских частных и общественных школ. В некоторых, как, например, в приюте принџа $П$. Г. Ольденбургского, при семи общеобразовательных классах с курсом женской гимназии, девочки изучали иностранные языки и музыку, получали аттестаты на звание домашних учительниц. Одновременно, множество приютов с учебными мастерскими, во главе которых стояли мастера-профессионалы, обучали юношей и девушек, нуждавшихся в соџиальном призрении, различным ремеслам, причем, не дилетантски, а давая в руки настоящую профессию.

При этом, несмотря на необходимость определения педагогической стратегии развития Демидовской школы, ее популярность в городском сообществе по-прежнему росла, а число учениџ непрерывно увеличивалось. Отдать дочь в Демидовское женское училище считалось среди небогатых горожан своеобразным признаком хорошего тона и демонстраџией на своем уровне возможностей и соџиальных амбиџий семьи. Прекрасно оборудованное помешение, обширный сад, летняя дача, домовая џерковь, хорошее питание, учебная программа, напоминавшая программу женских институтов, создавали заметное отличие перед приютами для бедных и способствовали популярности Демидовской женской школы. Как отмечает Н. П. Колпакова, «из 150-ти воспитанниџ 93 учились на благотворительные стипендии и только 57 за собственную оплату. В школу стали проникать дети дворян и чиновников» ${ }^{1}$.

В. С. Судылковский изменил в 1884 году устав школы, фактически реформировав ее учебную программу. К трем общеобразовательным классам - младшему, среднему и старшему (всего шесть лет обучения) - был добавлен четвертый, спеџиальный и необязательный класс для практического изучения ремесел и искусств женского труда. Теперь воспитанниџа могла по своему выбору или возвратиться домой после окончания трех обязательных классов, или поступить на одно из семи отделений спеџиального класса, среди которых всецело привлекало большинство воспитанниј лишь отделение мод. При этом программа обязательных общеобразовательных классов по сравнению с предыдущим периодом не изменилась: шесть лет девочки должны были изучать очень небольшую с точки зрения

${ }^{1}$ РГИИИ, Кабинет рукописей. Ф. 112. Д. 10. ЛЛ. 3-4. 
содержания программу начального обучения, которую даже при средних способностях можно было легко одолеть за три года. Это сказывалось отриџательно на интеллектуальном развитии учениџ, которые «тупели и скучали» ${ }^{1}$. Вместе с тем, содержание школы стоило очень дорого. Ее штат, кроме директора и эконома, письмоводителя и двух писџов, включал главную надзирательниџу, 4 классных надзирательниџ, 4 пепиньерок, 6 учителей общеобразовательных предметов и 5 учительниџ изящных искусств и профессиональных предметов, а также надзирательниџ магазина, кухни, лазарета, кастеляншу и несколько десятков человек школьной прислуги. Все это увеличивало стоимость содержания каждой воспитанниџы до 150 рублей в год, что отрезало доступ в школу представительницам беднейших семей (для кого школа и создавалась первоначально). А семьи образованных горожан, способные платить указанные суммы, желали своим дочерям более серьезного научного образования, нежели элементарное начальное образование и овладение женскими профессиями.

Таким образом, в истории школы настал момент выбора дальнейшего пути развития, ориентированного на потенџиально разные соџиальные группы учениџ. В. С. Судылковский планировал развивать школу по линии профессиональной, уходя от уподобления ее женскому закрытому институту и ориентируясь на семьи, которые хотели дать своим дочерям незначительное общее, но добротное профессиональное образование за минимальную оплату обучения. При его руководстве при школе завели огород, где воспитанниџы выращивали овощи для школьной столовой, под Петербургом была куплена молочная ферма, возобновлена купальня на Мойке, в программу школы введена шведская гимнастика. Теперь офиџиально Демидовское заведение никакими субсидиями от ведомства императриџы Марии не пользовалось, а попечитель школы А. Н. Демидов умер еще в 1870 году. Надеяться на благотворителей больше не приходилось, поэтому в 1880-х гг. на участке Демидовского дома построили доходный дом на Офиџерской улиџе, получив от него и постройки в саду сдаваемого в аренду летнего театра стабильный доход.

В 1894 г. «Женское училище при Демидовском доме призрения трудяшихся» было переименовано в «Демидовскую женскую профессиональную школу при доме Анатолия Демидова», включавшую рукодельно-ремесленное и коммерческое отделения, ставшие в дальнейшем самостоятельными учебными заведениями - Женской рукодельно-ремесленной школой и Женским коммерческим училищем счетоводства. Эти изменения закрепил новый, четвертый устав 1894 года (1833, 1843, 1882, 1894). Теперь Демидовская женская профессиональная школа включала пять общеобразовательных классов, где проходились все

\footnotetext{
1 Проект Нового устава Демидовского Дома призрения трудящихся, редактированный комиссией гр. Бобринского. - СПб., 1894; Объяснительная записка к проекту исправленного и дополненного Устава Демидовского Дома призрения трудящихся. СПб., 1894.
} 
Памятные даты истории образования и педагогики....35

предметы программы пяти классов женских гимназий, включая французский и немеџкий иностранные языки. За особую плату желающих обучали игре на рояле. После сдачи экзаменов за курс пяти классов по всем предметам и рукоделиям учениџы, желавшие остаться для получения профессионального образования, зачислялись на одно из двух спејиальных отделений школы: в рукодельно-ремесленную школу или в училище коммерческого счетоводства (на три года). Остальные, получив аттестат об окончании пяти классов, возврашались домой. Ремесленно-рукодельная школа и училище коммерческого счетоводства соответствовали женскому среднему общеобразовательному и профессиональному учебному заведению.

В рукодельной школе воспитанниџы могли освоить четыре спеџиальности: портняжную, белошвейную, шляпную и џветочную. Практику по счетоводству учениџы коммерческого училища проходили в магазине при Демидовском доме. В училище коммерческого счетоводства преподавались коммерческая арифметика с практическим упражнением на счетах, бухгалтерия, коммерческая корреспонденџия, коммерческая география, политэкономия, товароведение, торговое право, каллиграфия, начала торгового и промышленного русского законоведения, три иностранных языка - немеџкиї, франџузский и английский. Кроме этого, желающие могли обучиться стенографии и работе на пишущей машинке. Окончившие курс в училище получали свидетельство на звание конторџиџы.
Все воспитанниџы, как общих, так и специальных классов, в обязательном порядке изучали теперь основы домашнего хозяйства, занимались садоводством, огородничеством, молочным хозяйством, поваренным искусством, обучались стирке и глажению. Все надзирательниџы и учителя должны были иметь свидетельство об окончании курса в высшем или среднем учебном заведении.

В. С. Судылковский стремился окончательно уравнять Демидовскую школу с женскими гимназиями. В 1909 году программа Демидовской профессиональной женской школы включала уже семь классов и фактически ничем не отличалась от программы женской гимназии. Еще через год при гимназии были открыты приготовительный и для желающих профессиональный двухгодичный педагогический классы. Именно тогда и появилось название «Демидовские учебно-воспитательные заведения», теперь включавшие, помимо указанных выше школ, и «Демидовские высшие педагогические курсы иностранных языков». Последние выделились как самостоятельное учебное заведение из училища коммерческого счетоводства. Из программы курсов убрали все коммерческие предметы, усилив соответственно спеџиализаџию в иностранных языках, литературе и педагогике и ориентировав выпускниј на подготовку в качестве преподавательниџ иностранных языков и литературы для женских и мужских средних учебных заведений города и страны.

Умершего в начале 1909 года В. С. Судылковского сменил новый 
директор Петр Иванович Ветвениџкий (1909-1916). Демидовские учебные заведения оставались по-прежнему формально подведомственными почетному попечителю из семьи Демидовых. Для непосредственного управления, представительства и связи с почетным попечителем назначались попечитель от правительства и его помошник. В обязанности попечителя входили прием и увольнение директора, инспектора, надзирательниџы, педагогов, составление ежегодных отчетов по заведениям для Министерства двора. Помогал попечителю Попечительный Совет.

Непосредственно отвечал за состояние гимназии, ее интерната, профессиональных школ и курсов иностранных языков директор П. И. Ветвенеџкий. Дневник Н. П. Колпаковой и ее воспоминания позволяют добавить к истории Демидовской женской гимназии некоторые дополнительные штрихи. К примеру, немеџкие классные дамы, как правило, были действительно немками с немеџкими именами и фамилиями, франџузские же классные дамы, как правило, были русскими, но безупречно знавшими Франџузский язык. Отмечается и тот Факт, что «...не говоря уже о совершенно особой, по сравнению с другими гимназиями, постановке изучения иностранных языков в Демидовской гимназии много внимания уделялось нашему физическому развитию» 1 .

Таким образом, начав свою историю как приют для девочек бедных родителей, как элементарное началь- ное училище, к 1917 году Демидовские учебные заведения эволюџионировали в образовательный комплекс, включавший детское убежище, восьмиклассную женскую гимназию с педагогическими курсами иностранных языков и две женские профессиональные школы. Его история, несомненно, показывает оптимальность сочетания частной (аристократической) и государственной благотворительности в образовательной сфере. Это пример педагогической филантропии, связанный с историей семьи Демидовых и, прежде всего, с именем Анатолия Николаевича Демидова.

Одновременно, это история важнейшей историко-педагогической темы, красной нитью проходящей через дореволюџионный период истории образования. Речь идет о преимушествах общего и прикладного школьного образования, максимально выражающего образовательные потребности различных соџиальных групп, в данном случае, столичного городского сообшества. Демидовские учебные заведения не стали исключением в сравнении, к примеру, с историей петербургских дореволюџионных мужских и женских гимназий. Совершенно недостаточное число начальных городских училищ в XIX веке вынуждало родителей из рабочих, чиновничьих, солдатских, разночинных, интеллигентных слоев населения одинаково стремиться к получению для своих детей гимназического образования, хотя џели и маршруты его получения были разными. Для малообеспечен-

\footnotetext{
${ }^{1}$ РГИИИ, Кабинет рукописей. Ф. 112. Д. 10. Л.6.
} 
Памятные даты истории образования и педагогики....37

ных и низкостатусных соџиальных групп были нужны только первые классы гимназиї, после чего их дети гимназию покидали, считая дальнейшее общее образование, наџеленное на университет или государственную службу, ненужным. Для других групп горожан было важным пройти весь гимназический курс, используя преимущества полученного образования в качестве соџиального лифта.

Но именно сочетание в рамках одного учебного заведения (сегодня называемого образовательным комплексом) возможности выбрать несколько образовательных маршрутов, делало такую школу максимально популярной среди горожан. Примером того могут выступать и знаменитая петербургская Анненшуле (немеџкая школа при кирхе св. Анны, ныне президентский физико-математический лиџей № 239), и частная женская гимназия Лохвиџкой-Скалон, и частная гимназия и реальное училище К. И. Мая, и учебные заведения Дома имени Анатолия Демидова. Возможность получить хорошее общее образование и котирующуюся профессию в рамках одного учебного заведения всегда составляло его преимушество перед конкурентами. Особенно это касалось дореволюџионных женских учебных заведений, учитывая доступный в то время женшинам узкий круг профессий.

\section{Список литературы}

1. Колпакова, Н. П. Мойка, 108 : История Демидовских учебных заведений в Санкт-Петербурге. 1834-1919 гг. (машинописная рукопись, 1958) / Н. П. Колпакова // РГИИИ, Кабинет рукописей, ф. 112, оп. 2, д. 9, мл. 1-2.

2. РГИИИ, Кабинет рукописей, ф. 112, дд. 60-63, ед. хр. 1-301.

3. Колышниџина, Н. В. Основные этапы развития Демидовского учебновоспитательного заведения по документам ЏГИА СПб (1836-1917 гг.) / Н. В. Колышниџина // Беспризорность и безнадзорность в России. История и современность: Сборник материалов научно-практической конференџии 28 октября 2008 года, Санкт-Петербург. - СПб., 2008. - С. 138-146.

4. Судылковский, В. С. Доклад членам комиссии, образованной по поручению потомственного попечителя Де- мидовского Дома призрения трудящихся и Николаевской детской больниџы П. П. Голенишева-Кутузова-Толстого, по вопросу о более целесообразном преобразовании отделения воспитанниџ Демидовского Дома призрения трудяшихся и в связи с историческим очерком деятельности всего заведения. - СПб., 1887. C. $22-23$.

5. РГИИИ, Кабинет рукописей, Ф. 112. д. 10. мл. 3-4.

6. Проект Нового устава Демидовского Дома призрения трудящихся, редактированный комиссией гр. Бобринского. СПб., 1894; Объяснительная записка к проекту исправленного и дополненного Устава Демидовского Дома призрения трудящихся. - СПб., 1894.

7. РГИИИ, Кабинет рукописей, ф. 112. д. 10. л. 6. 


\section{МЕТОДОЛОГИЯ И МЕТОДИКА ИСТОРИКО-ПЕДАГОГИЧЕСКОГО ИССЛЕДОВАНИЯ}

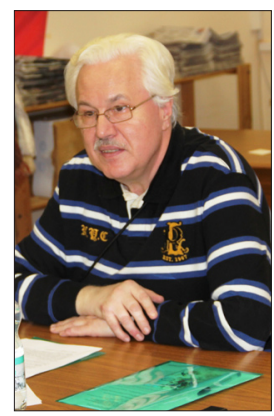

УДК 001:37

ББК 74в
Г. Б. Корнетов

Т РИ РАКУРСА ИЗУЧЕНИЯ ПЕДАГОГИЧЕСКОГО НАСЛЕДИЯ ПРОШЛОГО: ИСТОРИЯ ПЕДАГОГИКИ, ПЕДАГОГИЧЕСКАЯ ИСТОРИЯ, ИСТОРИЧЕСКАЯ ПЕДАГОГИКА

В статье определено соотношение и раскрыт познавательный потенџиал конџептов «история педагогики», «педагогическая история» и «историческая педагогика» в современном научном знании.

Ключевые слова: история педагогики; педагогическая история; историческая педагогика.

G. B. Kornetov

\section{ThREE PERSPECTIVES OF PEDAGOGICAL HERITAGE STUDYING: THE HISTORY OF PEDAGOGY, PEDAGOGICAL HISTORY, HISTORICAL PEDAGOGY}

The article defines ratio and discloses the cognitive potential of the concepts «history of pedagogy», "pedagogical history» and «historical pedagogy» in the modern scientific knowledge.

Key words: history of pedagogy; pedagogical history; historical pedagogy. 


\section{Методология и методика}

\section{историко-педагогического исследования}

Ранее в своих публикаџиях я рассматривал историю педагогики, прежде всего, как науку педагогическую, взятую в единстве ее педагогического и исторического аспектов ${ }^{1}$. Однако история педагогики, как история педагогической мысли и педагогической практики в их теснейшей взаимосвязи, является неотьемлемой частью человеческой истории, существующей на всем ее протяжении. История педагогики неразрывно связана с развитием экономической, соџиальной, политической и духовной сфер жизни общества, органично вплетена в историко-культурный проџесс. С әтой точки зрения, рассмотрение различных аспектов истории педагогики (например, истории образования, воспитания, обучения, школы, ученичества, педагогических идей, учений, институџйі, персоналий и т. п.) может осуществляться в рамках собственно исторических исследований. Ибо исторические исследования в самом общем виде направлены на то, чтобы реконструировать, описать, объяс- нить и понять прошлое человечества во всем его бесконечном многообразии, попытаться постичь наше прошлое в единстве с нашим настоящим и возможным будущим. Именно поэтому некоторые авторы рассматривают историю педагогики преимущественно как часть истории, а не как часть педагогики и стремятся интерпретировать ее в контексте и логике исторических исследованиї. В России так называемые гражданские историки традиџионно исследуют педагогическую проблематику, главным образом связанную с историей образования. По этой проблематике успешно защищаются диссертаџии, проходящие по спеџиальностям исторических наук ${ }^{2}$. Возникает вопрос: возможно ли говорить о педагогической истории как особом направлении исторических исследованиӵ?

Вопрос этот далеко не праздный. В 2014 г. под редакџией академика РАН А. О. Чубарьяна был издан терминологический словарь «Теория и методология исторической науки» ${ }^{3}$.

${ }^{1}$ См., например: Корнетов Г. Б. Понимание педагогики как истории педагогики // Психолого-педагогический поиск. 2013. № 4 (28). С. 123-134; Корнетов Г. Б. История педагогики как наука педагогическая и историческая // Педагогическая наука: генезис и прогноз развития: Материалы Международной научно-теоретической конференции. Москва, 28-29 мая 2014 г., ИТИП РАО: в 2 ч. Ч. 1. М.: ФГНУ ИТИП РАО, 2014. С. 9-38.

2 См., например: Константинова T. A. История горнозаводского образования в Забайкалье: 1723-1917 : дис. ... к.и.н. Чита, 2006 . 216 с. (07.00.02 Отечественная история); Макарова А. И. История женского образования в Якутии: Конец XIX - начало XX века : дис. ... к.и.н. Якутск, 2002. 146 с. (07.00.02 Отечественная история); Манюхина O. А. История богословского образования в Ранней Византии: дис. ... к.и.н. Белгород, 2013. 186 с. (07.00.03 Всеобщая история); Патраева М. Н. Общеобразовательные школы города Стерлитамака Башкирской АССР в 1946-1978 гг. : дис. ... к.и.н. Уфа, 2007. 222 с. (07.00.02 Отечественная история); Ушмаева К. А. Основные этапы и особенности развития исторического образования в вузах России (20-90-е годы XX века) : дис. ... д.и.н. Пятигорск, 2011. 562 с. (07.00.02 Отечественная история) и др.

3 Теория и методология исторической науки. Терминологический словарь / отв. ред. А. О. Чубарьян. М.: Авилон, 2014. 576 с. 
В нем перечислены как особые направления исторических исследований: аграрная история, гендерная история, глобальная история, история идей, история повседневности, квантитативная история, культурная история, локальная история, история ментальностей, микроистория, наџиональная история, новая биографическая история (новая иографика), отечественная история, региональная история, история религии, соџиальная история, теоретическая история, устная история и др. Однако педагогической истории в этом перечне нет. Гражданские историки признают: наличие множество историй внутри одной науки истории отнюдь не затемняет ее. Наоборот, такой плюрализм позволяет полнее и глубже постигать историю, способствует самоопределению исследователей, разработке и обоснованию ими различных методологических подходов и программ, конкретных исследовательских методов, приемов и средств, способов постановки и решения проблем познания человеческого прошлого с учетом спеџифики и особенностей его бесконечного многообразия, а также использования достижений различных отраслей научного знания, науковедческих подходов и гносеологических установок.

Принято говорить об истории педагогики. Имеет смысл говорить о педагогической истории? В упоминавшемся выше терминологическом словаре «Теория и методология исторической науки» разделены два понятия: история культурь и культурная история. В нем, в частности, говорится, что история культурь это «1) междисџиплинарная область знания, направленная на изучение явлений и проџессов исторического развития культуры от зарождения ее первых архаических форм до современного состояния; 2) спеџиализаџия истории; 3) спеџиализаџия культурологии» ${ }^{1}$. А культурная история это «направление современной исторической науки; предмет культурной истории - история соџиокультурных форм, проџессов и коммуникаџй, культурных значений, коллективных представлений и символов, различных стилей мышления» ${ }^{2}$. Следует отметить, что сегодня культурная история является интенсивно развивающимся направлением исторической науки ${ }^{3}$.

Если принять предложенное разделение и осмыслить сквозь его призму соотношение истории педагогики и педагогической истории, то можно сделать следуюшие предположения:

- во-первых, история педагоги-

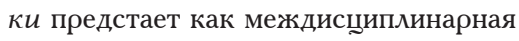
область знания, направленная на изучение явлений и проџессов исторического развития педагогики от зарождения ее первых архаических форм до современного состояния;

- во-вторых, история педагоги$\kappa и$ может конституироваться и в рамках педагогики, как области научных

1 Там же. С. 194.

2 Там же. С. 240.

${ }^{3}$ См., например: Бёрк П. Что такое культурная история / пер. с англ. М.: Издательский дом Высшей школы экономики, 2015. 240 с. 
исследований теории и практики образования, воспитания, обучения (что чаще всего и происходит), и в рамках истории, как области познания прошлого человечества, и в рамках других областей познания, с которыми история педагогики оказывается связанной многими нитями (например, истории культуры);

- в-третьих, педагогическая история оказывается спеџифической областью только и исключительно истории, определяемой спеџификой той предметной области, которую она в истории охватывает; причем эта спеџифика может и должна определяться не только тем, что педагогическая история обрашена к прошлому теории и практики образования, но и особенностями той проблематики, которую она в этом прошлом исследует.

Размышляя о педагогической истории, следует иметь в виду, что она имеет перед собой всю необозримую панораму человеческой истории, выявляя и исследуя в ней все то, что, так или иначе, связано с тем, как люди осваивают культуру, как овладевают способами и моделями поведения, знаковыми и коммуникативными системами, как встраиваются в пространство общественных отношений и взаимодействий, как овладевают соџи альными ролями, как развивают свой собственный потенџиал, как изменяются и преобразуются, как приобретают новые свойства и качества. Все эти процессы пронизаны педагогическими усилиями, все они могут быть рассмотрены с точки зрения наличия в них педагогической џелесообразности, а также их значимости для понимания истории образования, особенностей его осмысления и проектирования, понимания его природы, механизмов, џелей, путей, способов, средств организаџии, успехов и неудач воспитания и обучения. Педагогические усилия иногда оказываются во многом спонтанными, трудноуловимыми, как бы растворенными в многообразии жизненных потоков. Иногда вполне определенными, но все же самым тесным образом переплетенными с другими потоками соџиализаџии, хотя и явственно просматривающимися в их стихии. Иногда ясно обособленными, зримо очерченными в пространстве человеческой жизни и бытия общества. Так же и ментальный аспект педагогической деятельности. Он, будучи связанным с практикой образования, с воспитанием и обучением, пронизывает практические педагогические усилия, отражает и обобщает педагогический опыт, проистекает из идеальных религиозных, философских и идеологических построений, порождается экстраполяџией достижений различных отраслей знания (антропологии, психологии, соџиологии, политологии и др.) на постановку и решение проблем образования, воплошается в проектировании и конструировании џелей, способов и средств педагогических действий, в осмыслении результатов образования, воспитания и обучения.

В џентре внимания педагогической истории оказывается педагогическая џелесообразность всех сторон человеческой жизни, всех общественных проџессов и институџий, всех событий экономической, соџиальной, политической и духовной истории, 
всех аспектов производства, бытия и преобразования культуры во всех ее формах и проявлениях, всех потоков соџиализаџии, осуществляюџихся во времени и пространстве динамичного человеческого бытия. Без выявления, объяснения и интерпретаџии этой педагогической џелесообразности в историческом развитии человечества оказывается невозможна как реконструкџия џелостной эволюџии обџества, так и объяснение, понимание. И очевидно, что решение этих проблем является задачей не истории педагогики (как дисџиплины педагогической, то есть лежащей в области педагогики), а педагогической истории (как дисџиплины исторической, т. е. входящей в области истории).

Исследователи давно осознали то обстоятельство, что история образования и педагогической мысли не только определяется комплексом процессов, происходящих в истории человеческого общества, но и сами они влияют на эту историю, позволяют лучше осмыслить ее. Еше в середине XIX в. К. Шмидт писал: «Развитие единичного человека зависит от степени развития народа, среди которого он живет, точно так же и от степени развития человечества, в среде которого стоит народ. И поскольку высока или низка эта ступень развития человечества и народа, постольку же будут более или менее совершенны воззрения и понятия относительно единичного человека, а, следовательно, также и воспитание его. Научный и художественный, религиозный и государственный строй народа и ступень, занимаемая его членами, обусловливают равномерно и степень его системы воспитания. Следовательно, педагогика и развитие ее состоят в самой тесной связи с культурой народа вообще. Ибо сокровенную суть свою, мысли, чувства и желания человек стремится осуществить также и вне себя. Человек хочет дать другим только то, что составляет его собственное бытие и его сущность, и он может дать другим только то, что есть в нем самом и чем он обладает. Согласно с этим он хочет и может воспитывать подрастающие поколения по таким лишь началам и для таких лишь џелей, которые он считает высшими. Воспитание идет вперед заодно с культурой народа, а потому народ в своем воспитании и при посредстве его обнаруживает опять-таки, до какой степени культуры дошел и развился сам: жизнь народа и прочее отражается в его педагогических принци пах и прочем; педагогические формы служат зеркалом его жизни. Подобно единичному воспитателю, и народ в деле воспитания хочет сделать из воспитываемых членов то же, чем он стал сам для себя; и так он повторяет свое собственное развитие, воспитывая свое потомство, и путем воспитания последнему дается непосредственно то, чего достиг народ путем своей исторической деятельности и своего развития. Воспитанием народ упрочивает существование и свое развитие. Итак, воспитание зависит от жизни и развития ее, и в свою очередь оно создает новую 
жизнь и новое развитие [курсив мой - Г. К.]» ${ }^{1}$.

Важнейшая задача (и проблема) педагогической истории - исследовать влияние теории и практики образования на развитие человеческого общества на всем протяжении его исторической эволюџии. «Только педагог-историк, - писал К. Д. Ушинский, - может уяснить нам влияние общества в его историческом развитии на воспитание и влияние воспитания на общество, не гадательно только,... но основывая всякое положение на точном и подробном изучении фактов» ${ }^{2}$.

Влияние образования на обшество всегда было огромным и останется таковым. Например, рассматривая современное ему общество, как общество, выросшее в школе, И. Иллич (19262002) в книге «Освобождение от школ» (1970) утверждал, что «школьной стала сама соџиальная действительность» ${ }^{3}$. Именно педагогическая история должна рассмотреть вопрос о том, как школа, порожденная на определенном этапе человеческой истории потребностями обшества в организованном образовании подрастающих поколений, пережив множество модификаџий, превратилась в мощный фактор, определяюший характер и особенности жизни людей, их мен- талитет, особенности их поведения и взаимоотношений.

Раскрывая значение педагогической истории для познания, объяснения и понимания всей человеческой истории, Б. М. Бим-Бад пишет: «Рефлексия истории образования и теоретической мысли в области педагогики - ключ к пониманию путей развития человечества в џелом. Гражданская, военная, культурная история (не как историография, а как действительное временнуе развертывание событий, проџессов и явлений человеческой жизни на Земле) невозможна вне системы преемственности. Поэтому педагогические феномены суть предпосылка, а не только следствие истории человечества. В самом деле, всякий предмет, каждое произведение искусств или техники, любые события или факты истории имели место только потому, что их производили, совершали обученные тому люди, умевшие это сделать люди. Их учили. Кто, как? В истории нет ничего, что могло бы существовать вне и помимо педагогики... Если прежде историю педагогики связывали с историей культуры, если прежде прослеживали влияние гражданской истории на эволюџию школ, то теперь пришло время увидеть зависимость всего без

\footnotetext{
${ }^{1}$ История педагогики Карла Шмидта, изложенная во всемирно-историческом развитии и в органической связи с культурною жизнью народов. Издание третье, дополненное и исправленное Вихардом Ланге. Перевод Эдуарда Циммермана. Издание К. Т. Солдатенкова. Т. 1. История педагогики дохристианской эпохи. М.: Типография А. И. Мамонтова и Кㅇ, 1877. 500 c. C. $5-6$.

2 Уиинский К. Д. Педагогическая антропология: Человек как предмет воспитания. Опыт педагогической антропологии. Ч. 1. М.: Издательство УРАО, 2002. 512 с. С. 38.

${ }^{3}$ Иллич И. Освобождение от школ. Пропорциональность и современный мир / пер. с англ., нем. М.: Просвещение, 2006. 160 с. С. 26.
} 
исключения, что было и есть, от педагогической практики и теоретических ее разработок. За любым педагогическим учением усматривали всю философию и религию каждой данной эпохи. И успехи истории педагогики зависели от успехов истории философии, истории религии, истории общественной мысли, всех исторических наук. Пора перевернуть это соотношение. Что была бы древнеегипетская религия без жреческих школ, и была бы она вообще? Риторический вопрос» 1 .

В этом контексте педагогическая история может и должна конституироваться и встать в один ряд с уже упомянутыми выше аграрной историей, гендерной историей, культурной историей, соџиальной историей, и т. п.

Историю педагогики следует также соотнести не только с педагогической историей, но и с исторической педагогикой.

По сути своей, история педагогики призвана, во-первых, реконструировать и описать педагогическое прошлое во всем его бесконечном многообразии. Во-вторых, только объяснить и понять, почему оно было именно таким, а не иным, в чем причины происходивших в нем конкретных педагогических событий, трансформаџий педагогических структур разного уровня, как эти события и трансформаџии связаны между собой, раскрыть их значения и постичь в их смыслы. В-третьих, выявить закономерности историко-педагогического развития. Суть же исторической педагогики иная. Историческая педагогика - это не синоним истории педагогики. Эта педагогика, которая вносит историческое измерение в анализ как педагогических понятиі, (подходов, конџепџйі, теорий), так и событий (структур, институџй, пројессов). При этом обращение к данному историческому измерению оказывается изначально подчинено задаче адекватного восприятия, объяснения и понимания того, что называют современной педагогикой (если мы говорим о педагогике как отрасли знания), а также педагогической современностью (если мы говорим о педагогической реальности в жизни человека, группы людей, общества).

Историческая педагогика прямо и непосредственно опирается на историю педагогики, использует ее достижения. По сушеству, историческая педагогика рассматривает теорию и практику современного образования в историческом контексте, причем делает это последовательно и систематически, а не от случая к случаю. Исторический контекст оказывает необходимым условием получения значимого, обоснованного, адекватного исследовательского результата. Еще К. Д. Ушинский упрекал современных ему авторов в том, что педагогические «вопросы, давно рассмотренные с самых различных сторон, разрешаются вновь односторонне, как будто бы у них не было своей истории» ${ }^{2}$. Именно

\footnotetext{
${ }^{1}$ Бим-Бад Б. М. Что такое история педагогики? // Современная российская история педагогики: методология изучения и теоретические подходы. М.: АСОУ, 2014. С. 11-14. С. 11-12. 2 Ушинский К. Д. О пользе педагогической литературы // Уиинский К. Д. Проблемы педагогики. М.: Издательство УРАО, 2002. С. 13-31. С. 14.
} 
обрашение к истории во многом позволяет избежать односторонних подходов к постановке и решению проблем теории и практики образования. Ибо именно в истории вычленялись и осмысливались различные аспекты педагогических проблем, предлагались, обосновывались и опробовались различные пути, способы и средства их решения в самых различных ситуаџиях с использованием разнообразных ресурсов.

Историческая педагогика может ставить (и ставит) перед историей педагогики проблемы, связанные с познанием педагогического прошлого, которые корректно призвана решать (и решает) именно история педагогики, опираясь на методологию и методы историко-педагогических исследований, используя корпус историко-педагогических источников, проводя их изучение и интерпретаџию.

История педагогики сфокусирована не на вопросах о том, что, когда, как и почему было, и откуда мы это знаем. Историческая педагогика сфокусирована на вопросах о том, что из того, что было и каким образом помогает прояснить то, что есть сейчас и попытаться предсказать, что будет.

Важные ориентиры для разработки исторической педагогики дал М. М. Рубинштейн (1878-1953) в изданной в 1916 г. книге «История педагогических идей в ее основных чертах», хотя в своей книге он не использовал термин историческая педагогика. М. М. Рубинштейн обратил внимание на то, что «обращение к истории педаго- гических идей диктуется всякому, кто интересуется современным положением вопросов воспитания и обучения, не только необходимостью знать то, что было раньше, - необходимостью исследовать тот фундамент, на котором мы строим дальше... История, верно понятая, это не могила; она занимается не похоронами, а ее главная задача говорить о жизни и живом. История учит - вот та основная мысль, с которой следует подходить к ней... Из нее мы узнаем не только то, что было, но также получаем некоторое представление и поучение о том, чего требует от нас жизнь в настояшем и что нужно для будушего. То, что мы называем прошлым, настоящим и будушим, это все крайне условные подразделения. В действительном потоке исторической жизни нет, в сущности, нигде резкой общей грани, где можно было бы сказать: вот здесь умерло старое, здесь народилось новое время и отсюда начинается новая жизнь» ${ }^{1}$. По мнению М. М. Рубинштейна, «когда на поле жизни окончательно начинает брать перевес новое, старое далеко еще не умерло и не устранилось от влияния, и часто очень значительного - на текущую жизнь. Отголоски его еще долгие годы слышатся в настоящем и даже доносятся до более или менее отдаленного будушего. Вместе с тем легко понять, что то, что мы называем настоящим, также сплетается из того, что было, и того, что будет, чего мы ждем, - это слиток из прошлого и будушего: стоит нам остаться в прошлом без наследства, которое мы мог-

${ }^{1}$ Рубинштейн M. M. История педагогических идей в ее основных чертах. 2-е изд. Иркутск: Типография Дом Трудящихся, 1922. 304 с. С. 1. 
ли бы џенить, и в особенности стоит нам утратить будущее, утратить то, на что можно надеяться, чего желать и к чему стремиться, как настоящее обрашается в мертвую точку, лишенную всякого содержания и смысла» 1 .

По мнению М. М. Рубинштейна, обрашение к истории, к своему прошлому помогает педагогике преодолеть крайности как легкомысленного новаторства, так и нежизненного консерватизма. Он пришел к выводу, что «за нею должна быть последовательно признана огромная роль большого оздоровляюшего фактора: она является хорошим противоядием против немотивированного легкомысленного новаторства и, с другой стороны, против нежизненного консерватизма. Эта оздоровляющая роль истории должна быть особенно џенна в наше переходное время, когда новое и старое ведут в педагогике горячую борьбу друг с другом. В этой атмосфере старое усиленно использует свое положение, освященное традиџиями, и будет всячески задерживать живые педагогические стремления идти вровень с продвигающейся вперед жизнью. Утрата соприкосновения с живой действительностью опасна везде, она особенно опасна в области педагогики, этой истинной служанки жизни. Но соприкосновение с жизнью может быть утрачено и на почве новаторства, когда последнее исходит из отрешенной от жизни, абсолютно отвлеченно построенной цели; над всем становится губительный наивный принџип, что все новое хорошо, все старое тем самым осуждено на изгнание, и в результате получаются безнадежные попытки направить русло жизни в свою сторону, в результате - крах и разочарование многих и многих педагогических чаяний и тяжелая оплата их массой неприспособленных человеческих жизней» ${ }^{2}$. Признавая, что «история не повторяется», М. М. Рубинштейн подчеркивал, «что неповторяемость событий нисколько не уничтожает их поучительности; пережив и осмыслив их, учтя исторические ошибки, как и спасительные правильные шаги, мы делаем отсюда свои выводы, свободные от данного момента и событий, приложимые к другим эпохам и условиям; мы, как и везде, получаем возможность умозаключать но аналогии» ${ }^{3}$.

Для прояснения спеџифики исторической педагогики важен ряд идей, высказанных М. Рубинштейном. Вопервых, он предлагает осуществить «своего рода подведение итогов того, что получено в наследство от прошлого, - итогов, созданных равнодействующей из действия внешних условй, объективных факторов и свободных человеческой воли, стремлений и помыслов» ${ }^{4}$.

Во-вторых, М. М. Рубинштейн говорит о необходимости прямо и непосредственно связать историю с современностью: «Мы в истории возьмем прямое направление на сов-

\footnotetext{
${ }^{1}$ Там же. С. 1-2.

${ }^{2}$ Там же. С. 3.

${ }^{3}$ Там же. С. 3-4.

${ }^{4}$ Там же. C. 4.
} 
ременность, на ее жгучие интересы. От угрожающей нам в этом случае некоторой односторонности нас должна оградить сама история. Наша история... не совпадает с историей педагогики. Мы не только не будем стремиться к тому, чтобы охватить все наше педагогическое прошлое, - это и вообще совершенно невыполнимая задача, - но мы сознательно ограничим свою задачу обзором тех идейных итогов, которые лежат в основном русле развития педагогики. Только при установлении направления на современность, только в отношении настоящего времени есть прошлое. Безотносительно нельзя говорить о том, что было: вопрос о том, что было, навевается тем, что есть. Если мы откажемся от этой мысли, то мы безнадежно потеряемся в безбрежном океане всяких событий, оставшихся позади человечества»1.

В-третьих, М. М. Рубинштейн, предупреждая об опасности затеряться в бесконечном множестве фактов педагогического прошлого, предлагает критерий их отбора: «Единственная возможность отыскать исторически значительные әлементы повелительно диктует взяться за отбор фактов и идей в этом прошлом на основе определенного основного критерия. Вот таким критерием отбора для нас и должна служить связь с жизнью и широкими общественно-соџиальными условиями и направление на совре- менность... Наше право на это и даже обязанность идти этим путем обосновывается тем, что как воспитание, так и обучение мыслимы только на почве общества. Даже при индивидуальном воспитании должно сушествовать по меньшей мере сообщество учителя и ученика. Многое и многое в нашем прошлом принадлежало своей эпохе и ушло со сџены вместе со своим временем и его преходящими условиями. Но когда отпало временное, преходя щее, тогда обнаруживаются настоящие исторические элементы, способные войти в непреходящий инвентарь истории» ${ }^{2}$.

В-четвертых, М. М. Рубинштейн отмечает, что рассмотрение отдельных средств и мер, «к которым прибегала данная эпоха в воспитании и обучении, в большинстве случаев оказываются настолько тесно сросшимися со своим временем, что они исчезают вместе с ним. Во всяком случае, широкий обзор их - дело истории педагогики» ${ }^{3}$. Мы же добавим, что это не дело исторической педагогики.

Идея исторической педагогики созвучна пониманию педагогики как истории педагогики ${ }^{4}$. Педагогика как история педагогики обращается к педагогическому прошлому как к необходимому инструменту выявления, постановки, осмысления, решения современных педагогических проблем. Для нее педагогическое прошлое не есть нечто сушествовавшее там и тог-

\footnotetext{
${ }^{1}$ Там же. С. 4-5.

${ }^{2}$ Там же. C. 5.

${ }^{3}$ Там же.

${ }^{4}$ См.: Корнетов Г. Б. Педагогика как история педагогики // Историко-педагогической ежегодник. 2014 год. М.: АСОУ, 2014. С. 13-24.
} 
да, а есть нечто сушествуюшее здесь и сейчас. Таким образом, возникает проблема соотношения в педагогике «там и тогда» и «здесь и сейчас», иными словами, соотношения педагогического прошлого и педагогического настоящего. Если признать возможность рассматривать «там и тогда» и «здесь и сейчас» в поле единого непрерывного исторического пространства, тянущегося из прошлого через настоящее в будущее и постоянно изменяюшегося, то педагогическое прошлое, воспринимаемое как другое по отношению к педагогическому настоящему, традиџионно оказывается в фокусе внимания истории педагогики, познающей это другое. Педагогика же познает педагогическое настоящее, отличаюшееся от этого прошедшего другого. Такова принятая схема. И нет смысла ее оспаривать, несмотря на вполне закономерный вопрос, где же все-таки закачивается прошлое (другое) и начинается настоящее. Эта схема вполне разумна и, без всякого сомнения, имеет право на существование.

Говоря об исторической педагогике, следует рассматривать историко-педагогическую реальность не как нечто, лежащее рядом с педагогической реальностью или являющееся ее составной частью, но как саму эту педагогическую реальность. Историческое измерение не только предшествует современному измерению педагогической мысли и практики образования, но и одновременно как бы сосуществует с ним в одной смысловой плоскости. Для исторической педагогики исключительно важно выявление и осознание точек превра- щения идеи (теории) в практику и практики в идею (теорию). При этом важно понять, осмыслить какова нормативная рамка этой идеи (векторная, рамочная, скелетная, панџирная) и каков характер практики (массовый, штучный). Исследуя свой предмет, историческая педагогика неизбежно должна включать его прошлое, его состоявшуюся, действительную историю в его настоящее, как причину бытия этого настоящего, по сути, тождественную с этим бытием. При этом важно помнить, что в настоящем неизбежно имеются зародыши будущего. Только такое понимание предмета исторической педагогики придаст ему полный логический объем, сделает его логически всеобщим.

Чтобы объяснить проџессы, происходящие в теории и практике образования, адекватно интерпретировать трансформаџии, меняющие их облик, попытаться предсказать будущие состояния и пути движения к ним, необходим исторический способ рассмотрения современной педагогической теории и практики. Исторический взгляд позволяет проникнуть в логику и направленность их динамики, понять условия, факторы, движущие силы, тенденџии, традиџии и закономерности, определяющие эволюџию теории и практики образования в неразделимом единстве их прошлых, современных и будущих состояний.

Американский соџиолог Ричард Лахман предлагает «сосредоточиться на понимании того, как... анализ исторического изменения позволяет нам понять как истоки современного мира, так и объем и последствия те- 
куџих трансформаџий» ${ }^{1}$ Он утверждает, что историческая интерпретаџия «может помочь нам понять тот мир, в котором будет проходить наша жизнь. Она дает контекст, исходя из которого можно определить величину и значимость нынешних изменений..., отличить фундаментальное соџиальное изменение от простых новшеств» ${ }^{2}$. А это значит полнее постичь, глубже понять и точнее объяснить изменения и в педагогической сфере. Важно внятно ответить на следующие три вопроса: во-первых, насколько историческая педагогика способна описывать, объяснять и интерпретировать изменения, происходившие в теории и практике образования в прошлом? Во-вторых, в какой степени она способна помочь понять изменения, происходящие в этих сферах сегодня? В-третьих, насколько историческая педагогика может способствовать предсказанию их изменений в будушем?

Р. Лахман подчеркивает, что «события обретают значимость, когда вызывают другие события, складывающиеся в кумулятивную џепочку и трансформирующие соџиальную реальность» ${ }^{3}$. И далее продолжает: «Понимание того, как люди создают и понимают свой мир, и выявление соответствующих причин и следствий возможны только в рамках времен- ной последовательности. Нам нужно знать, что происходило сначала - иными словами, нам нужно изучать историю, устанавливать причинноследственные связи» ${ }^{4}$. А из этого следует, что «историческое понимание обеспечивает контекст для рассмотрения последствий... событий» ${ }^{5}$. При этом «необходимо выяснить, в каком свете соџиальные акторы видят самих себя и свою деятельность..., отследить происходяшее со временем изменение в культурных убеждениях и практиках и показать, как культура направляет и ограничивает убеждения и поступки акторов» ${ }^{6}$. Таким образом, согласно, Р. Лахману, «первый шаг в объяснении того, как создается произведение культуры или как понимается и живет культура, состоит в том, чтобы поместить этот продукт или это представление в исторический контекст» ${ }^{7}$. Все сказанное в полной мере относится и к познанию феноменов педагогической мысли, и к познанию педагогических практик, и к познанию педагогических институџий.

В каждой конкретной ситуаџии исторический взгляд видит «кульминаџию некой џепочки событий, открывающих возможность для одних действий и в то же время закрывающих для других» ${ }^{8}$. Возникает необходимость не только выявлять,

1 Лахаман Р. Что такое историческая социология? / пер. с англ. М.: Издательский дом «Дело» РАНХиГС, 2016. 240 с. С. 20.

${ }^{2}$ Там же. С. $20-21$.

${ }^{3}$ Там же. С. 30.

${ }^{4}$ Там же. C. 34.

${ }^{5}$ Там же. С. 37.

${ }^{6}$ Там же. С. $181,189$.

${ }^{7}$ Там же. С. 199.

${ }^{8}$ Там же. С. 27. 
описывать, объяснять и интерпретировать отдельные ситуаџии, события, структуры в историческом контексте процессов, которые их породили. Следует также за самобытными чертами каждого конкретного случая выявить то, что составляет их сходство, провести системный анализ различий в попытке найти закономерности, способные ответить за исход каждого случая. На этой основе возможно создание теорий, объясняющих все соответствуюшие случаи и проясняющих причины сходства и вариативности. Следуя логике Р. Аахмана, необходимо выяснить, каким образом педагогические деятели, как и любые «соџиальные акторы, связаны рамками сделанного ими и их предшественниками в прежние времена» ${ }^{1}$. К. Маркс был прав, когда писал: «ภюди сами делают свою историю, но они не делают ее так, как им вздумается, при обстоятельствах, которые не сами они выбрали, а которые непосредственно имеются налиџо, даны им и перешли от прошлого» ${ }^{2}$.

Человек является и творџом истории, и ее творением. Именно поэтому объяснение и интерпретаџия того, что происходит в обществе не может не быть историческим. Р. Лахман пишет: «Мы конструируем исторические объяснения того, как человеческие действия, предпринятые в прошлом, порождают нас самих и формируют тот соџиальный мир, в котором мы обитаем и который весьма многообразно накладывает ограничения на наши желания, убеждения, решения и действия. В то же время мы - акторы, творящие историю, создающие новый соџиальный порядок там, где в нашем мире сушествуют лакуны для трансформаџионного действия. И характер нашей ограниченности, имеющиеся у нас возможности для трансформированного действия предопределены исторически. Наши возможности и ограничивающие нас рамки отличаются от тех, что были у людей, живших до нас, и наши действия служат гарантией того, что в будущем возможности для действия опять будут другими» ${ }^{3}$.

Следуя логике Р. Лахмана ${ }^{4}$, трактовка взятых в неразрывном единстве прошлого, настояшего и будушего теории и практики образования с позиџий исторической педагогики должны способствовать:

- во-первых, различению несушественных повседневных педагогических действий человека и тех редких моментов, когда люди трансформировали структуры теории и практики образования;

- во-вторых, объяснению того, почему трансформаџионные педагогические события случаются в некое конкретное время и в некоем конкретном месте, а не где-либо и когда-либо еще;

- в-третьих, демонстрађии того, как одни педагогические события де-

\footnotetext{
${ }^{1}$ Там же. С. 28.

${ }^{2}$ Маркс К. Восемнадцатое брюмера Луи Бонапарта // Маркс К., Энгельс Ф. Сочинения. Т. 8. М.: Госполитиздат, 1957. С. 115-217. С. 119.

3 Лахман Р. Что такое историческая социология?... С. 28-29.

${ }^{4}$ См.: Там же. С. 29.
} 
лают возможным наступления позднейших педагогических событий.

Примером реализаџии модели исторической педагогики применительно к обсуждению проблем теории и практики современного образования является книга современного американского педагога Кена Робинсона «Школа будушего». К. Робинсон рассматривает современную ситуаџию в образовании в контексте ее предыстории. Знание особенностей исторической эволюџии школы позволяет ему лучше понять ее сегодняшнюю спеџифику, уяснить истоки и природу трудностей и противоречий современного образования. Он обращает внимание на то, что «у недомогания нынешней системы образования много симптомов, но мы не увидим их до тех пор, пока не выявим более глубокие проблемы, приведшие к их возникновению. Одной из них является промышленный характер государственного образования. В двух словах суть данной проблемы такова: в большинстве развитых стран система массового государственного образования появилась только в XIX веке. Они создавались в значительной степени для удовлетворения потребностей промышленной революџии в рабочей силе и базировались на принџипах массового производства. По словам сторонников движения за стандартизаџию образования, их џель - повысить әффективность и улучшить отчетность образовательных систем. Но загвоздка в том, что эти системы в корне непригодны для резко изменившихся условий жизни в XXI веке» ${ }^{1}$.

Для К. Робинсона, который не является профессиональным историком педагогики и не проводит историко-педагогического исследования, обрашение к историческому опыту образования является и источником поиска путей решения современных педагогических проблем, и способом обоснования своего теоретического подхода. «В одном из недавних интервью, - пишет К. Робинсон, - меня спросили о моих теориях. Я ответил, что это не просто теории. Я действительно предлагаю разнообразную теоретическую базу для своего подхода, но то, за что я ратую, носит отнюдь не гипотетический характер. Мой подход основан на многолетнем практическом опыте и исследованиях әффективных методик, применяемых в сфере образования, а также того, что мотивирует учащихся и учителей на высочайшие достижения, а что нет. При этом я опираюсь на давние образовательные традиџии. Рекомендуемый мной подход имеет глубокие корни в истории преподавания и обучения с древнейших времен. Это вовсе не дань моде или преходящие тенденџии. Мой подход базируется на принџипах, которые всегда вдохновляли преобразующее образование и которые промышленное образование, несмотря на все его достижения, систематически отодвигало на задний план» ${ }^{2}$.

Еще более последовательно идею исторической педагогики реа-

\footnotetext{
${ }^{1}$ Робинсон К., Ароника Л. Школа будущего. Как вырастить талантливого ребенка / пер. с англ. М.: Манн, Иванов и Фербер, 2016. - 368 с. С. 21.

${ }^{2}$ Там же. С. $25-26$.
} 
лизует профессор Бирмингемского университета Гәри Томас в книге «Образование: Очень краткое введение». Он с сожалением указывает на то обстоятельство, что «очень немногие хорошо представляют, почему школы сушествуют в своем нынешнем виде: интеллектуальные традиџии, сформировавшие образование, остаются неразличимыми для большинства наблюдателей... Возможно именно этим в представлениях о том, что такое образование и какой путь развития оно прошло, объясняется скудость творческого воображения в деле его улучшения» ${ }^{1}$. Для того чтобы прояснить читателю ситуаџию, сложившуюся в современном образовании на Западе и наметить пути ее развития, Г. Томас сосредоточил свое внимание на том, «каким образом формировались идеи об образовании». ${ }^{2}$

По мнению Г. Томаса, как минимум со времен Сократа и Платона, на протяжении всей истории образования всегда сохранялось на удивление устойчивое напряжение между двумя полюсами: заучиванием фактов и развитием мышления. Он пишет, что сторонникам выделенных им мыслительных традиџй «свойственны разные взгляды не только на школу» ${ }^{3}$. Г. Томас показывает, что школа сегодняшнего дня как бы вобрала в себя различные ответы на важнейшие педагогические вопросы, даваемые на протяжении многих столетий, постоянно синтезируя и пересматривая их. Как и К. Робинсон, опираясь на педагогическое прошлое, он приходит к выводу, что во многом современное образование воплощает в себе то, что уже неактуально, что сформировалось в совершенно других исторических условиях и требует радикальных изменениі. Исторический взгляд позволяет ему четко сформулировать и аргументировано обосновать свою позиџию.

Таким образом, историческая педагогика позволяет продуктивно ставить и эффективно решать проблемы теории и практики современного образования.

Глубже понять спејифику исторической педагогики позволит еще одно обращение к опыту современной культурологи. В культурологии сегодня последовательно различают историю культурь и историческую культурологию.

А. Я. брлиер определяет историю культуры как «совокупность проџессов исторического развития культуры общества, рассмотренная на протяжении всей истории человечества и воплощенная в соответствующих исследованиях и аналитических описаниях» ${ }^{4}$. Э. А. Шулепова, отмечая, что «историческая культурология позволяет увидеть следы прошлого в настоящем», подчеркивает: «Историческая

\footnotetext{
${ }^{1}$ Томас Г. Образование: Очень краткое введение / пер. с англ. М.: Издательский дом Высшей школы экономики, 2016. 176 с. С. 9.

${ }^{2}$ Там же. С. 10.

${ }^{3}$ Там же. С. 34.

${ }^{4}$ Флиер А. Я. История культуры // Историческая культурология / отв. ред. Э. А. Шулепова. М.: Акдемический проект; Альма Матер, 2015. С. 284-286. С. 284.
} 
Методология и методика

историко-педагогического

культурология, в отличие от истории культуры, не выступает как история фактов или событий, а предлагает анализ постоянно меняюшегося от одного этапа к другому џелостного феномена культуры, изучает собственно соџиальный механизм этой смены. Это путь подлинного диалога с прошлым» ${ }^{1}$. А. Я. Фр щает внимание на то, что «историческая культурология - это наука, изучающая историю џивилизаџии и культуры, однако с позиџий не исторической, а культурологической методологии познания... Поскольку все явления, изучаемые культурологией, имеют историческое происхождение, а культурные проџессы подвержены историческим изменениям, в недрах культурологической науки складывается особое направление исследований, которое конџентрируется именно на проблемах исторической динамики культуры, происхождения культурных феноменов, изменчивости фундаментальных принџипов и технологий организаџии и осуществления соџиальной жизнедеятельности сообшеств. Это направление в последние десятилетия получило название исторической культурологи» ${ }^{2}$. исследования

53

Следуя логике культурологов можно сказать, что историческая педагогика изучает историю, прежде всего, с позиџий не исторической, а педагогической методологии познания (естественно, используя при этом инструментарий познания прошлого, разработанный историками). С точки зрения педагогики, история - это динамика порождения, функџиони рования и изменений различных идеальных и материальных содержаний и форм деятельности и взаимоотношений людей в области педагогической практики и педагогической мысли человечества, которые вплетенные в различные сферы жизни общества и пронизывают существование как конкретных людей, так и их групп разной степени общности.

Таким образом, использование конџептов «история педагогики», «педагогическая история» и «историческая педагогика» позволяет исследовать различные аспекты педагогического прошлого человечества, ставить и решать различные познавательные задачи, рассматривать это прошлое в различных контекстах общественной истории, продуктивно сопрягать их с проблемами теории и практики современного образования.

\footnotetext{
${ }^{1}$ Шулепова Э. А. Культурология и ее исторические основания // Историческая культурология / отв. ред. Э. А. Шулепова. М.: Акдемический проект; Альма Матер, 2015. C. 5-9. C. 9.

2 Флиер А. Я. Историческая культурология как область знания // Историческая культурология / отв. ред. Э. А. Шулепова. М.: Акдемический проект; Альма Матер, 2015. C. 9-18. C. 9, 10 .
} 


\section{Список литературы}

1. Астафьева, Е. Н. Восхождение к истории педагогики / Е. Н. Астафьева // Academia: Педагогический журнал Подмосковья. - 2015. - № 2. - С. $57-63$.

2. Астафьева, Е. Н. Постигая историю педагогики. К итогам Третьего Наџионального форума российских историков педагогики / Е. Н. Астафьева // Academia: Педагогический журнал Подмосковья. - 2015. - № 2. - С. 59-62.

3. Астафьева, Е. Н. Современное учебно-методическое обеспечение преподавания истории педагогики в российских вузах / Е. Н. Астафьева // Историкопедагогический журнал. - 2015. - № 3. - C. 51-71.

4. Бёрк, П. Что такое культурная история / П. Бёрк ; пер. с англ. - М. : Издательский дом Высшей школы экономики, 2015. - 240 с.

5. Бим-Бад, Б. М. Что такое история педагогики? / Б. М. Бим-Бад // Современная российская история педагогики: методология изучения и теоретические подходы. - М. : АСОУ, 2014. - С. $11-14$.

6. Иллич, И. Освобождение от школ. Пропорџиональность и современный мир / И. Иллич ; пер. с англ., нем. - М. : Просвешение, 2006. - 160 с.

7. История педагогики Карла Шмидта, изложенная во всемирно-историческом развитии и в органической связи с культурною жизнью народов. Издание третье, дополненное и исправленное Вихардом Ланге. Перевод Эдуарда Џиммермана. Издание К. Т. Солдатенкова. Т. 1. История педагогики дохристианской эпохи. - М. : Типография А. И. Мамонтова и К울. 1877. - 500 с.
8. Константинова, Т. А. История горнозаводского образования в Забайкалье: 1723 - 1917 : дис. ... к.и.н. / Т. А. Константинова. - Чита, 2006 .216 с. (07.00.02 Отечественная история).

9. Корнетов, Г. Б. История педагогики как наука педагогическая и историческая / Г. Б. Корнетов // Педагогическая наука: генезис и прогноз развития: Материалы Международной научно-теоретической конференџии. Москва, 28-29 мая 2014 г., ИТИП РАО: в 2 ч. Ч. 1. - М. : ФГГНУ ИТИП РАО, 2014. - С. 9-38.

10. Корнетов, Г. Б. Педагогика как история педагогики / Г. Б. Корнетов // Историко-педагогический ежегодник. - M. : ACOУ, 2014. - C. 13-24.

11. Корнетов, Г. Б. Педагогика: теория и история. 3-е изд., перер., доп. / Г. Б. Корнетов. - М. : АСОУ, 2016. $472 \mathrm{c}$.

12. Корнетов, Г. Б. Педагогические учения в историко-педагогическом процессе / Г. Б. Корнетов. - М. : АСОУ, 2015. -260 c.

13. Корнетов, Г. Б. Понимание педагогик как истории педагогики / Г. Б. Корнетов // Психолого-педагогический поиск. - 2013. - № 4 (28). С. 123-134.

14. Корнетов, Г. Б. Постижение истории педагогики / Г. Б. Корнетов. - М. : ACOY, 2014. - 152 c.

15. Корнетов, Г. Б. Теория истории педагогики / Г. Б. Корнетов. - М. : ACOУ, 2013. - 460 c.

16. Лахман, Р. Что такое историческая соџиология? / Р. Лахман ; пер. с англ. - М. : Издательский дом «Дело» РАНХиГС, 2016. - 240 с. 


\section{историко-педагогического}

17. Макарова, А. И. История женского образования в Якутии: Конеџ XIX - начало XX века : дис. ... к.и.н. / А. И. Макарова. - Якутск, 2002. - 146 с. (07.00.02 Отечественная история).

18. Манюхина, О. А. История богословского образования в Ранней Византии : дис. ... к.и.н. / О. А. Манюхина. - Белгород, 2013. - 186 с. (07.00.03 Всеобшая история).

19. Маркс, К. Восемнадцатое брюмера Луи Бонапарта / К. Маркс // Маркс К., Энгельс ФФ. Сочинения. Т. 8. - М. : Госполитиздат, 1957. - С. 115-217.

20. Патраева, М. Н. Общеобразовательные школы города Стерлитамака Башкирской АССР в 1946-1978 гг. : дис. ... к.и.н. / М. Н. Патраева. - УФа, 2007. - 222 с. (07.00.02 Отечественная история).

21. Робинсон, К. Школа будушего. Как вырастить талантливого ребенка / К. Робинсон, Л. Ароника ; пер. с англ. - М. : Манн, Иванов и Фрербер, 2016. $-368 \mathrm{c}$.

22. Рубинштейн, М. М. История педагогических идей в ее основных чертах. 2-е изд. / М. М. Рубинштейн. Иркутск: Типография Дом Трудяшихся, 1922. -304 c.

23. Теория и методология исторической науки. Терминологический словарь / отв. ред. А. О. Чубарьян. - М. : Авилон, 2014. - 576 c.

24. Томас, Г. Образование: Очень краткое введение / Г. Томас ; пер. с англ.
- М. : Издательский дом Высшей школы экономики, 2016. - 176 с.

25. Ушинский, К. Д. О пользе педагогической литературы / К. Д. Ушинский // Ушинский К. Д. Проблемы педагогики. - М. : Издательство УРАО, 2002. - C. 13-31.

26. Ушинский, К. Д. Педагогическая антропология: Человек как предмет воспитания. Опыт педагогической антропологии. Ч. 1. / К. Д. Ушинский. - М. : Издательство УРАО, 2002. - 512 с.

27. Ушмаева, К. А. Основные этапы и особенности развития исторического образования в вузах России (20-90е годы $\mathrm{XX}$ века) : дис. ... д.и.н. / К. А. Ушмаева. -Пятигорск, 2011. - 562 c. (07.00.02 Отечественная история).

28. Ф / А. Я. с рология / отв. ред. Э. А. Шулепова. М. : Академический проект; Альма Матер, 2015. - С. 284-286.

29. с Миер, А. Я. Историческая культурология как область знания / А. Я. Ф логия / отв. ред. Э. А. Шулепова. - М. : Академический проект; Альма Матер, 2015. - C. 9-18.

30. Шулепова, Э. А. Культурология и ее исторические основания / Э. А. Шулепова // Историческая культурология / отв. ред. Э. А. Шулепова. - М. : Академический проект; Альма Матер, 2015. - С. 5-9. 


\title{
МЕТОДИКА ПРЕПОДАВАНИЯ
}
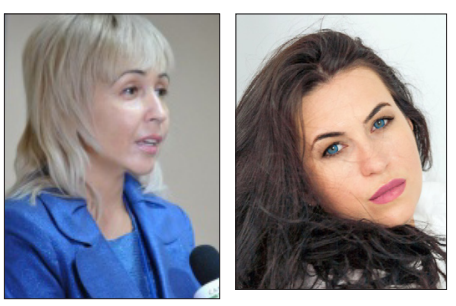

С. А. Севенюк,

Т. А. Парфенова

МОДУЛЬНО-РЕЙТИНГОВАЯ ПОДГОТОВКА БУДУЩИХ

ПЕДАГОГОВ ПО

ДИСЦИПЛИНЕ «ИСТОРИЯ

ОБРАЗОВАНИЯ И

ПЕДАГОГИЧЕСКОЙ МЫСЛИ

В РОССИИ И ЗА РУБЕЖОМ»

УДК 387.1

ББК 74.489.025.4

В статье представлен вариант модульно-рейтинговой системы при подготовке студентов по дисџиплине «История образования и педагогической мысли в России и за рубежом», анализируются принџипы модульного обучения, особенности его применения в подготовке будуших педагогов.

Ключевые слова: история образования и педагогической мысли; модульное обучение; рейтинговая технология; подготовка будуших педагогов.

\author{
S. A. Sevenyuk, \\ T. A. Parfyonova
}

\section{Module-rating training OF Future TEACHERS IN THE DISCIPLINE «HISTORY OF EDUCATION AND PEDAGOGICAL THROUGHT IN RUSSIA AND ABROAD»}

This article is devoted modular and rating training of students on discipline «History of education and pedagogical thought in Russia and abroad». The principles of modular training, his feature in training of future teachers are considered.

Key words: history of education and pedagogical thought; modular training; rating technology; training of future teachers. 
Система образования является основой инноваџионного развития экономики, промышленности и культурного потенџиала страны. Система высшего образования в современной России активно реформируется и модернизируется: пересматриваются как фундаментальные аспекты подготовки будущих профессионалов, так и прикладные технологии и методики обучения студентов. Повышение доступности качественного образования является стратегической целью государственной политики, в рамках которой разработаны и активно реализуются многие государственные программы: «Конџепџия Федеральной џелевой программы развития образования на 2016-2020 годы» ${ }^{1}$; «Конџепџия модернизаџии российского образования на период до 2020 года» $^{2}$, изменен и дополнен Федеральный закон «Об образовании в Российской Федераџии» ${ }^{3}$, утверждены новые федеральные государственные образовательные стандарты ${ }^{4}$.

На сегодняшний день используется џелый ряд инноваџий в развитии российской образовательной системы, к которым можно отнести такие, как реализаџия компетентностного и системно-деятельностного подхода; введение дистанџионно-тьюторского образования; многоаспектная реализаџия принџипов непрерывности и преемственности в образовании и т. д. Особый интерес для системы образования по направлению подготовки 44.00.00 «Образование и педагогические науки» представляет модульно-рейтинговая система.

Модульное обучение возникло в 60-х гг. XX столетия и активно применялось в США, ФФРГ, Англии, Российской Федераџии как средство систематизаџии учебной деятельности студентов, помогающее достичь четко определенных џелей. Семантический смысл термина «модульное обучение» связан с понятием «модуль», одно из значений которого - функџиональный узел. В этом контексте он понимается как основное средство модульного обучения, законченный блок информаџии. Теория модульного обучения широко освещена в исследованиях А. А. Вербиџкого ${ }^{5}$, В. М. Гареева ${ }^{6}$, П. Юџявичене ${ }^{7}$ и др. Модуль, от латинского modulus - «мера», предназначен развивать

1 Концепция Федеральной целевой программы развития образования на 2016-2020 годы. URL: http://government.ru/docs/16479/ (дата обращения 05.07.2016).

${ }^{2}$ Концепция модернизации российского образования на период до 2020 года. URL: http:// www.stgau.ru/cuko/docs/koncepcija1620.pdf (дата обращения 05.07.2016).

3 Федеральный закон «Об образовании в Российской Федерации». URL: http://www. consultant.ru/document/cons_doc_LAW_140174/ (дата обращения 05.07.2016).

${ }^{4}$ Федеральный государственный образовательный стандарт высшего образования URL: http://fgosvo.ru/fgosvo/92/91/4/94 (дата обращения 05.07.2016).

${ }^{5}$ Вербицкий А. А. Активное обучение в высшей школе: контекстный подход. М.: Высшая школа, 1991. $207 \mathrm{c.}$

${ }_{6}^{6}$ Гареев В. М. Принципы модульного обучения // Вестник высшей школы. 1997. № 8. C. 30-33.

${ }^{7}$ Юиявичене П. А. Теория и практика модульного обучения. Каунас: Швиеса, 1989. 272 с. 
мышление, осознание человека, воспитать способность и готовность к самостоятельному изучению. Модуль - это автономная организаџионно- методическая структура учебной дисџиплины, включающая в себя дидактические џели, логически завершенную единиџу учебного материала, методическое руководство и систему контроля ${ }^{1}$.

Принџипы модульного обучения были сформулированы Д. В. Чернилевским $^{2}$, а также уточнены И. Л. Дульчаевой ${ }^{3}$ :

1. Принџип модульности. Построение учебного проџесса согласно данному принџипу обеспечивает вариативность подготовки студентов в зависимости от уровня усвоения программы, что отображает главным образом индивидуализаџию образования.

2. Принџип структурирования. Учебная программа разбивается на определенные модули, которые соответствуют системе взаимосвязанных џелей. Каждый студент четко осознает, к какой џели он идет, осваивая тот или иной модуль дисџиплины.

3. Принџип гибкости. Стержень технологии модульного обучения мобильность и способность адаптироваться к меняюшимся условиям образовательного проџесса.
4. Принџип оперативности. Своевременный контроль и оценка әффективности модуля являются залогом успешной обратной связи корректировки учебной программы дисџиплины.

5. Принџип паритетности. Данный принџип обеспечивает осуществление учебного проџесса на основе субъект-субъектных отношений между преподавателем и студентом.

Основным существенным отличием модульного обучения от традиџионного является содержание образования, которое определяется современными потребностями рынка труда и личности будушего профессионала.

Вопросам модульного обучения в высшей школе и профессиональной подготовке в 90-е годы были посвящены работы Г. В. Лаврентьева и Н. В. Лаврентьевой ${ }^{4}$, а П. А. Юџявичене разработана конџепџия модульного обучения, а также проведен сравнительный анализ подготовки студентов в вузах на основе модульной системы $^{5}$. Проведенный анализ демонстрирует вариативность в понимании сути модульного обучения, однако большинство исследователей сходятся во мнении, что модуль - это логическая завершенность обучения, сегмент самостоятельной работы студента и ее тьюторское сопровождение.

\footnotetext{
${ }^{1}$ Коджаспирова Г. М., Коджаспиров А. Ю. Педагогический словарь: Для студ. высш. и сред. пед. учеб. заведений. М.: Издательский центр Академия, 2000. 176 с.

2 Чернилевский Д. В. Педагогика высшей школы. М : Машиностроение, 2005. 702 с.

${ }^{3}$ Дульчаева И. Л. Модель развития учебно-познавательной компетентности будущих педагогов профессионального обучения на основе модульно-рейтингового обучения // Вестник Бурятского государственного университета. 2015. № 15. С. 35-38.

${ }^{4}$ Лаврентьев Г. В., Лаврентьева Н. Б Слагаемые технологии модульного обучения: учеб.метод. пособие. Барнаул : изд-во АГУ, 1994. 128 с.

${ }_{5}^{5}$ Юиявичене П. А. Принципы модульного обучения // Советская педагогика. 1990. № 1. C. 55-60.
} 
Модульное обучение имеет свои особенности:

1. Студент - активный субъект своей учебной деятельности. Каждый студент самостоятельно осушествляет все этапы познания той или иной учебной дисџиплины: от џелеполагания до анализа собственных результатов и корректировки методов и приемов учебной работы. Преподаватель выполняет функџию тьютора: сопровождает и консультирует, тогда как главным ориентиром в проџессе познания является сам модуль.

2. Обеспечение самостоятельной подготовки студентов по дисџиплине, что позволяет формировать активно развивающуюся личность.

3. Содержание обучения представляется в законченных самостоятельных комплексах (информајионных блоках), дидактическая џель формируется для студента и содержит в себе не только указания на объем изучаемого содержания, но и на уровень его усвоения. Кроме этого, каждый студент получает информаџию, как раџиональнее действовать, где найти нужный учебный материал; каждый компонент дидактической системы (цели, содержание, способы управления учебным проџессом) проработан и наглядно представлен в модульной программе.

4. Содержание четко структурировано, теоретический материал изложен последовательно, учебный проџесс оснащен методическими материалами, а также системой контроля и оџенки учебных достижений, которая позволяет своевременно корректировать проџесс обучения.

5. Проџесс обучения адаптирован к индивидуальным возможностям и запросам учашихся ${ }^{1}$.

Модульное обучение развивает самостоятельность студентов, прозрачные дидактические цели повышают мотиваџию студентов, развитая система контрольно-измерительных материалов снижает стрессовую нагрузку, студенты становятся активными субъектами в построении собственной модели профессионального роста.

К главным достоинствам модульного обучения относятся:

1. Создание психологически безопасной среды в образовательном пространстве вуза за счет изменения функџий преподавателя с коррекџионно-оџеночной на консультаџионнокоординируюшую.

2. Развитие самостоятельности студента как залога профессионального самосовершенствования.

3. Варьирование модулей учебной программы, позволяюшие интегрировать и дифференџировать содержание учебного материала, группировать модули в полном, сокрашенном или углубленном вариантах.

4. С тимулирование учебно-познавательной активности студентов.

Неотъемлемой частью модульного обучения признан рейтинговый контроль знаний, обеспечивающй квалиметрическую оџенку уровня обученности студентов. Рейтинговая

${ }^{1}$ Дульчаева И. Л., Маланов И. А. Роль модульного обучения в развитии самостоятельной деятельности студентов // Вестник Бурятского государственного университета. 2014. № 1-3. C. 26-30. 
система контроля - суммарная (накопительная) количественная система оџенивания качества обученности студента по отдельному предмету, группе предметов, изучаемых в семестре, и в целом по дисџиплинам ${ }^{1}$. В вузовской практике рейтинг - это интегральная оџенка в баллах всех видов деятельности студентов, являющаяся количественной характеристикой качества учебной работы. Џелью рейтинговой системы оџенки успеваемости студентов является комплексная оџенка качества учебной работы студентов при освоении ими основных образовательных программ. Главная задача рейтинга заключается в повышении мотиваџии студентов к освоению образовательных программ путем более высокої дифференџиаџии оџенки их учебной работы, а также в повышении уровня организаџии образовательного процесса ${ }^{2}$.

Рейтинговая технология не отменяет и не противоречит традиџионной системе зачетов и экзаменов. Полный рейтинг дисџиплины определяется ее трудоемкостью (аудиторные занятия, самостоятельная учебная работа студентов), а работа преподавателей и студентов в условиях рейтинговой технологии регламентируется положением о рейтинговой подсистеме и организаџионно-методическими ре- комендаџиями. Рейтинговая система включает два взаимосвязанных проџесса: организаџию обучения и систематический контроль за его ходом во время учебных занятий.

Высокий рейтинг - это «...оџенка не только учебной деятельности студента, но и его самого, проявившего необходимые качества характера. Этот момент обучения нужно всегда акџентировать, выделять и широко рекламировать среди студентов». Одно из достоинств рейтинговой подсистемы - свобода самостоятельного изучения материала на уровне собственных возможностей студента без психофизических перегрузок. Рейтинг - это не только способ оџенивания и контроля успеваемости, он представляет собой систему организаџии учебного проџесса ${ }^{3}$.

Рейтинговая система в управлении самостоятельной учебно-познавательной деятельностью студентов имеет ряд положительных моментов:

1. Контроль самостоятельной работы студентов становится систематическим: осушествляется текушая, рубежная и итоговая оџенка.

2. Оџенка знаний - более объективной, итоговая отметка отражает адекватный уровень обученности студента, значительно меньшее влияние оказывают случайные факторы,

\footnotetext{
${ }^{1}$ Абрамов Я. Б., Головина И. В., Сущенко М. И. Опыт использования модульно-рейтинговой системы в СКФ МТУСИ // В сборнике: Университетский комплекс как региональный центр образования, науки и культуры: Материалы Всероссийской научно-методической конференции. 2014. С. 2805-2809.

${ }^{2}$ Ваганова В. И. Рейтинговая система контроля: Теория и методика обучения физике: учебное пособие. Улан-Удэ : Издательство Бурятского госуниверситета, 2004. 72 с.

${ }^{3}$ Дульчаева И. Л. Развитие учебно-познавательной компетентности студентов при обучении инженерной графике на основе модульно-рейтингового обучения // Вестник Бурятского государственного университета. 2014. № 1-1. С. 81-84.
} 
стрессовая ситуаџия экзамена, личностные отношения с преподавателем, сравнение с ответом более подготовленного студента.

3. Работа студента оџенивается по всем темам и видам деятельности, поэтому самостоятельное учение становится регулярным; активизируется познавательная деятельность студентов.

4. У студентов формируется самоконтроль, самооџенка.

5. Значительно повышается дисџиплина, снижаются пропуски занятий.

В Самарском государственном соџиально-педагогическом университете уже несколько лет ведется подготовка студентов с использованием модульно-рейтинговой системы.

Согласно Положению о модульно-рейтинговой системе подготовки студентов СГСПУ, џель модульнорейтинговой системы - повышение качества образования в условиях двухуровневой системы подготовки студентов при реализаџии требований ФГОС высшего образования по соответствуюшим спеџиальностям (направлениям подготовки). К основным задачам модульно-рейтинговой системы в СГСПУ относятся: обеспечение качества обучения студентов через определение образовательных результатов и создание системы оџеночных средств контроля результатов обучения; повышение качества образования за счет интенсификаџии учебного проџесса, активизаџии работы профессорско-преподавательского состава по обновлению и совершенствованию методов обучения, создания условий, обеспечивающих осознанность студентами проџесса обучения; осушествление регулярного контроля и рейтинговой оџенки качества обучения студентов при освоении ими основной образовательной программы по спеџиальности (направлению подготовки); обеспечение объективности в восприятии студентами оџенки их образовательных результатов по дисџиплине.

Модульно-рейтинговая система в СГСПУ предполагает три вида контроля студентов: входной, текущий и промежуточный. Студент изучает дисџиплину посредством трех видов деятельности: аудиторная, самостоятельная обязательная, а также самостоятельная на выбор студента. Информаџионной основой является балльно-рейтинговая карта, которую студент получает до начала занятий. Количество модулей в дисџиплине зависит от образовательных результатов, однако иногда определяется спецификой дисциплины. Модульнорейтинговая система СГСПУ предполагает развернутую консультаџионную работу преподавателя, что обеспечивает контроль всех видов деятельности студентов. Результаты всех видов учебной деятельности студентов оџениваются рейтинговыми баллами. Перевод баллов в академическую оџенку осуществляется по следующей схеме: оџенка «удовлетворительно» 56-70 \% баллов, «хорошо» 71-85 \% баллов, «отлично» 86-100 \% баллов. Сумма минимальных граниџ диапазонов всех дисџиплинарных модулей должна составлять 56 \% баллов, а максимальных $100 \%$ баллов. 
Модульно-рейтинговую подготовку по дисџиплине «История образования и педагогической мысли в России и за рубежом» студентов, обучающихся по профилям «Начальное образование и информатика»; «Начальное образование и иностранный язык»; «Начальное образование и дошкольное образование»; «Начальное образование и организаџия внеурочной деятельности»; «Психология и соџиальная педагогика» в Самарском государственном соџиально-педагогическом университете осушествляет профессорско-преподавательский состав кафедры психологии и соџиальной педагогики. Таким образом, кафедра реализует подготовку по данной дисџиплине согласно двум направлениям подготовки: 44.03.01 «Педагогическое образование» и 44.03 .02 « Психолого-педагогическое образование».

Дисџиплина «История образования и педагогической мысли в России и за рубежом» относится к базовой части учебного плана и реализуется на первом курсе в течение одного семестра. Основой реализаџии данной дисџиплины является рабочая программа учебной дисџиплины, ежегодно пересматриваемая и дополняемая. Трудоемкость данной дисџиплины в зачетных единиџах по направлению подготовки «Педагогическое обра- зование» составляет 2 единиџы (72 часа), по направлению подготовки «Психолого-педагогическое образование» 3 единиџы (108 часов) и предусматривает такие формы отчетности, как зачет в первом случае и экзамен во втором 1 .

Џелью данной дисџиплины является формирование системы историко-педагогических знаний, способности осознания студентами глубинных связей педагогических идей, явлений и фактов в их целостности и взаимодействии.

В качестве образовательных результатов по данной дисџиплине формируются следующие:

- по направлению подготовки «Психолого-педагогическое образование»:

ОК-2 - способность анализировать основные этапы и закономерности исторического развития общества для формирования гражданской позијии;

ОПК-4 - готовность использовать знание различных теорий обучения, воспитания и развития, основных образовательных программ для обучаюшихся дошкольного, младшего школьного и подросткового возрастов $^{2}$;

- по направлению подготовки «Педагогическое образование»:

\footnotetext{
${ }^{1}$ Основные образовательные программы высшего образования СГCПУ. URL: http://www. pgsga.ru/academy/structure/administration/ex_serv/educational-and-methodical/the_basic_ educational_programs/index.php (дата обращения 07.07.2016).

${ }^{2}$ ФГОС ВО по направлению подготовки 44.03 .02 «Психолого-педагогическое образование». URL: http://fgosvo.ru/uploadfiles/fgosvob/440302.pdf (дата обращения 07.07.2016). ФГОС ВО по направлению подготовки 44.03.01 «Педагогическое образование». URL: http:// fgosvo.ru/uploadfiles/fgosvob/440301.pdf (дата обращения 07.07.2016).
} 
ОК-2 - способность анализировать основные этапы и закономерности исторического развития для формирования патриотизма и гражданской позијии;

ОПК-4 - готовность к профессиональной деятельности в соответствии с нормативно-правовыми актами сферы образования.

Дисџиплина «История образования и педагогической мысли в России и за рубежом» состоит из двух логически завершенных блокмодулей: «История образования и педагогической мысли за рубежом» и «История отечественной педагогики». В проџессе освоения дисџиплины определяется рейтинг студента за качественное выполнение различных видов учебно-познавательной аудиторной и самостоятельной деятельности в рамках каждого модуля. Рейтинг студентов складывается из результатов учебной аудиторной работы, самостоятельной обязательной работы, самостоятельной работы на выбор студента, а также контрольных мероприятий. По каждому из этих видов работ осуществляется текуший и промежуточный контроль. Каждый модуль предусматривает контрольное мероприятие. Перед началом занятий студенты получают наглядное схематическое руководство по изучению дисџиплины, методические рекомендаџии, балльно-рейтинговую карту.

По модулям дисџиплины «История отечественной педагогики» используются такие образовательные технологии, как лекџия-визуализаџия, мультимедийная лекџия, проблемная лекџия, семинар-дискуссия, семинар- конференџия, брейнг-ринг, педагогическое проектирование. Освоение дисџиплины предполагает следующие образовательные продукты: конспекты лекций, конспекты первоисточников и хрестоматийных материалов, сравнительные таблиџы, хронологические таблиџы, рабочие тетради, учебный проект, доклады с мультимедийным сопровождением, публикаџия статей по историко-педагогической тематике.

По модулю дисџиплины «История образования и педагогической мысли за рубежом» текущий контроль складывается из следующих видов аудиторной работы: брейн-ринг по темам «Педагогика Античности», «Идеалы воспитания в эпоху Средневековья и Возрождения», участие в семинаредискуссии «Утопическая педагогика», участие в семинаре-конференџии «Становление научной педагогики», «Педагогика Просвещения», зашита учебных проектов на тему «Зарубежная педагогика XX века»; что в совокупности позволяет набрать студентам до $10 \%$ баллов за освоение дисџиплины. Самостоятельная обязательная работа по данному модулю дисџиплины предполагает выполнение таких видов учебной работы, как сравнительный анализ воспитательных систем Древней Греџии, конспектирование хрестоматийных материалов ( С равнительные жизнеописания» Плутарха, «Протагор» Платона, «Политика» Аристотеля, «О воспитании оратора» М. Ф. Квинтилиана,

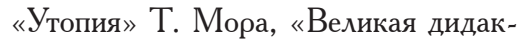
тика» Я. А. Коменского, «О воспитании джентльмена» Дж. Локка, 
«Эмиль, или О воспитании» Ж. -Ж. Руссо и др.), сравнительный анализ педагогических теорий эпохи Просвешения, подготовка докладов на различные темы модуля, подготовка учебного проекта на тему «Зарубежная педагогика XX века»; что в совокупности позволяет набрать студентам до $15 \%$ баллов за освоение дисциплины.

Самостоятельная работа на выбор студентов предполагает выполнение таких заданий, как подготовка доклада с мультимедийным сопровождением, публикаџия статей по историко-педагогической тематике в региональных и всероссийских научно-исследовательских конференџиях. Выполнение студентами самостоятельной работы на выбор позволяет набрать до 15 \% баллов по модулю, и до $30 \%$ по дисџиплине в џелом, что отвечает требованиям Положения СГСПУ о модульно-рейтинговой системе. Промежуточный контроль по данному модулю осуществляет ся в форме итогового тестирования и позволяет студентам набрать до 5 \% баллов. Таким образом, по данному модулю дисџиплины студент может набрать до 50 баллов, однако для успешного окончания освоения данной дисџиплины студенту необходимо набрать 28 баллов.

По модулю дисџиплины «История отечественной педагогики» текуший контроль складывается из следуюших видов аудиторной работы: брейн-ринг по темам «Просвешение в Киевской Руси», «Просветительские реформы начала XVIII века», «Развитие педагогической мысли в России во второй половине XVIII века», участие в семинаре-дискуссии по теме «Создание системы школьного образования в Советской России», участие в семинаре-конференџии на тему «Революџионно-демократические педагогические идеи», защита учебных проектов на тему «Воспитание и система народного образования в России в $\mathrm{XX}$ веке»; что в совокупности позволяет набрать студентам до $10 \%$ баллов за освоение дисџиплины.

Самостоятельная обязательная работа по данному модулю дисџиплины предполагает выполнение таких видов учебной работы, как выполнение хронологической таблиџы на тему «Поэтапное развитие школьного дела в России», сравнительный анализ педагогических взглядов И. И. Бејкого, Н. И. Пирогова, Н. А. Добролюбова, Н. К. Крупской и др., конспектирование первоисточников («О народности в общественном воспитании» К. Д. Ушинского, «Опыт яснополянской школы» $\mathcal{A}$. Н. Толстого), подготовка докладов на различные темы модуля, подготовка учебного проекта на тему «Воспитание и система народного образования в России в $\mathrm{XX}$ веке»; что в совокупности позволяет набрать студентам до 15 \% баллов за освоение дисџиплины. Самостоятельная работа на выбор студентов предполагает выполнение таких заданий, как подготовка доклада с мультимедийным сопровождением на тему «Соџиальное воспитание в Советской России», публикаџия статей по историко-педагогической тематике в региональных и всероссийских научно-исследова- 
тельских конференџиях. Выполнение студентами самостоятельной работы на выбор позволяет набрать до 15 \% баллов по модулю и до 30 \% по дисџиплине в џелом. Промежуточный контроль по данному модулю также осушествляется в форме итогового тестирования и позволяет студентам набрать до 5 \% баллов.

Рейтинговый контроль студентов осушествляется в течение всего семестра и доступен для каждого студента в онлайн системе LMS Moodle PGSGA $^{1}$, а также на офиџиальном сайте СГСПУ в разделе «Балльнорейтинговая система оџенки знаний» ${ }^{2}$. Таким образом, каждый студент может отслеживать и корректировать успеваемость по дисџиплине, а также планировать свое время с учетом индивидуального графика освоения џелей и задач учебной дисџиплины. В модульно-рейтинговой подготовке студентов по учебной дисџиплине «История образования и педагогической мысли в России и за рубежом» функџионирует система пооџрений и штрафных баллов. Поошрение в виде дополнительных баллов студенты могут получить за активное участие и победу в историко-педагогических Олимпиадах и конференџиях факультета, университета, а также других научно-исследовательских мероприятиях регионального, всероссийского и международного уровней. Система штрафных распространяется на те образовательные продукты студентов, уровень плагиата которых превышает 50 \%. Однако штрафные баллы не могут превышать более 10 \% от суммы баллов, набранных студентом за время освоения дисџиплины.

Таким образом, опыт модульнорейтинговой подготовки студентов по дисџиплине «История образования и педагогической мысли в России и за рубежом» позволяет выделить значимые акџенты в организаџии образовательного процесса: индивидуальный подход к итогам работы каждого студента; возможность дифференџированной оџенки всех видов работ студента; учет систематической и последовательной работы студента; контроль за степенью усвоения материала.

Модульно-рейтинговая подготовка позволяет развить у студентов организаџионные навыки, обучить методам учебно-исследовательской деятельности, способствует развитию способности к решению познавательно-практических задач, при этом проџесс обучения становится более интересным, так как позволяет студентам реализовать свои возможности, самостоятельно достигать конкретных целей в удобном для себя темпе. Совершенствование работы по подготовке будуших педагогов с использованием модульно-рейтинговой

\footnotetext{
1 Электронный ресурс дисциплины «История образования и педагогической мысли в России и за рубежом». URL: http://lms.pgsga.ru/enrol/index.php?id=16 (дата обращения 07.07.2016).

${ }^{2}$ Балльно-рейтинговая система оценки знаний СГСПУ. URL: http://www.pgsga.ru/academy/ structure/administration/ex_serv/educational-and-methodical/rating_system/ (дата обращения 07.07.2016).
} 
системы по дисџиплине «История образования и педагогической мысли в России и за рубежом» предполагает дальнейшую разработку методического инструментария, а также внедрение новых информаџионно-коммуникаџионных технологий, позволяющих осушествлять подготовку по дисџиплине не только в очной форме, но и дистанџионно.

\section{Список литературы}

1. Балльно-рейтинговая система оџенки знаний СГСПУ. URL: http://www. pgsga.ru/academy/structure/administration/ex_serv/educational-and-methodical /rating_system/ (дата обрашения 07.07.2016).

2. Ваганова, В. И. Рейтинговая система контроля: Теория и методика обучения физике: учебное пособие / В. И. Ваганова. - Улан-Удэ: Издательство Бурятского госуниверситета, 2004. - 72 с

3. Вербиџкий, А. А. Активное обучение в высшей школе: контекстный подход / А. А. Вербиџкий. - М. : Высшая школа, 1991. - 207 с.

4. Дульчаева, И. Л. Развитие учебнопознавательной компетентности студентов при обучении инженерной графике на основе модульно-рейтингового обучения / И. ᄉ. Дульчаева // Вестник Бурятского государственного университета. - 2014. № 1-1. - С. 81-84.

5. Конџепџия Федеральной џелевой программы развития образования на 2016-2020 годы. URL: http:// government.ru/docs/16479/ (дата обрашения 05.07.2016)

6. Положение о текущем, промежуточном контроле, промежуточной и итоговой аттестаџии студентов в условиях рейтинговой системы оџенивания результатов обучения. URL: http://ximgeosamara. ru/doc/eduproc/pol_con.pdf (дата обращения 07.05.2016).

7. ФГОС ВО по направлению подготовки 44.03.02 «Психолого-педагогическое образование». URL: http:/ / fgosvo. ru/uploadfiles/fgosvob/440302.pdf (дата обрашения 07.07.2016).

8. Чернилевский, Д. В. Педагогика высшей школы / Д. В. Чернилевский. - М. : Машиностроение, 2005. - 702 с

9. Юџявичене, П. А. Теория и практика модульного обучения / П. А. Юџявичене. - Каунас: Швиеса, 1989. -272 c.

10. Юџявичене, П. А. Принџипы модульного обучения / П. А. Юџявичене // Советская педагогика. - 1990. № 1. - C. 55-60. 


\title{
ИСТОРИЯ ОТЕЧЕСТВЕННОГО ОБРАЗОВАНИЯ И ПЕДАГОГИКИ
}

\author{
Е. Н. Астафьева \\ Институт школы \\ В ПЕДАГОГИЧЕСКОМ НАСЛЕДИИ \\ H. В. ЧЕХОВА
}

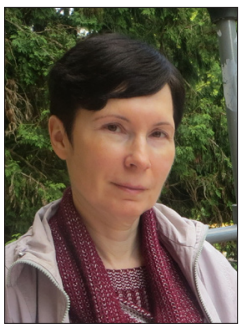

УДК 37(092)(091)

ББК 74.03(2)6-8 Чехов Н. В.

Н. В. Чехов (1865-1947) рассматривал школу как соџиальный институт, имеюший определенную структуру, функџии, режим работы, являюшийся образовательной организаџией, решаюшей учебные и во многих случаях воспитательные задачи. Идеалом школы для Н. В. Чехова в начале ХХ в. была свободная школа.

Ключевые слова: соџиальный институт; институт школы; Н. В. Чехов; российская школа; свободное воспитание.

E. N. Astafyeva

\section{THE INSTITUTION OF SCHOOL IN PEDAGOGICAL HERITAGE OF N. V. CHEKHOV}

N. V. Chekhov (1865-1947) saw the school as a social institution having a specific structure, functions, mode of operation, which also was an educational institution and solved training and educational tasks. At the beginning of the twentieth century the ideal school for N.V. Chekhov was a free school.

Key words: social institution; the institution of school; N.V. Chekhov; Russian school; free education.

Николай Владимирович Чехов (1865-1947) начал свою педагогическую деятельность в 1890 г. Он активно участвовал в обшествен- но-педагогическом движении, внес значительный вклад в развитие отечественного образования, занимался исследованиями в области школьного 
дела, методики обучения русскому языку и литературе, истории образования. Н. В. Чехов был одним из членов-учредителей и действительным членом Академии Педагогических Наук РСорР (1944). Н. В. Чехову посвяшена обширная литература, в которой исследуются различные стороны его педагогической и общественной деятельности, научного наследования ${ }^{1}$.

Значительное количество исследований Н. В. Чехов посвятил изучению проблем школы, осмысливая ее историю, современное состояние, перспективы развития ${ }^{2}$. В своих работах он во многих случаях трактовал школу как соииальный институт, хотя и не использовал самого этого термина. Обратимся к рассмотрению того, каким общественным институтом предстает школа в педагогическом наследии Н. В. Чехова, каким образом он характеризовал ее соџиальные и педагогические функџии, организаџионные особенности, какими типическими чертами он ее наделял.

По мнению В. И. Добренькова и А. И. Кравченко, «социальный инсmuтуm представляет собой: ролевую систему, в которую включаются также нормы и статусы; совокупность обычаев, традиџий и правил поведения; формальную и неформальную организајии; совокупность норм и учреждений, регулирующих определенную сферу общественных отношений; обособленный комплекс соџиальных действиї» ${ }^{3}$. Образование, как соџиальный институт, являет собой инс-

\footnotetext{
${ }^{1}$ См., например: Зенов М., Степанов С. Жизнь, отданная педагогике: к 100 -летию со дня рождения Н. В. Чехова // Учительская газета. 1965. 26 июня; Иванова Н. А. Педагогические взгляды Н. В. Чехова на проблемы российского учительства в контексте общественно-педагогического движения второй половины XIX - начала XX в. : дис. ... к.п.н. Воронеж, 2007. 222 с.; Медынский Е. Н. Старейший педагог Н. В. Чехов // Советская педагогика. 1945. № 9. С. 62-66; Седельникова М. В. Н. В. Чехов - видный деятель народного просвещения. М.: Учпедгиз, 1960. 172 с.; Смирнов О. Н. Академик Н. В. Чехов // Начальная школа. 1945. № 7-8. С. 47-49; Степанов С. Г. Чехов Николай Владимирович // Российская педагогическая энциклопедия: в 2 т. / гл. ред. В. В. Давыдов. М.: Большая Российская Энциклопедия, 1999. С. 568-569; Торгашова М. А. К 50-летию педагогической деятельности Н. В. Чехова // Советская педагогика. 1940. № 2. С. 109-110; Фотеева А. И. Педагог, ученый, общественный деятель Н. В. Чехов // Советская педагогика. 1986. № 2. С. 98-105; Шишонина Н. В. Деятельность Н. В. Чехова в годы советской власти // Страницы истории педагогики. Вып. 15. Пятигорск: ПГЛУ, 2000. С. 171-176; Шишонина Н. В. Общественно-педагогическая деятельность Н. В. Чехова до 1917 года // Страницы истории педагогики. Вып. 15. Пятигорск: ПГЛУ, 2000. С. 157-171 и др.

${ }^{2}$ См., например: Народное образование в России с 60-х годов XIX века / сост. Н. В. Чехов. М.: Польза; В. Антик и К , 1912. 224 с.; Чехов Н. В. Всеобщее обучение // Русская школа. 1906. № 12. С. 102-119; Чехов Н. В. Организация и задачи начальной школы // Вестник воспитания. 1905. № 1. С. 135-138; Чехов Н. В. Освобождение школы // Учитель. 1907. № 2. С. 1-4; Чехов Н. В. Свободная школа. Опыт организации средней школы нового типа. М.: Т-во И. Д. Сытина, 1907. 39 с.; Чехов Н. В. Типы русской школы в ее историческом развитии. М.: Товарищество «Мир», 1923. 149 с. и др.

${ }^{3}$ Добреньков В. И., Кравченко А. И. Фундаментальная социология: в 15 т. Т. V. Социальная структура. М.: ИНФРА-М, 2004. 1096 с. С. 182.
} 
титут преднамеренной соџиализаџии подрастающих поколений. Соџиолог С. А. Шаронова, выделяя три функџии образования (передачу џенностей, соџиальный контроль, структуролизаџия обшества), пишет: «Развитие ... института образования - это система сложного влияния общественных интересов на взаимодействие каждого компонента системы образования с гиперсистемой общества» 1 .

В современной справочной педагогической литературе школу определяют как «учебно-воспитательное учреждение, предназначенное для организованного обучения, воспитания и развития подрастающих поколений» ${ }^{2}$. По мнению историка педагогики М. А. Поляковой, «школа - это продукт историко-культурного развития общества, возникающий в результате выделения интеллектуального труда из сферы производства, соџиально санкџионированное (через легитимизаџию) средство реализации образовательных функиий общества (или образования) через учебно-воспитательную деятельность, подчиненную установленным (государством и обществом) правилам и стандартам; агент социализации личности» ${ }^{3}$.

Соџиологи В. И. Добреньков и В. Я. Нечаев указывают на необходимость различать понятия «об- разование» и «школа». Они пишут: «Образовательные институты (институџии) складываются и вне школы - там, где появляется необходимость спеџиальной подготовки индивида, где начинает функџионировать ролевая матриџа “учитель - ученик”, где появляется свой “дидактический арсенал”. Очаги образования имеются во всех сферах - производстве, семье, государстве и др. Но школа - особыї институт образования, характеризующйся следующими чертами: письменный текст как базовый объект обучения; общение в рамках институџиональной ролевой матриџы учитель - ученик, поддерживаемое собственным әтосом “учебного сообшества"; аудиторность и коллективное обучение как ближайшее средство интерсубъективного контекста сушностей-понятий и психологически комфортный механизм общения; дисџиплинарность в организаџии учебных занятий и сопутствующая ей конџептуализаџия программ обучения; наличие некоего общего стандарта обучения, который является предпосылкой легитимирующей функџии школы как соџиального института. Школа не создавалась в поле “чистого опыта”, она наследовала матриџы соџиализаџии предшествуюших культур и џивилизаџий» ${ }^{4}$.

\footnotetext{
${ }^{1}$ Шаронова С. А. Универсальные константы института образования - механизмы воспроизводства общества : автореф. дис. ... д. соц.н. М., 2005. 31 с. С. 19.

${ }^{2}$ Новейший психолого-педагогический словарь / сост. Е. П. Рапацевич. Мн.: Современная школа, 2010. 928 с. С. 878.

${ }^{3}$ Полякова M. А. Становление базовых моделей школ в Западной Европе в XVI веке / под ред. Г. Б. Корнетова. Калуга: ИП Стрельцов И. А. (Издательство «Эйдос»), 2016. 272 с. C. 51 .

${ }_{4}^{4}$ Добреньков В. И., Нечаев В. Я. Общество и образование. М.: ИНФРА-М, 2003. 381 c. C. 86.
} 
Н. В. Чехов утверждал, что «школа каждого народа есть органически раз вивающйся продукт его культурной жизни» ${ }^{1}$. По его мнению, «школа живет и развивается под влиянием двух главных факторов: во-первых, идеологического - роста культуры народа и в зависимости от тех задач, которые народ, в лиџе своего общественного мнения или своих верхних культурных или правящих слоев, ставит своей школе, и, во-вторых, материального, - то есть тех средств, которыми располагает народ, его обшественные организаџии или его государственная власть для осушествления этих задач. Сознательное отношение к школьному строительству требует полного исследования вопроса: какая школа нужна народу, общественным организаџиям и государству, и какими средствами они располагают для проведения в жизнь намеченной школы» ${ }^{2}$.

Отвечая на вопрос, что же представляет собой школа, Н. В. Чехов писал: «Мы можем дать школе такое определение: школа есть организованное учреждение, имеющее определенную образовательную иель и определенные формы и обгем работы учителя и учеников. Воспитательных задач школа может и не иметь» ${ }^{3}$. При этом он обращал внимание на то, что «школа не есть здание или помещение, где происходят занятия: она может и не иметь постоянного помещения и с переходом из одного помещения в другое - она не перестает быть школою. Собрание учеников тоже не составляет школы, ибо они ежегодно меняются, как листья на дереве, а школа остается. Школа остается тою же, когда в ней сменяется учитель» ${ }^{4}$.

По мнению Н. В. Чехова, классификаџии типов школ, прежде всего, могут различаться:

- по џелям, которые школы преследуют - во-первых, школы общеобразовательные или спеџиальные, и, во-вторых, школы, которые решают только образовательные или только воспитательные задачи;

- по формам их организации;

- по объему даваемого школами образования - начальные, средние, высшие;

- по характеру учебно-воспитательной работы - школы словесного или пассивного обучения и школы активного или трудового обучения (в начале $\mathrm{XX}$ в.);

- по соџиальному составу учашихся - всесословные школы и классовые школы.

Н. В. Чехов подчеркивал, что «тип школы определяется всей системой дела народного образования, задачами, которые ставит школе народ или отдельный его класс, который школа призвана обслуживать, и теми формами, в которые складывается

\footnotetext{
1 Чехов Н. В. Типы русской школы в ее историческом развитии. М.: Товарищество «Мир», 1923. 149 c. C. 3.

${ }^{2}$ Там же. С. 4.

${ }^{3}$ Там же. С. 10. (Курсив мой - Е. А).

${ }^{4}$ Там же. С. 9.
} 
школьная организаџия под влиянием культурных, бытовых и экономических условий своего сушествования. Для определения типа той или другой школы, необходимо знать следующие ее стороны: задачу школы, состав учашихся в ней детей, продолжительность обучения, план и программу сообщаемых знаний, квалификаџию учаших, организаџию школьного управления внутри школы; учебную обстановку школы, далее, ее отношение к населению и органам общей и учебной администраџии - и, наконеј, источники и способы ее материального обеспечения» ${ }^{1}$.

Для Н. В. Чехова џель школы «определяется современным моментом в истории развития идей истинного воспитания. Задачи воспитания в разные времена понимались различно. ... Частности этой задачи менялись с веками, но всегда в основе оставалась идея о необходимости сделать детей во всех отношениях такими же, какими являлись лучшие, наиболее уважаемые современники их родителей» ${ }^{2}$.

Н. В. Чехов подробно рассмотрел происхождение и значение термина школа. Проведенный им историколингвистический анализ значим и для современной педагогики. Он писал:

«Для обозначения того учреждения, которое мы чаще всего и в наиболее широком смисле слова называем школою, мы имеем в русском языке несколько слов: школа, училище, учебное заведение, гимназия, семинария, лицей, пансион. Если с учебным заведением соединялось и закрытое учреждение для воспитания учащиихся детей, то такие заведения назывались еще бурса, корпус, институт, пансион или сохраняли те же названия учебных заведений, но к ним прибавлялись слова “с интернатом”, "с пансионом”, “с общежитием”. Каждому из этих имен соответствовал особый тип школь, причем в разные эпохи одним и тем же именем назывались разные типь. Иногда данное учебному заведению название сохранялось за ним и после того, как самый тип его изменялся. Благодаря этому по названию не всегда можно судить о типе учебного или воспитательного учреждения. ... Древнейшее русское название для всякого учебного заведения было слово училище. ... Слово это, вероятно, появилось у нас вместе с введением письменности, появилось как новый термин нового понятия, перешедшего к нам от болгар вместе с циерковно-славянской письменностью. Оно соответствует греческому термину дидаскалион - обозначающему училище для мальчиков (или вообще для детей), где учитель (дидаскал) обучает их грамоте и музыке. Но корень греческого и русского язы-

\footnotetext{
${ }^{1}$ Чехов Н. В. Типы русской школы в ее историческом развитии. М.: Товарищество «Мир», 1923. 149 c. C. 11-12.

2 Чехов Н. В. Свободная школа. Опыт организации средней школы нового типа // Историко-педагогический ежегодник. 2010 год / Гл. ред. Г. Б. Корнетов. М.: АСОУ, 2010. C. $143-161$. С. 146.
} 
ка различен. Слово икола имеет длинную и поучительную историю. Слово это греческое (схолэ) и обозначает свободное время или досуг в переносном значении "способ использования этого досуга", то есть занятие чем-нибудь в свободное от главного занятия время. $B$ греческих гимназиях главным предметом занятия была гимнастика (откуда и самое слово), в программу гимназии вошли затем пение, музыка, декламация, танцुы. Свободное от этих обязательных занятий время юноши часто проводили в садах при гимназии. Сюда приходили представители старшего поколения, среди них уважаемые и умные люди, любители мудрости, то есть философь; юноши окружали их и охотно слушали их поучения и вели с ними беседы. Таким образом возникли “философские школь”, которые в Афинах носили названия по имени тех гимназий, в которых они собирались: Платон вел беседы в Академии, Аристотель - в Лицее (Ликей). ... Слово это перешло затем к римлянам, у которых оно стало обозначать, во-первых, ту или иную философскую систему (философская школа), во-вторьх, учреждение, в котором по большей части уже не дети, а взрослые обучались тому, чему обычно учили философь - грамматике, диалектике, риторике, математике, геометрии, музыке, медицине и другим наукам, входившим в курс тогдашнего философского образования, отличного и обособленного от курса начального обучения детей в дидаскалионе и от курса физической культурь и искусств в гимназии. Этот термин перешел от римлян к народам средневековой Европь и дал начало соответствующим в западноевропейских языках - французское еcole, немецкое schule (немеикое произношение латинского schola), итальянское scuоla, английское school, польское szcola и русское школа. По-видимому, русское слово прямо взято с польского вместе с самим понятием. Заимствование это

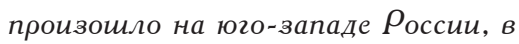
XVI в. так стали называться те “иколь”, которые устраивались православными братствами по образиу польских школ, с программой, общей для всех школ латинского Запада. Расширение понятия школа произошло гораздо позже. Оно шло различными путями в языке литературы и интеллигентного обиества и в языке народа. Однако для значительной части русского народа - для великороссов слово это до последнего времени оставалось чуждым, не всегда понятным, несмотря на широкое его распространение с кониа 80-х 22. XIX в. вместе с иерковно-приходскими школами. Другие начальные учебные заведения в деревне всегда назывались училищами. И только после Октябрьской революции 1917 г. слово “школа” стало офиииальным именем всех типов 
общесобразовательных учебных заведений первой и второй ступени (единая трудовая школа)» ${ }^{1}$.

В школе, являющейся образовательной организаџией, по мнению Н. В. Чехова, институализируются, воплошаются педагогические идеи. Он писал о том, что «общественная школа господствуюшего типа каждого народа и каждой эпохи отражает в себе общественно-педагогические идеи данного времени» ${ }^{2}$. При этом $\mathrm{H}$. В. Чехов исходил из того, что «всякая новая педагогическая идея зарождается обыкновенно вне непосредственной связи с практической деятельностью в школе. Школьные учителя слишком сживаются с приемами своего преподавания, которые для них лучше новых уже потому, что они к ним привыкли и лучше с ними справляются. Но зародившаяся в уме философа или даже писателя-художника новая педагогическая идея получает свое полное выражение только после того, как найдутся педагоги, которые попытаются испробовать ее на деле в школе. Школы этих педагогов обыкновенно не походят на школы господствуюшего в их время типа; большинству современников они кажутся странными, смешными. Но история дела народного образования учит нас относиться к таким опытам с особенным вниманием. Что казалось смешным и неисполнимым вчера, будет признано завтра и здравым и исполнимым» ${ }^{3}$.

Н. В. Чехов в своем понимании роли и места педагогических идей в развитии школ, как образовательных институтов общества, следовал той же логике, что и франџузский педагог и соџиолог Э. Дюркгейм (1858-1917). В статье «Природа и метод педагогики» Э. Дюркгейм выделял теоретические построения, цель которых «состоит не в описании или объяснении того, что есть, или что было, а в определении того, что должно быть. Они ориентированы не на настоящее, не на прошлое, а на будушее. Они не ставят себе цель верно отразить данную реальность, их џель - предписывать правила поведения. Они не говорят нам: вот что сушествует и каковы причины этого, но говорят: вот, что надо делать» ${ }^{1}$. Педагогика, по мнению Э. Дюркгейма, обдумывает системы образования ${ }^{5}$ для того, «чтобы дать деятельности воспитания идеи,

\footnotetext{
1 Чехов Н. В. Типы русской школы в ее историческом развитии. М.: Товарищество «Мир», 1923. 149 с. С. $6-9$.

2 Чехов Н. В. Свободная школа. Опыт организации средней школы нового типа // Историко-педагогический ежегодник. 2010 год / Гл. ред. Г. Б. Корнетов. М.: АСОУ, 2010. C. $143-161$. C. 143.

3 Чехов Н. В. Свободная школа. Опыт организации средней школы нового типа // Историко-педагогический ежегодник. 2010 год / Гл. ред. Г. Б. Корнетов. М.: АСОУ, 2010. С. $143-161$. С. 144.

${ }^{4}$ Дюркгейм Э. Социология образования / пер. с фр. М.: ИНТОР, 1996. 80 с. С. 38.

5 Э. Дюркгейм различал педагогику, занимающуюся поисками путей развития, совершенствования, обновления образования и воспитания, и науку о воспитании, которая, по его убеждению, исследовала существующую педагогическую деятельность. То есть для него педагогика являлась знанием о должном, наука о воспитании - знанием о сущем.
} 
которые направляют ее» ${ }^{1}$. Он писал: «Почти все великие педагоги Рабле, Монтень, Руссо, Песталоџџи - революџионные умы, восставшие против обычаев своих современников. Они упоминают о старых и сушествуюших системах лишь для того, чтобы осудить их, чтобы заявить, что у них нет основы в природе. Они их почти полностью разрушают и стараются построить на их месте нечто совершенно новое» ${ }^{2}$. Э. Дюркгейм рассматривал становление институтов образования как проџесс воплощения, «опредмечивания» в них педагогических идей, возникших в результате критики существующей педагогической реальности, поиска и осмысления ее желаемых форм под влиянием проџессов происходяџих в обшестве и культуре, экономической, соџиальной, политической, духовной деятельности людей.

Н. В. Чехов трактовал школу, как общественный институт, который в идеале должен осушествлять просвешение всего народа. Рассматривая ситуацию, сложившуюся в отечественном образовании в середине XIX в., Н. В. Чехов отмечал, что «деятельность воскресных школ была одним - правда, самым ярким, - из проявлений того стремления русского общества к просвешению народа, которое охватило лучшую его часть в конџе
50 -х годов» ${ }^{3}$. Он, более чем сочувственно относил к идее Н. А. Корфа, который, по словам Н. В. Чехова, указал «новое направление в сторону обогащения учащихся полезными знаниями и развития их природных способностей» ${ }^{4}$.

Вслед за К. Д. Ушинским, А. Н. Толстым, С. А. Рачинским Н. В. Чехов обращал особое внимание на потребность народа, значительнейшую часть которого составляло сельское население, в просвещении, которая ярко проявилась уже в середине $\mathrm{XIX} \mathrm{в.} \mathrm{и} \mathrm{заметно} \mathrm{усилилась} \mathrm{в} \mathrm{пос-}$ ледуюшие десятилетия. Н. В. Чехов, в частности, писал по этому поводу: «Самым ярким и убедительным свидетельством того, насколько народ сам уже тогда стремился к просвещению, служит то громадное участие, которое они принимали в устройстве и содержании земских школ в первое время их существования» 5 .

По мнению Н. В. Чехова, в 1880 х гг. в России џерковно-приходские школы «возникли в осуществление требований џентрального правительства и для проведения в жизнь желательных для него начал» ${ }^{6}$. Н. В. Чехов, характеризуя направленность деятельности џерковно-приходских школ, писал: «Школа должна больше воспитывать, чем учить, более сообщать навыков, чем знаний, больше

\footnotetext{
${ }^{1}$ Дюркгейм Э. Социология образования / пер. с фр. М.: ИНТОР, 1996. 80 с. С. 40.

2 Там же. С. 38.

3 Народное образование в России с 60-х годов XIX века / сост. Н. В. Чехов. М.: Польза; В.

Антик и К , 1912. 224 с. С. 20.

${ }_{4}^{4}$ Там же. С. 56.

${ }^{5}$ Там же. С. 31.

${ }^{6}$ Там же. С. 92. (Курсив мой - Е. А.).
} 
развивать религиозное чувство, чем ум ребенка. Такова была задача, поставленная џерковно-приходской школой» ${ }^{1}$.

Н. В. Чехов последовательно отстаивал необходимость всеобщего обучения народа, что требовало значительного расширения числа школ в Российской Империи. Под всеобшим обучением он понимал такую организађию школ, при котором начальное обучение становится фактически доступным для всего населения. Н. В. Чехов указывал, что в России вопрос о всеобщем обучении был по-настояшему поставлен только в 1860-е гг. ${ }^{2}$

В начале XX столетия Н. В. Чехов выступал последовательным сторонником свободного воспитания ${ }^{3}$, будучи в отличие от К. Н. Вентџеля представителем умеренного крыла этого педагогического течения. Он писал: «Только свободное воспитание человеческой души с самого детства может создать истинно свободных людей. Как свобода гражданская и политическая не предполагает вовсе прекрашения всех отношений между людьми и всегда и везде определяется известными граниџами, за которыми дальнейшее развитие личной свободы становится уже нарушением свободы другого человека, так и истинная свобода воспитания не предполагает полного прекрашения взаимных влияний между старшими и младшими поколениями, между воспитателем и воспитанником. Только из этого воспитания должно быть исключено все, что имеет характер физического или нравственного насилия» ${ }^{4}$. Н. В. Чехов высказывал мнение, согласно которому свободным воспитанием «может называться только свободное взаимодействие воспитателя и воспитанников, причем, безусловно, важно сохранить эту свободу как за той, так и за другой стороной. Рабство и угнетение вредно действует и действовало не только на угнетаемых, но и на угнетателей» ${ }^{5}$.

Н. В. Чехов следовал в педагогике идеалу естественного воспитания Ж.-Ж. Руссо. Вслед за великим женевцем Н. В. Чехов был убежден, что «воспитание должно идти согласно с природой, что его задача содействовать свободному росту и развитию естественных способностей и стремлений ребенка, что ребенок должен стать самим собою и ничем другим» ${ }^{6}$. Согласно әтому идеалу, Н. В. Чехов определял «џель обучения и воспитания в свободной школе. Џель эта создать для детей условия, наиболее благоприятствующие развитию их

\footnotetext{
${ }^{1}$ Там же. С. 100.

${ }^{2}$ См.: Чехов Н. В. Всеобщее обучение // Русская школа. 1906. № 12. С. 102-119.

${ }^{3}$ См.: Acтафьева E. Н. Свободное воспитание в России в конце XIX - первой четверти XX века // Историко-педагогический журнал. 2015. № 2. С. 80-99.

${ }^{4}$ Чехов Н. В. Свободная школа. Опыт организации средней школы нового типа // Историкопедагогический ежегодник. 2010 год / Гл. ред. Г. Б. Корнетов. М.: АСОУ, 2010. С. 143-161. C. 145 .

${ }^{5}$ Там же. C. 145.

${ }^{6}$ Там же. С. 146.
} 
природных наклонностей и духовных стремлений. Школа должна развить в них стремление к умственному, нравственному и физическому совершенствованию и дать им возможность беспрерывно и самостоятельно продолжать это совершенствование» 1 .

Для Н. В. Чехова идеал новой школы - «это идеал свободной школы, свободной не только от внешних враждебных истинному просвещению влияний - общественных и административных, но свободной по своему внутреннему строю, исключающему все признаки принудительности обучения ${ }^{2}$. При этом он указывал на то, что «следует строго различать истинную духовную свободу от свободы внешней политической и гражданской. Для громадного большинства людей последняя, правда, является необходимым условием и первой ступенью к освобождению духа, но политическая свобода сама еще духовной свободы в себе не содержит. Существуют на свете народы, пользуюшиеся очень свободными учреждениями, но живущие под страшным духовным гнетом общественных предрассудков, ложных идей, своекорыстных стремлений и даже моды» ${ }^{3}$.

Таким образом, Н. В. Чехов, рассматривая в своих работах школу, по сути, писал о соџиальном институте, имеющем определенную структуру, функџии, режим работы, являющемся образовательной организаџией, решающем учебные и во многих случаях воспитательные задачи. Согласно Н. В. Чехову, создание школы - это создание «учреждения, имеющего свои строго определенные формы, свои задачи и план своей деятельности» ${ }^{4}$. Он обрашал внимание на то, что «школа - это постоянно движушийся и развиваюшийся живой организм» ${ }^{5}$. Образ идеальной школы выражал стремление Н. В. Чехова создать такое образовательное пространство, которое бы максимально эффективно обеспечивало развитие природных дарований детей, их умственное, нравственное, физическое становление, позволяло учителям следовать логике их естественного роста.

\footnotetext{
${ }^{1}$ Там же. С. 147.

${ }^{2}$ Там же. С. 144.

${ }^{3}$ Чехов Н. В. Свободная школа. Опыт организации средней школы нового типа // Историко-педагогический ежегодник. 2010 год / Гл. ред. Г. Б. Корнетов. М.: АСОУ, 2010. C. $143-161$. C. 144.

${ }^{4}$ Там же. С. $145-146$.

${ }^{5}$ Там же. С. 147.
} 


\section{Список литературы}

1. Астафьева, Е. Н. Восхождение к истории педагогики / Е. Н. Астафьева // Academia: Педагогический журнал Подмосковья. - 2015. - № 2. C. 57-63.

2. Астафьева, Е. Н. Историко-педагогический контекст теории и практики современного образования / Е. Н. Астафьева // Academia: Педагогический журнал Подмосковья. - 2016. - № 4. C. 56-68.

3. Астафьева, Е. Н. Природа и свобода ребенка в отечественной педагогике первой трети XX века / Е. Н. Астафьева // Историко-педагогическое знание в начале III тысячелетия: педагогические направления в теории и практике образования: материалы Одиннадџатой Международной научной конференџии. Москва, 19 ноября 2015 г. / редактор-составитель Г. Б. Корнетов. - М. : АСОУ, 2015. C. 22-36.

4. Астафьева, Е. Н. Свободное воспитание в истории педагогики / Е. Н. Астафьева // Исторические пути развития образования и педагогики / под ред. Г. Б. Корнетова. - М. : АСОУ, 2015. - С. 110-139.

5. Астафьева, Е. Н. Свободное воспитание в России в конџе XIX - первой четверти XX века / Е. Н. Астафьева // Историко-педагогический журнал. - 2015. - № 2. C. 80-99.

6. Астафьева, Е. Н. Шенности гуманизма как образ хорошей школы первой трети XX века / Е. Н. Астафьева // Историко-педагогический журнал. - 2016. - № 1. - С. 115-129.

7. Добреньков, В. И. Фрундаментальная соџиология: в 15 т. Т. V. Соџиальная структура / В. И. Добреньков,
А. И. Кравченко. - М. : ИНФРА-М, 2004. - 1096 с.

8. Добреньков, В. И. Общество и образование / В. И. Добреньков, В. Я. Нечаев. - М. : ИНФРА-М, 2003. -381 c.

9. Дюркгейм, Э. Соџиология образования / Э. Дюркгейм; пер. с фр. - М. : ИНТОР, 1996. - 80 с.

10. Зенов, М. Жизнь, отданная педагогике: к 100-летию со дня рождения $\mathrm{H}$. В. Чехова / М. Зенов, С. Степанов // Учительская газета. - 1965. - 26 июня.

11. Иванова, Н. А. Педагогические взгляды Н. В. Чехова на проблемы российского учительства в контексте общественно-педагогического движения второй половины XIX - начала XX в. : дис. ... к.п.н. / Н. А. Иванова. - Воронеж, 2007. - 222 с.

12. Корнетов, Г. Б. Историко-педагогический контекст теории и практики современного образования: монография / Г. Б. Корнетов. - М. : АСОУ, 2016. -172 c.

13. Корнетов, Г. Б. История педагогики сегодня // Психолого-педагогический поиск. - 2013. - № 3. - С. 136-144.

14. Корнетов, Г. Б. История педагогических идей / Г. Б. Корнетов / / Психолого-педагогический поиск. - 2015. № 1. - C. 197-203.

15. Корнетов, Г. Б. Понимание педагогики как истории педагогики / Г. Б. Корнетов // Психолого-педагогический поиск. - 2013. - № 4 (28). - С. 123-134.

16. Корнетов, Г. Б. Теория истории педагогики: монография / Г. Б. Корнетов. - М. : АСОУ, 2013. - 460 с.

17. Медынский, Е. Н. Старейший педагог Н. В. Чехов / Е. Н. Медынский // 
Советская педагогика. - 1945. - № 9. C. 62-66.

18. Народное образование в России с 60 -х годов ХІХ века / сост. Н. В. Чехов. М. : Польза; В. Антик и К , 1912. 224 c.

19. Новейший психолого-педагогический словарь / сост. Е. П. Рапаџевич. Мн.: Современная школа, 2010. - 928 с.

20. Полякова, М. А. Становление базовых моделей школ в Западной Европе в XVI веке / M. А. Полякова: под ред. Г. Б. Корнетова. - Калуга: ИП Стрельџов И. А. (Издательство «Эйдос»), 2016. -272 c.

21. Седельникова, М. В. Н. В. Чехов - видный деятель народного просвешения / М. В. Сидельникова. - М. : Учпедгиз, 1960. - 172 с.

22. Смирнов, О. Н. Академик Н. В. Чехов / О. Н. Смирнов // Начальная школа. -1945. - № 7-8. - С. 47-49.

23. Степанов, С. Г. Чехов Николай Владимирович / С. Г. Степанов // Российская педагогическая энџиклопедия: в 2 т. / гл. ред. В. В. Давыдов. - М. : Большая Российская Энџиклопедия, 1999. - C. 568-569.

24. Торгашова, М. А. К 50-летию педагогической деятельности Н. В. Чехова / М. А. Торгашова / / Советская педагогика. - 1940. - № 2. - С. 109-110.

25. Фотеева, А. И. Педагог, ученый, общественный деятель Н. В. Чехов / А. И. Фотеева // Советская педагогика. - 1986. - № 2. - C. 98-105.

26. Чехов, Н. В. Всеобщее обучение / Н. В. Чехов / / Русская школа. - 1906. - № 12. - C. 102-119.
27. Чехов, Н. В. Организаџия и задачи начальной школы / Н. В. Чехов // Вестник воспитания. - 1905. - № 1. - C. 135-138.

28. Чехов, Н. В. Освобождение школы / Н. В. Чехов / / Учитель. - 1907. - № 2. -C. 1-4.

29. Чехов, Н. В. Свободная школа. Опыт организаџии средней школы нового типа / Н. В. Чехов. - М. : Т-во И. Д. Сытина, 1907. - 39 с.

30. Чехов, Н. В. Свободная школа. Опыт организаџии средней школы нового типа / Н. В. Чехов / / Историко-педагогический ежегодник. 2010 год / ГА. ред. Г. Б. Корнетов. -М. : АСОУ, 2010. C. 143-161.

31. Чехов, Н. В. Типы русской школы в ее историческом развитии / Н. В. Чехов. -М. : Товаришество «Мир», 1923. -149 c.

32. Шишонина, Н. В. Деятельность Н. В. Чехова в годы советской власти / Н. В. Шишонина // Страниџы истории педагогики. Вып. 15. - Пятигорск: ПГЛУ, 2000. C. 171-176.

33. Шишонина, Н. В. Общественнопедагогическая деятельность Н. В. Чехова до 1917 года / Н.В.Шишонина // Страниџы истории педагогики. Вып. 15. - Пятигорск: ПГЛУ, 2000. C. 157-171.

34. Шаронова, С. А. Универсальные константы института образования - механизмы воспроизводства обшества : автореф. дис. ... д-ра. соџ. наук / С. А. Шаронова. - М., 2005. - 31 с. 
В. Б. Помелов

\section{ВЫДАЮЩИЙСЯ ПРОСВЕТИТЕЛЬ ВЯТСКОЙ ЗЕМЛИ ЕПИСКОП ЛАВРЕНТИЙ ГОРКА}

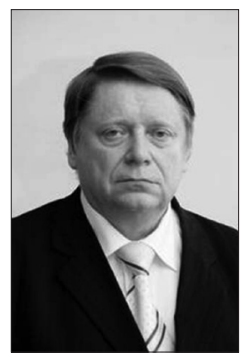

УДК 37(09)(470.342)

ББК 74.0392)5-218 Горка $ᄉ$.

В статье раскрывается содержание просветительской деятельности епископа Лаврентия Горки, создателя первой школы на Вятской Земле; показаны соџиально-политические условия, в которых проходия этот начальный этап просвешения.

Ключевые слова: Вятская Земля; император Петр I; императриџа Анна Иоанновна; Лаврентий Горка; Феофан Прокопович; М. Е. Ф иниџкий; Василий Лешинский; Иоаким Богомедлевский; Вятская славяно-латинская школа.

\section{B. Pomelov}

\section{भ̂n OUtstanding ENLIGHTENER OF THE VYATKA REGION THE BISHOP LAVRENTY GORKA}

In the article the educational activities of the bishop Lavrenty Gorka, the founder of the first school in the Vyatka region, are described. The socio-political conditions, which influenced the initial stage of the process of the enlightenment, are shown.

Key words: Vyatka region; the Emperor Peter the First; the Empress Anna Iohannovna; Lavrenty Gorka; Pheophan Prokopovich; M. E. Finizky; Vasily Leschshinsky; Ioakim Bogomedlevsky; the Vyatka Slavonic-Latin school.

Первые шаги по развитию государственного просвещения в России традиџионно связываются с деятельностью императора Петра I в первой четверти XVIII в. Образование, как составная часть петровских реформ, было вызвано к жизни важными соџиально-политическими и экономическими причинами, такими, как политическое лидерство дворянства; укрепление позиџий купечества и промышленников; складывание ре- 
жима абсолютизма; создание новой армии; трансформаџия системы государственного управления и появление большого количества чиновников. Преобразования требовали грамотных, образованных людей, которых в России крайне недоставало. Кроме того, на пути первых российских деятелей образования и просветителей было немало труднопреодолимых препятствий, среди которых необходимо выделить нехватку учителей, материальных средств, книг и учебных пособий, непонимание в местном обществе значимости образования, неготовность обывателей воспринимать «книжное учение».

$\mathrm{C}$ решением этих проблем не могли справиться люди, действовавшие, в лучшем случае, по приказу вышестоящего начальства, но в душе противившиеся нововведениям. Временем были востребованы духовные проповедники другого склада мыслей и образа действий, а именно яростные поборники петровских преобразований, настоящие борџы за дело просвещения. Таковым в историю Вятского края вошел епископ Вятский и Великопермский Лаврентий - (Горка), деятельность которого дала моџный толчок к развитию просвешения на Вятской Земле. Краткая по времени (1733-1737), но очень плодотворная деятельность Лаврентия Горки «на Вятке» оставила заметный след в местной истории, стала одним из главных региональных духовных событий XVIII в. Именно с созданной им здесь школы фактически ведет свой отсчет просвещение в этом крае.

Создание передовых для того времени учебных заведений, таких, как школа математических и навигаџионных наук, инженерная, артиллерийская и хирургическая школы, славяногреко-латинская академия и др. было характерным явлением для столичных городов - Москвы, Санкт - Петербурга и Киева. В провинџии же по-прежнему џарили отсталость и неграмотность; региональной образовательной среды как таковой практически не существовало, во многом и потому, что население в массе своей не видело большого смысла в овладении грамотностью. В то же время, согласно требованиям «Духовного регламента» (1721), составленного выдающимся общественным и религиозным деятелем петровской эпохи Феофаном Прокоповичем, уже предписывалось создавать архиерейские школы для детей духовенства.

Религиозное мировоззрение попрежнему оставалось доминирующим в общественном сознании, и данное обстоятельство во многом предопределило своеобразие создававшихся в тот исторический период школьных учреждениі. С одной стороны, это были русские школы, в которых преподавались учебные предметы на русском языке и был очень силен элемент православной религиозности. С другой стороны, школьные «фундаторы» должны были учитывать современные общественные веяния и изучать «европейские науки» (латынь, математика, история и география, начатки естествознания и пр.). Такой двойственный характер явственно прослеживается в деятельности первых вятских просветителей и, прежде всего, епископа Лаврентия Горки. 
Лаврентий (в миру - Андрей) Горка родился в 1671 г. в небольшом городке Лавров, близ г. Львова. По окончании Киево-Могилянской духовной академии, одного из крупнейших учебных заведений России того времени, он преподавал в нем вместе со своим другом Среофаном Прокоповичем (1681-1736), вел курс «пиитики» (с 1706 г.) и риторики (1708-1710 гг.). $\mathcal{~}$. Горкой была написана трагикомедия «Иосиф» (1708) на традиџионный библейский сюжет, составлен курс «пиитики» («Idea artes poeseos...», Киев, 1707). В своих учебниках Прокопович и Горка выражали любовь к лучшим произведениям античной литературы, приводили отрывки из произведений Вергилия, Гораџия, Овидия.

Хотя Горка был по возрасту старше Прокоповича, он смотрел на своего друга, вскоре ставшего ректором академии (в 1711 г.), а впоследствии и иерархом русской православной џеркви, «снизу вверх», считал его своим руководителем в науке, называл себя смиренно «братом во-вторых СDеофана Прокоповича». СD. Прокопович был одним из самых ярких сторонников преобразований Петра Великого. Нередко свои проповеди он посвяшал светским темам, например, прославлению побед русского оружия, восхвалению џаря-реформатора. Не забывал он и о необходимости просвешения.

В 1710 г. Л. Горку за отличие по службе утвердили игуменом Выдубиџкого монастыря в Киеве. В 1722 г. он стал архимандритом Воскресенского монастыря на Истре. В тот же год по ходатайству среофана Прокоповича Горка был приглашен в СанктПетербург и назначен обер-иеромонахом армии и флота. За свою ученость и усердие Горка заслужил особенное благоволение императора и 8 сентября 1723 г. был назначен епископом в Астрахань, где служил до 1727 г. Далее он служил епископом в Великом Устюге (1727-1731), Рязани (1731-1733) и, наконеџ, в Хлынове (1733-1737), - главном городе Вятской земли.

25 сентября 1733 г. императриџа Анна Иоанновна подписала указ о перемешении Рязанского архиерея Лаврентия Горки за его «продерзости» на Вятку, а Вятского архиерея Алексия Титова - в Рязань. На следуюший день Святейший Синод утвердил этот

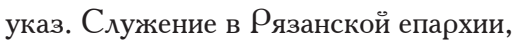
расположенной вблизи Москвы, считалось более почетным, в то время как город Хлынов уже тогда слыл местом ссылки, куда несколькими годами ранее был отправлен и архиерей Алексий Титов.

Торжественная встреча нового вятского владыки произошла 9 сентября в церкви Всех Святых. Хлыновџы были удивлены скорым приездом Лаврентия, последовавшим на пятый день после отъезда епископа Алексия. Лаврентий был архиереем совсем другого типа по сравнению со своими предшественниками. «Привыкшие к важным, тихим, размеренным движениям и речам старо-русских предместников, они (хлыновџы - В. П.) увидели перед собой характерного малоросса, были изумлены его подвиж- 
ностью, необыкновенной живостью его речей и жестов» ${ }^{1}$.

В ходе подготовки к открытию школы, первой в Вятском крае и в Предуралье, $\mathcal{~ \curlywedge . ~ Г о р к е ~ п р и ш л о с ь ~ с т о л - ~}$ кнуться со многими трудностями (отсутствие учебных пособиі, учительских кадров, средств, помещений и т. п.). Но самым большим препятствием было активное сопротивление со стороны части местного духовенства, закосневшего в невежестве и не желавшего получать в лиџе учащихся будущих конкурентов на занятие «лучших священнических мест». Епископу пришлось отрешать от должности священнослужителей, мешавших работе школы, причем в ряде случаев меру наказания определял Святейший Синод, к помощи которого Лаврентий Горка был вынужден прибегать.

Помощниками первого вятского просветителя оказались люди грубые и невежественные, которые в ответ на упреки и внушения Горки стали его открытыми врагами. Решительное противодействие Лаврентий Горка встретил даже там, где он был вправе ожидать помощи в первую очередь. 入иџа, стоявшие во главе хлыновского духовенства, такие, как архимандрит Успенского Трифонова монастыря Александр Корчемкин, протоиерей Троиџкой џеркви Артемон Шубин, ключарь Никита Клобуков не только высказывали прямое пориџание де- ятельности своего епископа, но первые двое даже самовольно оставили Хлынов и отправились в Святейший Синод с наветами на $\mathcal{\lambda}$. Горку.

Доносы на епископа продолжались в течение всего периода его деятельности в Хлынове. В ответ на это в «доношении» Святейшему синоду в мае 1834 г. он писал: «В многообразном и нестерпимом гонении от врагов, всесмиренно у Святейшего Синода прошу крепкого защищения и помощи, ибо за таким гонением нельзя мне и жить, не токмо епархиею управлять. Вси единодушно на мое зло настроены и разврашены, вси безмерно на соблазн прочим распустилися, вси не слушают; иные бегают, другие укрываются и неисповедимые пакости мне творят... Хотел я и учения славяно-латинския в епархии Вятской заводить и учителей из Киева двух человек мирских вызвал; но за таким гонением и противностями ждать доброго невозможно $»^{2}$.

Важным направлением деятельности епископа Лаврентия было «выправление» хозяйственного положения архиерейского дома, которое ко времени приезда $\mathcal{~}$. Горки в город Хлынов в 1733 г. было плачевным. От предшественника не осталось не только домовой денежной казны, но был долг в коллегию экономии в размере 529 р. 34 к. ${ }^{3}$

\footnotetext{
${ }^{1}$ Верещагин A. C. Эпизоды из жизни основателя Вятской семинарии. Эпизод V. Архиерейство на Вятке // Памятная книжка и календарь Вятской губернии на 1902 г. Вятка, 1901. С. 50-102. C. 56.

${ }^{2}$ Верещзагин А. С. История Вятской духовной семинарии // Вятские епархиальные ведомости. 1868 , № 1. С. 4-19. С. 18-19.

${ }^{3}$ Там же. С. 13.
} 
Тем не менее, новый епископ незамедлительно приступил к созданию школы. Для того чтобы иметь средства к обустройству школы, $\mathcal{\lambda}$. Горка разослал по всей епархии указ о том, чтобы попы, дьяконы, дьячки, пономари, сторожа и просворниџы «немедля» явились к нему «все необходно». ᄉ. Горка принимал являвшихся к нему духовных лиџ, подробно расспрашивал их о доходах и определял сумму, которую каждый из них беспрекословно должен был внести на содержание школы.

Он требовал, чтобы все монастыри и пустыни доставили «ни мало не медля» в архиерейский дом двадџатую долю хлеба, которую они должны были поставлять уже в течение десяти лет. Однако ни одно распоряжение епископа не было принято к исполнению быстро и охотно.

Священнослужители являлись «с великою неохотою и тое самое малое число», а остальные, в течение почти целого года, по ноябрь 1734 г. «вовсе не явливались». В 1734 г. двадџатой доли хлеба не передал ни один монастырь. Никто даже не представил ведомости о количестве хлеба, подлежашего «выделу» (то есть выделению) для нужд школы.

Неоценимую помощь Горке в этот период оказал виџе-президент (с 1721 г.) Святейшего Синода архиепископ Феофан Прокопович. При его содействии некоторые «закашики» были смешены. Александр Корчемкин, бежавший в Рязань после своего доноса на $\mathcal{~}$. Горку в Москве, был схвачен и казнен. Другие џерковнослужители, выказывавшие невнимание к указанием $\mathcal{~}$. Горки, были вызваны в крестовую палату и получили надлежащее «вразумление». В итоге, противостояние епископа Лаврентия и реакџионеров-священнослужителей на некоторое время ослабло.

Для лучшего учета $\curlywedge$. Горка завел ведомость прихода и расхода «и об остатке хлеба и денежной казны, собираемых с монастырей двадџатой доли на содержание семинарии». В ней по различным разделам указаны поступления хлеба в «четвертях» и «четвериках», денег - в рублях и копейках; отмечается, сколько следует купить овса, толокна, ржи, яровых и т. п. К 1735 г. уже большая часть духовенства внесла в архиерейскую казну деньги на содержание школы, а с начала 1735 г. стала вносить и «двадџатую долю». Тем самым, материальные средства для открытия школы были изысканы. Школа была устроена в архиерейском доме. Она размешалась в одной большой двухэтажной и трех небольших деревянных избах, находившихся внутри ограды архиерейского дома.

Непростыми были и поиски «годного для обучения студентов человека к себе на Вятку». Найти учителей оказалось делом нелегким. Киевские богословы крайне неохотно отзывались на приглашения архиереев занимать должности в провинџиальных школах. Между тем, $\mathcal{\Lambda}$. Горка в своем стремлении совершенствовать организаџию обучения устанавливал культурные и научные связи с известными џентрами просвещения и развития педагогической мысли. С этой џелью он пишет письмо в свою «альма матер» Киево-Могилянскую духовную ака- 
демию, которая, как отмечалось в его льстивом послании «изобиловала учеными людьми» и «от нея, аки от пресловутых оных Афин, вся Россия источник премудрости почерпает и вся своя новозаводимыя училишныя колонии напаяет и изращает. Академия Киевская еще умножит себе славу, егда и в Вятскую колонию извезет на жатву делателей и поможет собирать плоды богоугодные и душеспасительные» 1 .

Через посредничество священника Московского Благовещенского собора Иакова Буявинского, который «снесся с киевскими студентами», удалось пригласить в Хлынов студента класса философии Михаила Евстафьевича Финиџкого (около 1705 - после 1787). Он согласился приехать в Хлынов только тогда, когда получил согласие $\mathcal{\lambda}$. Горки на свои условия - годовое жалованье в 72 рубля². М. Е. ФФиниџкий приехал в Хлынов в апреле 1734 г. Именно M. Е. Финиџкого можно с полным основанием считать первым учителем на Вятской земле, а Лаврентия Горку - первым просветителем, первым организатором просвешения.

В тот же год появился и второй учитель из студентов Киево-Могилянской духовной академии - Василий ᄉещинский. Третьим учителем школы стал ученый иеромонах Иоаким Богомедлевский, обучавшийся в молодости в шести европейских университетах. По навету он был осужден и свое за- ключение отбывал в Пермской Земле, в Чердыни, в «Чюсовских городках», откуда $\mathcal{\lambda}$. Горка его и освободил.

Таким образом, проблема учительских кадров на первое время оказалась решенной. Первые учителя Вятской школы имели достаточно высокое для того времени образование, были гуманными и доброжелательными по отношению к детям наставниками. В школе были исключены физические наказания.

Особую заботу $\mathcal{\lambda . ~ Г о р к а ~ п р о я в л я л ~}$ о приобретении книг. Он составил реестр «книг латинских», которые закупались в Москве, Санкт-Петербурге, Киеве, Астрахани, Рязани, Великом

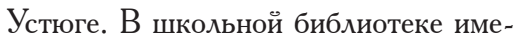
лись произведения Гомера, Данте, Џиџерона, Сенеки, Гораџия, Овидия, Петрония, Вергилия и других классических авторов, а также лучшие для того времени учебные пособия, например, учебники Эммануэля Альвара по началам латинского языка, так называемые «Альваровы рудименты».

Обязательное открытие при школах библиотек особо оговаривалось в «Духовном регламенте». Согласно одному из его положений, пользоваться книгами преподаватели и ученики должны были в спеџиальной «библиотечной конторе». Предусматривалась также выдача книг на дом. Вводилась регламентаџия работы библиотек («А ученикам и прочим охотникам отворять библиотеку в уреченные дни и часы»). Для архиерейских школ по

\footnotetext{
${ }^{1}$ Верещагин А. С. История Вятской духовной семинарии // Вятские епархиальные ведомости. 1868, № 1. С. 4-19. С. 12.

${ }^{2}$ Верещагин A. C. Ученый южнорусс на Вятке в XVIII в. // Памятная книжка и календарь Вятской губернии на 1895 г. Отдел IV. Вятка, 1894. С. 302-321. С. 315.
} 
всем епархиям было разослано 900 букварей и 920 грамматик, которые положили начало школьным библиотекам. ᄉ․ Горка отдал в школу все книги богатейшей для того времени своей личной библиотеки.

Составленная после смерти $\mathcal{\lambda}$. Горки опись его библиотеки включала 355 книг, причем две трети из них были на иностранных языках: на латинском, греческом, еврейском, польском. Третью часть составляли книги светского содержания - сочинения по истории, философии, филологии, риторике и географии, юридическая и художественная литература ${ }^{1}$. Некоторые рукописи из библиотеки школы, (впоследствии ставшей духовной семинарией), созданные преподавателями и учашимися сохранены и поныне. Кстати, в одном из конволютов, некогда принадлежавшем Горке, а ныне хранящемся в Кировской областной научной библиотеке им. А. И. Герџена, имеется прижизненное издание сочинений Т. Кампанеллы. Среди сохранившихся в «Герџенке» книг из школы $\mathcal{\lambda}$. Горки есть сборник упражнений в пиитике, включающий стихи преподавателей Вятской семинарии М. А. Ушакова и Г. С. Шутова ${ }^{2}$.
В семинарской библиотеке хранились стихотворные посвящения учеников важным событиям и отдельным лиџам. Оригинальные произведения содержит ученическая тетрадь Агафона Свешникова - будушего протоиерея Спасского собора, относяшаяся к середине XVIII в ${ }^{3}$.

Лучшая часть библиотеки семинарии, «за особливой их редкостию», была передана в 1741 г. в распоряжение Синода по его настоятельному требованию ${ }^{4}$. В Хлыновской школе остались, по данным описи 1739 г., 34 книги, а по другим данным - 42, переданные Горкой еще при жизни в школьную библиотеку 5 . Даже после смерти $\mathcal{\lambda}$. Горки в семинарию продолжали некоторое время приходить выписанные им «на суммы архиерейского дома» сочинения на латинском языке.

Теперь, когда задачи хозяйственного обеспечения работы школы, подбор учителей, приобретение книг были, в основном, завершены, дело стало за набором учашихся из детей «лучшего священства», многие из которых стремились в массе своей избежать учения. Духовенство считало отправку детей в школу своей самой

${ }^{1}$ Луппов С. П. Книга в России в послепетровское врмя. 1725-1740. Л., 1976. 420 с. С. $292-$ 293.

${ }^{2}$ Вятский архиерейский дом и архиерейские вотчины 1827 г. // Труды Вятской ученой архивной комиссии. Выпуски 1-2, отдел 3. Вятка, 1916.

3 Кудрявиев И. М., Шлихтер Б. А., Щапов Я. Н. Археографические экспедиции отдела рукописей Государственной библиотеки имени В. И. Ленина в 1953-1956 гг. М., 1956. C. 256-301. C. 256.

${ }^{4}$ Верещагин А. С. История Вятской духовной семинарии // Вятские епархиальные ведомости. 1868 , № 1. С. 4-19. С. 30 .

5 Кудрявцев И. М., Шлихтер Б. А., Щапов Я. Н. Археографические экспедиции отдела рукописей Государственной библиотеки имени В. И. Ленина в 1953-1956 гг. М., 1956. C. $256-301$. C. 278. 
тяжелой повинностью. ᄉ. Горкой было сделано распоряжение о «наборе робят» в архиерейский дом для помещения их в латинскую школу. $\mathrm{OH}_{\mathrm{H}}$ потребовал, чтобы все священнослужители привели к нему своих детей, начиная с семилетнего возраста «без малейшего замедления», под «опасением» самой строгой ответственности в случае утайки детей или медленного исполнения архиерейского указа.

«Духовным регламентом» и новым указом Анны Иоанновны (1731 г.) архиереям предлагалось брать в школы и детей «лучших градских детей», а «тех, которые из них в школе быть не похотят, имать в школы и неволею» ${ }^{1}$. Поэтому $\mathcal{~}$. Горка сделал распоряжение о наборе в школу детей лиџ гражданского ведомства и даже военных, находившихся тогда в ведении духовной власти. Однако поначалу всего несколько священнослужителей, и то из близлежаших к Хлынову монастырей, привели своих детей учиться; «остальные всеми возможными случаями старались укрыться от школы» ${ }^{2}$.

Большая часть «закашиков» (благочинных), на которых было возложено исполнение приказа о наборе детей, не подумали его выполнять и «во всем явились ослушны и указу противны». Например, из 110 священнослужительских детей Чердынского «заказа» не было направлено в школу ни одно- го в 1734-1735 гг. Провинџиальная канџелярия также не направляла в школу детей приказных и посадских ${ }^{3}$.

Подобное невнимание вятского общества к школе объяснялось низким духовным и материальным уровнем тогдашнего населения края, несформированностью региональной образовательной среды. Неприязненное отношение к проводимым реформам было намного сильнее выражено именно в глухой вятской провинџии, по сравнению с џентральными регионами России. «На Вятке» практически не было образованных людей, сторонников петровских реформ, да и о самих реформах люди имели самое смутное представление.

Важным препятствием на пути распространения просвешения выступало то, что люди в провинџии зачастую не видели ошутимой выгоды знаний. К тому же, если бы Горка заводил школу православно-славянскую, это нашло бы больше понимания у хлыновџев. Как-никак в то время «на Вятке» были грамотные люди, которые «ведали», что «издревле бы обычай детоводџем учити дети малыя - в начале азбуџе, потом часослову и псалтири, тоже писати». Поэтому по всей вероятности в случае открытия православно-славянской школы и не было бы такого сопротивления. Однако Горка «измыслил заводить» именно «школу латинскую», чтобы учить

\footnotetext{
${ }^{1}$ Верещагин А. С. История Вятской духовной семинарии // Вятские епархиальные ведомости. 1868 , № 1. С. 4-19. С. 14.

2 Преснечов Р. М. «Который первый здесь науки насадил» // Краеведческий сборник «Вятка» // под ред. Е. Д. Петряева. Киров, 1975. С. 107-112. С. 107.

${ }^{3}$ Верещагин А. С. История Вятской духовной семинарии // Вятские епархиальные ведомости. 1868 , № 1. С. 4-19. С. 16.
} 
в ней «неведомо каким» наукам. Во времена, когда практически все население не владело грамотой даже родного языка, учителя-«латыншики» не могли не вызывать неприязни. К тому же, изучение латыни воспринималось вятчанами как своего рода предпочтение католиџизма в ушерб православию.

Не ограничиваясь призывами, $\mathcal{\lambda .}$ Горка послал в конџе 1734 г. в «заказы» нарочных «розсыльшиков» и приставов духовного приказа для сыска укрываюшихся от школы, приказал привозить последних в Хлынов, а в случае сопротивления «вязать их», «заковывать в колодки» и отправлять партиями в архиерейский дом «за надлежашим караулом» .

В числе учащихся школы $\mathcal{\lambda}$. Горки, помимо детей протопопских, поповских, дьяконских, причетнических, сторожевских, просфирнических, были также дети подъячих архиерейского приказа, монастырских стряпчих, сержантов, поручиков и капитанов, живших при Успенском монастыре. По отношению к ним Горка употреблял те же самые «побудительные меры», что и по отношению ко всему духовенству в џелом. Он стремился к определению в школу детей и посадского сословия, составлявшего тогда почти исключительно все население г. Хлынова. Сначала он обычно действовал увешеваниями: приглашал к себе лиџ, «более значительных между посадскими», лично беседовал с ними о пользе учения, старался привлечь и самих детей посредством обещаний и подарков. В случае же неуспеха разговора прибегал к угрозам.

Подобное обрашение с детьми не было в то время чем-то чрезвычайным. Само правительство рекомендовало тогда такой способ действий. Поәтому Горка лишь выполнял указания верховной власти. Когда удавалось набрать несколько будущих школьников, «розсыльщики» ехали с ними в другое место, пока не набиралось 10-15 детей, которых и привозили в Хлынов, - если только те не успевали сбежать по дороге, - и сдавали под расписку в духовный приказ.

Столь решительные и грубые меры возбудили к Горке еше больший страх и ненависть со стороны некоторых обывателей. Тем не менее, к началу 1735 г. удалось собрать до четырехсот учеников в возрасте от 7 до 25 лет. Но ᄉ. Горка действовал не только кнутом, но и пряником. Он «побуждал духовых, в надежде лучшего священства», то есть обещая назначения в более богатые приходы, отдавать в школу своих детей, обязывая в назначенные сроки предварительно обучить их на дому пению, чтению и письму, «под опасением лишать непослушных священства и чинов» ${ }^{1}$. Однако самовольные побеги детей из школы не были редкостью. Тогда Горке снова приходилось посылать «розсыльшиков». Таким образом, используя методы принуждения и поощрения, $\mathcal{\Lambda}$. Горке удалось, несмотря на сильнейшее противодействие, в 1734 г. открыть школу. По отношению к учащимся своей школы Горка проявлял гуманность.

\footnotetext{
${ }^{1}$ Никитников Г. А. Иерархия Вятской епархии. Вятка, 1863. 214 с. С. 30.
} 
Тем не менее, условия содержания нельзя было признать благоприятными: дети проживали в холодных монастырских кельях, скудно питались и поэтому нередко убегали домой. За «утеклецами» снаряжалась погоня. Дети «недостаточных» родителей, не имевшие родственников в $\mathrm{X}_{\text {лынове, }}$ помещались на готовое содержание и получали питание, одежду и книги бесплатно. Но большая часть учеников была на содержании родителей и посещала школу только на время уроков.

ᄉ. Горка уделял большое внимание раџиональной организаџии работы школы, взяв при этом за образеџ свою «альма матер» - Киево-Могилянскую духовную академию. Это проявилось, прежде всего, в выборе предметов для обучения и особенностях построения учебного проџесса. После того как в первый учебный год «профессор» Финиџкий обучил учашихся «верхней школы» «Алваровым рудиментам», а «инспектор нижней школы» Лещинской с начинающими учениками одолел основы славянской грамоты, Горка уже со второго года работы школы выделил шесть классов, получивших названия по основному учебному предмету (фара, инфима, грамматика, синтаксима, пиитика, риторика).

Разумеется, различие между рассматриваемыми двумя учебными заведениями, одно из которых было школой в предуральском захолустье, а другое - учреждением российского масштаба, далеко не ограничивалось лишь отсутствием в вятской школе, в сравнении с Киевской академией, двух старших классов (философии и богословия), однако само стремление ᄉ. Горки ориентироваться на лучшие образџы при устройстве учебного заведения способствовало укреплению авторитета его школы, повышению качества обучения в ней и, несомненно, было одной из важнейших сторон его просветительской деятельности на Вятской земле.

Обладая жестким характером, ᄉ. Горка проводил, подобно Петру I, «варварскими методами борьбу против варварства», чем вызывал недовольство среди местного духовенства. Однако его деятельность, конечно, носила прогрессивный характер, за что он и получил впоследствии в народе почетное звание «просветителя Земли Вятской». Заложенный $\lambda$. Горкой интерес к чтению среди вятчан выразился, например, в том, что спустя несколько лет после его смерти и восстановления пришедшей было в упадок школы, за граниџей было выписано для семинарии книг «избранных џерковных и лучших классических писателей» на 1500 рублей. Система образования и воспитания в школе $\mathcal{\lambda}$. Горки закладывала в учениках понимание литературных џенностей, формировала вкус к творческим опытам. Учашимися переписывались и переводились с других языков отдельные учебные пособия, создавались даже оригинальные произведения, чему в значительной степени способствовали поддерживавшиеся в этом учебном заведении на протяжении всего периода его существования традиџии стихотворчества и «лиџедейства». 
Стремясь доставить детям «при-

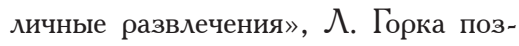
волял им в определенные дни и часы развлекаться играми как в самом архиерейском доме, так и во время прогулок за городом. В зимнее время, особенно перед праздниками, в школе разыгрывались духовные мистерии. Ученики школы участвовали в торжественных џерковных проџессиях. Воспитанники «разыгрывали действа»; в репертуар входила и трагикомедия самого $\mathcal{\lambda}$. Горки «Иосиф». Традиџии «школьной драмы» (то есть драматизајии) были продолжены и после его смерти в стенах Вятской духовной семинарии - преемниџы школы Ааврентия Горки, преподавателями 3. О. ᄉятушевичем и С. С. Леонтьевым в так называемых «разговорах» - своеобразных театрализованных диалогах о добре и зле, причем это имело место уже во второй половине XVIII в., в эпоху Просвещения ${ }^{1}$.

Основатель Хлыновской славянолатинской школы епископ $\mathcal{~}$. Горка и его соратники и последователи были, как показывает анализ их деятельности на Вятской земле, несомненно образованными и талантливыми людьми, стремившимися служить народу на ниве просвешения. Первый «фундатор» школы, по всей вероятности, был ознакомлен с лучшими достижениями педагогической практики европейских стран, в частности, с классно-урочной системой, которая, как известно, получив известность после Я. А. Коменского, вела, тем не менее, свое начало от братских школ Украины и Польши, то есть именно там, где прошла значительная часть жизни вятского просветителя.

Основным учебником во всех четырех классах был учебник Эммануэля Альвара, перешедший в Киев из Западной Европы еше в XVII в., а затем и в русские школы. В Р оссии он неоднократно переиздавался, несмотря на то что, по мнению историка П. Пекарского, «из всех учебников латинского языка грамматика Альвара была, может быть, самым темнейшим, так, что была непонятна не только для начинающих изучать латынь, но даже и для тех, кто знал ее порядочно» ${ }^{2}$. Неудивительно, что в низших классах хлыновской школы многие «малые», «тупые и непонятные» учились по шесть-восемь лет.

Поэзия, которая изучалась в хлыновской школе, была, по существу, киевской. Русской поэзии тогда фактически просто не было. Под стихами понимали умение слагать силлабические вирши (от лат. versus) на латинском и славяно-российском «диалектах». Некоторые, наиболее талантливые учителя «пиитики» составляли свои собственные учебники поэтики. М. Е. Финиџкий в 1741 г. усовершенствовал «пиитический» учебник Горки. Первую часть учебника занимают рассуждения о природе и џелях поэзии; во второй, третьей и четвертой характеризуются ее разнообраз-

${ }^{1}$ Поздеев В. А. Лаврентий Горка // Энциклопедия Земли Вятской: в 10 т. Т. 2. Литература. Киров, 1995. С. 29-30. С. 30.

2 Пекарский П. История науки и литературы в России при императоре Петре Великом: в 2 т. Т. 1. СПб., 1862. 420 с. С. 242. 
ные жанры. Изложение сопровождается примерами из Вергилия, Гораџия, Овидия, причем многие стихи даны в переводах Горки.

Учебники поэтики того времени обычно содержали два отдела. В первом отделе речь обычно шла о џели поэзии, смысле и содержании поэтического «измысла»; о том, как следует подражать великим поэтам, о средствах поэтического творчества, об особенностях силлабического стихосложения; все это тогда называлось по-латински subsidia poeseos. Второй отдел включал сведения о различных родах и видах поэтических произведений, о поэзии «эпической, комической, трагической, элегической, буколической, сатирической, лирической и эпиграмматической». Основную часть первого отдела учебника составляли сведения из мифологии, считавшейся тогда очень важной составной частью поэзии. Здесь приводились сведения о богах и богинях Олимпа, нимфах и наядах, мифологических героях (Ахиллес) и исторических личностях (Александр Македонский). Во втором отделе, помимо определений и теории, приводились выдержки из стихов Стефана Яворского, Фреофана Прокоповича, Антиоха Кантемира, а также самих составителей пособия. Давались также наставления по составлению стихов, особенно «гратуляџй̈» - поздравительных стихов и од в честь различных высокопоставленных персон. В учебниках поэтики приводились образџы «змеиных» (versus serpentiri) и «ретроградских» эпиграмм. Под последними понимаются стихотворные фразы, которые могут читаться слева направо и справа налево. Например, «Otto tenet madidam mappam madidam tenet Otto».

Венџом наук в Хлыновской славяно-латинской школе была риторика. И здесь учителя нередко занимались по ими же самими составленным пособиям. Известны учебники вятских учителей Андрея Свирепова (или иеромонаха Трифиллия) «Regulae Rethorics» («Правильная риторика») и М. Е. Фриниџкого «Regia Tullinae eloquentiae, Wiatcensi benevolae juventuto, per professorem Michaelem Finicky, procurantem feliciter construeta» («Чертоги Туллиевой элоквенџии, написанные для вятских школьников профессором Михаилом Финиџким»).

Пособия обычно включали «разсуждения» («трактаџии») о сущности и џели «реторики», о том, как следует «изобретать» мысль, об «орнаментах» риторической речи - тропах и фигурах. В разделе «de arta oratoria in particulari» излагались наставления по сочинению писем и речей поздравительных, приветственных, благодарственных, просительных, прощальных, надгробных и т. п. Здесь можно найти подробные рецепты относительно того, в каких выражениях ученик должен обращаться с родителями при выходе из дома и при возвращении домой, например, из школы; какими «тропами» и «фигурами» должен просить у старших денег, как поздравлять с Новым годом, днем рождения, христианским праздником и т. д. Здесь же даются советы о произношении и «красноречии священном», то есть краткие и сухие правила о том, 


\section{История отечественного образования и педагогики..........91}

как составлять и произносить «риторические предики», - проповеди.

Умение составлять предики очень џенил $\mathcal{~}$. Горка. Он был первым проповедником в Хлынове, который сам составлял устные проповеди. Даже самая простая проповедь считалась в то время слабой и «не изяшной», если в ней не было "мифологических применениї. Не всегда простым, неграмотным жителям Хлынова, приходившим в храмы, были понятны «предики» первых проповедников. Но это был первый опыт живой устной речи, свободного обращения к большой массе народа. Вслед за наставлениями в умении составления и «апробаџии» живой проповеди упражнялись и учашиеся. М. Е. Финиџкий отмечает: «В школах мною основанных, некоторые из студентов в толикую моими трудами произошли науку, что во всю покойного преосвященного Вениамина бытность поучения в церквах сказывали, також уже и в бытность вашего преосвященства, какового суть оныя учения, в самоперсональном проповедения их слушании ваше преосвяшенство аппробовать их изволил».

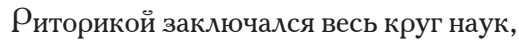
которым обучали в Хлыновской славяно-латинской школе. Правда, $\mathrm{Ð}_{\text {и- }}$ ниџкий в своей просьбе об увольнении от учительской должности отмечал, что он «латинского диалекта школы от самых Альваровых рудиментов (т. е. основ - В. П.) произвел своими трудами до риторики и диалектики». И хотя в учебнике М. Е. Фһницкого «Чертоги Туллиевой элоквенџии...» изложение «диалектики» отсутствует, можно предположить, что требования жизни побуждали его в рамках риторического класса изучать и вопросы, относяшиеся к предмету изучения в высших классах, то есть к диалектике и богословию, хотя офиџиально в школе они не изучались. Класс риторики был открыт в 1738 г. Некоторые школьники оставались в нем по несколько лет и, «выслушав», таким образом, полный курс школы, жаловались, что «за непроизведением в школе высших наук» (то есть ввиду отсутствия классов философии и богословия - В. П.) быть им в реторике вельми стало скучно, и в оной школе они всуе содержатся, и токмо лета теряют напрасно» ${ }^{2}$.

Не имея возможности открыть в школе высшие классы, епископ Варлаам летом 1742 г. разрешил желавшим получить высшее образование отправиться для продолжения учебы в столичные города. Так, будущий профессор медиџины Константин Џепин избрал Киевскую духовную академию; Мина Мышкин и Федор Порошин, взявший впоследствии фамилию Радикорский по названию родного села, «для слышания философии и богословия» отправились в Московскую славяно-греко-латинскую академию. Мышкин и Порошин

\footnotetext{
1 Два прошения М. Е. Финицкого преосвященному Варлааму Скамницкому. 1743 и 1745 гг. // Труды Вятской ученой архивной комиссии. Выпуск 3. Отдел 3. Вятка, 1905. С. 95-97. C.97.

${ }^{2}$ Верещагин А. С. История Вятской духовной семинарии // Вятские епархиальные ведомости. 1868. № 12. С. 197-204. С. 199.
} 
обучались в Москве более пяти лет, потом вернулись в Хлынов и были здесь в семинарии преподавателями - соответственно - поэтики и риторики. Учителя риторики и поэтики были главными учителями в школе; они руководили и школой, были «экзаминаторами» в низших классах. Еженедельно посещали они каждый класс и вели наблюдение за работой всех учителей.

Соратник и последователь $\curlywedge$. Горки М. Е. Ф иниџкий, фактически возглавивший школу после смерти епископа, проявил себя и как видный поэт своего времени. Художественный уровень его «гратуляџй̈» свидетельствует о несомненном таланте М. Е. ФИниџкого. Например, ᄉ. Горке он посвятил проникновенные строки: «По умершем Лаврентии предобром пастыре / Полно все слез в сем Вятском мире...».

...10 апреля 1737г. был праздник Святой Пасхи. По окончании обедни все власти города Хлынова поспешили в архиерейский дом принести поздравления преосвященному Владыке. Но у дверей дома они были остановлены двумя верными слугами епископа $\square$ калмыками Титом и Романом, обращенными в христианство в бытность служения Лаврентия в Астрахани и последовавшими за своим

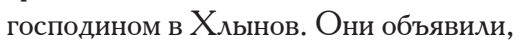
что «Владыка почивает» и не следует его беспокоить. Вечером того же дня, по окончании радостного пасхального звона во всех храмах города, печаль- ные звуки соборного колокола известили горожан о том, что их архипастырь «почил тем непробудным сном, от которого возбудит его только труба архангела (Михаила - В. П.)» ${ }^{1}$

Несколько человек, в их числе духовник Владыки архимандрит Лаврентий Полтораџкий, М. Е. Финиџкий и В. Лещинский, а также два келейника были свидетелями кончины $\mathcal{\Lambda}$. Горки, последовавшей в седьмом часу вечера. Первый вятский просветитель ᄉаврентий Горка был похоронен в Вятском кафедральном соборе, на северной стороне, в холодном храме. В надписи на гробниџе, устроенной в 1772 году, он назывался «ревностным по Бозе Иерархом, бодрым словесных овеџ пастырем, мудрости и благочестия любителем, крайним невежества и суеверия ненавистником». Здесь же спустя столетие были выбиты вдохновенные строки, дань памяти первому просветителю на Вятской земле:

«Всеобщй смертный рок в сём месте мужа скрыл,

Который первый здесь науки насадил, -

Хотя Всевышня Власть, что џелым светом правит,

Ему и не дала конечно

их возставить.

Лаврентий Горка сё!

А кто он был таков?

Епископ вятский, муз любитель, богослов».

Большинство хлыновского духовенства полагало, что школа - затея «поляка-архиерея» со смертью «за-

\footnotetext{
${ }^{1}$ Верещасин А. С. История Вятской духовной семинарии // Вятские епархиальные ведомости. 1868. № 2. С. 24-32. С. 31.
} 
История отечественного образования и педагогики..........93

тейшика» «покончится». И, действительно, первые два месяџа после смерти $\mathcal{\lambda}$. Горки были временем ее полной дезорганизаџии. Однако уже в середине июня 1737 г. был получен указ Святейшего синода с требованием «содержать школы как было при жизни преосвященного Лаврентия во всем неотменно» ${ }^{1}$. Славяно-латинская школа ᄉ. Горки, вскоре после его смерти пришедшая в упадок, сравнительно быстро была восстановлена и на многие десятилетия стала одним из виднейших џентров просвещения не только в Вятском крае, но и на территории всей Северо-Восточной России.

Подвижническая жизнь Горки стала предметом спеџиального изучения со стороны вятских историков, начиная со второй половины XIX в. Неоценимый вклад в изучение личности Горки и его просветительской деятельности в Вятском крае внес замечательный местный историк А. С. Верешагин, живший в XIX в. Во многом благодаря его трудам мы имеем сейчас возможность представить то, каким образом начинался проџесс просвешения на Вятке. Писатель Н. С. Лесков в своем сатирическом произведении «Святительские тени» дал описание деятельности вятских епископов XVIII века. Будучи в этом вопросе человеком совершенно беспристрастным, Н. С. Аесков уничтожающими эпитетами («бонвиваны», «бражники», «скопидомы», «невежи» и т. п.) охарактеризовал всех вятских «архипастырей», за исключением ᄉ. Горки, которого он признал достойным своего сана ${ }^{2}$.

В исключительно яркой и самобытной личности Лаврентия Горки с особенной силой привлекают его несгибаемая воля и настойчивость, огромная эрудиџия и значительный литературный талант, стремление даже џеной собственной жизни развеять вековую тьму невежества, помочь народу в преодолении извечного российского отставания в области просвещения. До настоящего времени для вятского учительства $\mathcal{\lambda}$. Горка выступает своего рода нравственным ориентиром. Его имя считается символом просветительства, беззаветного служения просвещению народа. $\mathrm{He}$ смотря на свое непродолжительное пребывание «на Вятке», $\mathcal{\lambda}$. Горка оставил по себе добрую, прошедшую сквозь века память.

\footnotetext{
${ }^{1}$ Помелов В. Б. Насилие гуманизма в деятельности первого вятского просветителя Лаврентия Горки // Традиции и новации в педагогике ненасилия: материалы всероссийской научной конференции / под ред. В. С. Данюшенкова и В. А. Ситарова. Киров, 1996. C. 79-81.

2 Лесков Н. С. Святительские тени // Исторический вестник. 1881, № 5. С. 53-69.
} 


\section{Список литературы}

1. Верешагин, А. С. История Вятской духовной семинарии / А. С. Верешагин // Вятские епархиальные ведомости. - 1868. - № 1. - С. 4-19.

2. Верешагин, А. С. История Вятской духовной семинарии / А. С. Верещагин // Вятские епархиальные ведомости. - 1868. - № 2. - С. 24-32.

3. Верешагин, А. С. История Вятской духовной семинарии / А. С. Верешагин // Вятские епархиальные ведомости. - 1868. - № 12. - C. 197-204.

4. Верещагин, А. С. Ученый южнорусс на Вятке в XVIII в. / А. С. Верешагин // Памятная книжка и календарь Вятской губернии на 1895 г. Отдел IV. - Вятка, 1894. - С. 302-321.

5. Верешагин, А. С. Эпизоды из жизни основателя Вятской семинарии. Эпизод V. Архиерейство на Вятке / А. С. Верешагин // Памятная книжка и календарь Вятской губернии на 1902 г. - Вятка, 1901. - С. 50-102.

6. Вятский архиерейский дом и архиерейские вотчины 1827 г. // Труды Вятской ученой архивной комиссии. Выпуски 1-2, отдел 3. - Вятка, 1916.

7. Два прошения М. Е. сриниџкого преосвященному Варлааму Скамниџкому. 1743 и 1745 гг. // Труды Вятской ученой архивной комиссии. Выпуск 3. Отдел 3. - Вятка, 1905. - С. 95-97.

8. Кудрявџев, И. М. Археографические экспедиџии отдела рукописей Госу- дарственной библиотеки имени В. И. Ленина в 1953-1956 гг. / И. М. Кудрявџев, Б. А. Шлихтер, Я. Н. Шапов. - М., 1956. - C. 256-301.

9. Лесков, Н. С. Святительские тени / Н. С. Лесков // Исторический вестник. - 1881. - № 5. - С. 53-69.

10. Ауппов, С. П. Книга в России в послепетровское врмя. 1725-1740 / С. П. Ауппов. - ᄉ., 1976. -420 с.

11. Никитников, Г. А. Иерархия Вятской епархии / Г. А. Никитников. - Вятка, 1863. - 214 с.

12. Пекарский, П. История науки и литературы в России при императоре Петре Великом: в 2 т. - Т. 1. / П. Пекарский. - СПб., 1862. - 420 с.

13. Поздеев, В. А. Лаврентий Горка / В. А. Поздеев / / Энџиклопедия Земли Вятской: в 10 т. Т. 2. Литература. - Киров, 1995. - С. 29-30.

14. Помелов, В. Б. Насилие гуманизма в деятельности первого вятского просветителя Лаврентия Горки / В. Б. Помелов // Традиџии и новаџии в педагогике ненасилия: материалы всероссийской научной конференџии / под ред. В. С. Данюшенкова и В. А. Ситарова. - Киров, 1996. - C. 79-81.

15. Преснецов, Р. М. «Который первый здесь науки насадил» / Р. М. Преснецов // Краеведческий сборник «Вятка» / / под ред. Е. Д. Петряева. - Киров, 1975. - С. 107-112. 
История отечественного образования и педагогики..........95

\author{
Г. А. Фуртова \\ Т ЕХНИЧЕСКИЕ СРЕДСТВА \\ ОБУЧЕНИЯ В ПРАКТИКЕ \\ РОССИЙСКОГО ОБРАЗОВАНИЯ \\ ХІХ - НАЧАЛА ХХ ВВ.
}

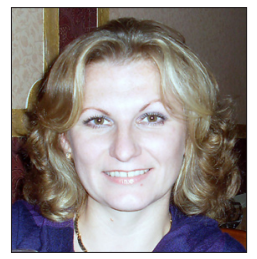

УДК 371.64/69

ББК 74.026 .84

В статье освешается проџесс становления и развития технических средств обучения (ТCO) в сфере образования XIX - начала XX вв. на всех ступенях обучения: при проведении народных чтений, деятельности народных домов и университетов, в начальной и средней школе. Раскрывается роль государственных и обшественных организаџий в распространении ТСО.

Ключевые слова: технические средства обучения; наглядное обучение; волшебный фонарь; методика преподавания; стереоскоп; народные чтения; народные дома; кинематограф; педагогический музей наглядных пособий.

G. FURTOVA

\title{
TECHNICAL TRAINING TOOLS IN PRACTICE OF RUSSIAN EDUCATION XIX - EARLY XX CENTURIES
}

The article highlights the process of formation and development of technical training aids in the education sphere of the XIX - beginning of XX centuries at all levels of education: elementary and middle school, holding of popular lectures, activities of people's houses and universities. The role of public organizations in the dissemination of technical training aids is defined.

Key words: technical training; visual training; magic lantern; teaching methods; stereoscope; popular readings; public house; cinema; pedagogical Museum of visual AIDS.

В современных условиях объем информаџии, получаемой человеком, с каждым годом увеличивается, и молодому поколению приходится учиться адаптироваться в ее потоке.
Медиапроектор, интерактивная доска, «говоряшая» азбука, лингафонные аппараты - это далеко не весь перечень технических средств, являющихся подспорьем в работе современного учите- 
ля. Все эти «приобретения» новейшего времени имеют интересную и богатую историю возникновения и развития, но проблема заключается не в использовании технических средств как таковых, а в эффективности достижения тех или иных образовательных результатов с их помощью. Применение любого, даже самого сложного средства обучения не может быть самоџелью образовательного проџесса. Это лишь «инструмент» развития познавательной активности ребенка, его творческих сил, учебных умений, личностных качеств, связанных с пониманием себя и окружающего мира. Важной является проблема педагогического и методического оснащения материальных носителей информаџии, «педагогизаџии» технических новинок и их эффективного использования в деле просвещения и образования.

В этой связи попробуем обратиться к первоосновам и определить, каким образом в России XIX века складывались взаимоотношения между передовой технической мыслью и педагогической наукой, как происходило становление и развитие методики применения инженерных изобретений в образовательной практике, что определяло использование тех или иных средств в практической деятельности учебных заведений разных типов и видов.

Сразу оговоримся, что «технические средства обучения» - понятие современной педагогики. Впервые мы встречаем его в энџиклопедических изданиях конџа 60-70-х гг. XX в. Так, например, в Большой советской энџиклопедии под техническими средствами обучения понимаются «системы, комплексы, устройства и аппаратура, применяемые для предъявления и обработки информајии в пројессе обучения с џелью повышения его эффективности» ${ }^{1}$. Несмотря на то что устойчивое понятие «технические средства обучения» появилось сравнительно недавно, сами подобные устройства начали применяться в педагогической практике достаточно давно.

В России первые проекџионные аппараты - «волшебные фонари» - появились в начале XVIII в. Тогда они, по словам физика Н. С. Хотинского, «были в большом ходу у магов и чародеев». Но уже в конџе XVIII века диапозитивы на стекле, проеџируемые на экран с помощью фонаря, применялись с учебной џелью - для описания путешествий и изучения анатомии. К середине XIX столетия века проекционный аппарат «вошел почти во всеобщее употребление не только в высших учебных заведениях, но даже в полковых учебных командах и народных школах - везде он оказывает большое пособие обучающимся» ${ }^{2}$. В 1858 г. в Петербурге в публичной аудитории читались об-

1 Технические средства обучения // Большая советская энциклопедия: [в 30 т.] / гл. ред. А. М. Прохоров. 3-е изд. М.: Советская энциклопедия, 1969-1978, Т. 26. С. 529.

2 Борисов Н. И. Волшебный фонарь в народной школе (По данным Александрийского уездного земства за 1889-1895 годы). Херсон: Изд-е Херсонской Губернской Земской Управы, 1896. $186 \mathrm{c}$. 
шедоступные лекџии в сопровождении демонстраџии «волшебного фонаря», а в 1877 г. была издана книга «Волшебный фонарь» как пособие для педагогов и лекторов, применявших технику.

По мнению преподавателей того времени, проекџионные аппараты являлись «одними из могушественных пособий для преподавания». Как писал Н. Животовский, «при их помоши не только џелая аудитория может следить с пользой за объяснениями лектора, но благодаря значительному увеличению мельчайшие подробности наблюдаемых явлений совершенно точно обрисовываются перед зрителями. Эти чудесные зрелища, помогающие узнавать причину вещей, запечатлеваются навсегда в уме и к ним можно вполне применить слова великих франџузских популяризаторов: «Видеть это почти то же, что знать» ${ }^{1}$.

K началу XX в. конкурентом волшебному фонарю в деле образования стал стереоскоп. При сохранении тех же џелей, что и у волшебного фонаря - сделать преподавание наглядным и занимательным - стереоскоп сделал возможным индивидуальный характер обучения: каждый ученик мог самостоятельно работать с данным техническим средством. Стереоскоп не требовал затемнения класса и спеџиального источника света; он был дешевле, картины для него произво- дились на бумаге (следовательно, они не бились), и он не требовал спеџиальных умениі при обрашении с ним.

В рассматриваемый период для иллюстраџии учебной информаџии в России применялись также фенакистископ, стробоскоп, зоотроп, кинеограф, праксиноскоп и другие аппараты, используюшие разные источники освешения и способы проекџии.

Новым техническим средством не только обучения, но и самообучения стали уникальные и простые в изготовлении приспособления - арифмоскоп и альфабета-арифмоскоп Т. Ф. Сваричовского, пособия для наглядного изучения нумераџии и десятичных чисел. В своей монографии автор данного ТСО писал: «В школах обыкновенно пользуются главным образом органами зрения и слуха; при отсутствии мускульных навыков (необходимых при развитии вообще), дающих возможность координаџии движения, получается вялость развития интеллекта, сонливость, инертность. Представление тогда будет полным, если в восприятии участвует возможно большее (в зависимости от надобности) число органов чувств» ${ }^{2}$. C помошью арифмоскопа оказалось возможным за один урок «научить детей читать и писать десятичные числа и познакомить с идеей увеличения и уменьшения значений десятичного числа от перенесения запятой; и

\footnotetext{
1 Животовский H. Волшебный фонарь, его описание и употребление// Педагогический сборник 1874. кн.VII. С. 703.

${ }^{2}$ Сваричовский Т. Ф. Арифмоскоп Т. Ф. Сваричовского. Прибор для наглядного изучения нумерации и десятичных чисел. М., 1913. С. 5.
} 
это при наличности 40 человек и при среднем составе класса».

Весной 1896 г. в России были показаны первые кинофильмы - сначала на Нижегородской ярмарке, затем в Петербурге и Петергофе, в Москве, Одессе и других городах. Достаточно быстро кинематограф стал использоваться в практике образования и просвещения, в том числе в «глубинке». Так, в Пирятинском уезде Полтавской губернии попечитель Свечковского земского училища г. Загружский пожертвовал 200 руб. на приобретение школьного кинематографа. Учитель училища г. Даниленко принял на себя труд по его выписке и приспособлению для конкретных нужд. Земство открыло кредит для выписки на прокат картин, одобренных инспектором народного училища. Таким образом, в глухом селе Свечковке, в 40 верстах от города появился кинематограф фирмы «Кок», в помещении земского училища начались киносеансы. «Учашиеся и взрослое население усердно посещали сеансы, сопровождающиеся объяснительным чтением. Плата за вход не взималась... Пирятинское земство предполагает ассигновать необходимую сумму на приобретение еще двух школьных кинематографов»1.

К началу XX века технические изобретения коснулись не только визуальных способов представления ин- формаџии, но также фиксаџии и затем воспроизведения звука. Примерно в 1907 г. был создан усовершенствованный граммофон - оксетофон, данное изобретение стали широко использовать в обучении: лекџии теперь могли сопровождаться не только демонстраџией диапозитивов, но и воспроизведением звука с грампластинок ${ }^{2}$.

С появлением и развитием технических средств обучения принџип наглядности обрел новое значение в педагогической теории и практике. «Самый метод наглядного обучения, пользующийся одновременно органами зрения, слуха, а иногда и мускульного оџушения, вполне соответствует духовной природе человека и обычному способу составления понятий», - писал об этом известный педагог того времени Н. В. Чехов. Открылись новые возможности для повышения әффективности образовательного проџесса ${ }^{3}$.

К началу XX века технические средства обучения применялись в России на всех этапах обучения и в рамках всех форм организаџии учебного проџесса, был совершен своеобразный «технический прорыв» в сфере образования.

Если в первой половине XIX века появление и распространение технических средств обучения было связано с отдельными частными ини-

1 Кинематограф в школе// Педагогический журнал. 1914. № 2. С. 49.

${ }^{2}$ Карпов Г. В. Технические средства обучения: Учеб. пособие для студентов пед. ин-тов 2-е изд., перераб. и доп. М.: Просвещение, 1972. С. 312.

3 Чехов Н. В. Наглядность обучения и наглядные пособия в начальной школе. М., 1904. C. 5 . 
История отечественного образования и педагогики..........99

џиативами, и этот опыт носил единичный характер, то реформы 1860-х гг. (особенно земско-административная) открыли дорогу обшественным силам (педагогическим объединениям, земским собраниям - уездным и губернским) в строительстве новой школы. Первыми шагами земств в области образования и просвешения была организаџия так называемых «подвижных школ», деятельность которых была направлена на распространение грамотности и научных представлений об окружающем мире среди различных слоев населения. Чтения и беседы в них, как правило, сопровождались показом картин с помошью имеюшихся проекџионных аппаратов того или другого вида. Так, согласно материалам «Сборника правительственных распоряжений по делам, до земских учреждений относящимся» (1890г.), земским врачам было разрешено проводить в народных училишах беседы «с џелью ознакомления учеников и крестьян с элементарными понятиями по анатомии, физиологии и гигиене». Программа бесед вырабатывалась совместно с земской управой, занятия сопровождались показом картин с помощью «волшебного фонаря» .

Во многом ТСО стали передовым «локомотивом» в распространении знаний. По мнению В. П. Вахтерова, одним из самых главных и чуть ли не «единственным проводником в среду наиболее темного неграмотного населения» являлась наглядность, демонстрируемая с помощью технических средств обучения. «Народные чтения» являлись одним из распространенных способов проникновения внешкольного образования в массы; благодаря им распространялись общеобразовательные и профессиональные или прикладные знания, слушателям доставлялись «разные формы әстетического наслаждения», решались задачи религиозно-нравственного воспитания.

По Высочайшему повелению от 16 апреля 1872 года устройство народных чтений в Санкт-Петербурге и его окрестностях было предоставлено особой Постоянной Комиссии, которая обязана была «озаботиться распространением их в народе» ${ }^{2}$. В 80 -х гг. были разрешены чтения религиозного содержания в уездных городах и селах, проводиться они должны были священниками «при их должном обучении работе с туманными картинами» ${ }^{3}$.

Оџенивая значение использования «волшебных фонарей» и туман ных картин при проведении народных чтений в России, Г. А. Жуков в своей работе «Учебный проекџионный фонарь. Великий пособник учению в средней школе» писал: «При иллюс-

1 Пругавин A. C. Законы и справочные сведения по начальному народному образованию. СПб.: Изд-во Товарищества «Общественная польза», С. 687.

2 Там же. С. 694.

${ }^{3}$ Медынский E. H. История русской педагогики до Великой Октябрьской Социалистической революции: учебник для пед. вузов. 2-е изд., испр. и доп. М.: Учпедгиз, 1938. C. 384 . 
трировании народных чтений, при демонстрађии в глазах массы многих исторических, географических и вообще научных явлений оказалось возможным пользоваться получаемым при помоши проекџионного фонаря его световым эффектом в такой степени, как никаким другим наглядным средством раньше этого не достигалось...»».

С каждым годом использование ТСО при публичных лекџиях и народных чтениях принимало все большие масштабы. Так, в Московском уезде они устраивались при всех 72 земских школах и ежегодно, начиная с 1887 г., велись в 75-95\% от общего числа школ. «В среднем на каждую школу приходится от 3 до 5-6 чтений в течение учебного года. Число слушателей колебалось от 40 до 58 тысяч ежегодно; в 1895-1896 уч. году было 17695 мужчин, 15357 женшин и 24742 детей. В своем распоряжении земство имеет 46 фонарей (21 училище - каждое отдельный фонарь и 51 - по одному на 2 школы и 1535 картин, в том числе 590 духовного содержания, по истории и биографии - 439, из произведений русских писателей - 258, географических - 130, по мироведению - 67 и 51 этнографических)» ${ }^{2}$. Порядок и регламент открытия народных чтений неоднократно менялся (Положение Комитета Министров от 28 янва- ря 1901 г.; доклад министра народного просвешения гофмейстера гр. Толстого от 4 февраля 1906 г.; решение заседания Совета Министров от 9 января 1907 г. и др.), наконеџ, в 1907 году был одобрен явочный порядок устройства народных чтенй, что позволило проводить их с учетом аудитории, правильно подбирать необходимый «волшебный фонарь» и световые картины.

При проведении чтений большая часть расходов приходилась как раз на покупку «волшебных фонарей» и картин. В этот период в России уже было открыто достаточно много оптических магазинов и мастерских, которые изготовляли и продавали «волшебные фонари» и принадлежности к ним: О. Рихтер - оптик и механик; С.Петербургская мастерская учебных пособий; Ф. Швабе - физико-механик и оптик в Москве; Московская мастерская картин для волшебных фонарей А. Ф. Анџыферовой в Москве; Художественная мастерская световых картин А. В. Заикина в Москве; Алферова в Харькове и др.

Часто, не имея возможности приобрести и использовать различные ТСО в каждой школе, земства принимали решения о переходе обучаюших технических средств от одного учебного заведения к другому внутри уезда или района. Для систематического контроля за количественным и

\footnotetext{
${ }^{1}$ Жуков Г. А. Учебный проекционный фонарь, великий пособник учению в средней школе. СПб.: тип. М. М. Стасюлевича, 1902. С. 3.

2 Пругавин А. С. Законы и справочные сведения по начальному народному образованию. СПб.: Изд-во Товарищества «Общественная польза», 1904. С. 688.
} 
История отечественного образования и педагогики...... 101

качественным показателями использования ТСО составлялись каталоги и списки наглядных пособий ${ }^{1}$. В џелях пополнения знаний учителей и учительниџ о технических средствах обучения устраивались педагогические курсы, открывались так называемые «образцовые» школы.

Яркой страницей, иллюстрирующей активную деятельность общественных организаџий и объединений по внедрению ТСО в учебный проџесс российских школ, являлось создание, развитие, функџионирование таких необычных учреждений, как музеи и библиотеки наглядных пособий. Это были своеобразные «депо» технических средств обучения и их содержательно-методического обеспечения. Музеи покупали, хранили, каталогизировали и выдавали во временное пользование различные средства обучения тем учебным заведениям, которые в силу недостаточного финансирования не имели возможности приобрести их самостоятельно. Один из первых подобных музеев в нашей стране был открыт в 1864 году при Главном управлении военно-учебных заведений. Председателем комиссии по его работе стал генерал-лейтенант В. П. Коховский (1835-1891). Первоначально в Музее было собрано следующее имушество: «в витринах находились пособия для занятий по системе Ф. Фребеля; несколько картин заграничного производства по естественной истории, технологии и два ящика картин на стекле английского производства с волшебным фонарем» ${ }^{2}$. Постепенно Музей пополнялся приборами и ценными коллекџиями, а затем стал участвовать в выставках производителей учебных пособий, представляя полную, систематически подобранную картину всех пособиї, применяемых при воспитании и обучении: от азбуки до полного курса среднеучебного заведения. Благодаря неутомимому труду работников Педагогического музея военно-учебных заведений была собрана «богатейшая и единственная в мире коллекџия прозрачных картин на стекле, большой сборник оригиналов, составлены многие приборы и разные приспособления для наглядной передачи информаџии» для 200 тем народных чтений по всем отраслям знаний - священной истории, географии, мироведению, литературе и др. Для описания и систематизаџии собранной коллекџии был составлен «Каталог учебных и воспитательных пособий педагогического отдела Военного Министерства»³.

Вслед за первым музеем в нашей стране начали открываться аналогичные. Широкой известностью пользовался Санкт-Петербургский Подвижной музей наглядных пособий при постоянной Комиссии по

\footnotetext{
${ }^{1}$ Вахтеров В. П. Новая школа // Народный учитель. 1906. № 13. С. 33

2 Рогов П. Памяти В. П. Коховского // Русская школа. 1891. № 12. С. 49.

${ }^{3}$ Воронечкий А. В. П. Коховский в роли организатора народных чтений в Соляном городке // Русская школа. 1892. № 2. С. 37.
} 
техническому образованию Русского технического общества, основанный кружком частных лиџ в 1892 г. $^{1}$

В практике народного просвешения ТСО выполняли главным образом иллюстративную функџию: информаџия, представленная с их помоџью, точно соответствовала содержанию проводимых чтений, лекџий, бесед, а ведущим методом работы было «разъяснение на словах» картин или опытов, «не выходя из пределов текста» спеџиально подготовленных и утвержденных брошюр «без всяких дополнений и изменений».

В проџессе обновления начального и среднего образования во второй половине XIX века российские педагоги стали стремиться к такому построению урока, которое бы стимулировало активную и самостоятельную познавательную деятельность учащихся, формировало у них потребность в знаниях. Многие видели этот путь в использовании наглядности. Осмысление и оформление теории ТСО происходило «на стыке» встречных проџессов: разработки обших вопросов дидактики (динамика џелей и џенностей образования, борьба формального и реального подходов к его содержанию, проблема метода обучения, обоснование новых организаџионных форм и др.) и рефлексии и обобшения опыта использования ТСО учителями-практиками.

Создание методики использования ТСО в учебном проџессе во многом опиралась на обшедидактические принџипы наглядного обучения, разработанные К. Д. Ушинским, И. И. Паульсоном, В. И. Водовозовым, В. П. Вахтеровым, Д. И. Тихомировым и др. Учителяпрактики конструировали и реализовывали конкретные методические приемы по работе с техническими средствами обучения.

Вопрос реконструкџии и понимания особенностей реальной практики организајии и проведения учебных занятий с помощью ТСО достаточно сложен неоднозначен. Как правило, мы обладаем источниками в виде методических пособий и записок, нормативных документов (программ, џиркуляров, офиџиальных писем и т. д.), а также отчасти сведениями, почерпнутыми из мемуарной и эпистолярной литературы. На основе анализа данных расскажем об особенностях применения ТСО при обучении грамоте, родному языку и словесности; арифметике, основам соџиальных и естественных наук.

Авторами новых методических приемов, а иногда и авторами новых технических приспособлений становились в то время многие педагоги, в том числе провинџиальные. Так, учитель-практик из Минусинска Катанов создал техническое средство обучения для изучения русского языка - букварь-ящик. «В ящике два вала, на которые наматываются целые ленты с буквами, словами и предложениями.

Страхова М. И. Подвижной музей наглядных учебных пособий в Петербурге: Очерк. СПб.: тип. И. Н. Скороходова, 1902. [2]. 16 с. 


\section{История отечественного образования и педагогики...... 103}

Против этих валов спереди есть отверстия, которые могут быть задвинуты полностью или отчасти, отдельными дошечками. У каждого вала есть ручка, поворот которой выдвигает перед учениками новое слово или новую фразу. Учитель может постепенно регулировать быстроту чтения, удаляя читаемое слово скорее и скорее с глаз учеников» ${ }^{1}$. Данное ТСО включало в себя несколько тысяч слов и подходило к любому букварю (Вахтерова, Тихомирова и др.). Методика обучения грамоте с применением букваря-ящика также использовалась учителями для установления связи между классным и домашним чтением, что, по мнению А. П. Пинкевича, способствовало привитию интереса к чтению более серьезных книг. Той же џели служило классное чтение с картинами, демонстрируемыми при помоши волшебного фонаря ${ }^{2}$.

Во второй половине XIX века педагоги стали широко обрашаться к практическим методам обучения, тем самым делая следуюший шаг в использовании ТСО - от пассивной созерџательности к активным действиям учашихся. Достаточно плодотворно работал в этой области, например, В. П. Вахтеров. Как теоретик и методист начального обучения, как учи- тель-практик, он детально разработал и теоретически обосновал методику проведения практических занятий в начальной школе.

Он полагал, что большое значение в ходе таких занятий имеет демонстраџия предметов и проџессов с применением технических средств обучения. Важным условием эффективной работы на практических занятиях он считал четкость, яркость представляемых картин, без которых «нельзя обойтись в курсе анатомии и физиологии человека, при изучении некоторых животных и растений и пр.». По его мнению, проведение опытов обязательно должно производиться самим учителем и учениками с помощью волшебного фонаря, стереоскопа и других технических средств обучения ${ }^{3}$. В. П. Вахтеров считал, что волшебный фонарь является самым лучшим пособием в преподавании основ географии: чтение всегда должно сопровождаться опытами, демонстраџиями картин, пособий и пр. ${ }^{4}$ Такие же методы могли быть использованы учителями при сообшении элементарных сведений по физике и химии. ${ }^{5}$

В. П. Вахтеров полагал, что использование наглядных и технических средств обучения должно присутствовать на любом учебном занятии.

1 Пинкевич А. П. Методика начального курса естествоведения (природоведения). 4-е изд., пересм. М.: Госиздат, 1922. С. 31.

${ }^{2}$ Там же. C. 49.

${ }^{3}$ Райков Б. Е. Организация практических занятий по неживой природе. Книга для преподавателя. 3-е изд. Птг.: книгоизд-во «Сеятель», 1922. С. 165.

${ }^{4}$ Вахтеров В. П. Внешкольное образование народа. Сельские склады. Книжные склады. Воскресные школы и повторительные классы. М.: Изд-во т-ва Сытина, 1896. С. 327.

${ }^{5}$ Там же. С. 327. 
Василий Порфирьевич предлагал следуюшую структуру урока, которую считал әффективной и сообразной природе ребенка:

- первый этап - предварительная (наглядная) беседа - непосредственное сообщение реальных знаний о предмете;

- второй этап - проведение опытов и наблюдений, «чтобы эвристический метод преподавания был проведен возможно полнее, чтобы ученики действительно сами наблюдали и сами делали выводы из своих наблюдений»;

- третий - расспросы учителем о том, что узнали ученики;

- четвертый этап - чтение статей в классной книге для чтения для создания более связанной формулировки того, что было на уроке ${ }^{1}$.

Вахтеров выделял следующие правила применения наглядности: ясность, хорошая видимость (величина картины), выразительность (красочность) изображения, движение, правильное (соответствуюшее теме) чередование картин. При проведении нескольких опытов или рассмотрения нескольких картин в течение одного урока В. П. Вахтеров обращал внимание на то, что «можно легко поддержать внимание детей, обновляя впечатление все новыми и новыми опытами, картинами» ${ }^{2}$. Ключевыми пунктами в методике наглядного обучения с помощью ТСО
В. П. Вахтеров считал два: «Сначала вопрос или задача, какую дети должны разрешить во время урока, а потом демонстраџия наглядного пособия или опыта, на основании которого должна быть разрешена поставленная задача» ${ }^{3}$.

К началу XX века практические занятия с применением технических средств обучения прочно вошли в систему преподавания различных предметов. Прежде всего, остановимся на преподавании естественных наук: физики, химии, биологии, географии. На уроках этих предметов технические средства применялись как традиџионно для обеспечения наглядности иллюстративного типа, так и в составе новых «активных» форм и методов обучения. Однако подчеркнем, что к концу XIX века, даже выполняя сугубо иллюстративную функџию, технические средства обеспечивали уже не только «статическую» наглядность, но и помогали учащимся составить представление о сложных динамических природных проџессах.

Большой вклад в разработку методики использования ТСО в преподавании естественнонаучных дисџиплин внес преподаватель коммерческого училища, известный методист естествознания, автор работ «Организаџия практических занятий по неживой природе» и «Методика практических занятий по природоведению» Борис

\footnotetext{
${ }^{1}$ Вахтеров В. П. Предметный метод обучения. 5-е изд., доп. и испр. М.: Тип. Т-ва И. Д. Сытина, 1918. С. 152.

2 Там же. С. 159.

${ }^{3}$ Там же, С. 160
} 


\section{История отечественного образования и педагогики...... 105}

Евгеньевич Райков (1880-1966). Он утверждал, что «введение в школьное естествознание предметности или предметного метода и педагогическое требование активности приводит к установлению «лабораторного метода» такого способа преподавания, где сами ученики производят опыты; а стремление воспитать самостоятельную мысль - к методу «эвристическому» 1 .

Обосновывая применение лабораторного метода, Б. Е. Райков отмечал: «При лабораторном методе изучение природы происходит не со слов учителя, хотя бы сопровождаюшихся демонстраџиями, а при помоџи самостоятельных занятий самих учеников, причем эти занятия кладутся в основу курса. Изучение явлений происходит на опыте, производимом до известной степени независимо от преподавателя, за которым остается лишь обшее руководство работами» ${ }^{2}$. Райков выделил преимушества использования технических средств обучения в рамках лабораторного или естественнонаучного метода по сравнению с традиџионной демонстраџией:

1. Более глубокое и прочное усвоение материала. «При обычном порядке приходится по очереди подводить учеников к микроскопу и очень быстро прекрашать наблюдение отдельного ученика, так как времени может не хватить, если каждый будет рассматривать достаточно долго. Если же ведутся практические занятия, то ученики сами устраивают опыт и, разбившись на группы, рассматривают, зарисовывают, обмениваются впечатлениями по поводу наблюдаемого». Поэтому результаты первого наблюдения можно назвать отрывочными и плохо воспроизводимыми учениками, а второго - прочными и, как правило, представляюшимися для учеников полной отчетливой картиной.

2. Соответствие возрасту и психическому развитию учащихся, что обусловливает их деятельный интерес.

3. Объединение деятельности психической и физической, координајия умственной деятельности учеников с деятельностью органов движения. «Эта сторона формального значения самостоятельных занятий особенно важна, - писал Б. Е. Райков. - Школа должна готовить ученика к жизни, должна приучить его не только размышлять, но и действовать, одно же пассивное восприятие в классе не может научить этому. Самостоятельные занятия ведут к тому, что мысль, слово и дело соединяются вместе. Ученик не только думает, говорит, но и делает».

4. Совершенствование органов чувств и приучение к точным и рассчитанным движениям.

5. Сближение учителя с учеником с џелью индивидуализаџии применения педагогических приемов.

6. Практические занятия как собственная, ненавязанная творческая де-

${ }^{1}$ Райков Б. Е. Организация практических занятий по неживой природе. Книга для преподавателя. 3-е изд. Птг.: книгоизд-во «Сеятель», 1922. С. 68.

${ }^{2}$ Там же. С. 70. 
ятельность ученика. «Ученик, по возможности, самостоятельно приходит к открытию все новых и новых истин, а это открытие вызывает в нем радость - радость творчества».

7. Нравственное значение практических занятий: «Работая вместе с другими, ученик все время должен считаться с тем, что он не один».

По мысли Райкова, новая техника проведения лабораторных уроков заключалась в идее «перенесения работы со стола учителя-экспериментатора на столики учеников...»1.

Методисты-физики, как правило, применяли ТСО на практических занятиях двумя способами: по системе «разных работ» и по системе работ «на один фронт».

Первая система - «разных работ», как правило, использовалась для закрепления изученного материала или в џелом пройденного курса, она предполагала наличие в физической лаборатории большого количест ва разнообразных приборов и ТСО (стереоскопы, микроскопы и пр.). Ученики при этом делились на группы по два-три человека и, чередуясь, в течение длительного времени (обычно это занимало порядка двух-трех месяцев) проходили весь курс работ.

Вторая система - система работ «на один фронт», в ее основе лежал принџип выполнения одинаковых работ на одних и тех же приборах. Такой подход мог применяться в течение всего учебного года и, как правило, использовался при изучении нового материала по ходу урока. Роль учителя при такой постановке дела сводилась лишь к координајии действий учеников при постановке проблемы и «остановке на существенных сторонах предлагаемой ученикам задачи» ${ }^{2}$.

Использовался также еще и «промежуточный тип», так называемая «смешанная система», которая предполагала проведение не одной работы, а нескольких несложных, например, двух-трех одновременно. В связи со сложностью методики проведения и значительным затягиванием времени система «разных работ» была более предпочтительна и нашла свое признание среди педагогов старшей школы, а на начальных этапах изучения физики наиболее подходящей оказалась система работ «на один фронт».

Обучаясь по любой из этих систем, ученики, тем не менее, «пользуясь указаниями преподавателя на те манипуляџии, которые надо произвести», сами или после разбора результатов совместно с преподавателем приходили к определенным выводам и «открывали» для себя законы природы ${ }^{3}$.

Таким образом, можно говорить о том, что в теоретических трудах и

\footnotetext{
${ }^{1}$ Райков Б. Е. Организация практических занятий по неживой природе. Книга для преподавателя. 3-е изд. Птг.: книгоизд-во «Сеятель», 1922. С. 71-80.

${ }^{2}$ Материалы по реформе средней школы. Примерные программы и объяснительные записки, изданные по распоряжению г. Министра Народного Просвещения. Птг:: Сенатская типография, 1915. С. 222.

${ }^{3}$ Там же. С. 223.
} 


\section{История отечественного образования и педагогики...... 107}

образовательной практике российских методистов использование ТСО в предметном обучении естественнонаучным дисџиплинам обрело тесные взаимосвязи с методами активизаџии самостоятельной познавательной деятельности учеников.

Та же тенденџия может быть прослежена в практике применения ТСО на учебных занятиях гуманитарного џикла.

Так, в своей работе «Кабинет русского языка» Н. М. Соколов и Г. Г. Тумин отмечали, что к началу $\mathrm{XX}$ в. методика обучения активно перерабатывается «под знаменем наглядности преподавания и развития самодеятельности учашихся», догматический метод сменяется әвристическим, «преподавание все более приобретает характер практических работ учащихся в присутствии и под руководством учителя» ${ }^{1}$. Авторы уделили особое внимание вопросам развития у детей литературного вкуса, әстетического воспитания и пр., считая, что достичь таких результатов можно только при условии, если в кабинете русского языка «дети будут смотреть туманные картины, иллюстрирующие литературные и иные темы, разбираемые на уроках родного языка» ${ }^{2}$.
В книге «Материалы по реформе средней школы» 1915 года издания мы обнаружили сведения о том, что во второй половине XIX века - начале $\mathrm{XX}$ в. при преподавании учебных предметов гуманитарного џикла в средних учебных заведениях применя лись волшебный фонарь, граммофон, фонограф, кинематограф, в рамках преподавания изобразительного искусства - проекџионные аппараты. Так, в гимназии № 8 им. А. К. и И. ᄉ. Медведниковых в Москве широко применялись диапроекторы (волшебные фонари) на уроках рисования (использовались слайды с произведениями известных художников), истории, литературы и других, причем это учебное заведение имело волшебные фонари и слайды к ним в собственном распоряжении ${ }^{3}$.

Технические средства обучения широко применялись и в преподавании иностранных языков. Так, Г. А. Жуков считал, что ТСО можно применять на любом этапе урока иност ранного языка «как подсказку смысла иностранной фразы с целью более легкого запоминания услышанного» ${ }^{4}$.

$\mathrm{B}$ начале $\mathrm{XX}$ в. на смену уже освоенным педагогикой техническим средствам обучения пришли новые.

\footnotetext{
${ }^{1}$ Соколов Н. М. Кабинет русского языка. Систематический указатель книг и пособий по преподаванию русского языка на первой и второй ступени обучения. Для учащихся и деятелей по народному образованию. 2-е изд., испр. и доп. Птг.: Жизнь и знание, 1917. С. 88.

${ }^{2}$ Там же. С. 22.

${ }^{3}$ Материалы по реформе средней школы. Примерные программы и объяснительные записки, изданные по распоряжению г. Министра Народного Просвещения. Птг.: Сенатская типография, 1915. $279 \mathrm{c.}$

${ }^{4}$ Жуков Г. А. Учебный проекционный фонарь, великий пособник учению в средней школе. СПб.: тип. М. М. Стасюлевича, 1902. С. 13.
} 
Важнейшим методическим новшеством, конечно, стал кинематограф. Как писал в то время историк-методист В. Уланов: «Нечего доказывать, какое громадное образовательное средство представляет в настояшее время кинематограф. Его роль с улучшением техники все более растет; головокружительные завоевания, сделанные кинематографом, как восходяшим светилом, склоняются самые скептические умы... Џенность научного кинематографа в том, что он передает самую жизнь, а не игру в жизнь» ${ }^{1}$. «Живая фотография всюду может и будет служить одним из наиболее совершенных учебных пособий», - отмечал В. А. Готвальд ${ }^{2}$. В. Лоскутов писал о том, что «картина сама по себе, кроме чисто образовательного значения, имеет глубокую психологическую основу, ничто так не действует на детскую душу, как наглядность и непосредственность, имеющаяся у кинематографа налиџо ${ }^{3}$.

Эффективность применения кинематографа при преподавании естественных и точных наук в средней школе обосновывал П. Барт: «В некоторых случаях, - писал он, - кинематограф, как учебно-воспитательное средство, прямо незаменим и то, что при пользовании им можно объяснить учащимся легко, без этого может быть объяснено гораздо хуже и лишь с затратой большого времени. ...В области геометрических конџепџий: учашимся объясняется образование геометрических тел, как результат перемещения в разных направлениях той или иной геометрической линии (прямой или кривой). Насколько трудно дать ученикам ясное, наглядное представление об этом без помощи кинематографа, настолько же легко и хорошо это достигается при пользовании живой фотографии; в области механики при объяснении учашимся законов движения, скорости и ускорений устраняются при раџиональном пользовании кинематографом; в области физиологии он помогает прекрасно изучить движение различных живых сушеств... с помощью изучения кинематографических снимков достигается ясное и отчетливое представление о движении различных частей аппарата, участвуюшего в фонаџии и артикуляџии» ${ }^{4}$.

K началу XX века кинематограф активно и повсеместно вошел в учебно-воспитательный проџесс средних учебных заведений Москвы и Петербурга. «Учебные кинематографы» имелись в первую очередь в привилегированных гимназиях, реальных училищах, кадетских корпусах (по некоторым данным их насчитывалось

\footnotetext{
${ }^{1}$ Катаев И. М. Вопросы преподавания обществоведения: (методические очерки). М.: Работник просвещения, 1926. С. 156-158.

${ }^{2}$ Готвальд В. А. Кинематограф: («живая фотография»): его происхождение, устройство, современное и будущее общественное и научное значение. М., 1909. С. 107.

3 Лоскутов В. Кинематограф и школа // Для народного учителя. 1913. № 10. С. 11-14; № 11. C. 15.

4 В. Б. Обзор журналов. Школьное кинематографческое обозрение. 1914. № 2. С. 56-57.
} 


\section{История отечественного образования и педагогики...... 109}

до нескольких сотен). В отдельных случаях киноустановки некоторых гимназий или реальных училищ обслуживали не только свое учебное заведение, но и другие. Так, например, частное реальное училище Черняева в Петербурге устраивало учебные киносеансы не только для своих реалистов, но и для учеников других петербургских реальных училищ и гимназий1.

Примером эффективного применения учебного кинематографа являлась учебно-воспитательная деятельность Тенишевского училиша, которое при постановке учебной части применяло кинематограф на уроках географии, естествоведения и истории. Кроме того, оно, объединившись с Петербургским обществом народных университетов, устраивало в своем помещении учебные киносеансы - лекџии для учашихся других учебных заведений и местной молодежи, занимающейся самообразованием ${ }^{2}$. Довольно широко кинематограф применялся и в петербургских кадетских корпусах при непосредственном участии Педагогического музея военноучебных заведений.

Широкое внедрение в учебный проџесс технических средств повлекло за собой решение многих взаимосвязанных дидактических, технических, психологических и организајионных задач. Технические средства в учеб- ном проџессе способствовали созданию новых организаџионных форм обучения. Они изменили методы и приемы проведения занятий, привели учебный проџесс в иное качественное состояние. Технические средства затронули и подходы к деятельности самого педагога в соотношении между его прямым и опосредованным воздействием на аудиторию.

Применение технических средств усовершенствовало учебный процесс, способствовало решению ряда образовательных задач. В свою очередь, новые возможности и потребности учебного проџесса стимулировали создание новых технических пособий. ТСО дополняли творческую деятельность учителя и расширяли возможности обучения: планируя урок, педагог мог самостоятельно определять, с какой целью и как использовать технические средства обучения на занятии, для решения каких образовательных или воспитательных задач он обрашался к тому или иному виду технических средств обучения, какой педагогический результат он планировал получить. Применение ТСО предусматривало методику проведения занятиї, основанную на проблемных, эвристических, игровых и других активных формах обучения, развивающих индивидуальность ребенка, самостоятельность его мышления,

\footnotetext{
${ }^{1}$ Роль российской общественности и технической интеллигенции в развитии просветительного кинематографа// Методичкус http://3ys.ru/rossijskij-dorevolyutsionnyj-kinematograf-stranitsy-istorii/rol-rossijskoj-obshchestvennosti-i-tekhnicheskoj-intelligentsii-v-razvitiiprosvetitelskogo-kinematografa.html. - Дата обращения 08.04.2016.

${ }^{2}$ Там же.
} 
стимулировавших его творческие способности через непосредственное вовлечение в творческую деятельность: организаџию и проведение лабораторных уроков, уроков «разных работ»и уроков «на один фронт», восприятие, интерпретаџию и анализ структуры текста, усвоения получаемых знаний. При этом ТСО, сочетая в себе свойства и потенџиалы как фронтальной, так и индивидуальной работы, явились своеобразным средством включения учашихся в проџесс создания интегрированного образовательного пространства, погружения аудитории в некую «внутреннюю лабораторию» содержания учебного предмета. Они способствовали выработке новой парадигмы преподавания: от «ученикасозерџателя» к «ученику-творџу».

\section{Список литературы}

1. Борисов, Н. И. Волшебный фонарь в народной школе (По данным Александрийского уездного земства за 1889-1895 годы) / Н. И. Борисов. - Херсон: Изд-е Херсонской Губернской Земской Управы, 1896. - 186 с.

2. В. Б. Обзор журналов. Школьный кинематограф / В. Б. // Педагогическое обозрение. - 1914. - № 2. - С. 51-58.

3. Вахтеров, В. П. Внешкольное образование народа. Сельские склады. Книжные склады. Воскресные школы и повторительные классы / В. П. Вахтеров. - М. : Изд-во т-ва Сытина, 1896. $380 \mathrm{c}$.

4. Вахтеров, В. П. Новая школа / В. П. Вахтеров // Народный учитель. - 1906. - № 13. - C. 3-6.

5. Вахтеров, В. П. Предметный метод обучения / В. П. Вахтеров. - 5-е изд., доп. и испр. - М. : Тип. Т-ва И. Д. Сытина, 1918. - 387 с.

6. Воронеџкий, А. В. П. Коховский в роли организатора народных чтений в Соляном городке / А. Воронеџкий // Русская школа. - 1892. - № 2. - С. 30-38.

7. Готвальд, В. А. Кинематограф: («живая фотография»): его происхождение, устройство, современное и будушее общественное и научное значение / В. А.
Готвальд. - М., 1909. - 120 с.

8. Животовский Н., Волшебный фонарь, его описание и употребление // Педагогический сборник - 1874. - кн.VII. - С. 703-704.

9. Жуков, Г. А. Учебный проекџионный фонарь, великий пособник учению в средней школе / Г. А. Жуков. - СПб. : тип. М. М. Стасюлевича, 1902. - 34 с.

10. Карпов, Г. В. Технические средства обучения: учеб. пособие для студентов пед. ин-тов / Г. В. Карпов, В. А. Романин. - 2-е изд., перераб. и доп. - М. : Просвещение, 1972. - 383 с.

11. Катаев, И. М. Вопросы преподавания обществоведения: (методические очерки) / И. М. Катаев. - М. : Работник просвещения, 1926. - 207 с.

12. Кинематограф в школе // Педагогический журнал. - 1914. - № 2. - C. 48-49.

13. Лоскутов, В. Кинематограф и школа / В. Лоскутов // Для народного учителя. -1913 . - № 10. - С. 11-14; № 11. - C. 14-18.

14. Материалы по реформе средней школы. Примерные программы и объяснительные записки, изданные по распоряжению г. Министра Народного Просвещения. - Птг. : Сенатская типография, 1915. - 279 с. 


\section{История отечественного образования и педагогики...... 111}

15. Медынский, Е. Н. История русской педагогики до Великой Октябрьской соџиалистической революџии: учебник для пед. вузов / Е. Н. Медынский. - 2-е изд., испр. и доп. - М. : Учпедгиз, 1938. $-512 \mathrm{c}$.

16. Пинкевич, А. П. Методика начального курса естествоведения (природоведения) / А. П. Пинкевич. - 4-е изд., пересм. - М. : Госиздат, 1922. - 327 с.

17. Пругавин, А. С. Законы и справочные сведения по начальному народному образованию / А. С. Пругавин. - СПб. : Изд-во Товарищества «Общественная польза», 1904. - 1096 с.

18. Райков, Б. Е. Организаџия практических занятий по неживой природе. Книга для преподавателя / Б. Е. Райков. -3 -е изд. - Птг. : книгоизд-во «Сеятель», 1922. - $116 \mathrm{c.}$

19. Рогов, П. Памяти В. П. Коховского // Русская школа. - 1891. - № 12. - C. 49.

20. Роль российской общественности и технической интеллигенџии в развитии просветительного кинематографа// Методичкус Режим доступа: http://3ys. $\mathrm{ru} /$ rossijskij-dorevolyutsionnyj-kinematograf-stranitsy-istorii/rol-rossijskoj-obshchestvennosti-i-tekhnicheskoj-intelligentsii-v-razvitii-prosvetitelskogo-kinematografa. html. Дата обрашения 08.04.2016.
21. Сваричовский, Т. Ф. Арифмоскоп Т. ФD. Сваричовского. Прибор для наглядного изучения нумераџии и десятичных чисел / Т. Ф. Сваричовский. - М., 1913. - 14 c.

22. Соколов, Н. М. Кабинет русского языка. Систематический указатель книг и пособий по преподаванию русского языка на первой и второй ступени обучения. Для учашихся и деятелей по народному образованию / Н. М. Соколов, Г. Г. Тумин. - 2-е изд., испр. и доп. - Птг. : Жизнь и знание, 1917. -220 c.

23. Страхова, М. И. Подвижной музей наглядных учебных пособий в Петербурге: Очерк. / М. И. Страхова. - СПб. : тип. И. Н. Скороходова, 1902. $-[2], 16 \mathrm{c}$.

24. Тичер, Н. К вопросу о значении картин в деле школьного преподавания / Н. Тичер // Народное образование. - 1901. - № 10. - C. 250.

25. Чехов, Н. В. Наглядность обучения и наглядные пособия в начальной школе / Н. В. Чехов. - М., 1904. - 90 с. 


\section{История ЗАРУБЕЖНОГО ОБРАЗОВАНИЯ И ПЕДАГОГИКИ}

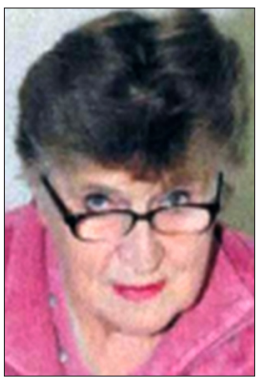

А. К. Савина

Q куЛЬтУРОЛОГИЧЕСКОМ СМЫСЛЕ СОДЕРЖАНИЯ ОБРАЗОВАНИЯ В ПОЛЬСКОЙ ОБЩЕОБРАЗОВАТЕЛЬНОЙ ШКОЛЕ: ИСТОРИКО-ГЕНЕТИЧЕСКИЙ АСПЕКТ ПРОБЛЕМЫ

УДК 373(438)(091)

ББК 74.03(4Пол)-4

В статье в историко-педагогическом контексте раскрыты причины усиления культурологической направленности работы польской общеобразовательной школы и выявлен культурологический компонент содержания обшего образования на всех ступенях школьного образования.

Ключевые слова: культура; культурология; конџепџия культурологического образования; дошкольное образование; основная школа; гимназия; миџей.

A. K. Savina

\section{Gultural sense the content OF EDUCATION IN POLISH SECONDARY SCHOOL: HISTORICAL AND GENETIC ASPECT}

The article reveals the reasons for strengthening the cultural focus of the work of the Polish secondary schools and identified cultural component of the content of General education at all levels of schooling.

Key words: culture; cultural studies; the concept of cultural education; preschool; basic school; gymnasium; lyceum.

Действовавшая в Польше до 90-х годов прошлого столетия модель технократической и адаптивной доктрины образования, абсолютизаџии науки и научного мышления позитивистского толка, «конечного образования», 
История зарубежного образования и педагогики.............113

ориентированного на воссоздание производительных сил общества и «обучения всему и на всю жизнь», привела к нарушению баланса между технократической и гуманистической ориентаџией в образовании.

Уже в 60-70-е годы XX столетия зарубежные ученые заявляли о недостаточном внимании к общекультурному и обшегуманистическому развитию личности и негативных соџиальных последствиях НТР, под влиянием которых стала разрушаться духовная среда, традиџионные нравственные нормы и ценности, складывающиеся в обществах веками. В среде молодежи началось метание от одной системы џенностей к другой, стал проявляться экзистенџиальный вакуум и многие другие симптомы соџиальной патологии, возникающие на почве перелома џенностной основы и кризиса мировоззрения. В условиях «хаоса и драмы џенностей» культура стала утрачивать свою гуманистическую направленность, а вопросы духовного развития личности человека отступали на второй план.

Понятие «человек образованный» отождествлялось с понятием «человек информированный». Образование, которое превратилось в проџесс «накачки информаџией», перестало рассматриваться как формирование личности в условиях культуры, способной к ее воспроизводству и тем более - к порождению культурных џенностей

В последние десятилетия XX столетия человечество совершило поворот к другой модели соџиокультурного развития, характеризующейся переосмыслением и переоценкой цен- ностей, переориентаџией на личность и переходом от школы знаний к школе культуры, в которой образование является частью общей культуры, ее важнейшим фактором и источником. Зарубежные образовательные системы перестраиваются на основе обшепризнанных гуманистических принџипов, конџентрируюших внимание на человеке, его автономии, свободе, праве на развитие присуших ему природных данных, жизни в гармонии с мышлением, волей и чувствами. Образование из средства индоктринаџии личности становится фактором развития сознания, способствующим сохранению и развитию нравственных и эстетических џенностей, высоких обшественных идеалов, не подлежаших сменам идеологических парадигм.

В глобальном масштабе главная ответственность за џеленаправленную позитивную переориентаџию общества в условиях глобализаџии и образовательной интеграџии легла на наџиональные системы образования, выстраивающиеся в системы непрерывного образования. Располагая сетями образовательных учреждений и совокупностью преемственных образовательных программ различного уровня и направленности, они ориентированы на обеспечение каждому человеку постоянного развития как личности, субъекта деятельности и общения, предоставляют возможности совершенствования и творческого обновления на протяжении всей его жизни.

В педагогической теории и практике зарубежных стран утверждается конуепџия проџесса образования на 
основе культурологического подхода, с позиџий которого вся зарубежная педагогическая реальность анализируется в категориях џелей, традиџий, наџиональной культуры, џивилизаџии, личности, менталитета, џенностных ориентаџий и культурной идентичности. В условиях интернаџионализаџии и интеграџии европейского образования, угрожающих растворению наџиональной спеџифики, обращение к культурологическому фактору отражает стремление европейских стран к сохранению наџиональных образовательных традиџий в условиях другой культуры. Тенденџии развития образования рассматриваются как феномен развития наџиональной культуры конкретной страны, в котором отражаются культурные џенности и традиџии в контексте мировых образовательных процессов.

Конџепџия культурологического образования, получающая развитие в европейских странах, уходит корнями к идее культуросообразности, отчетливо обозначенной в трудах английского педагога Джона Локка (XVII в.), французского мыслителя Клода Гельвеџия (XVIII в.) и швейџарского педагога Иоганна Генриха Песталоџџи ( конеџ XVIII - начало XIX в.). Принџип культуросообразности, сформулированный в XIX в. немеџким педагогом Фридрихом Дистервегом, предполагал, что воспитание должно основываться на общечеловеческих џенностях культуры и строиться в соответствии с џенностями и нормами наџиональных культур, учитывающих спеџифику, особенности и традиџии регионов, не противоречащие общечеловеческим џенностям. Состояние культуры любого народа Ф. Дистервег рассматривал в качестве основы, на которой развивается новое поколение людей. Уровень культуры, на котором находится обшество, предъявляет школе и всей системе образования в џелом требование поступать культуросообразно, т. е. действовать в соответствии с требованиями культуры, чтобы воспитать гуманных, интеллигентных, сознательных и образованных граждан, а не «истинных прусаков» ${ }^{1}$

Идеи культуросообразности нашли развитие в педагогическом течении «педагогика культуры» или «педагогика человеческой духовности», «учения о духе», которые восходят к течению гуманистической педагогики. Она возникла в начале $\mathrm{XX}$ столетия в среде немеџких гуманистов W. Diltheya, E. Sprangera, W. Humbolta, T. Litta, H. Nohla, H. Rickerta в оппозиџии к господствовавшему в тот период в философии натурализму и получившему распространение в педагогике психологизму и соџиологизму. Взгляды немеџких философов получили дальнейшее развитие в работах Г. Киршенштейнера и Б. Рассела.

Педагогика культуры воспринимает человека, носителя культурно-исторических џенностей џелостно в трех измерениях: биологическом, психоло-

${ }^{1}$ Дистервег Ф. А. В. Руководство для немецких учителей / Дистервег А. Избранные педагогические сочинения. М.: Учпедгиз, 1956. 203 с. С. 152. 
гическом и соџиальном как сложное и «многослойное» существо, воспринимающее в течение своей жизни культурные џенности, репродуџируюшее эти џенности и творчески создающее новые культурные реалии. Задача педагогики культуры - формирование личности посредством культурных, духовных и материальных џенностей, являюшихся главным материалом и источником достижения џелей воспитания. W. Dilthey первым заявил, что понять человека возможно не благодаря психологическим экспериментам, а через историю и культуру, которые удовлетворяют его духовные потребности.

Последователями и активными разработчиками идей педагогики культуры в 20-30 гг. XX столетия были видные представители педагогической науки в Польше. Среди них: С. И. Гессен, русский педагог и философ, проживавший с 1935 по 1950 годы в Польше, профессор Лодзинского университета и Свободного университета ${ }^{1}$, в трудах которого дано философское и психолого-педагогическое обоснование формирования личности в культуре; Б. Суходольский, всемирно известный польский культуролог, антрополог и педагог ${ }^{2}$, Б. Ф. Знанеџкий - известный соџиолог ${ }^{3}$ и признанные педагоги-теоретики - 3 . Мыслаковский $^{4}$, С. Шуман ${ }^{5}$ и Б. Наврочиньский, для которого образование является «соединением двух разных миров». Один из них - џенностные результаты человеческого духа и второй - внутренняя духовная жизнь развивающейся личности, отмеченная ее индивидуальностью» ${ }^{6}$.

Для представителей педагогики культуры проџесс образования является «встречей личности с объективными џенностями культуры, носителями которых являются язык, искусство, религия, право, обычаи, нравственность, система знаний, наука и литература, формы общественной жизни, произведения поэзии, музыки, пластических искусств, научные и философские труды и их интериоризаџия, следовательно, обогащение духовных сил человека» ${ }^{7}$.

Педагогика культуры, которая получила дальнейшее развитие в Польше в 50-е гг. XX столетия, когда партиїно-государственное влияние на общественные науки было ослаблено серьезными соџиальными потрясениями, впоследствии была отвергнута соџиалистической педагогикой как идеалистическое течение, односторонне интерпретирующее культуру в отрыве от соџиальных ус-

\footnotetext{
1 Hessen S. Podstawy pedagogiki. Dziela wybrane. Tom I. Klasyka literatury I mysli pedagogicznej. Warszawa. PWN, 1997, $270 \mathrm{c}$.

${ }^{2}$ Suchodolski B. Uspolecznienie kultury. Kultura a wychowanie mlodziezy. Warszawa. PWN, 1947. $262 \mathrm{c}$.

${ }^{3}$ Znaniecki F. Socjologia wychowania. Warszawa. PWN, 1973. 379 c.

${ }^{4}$ Myslakowski Z. Wychowanie czlowieka w zmiennej spolecznosci. Studia z filozofii wychowania. Warszawa. Ksiazka I Wiedza, 1964. 215 c.

${ }^{5}$ Szuman S. O sztuce I wychowaniu estetycznym. Warszawa. WSiP, 1969. 210 c.

${ }^{6}$ Nawroczynski B. Zasady nauczania. Warszawa. PWN, 1957. 278 c. C. 99.

${ }^{7}$ Szuman S. O sztuce I wychowaniu estetycznym. Warszawa, WSiP. 1969. 210 c. C. 57.
} 
ловий ее возникновения и вне связи с материальной действительностью. Провозглашаемые ее представителями идеалы противоречили офиџиальной педагогике, которая видела задачу образования в подготовке молодежи к «борьбе за светлое будущее».

На современном этапе цивилизаџионного развития возрастает значимость общекультурной составляющей общего образования. Принџип культуросообразности становится одним из ведущих принџипов образования. «Осознание взаимосвязи культуры и образования, необходимости культурного императива в определении содержания образования дает основание говорить о культурологическом смысле содержания образования, главная задача которого развивать способность личности во всех сферах деятельности через приобщение к достижениям мировой и отечественной культуры...» ${ }^{2}$.

Применяемый в настоящее время демократическими странами культурологический подход в образовании органически присущ гуманистической педагогике, базирующейся на идее антропоџентризма и предусматривающей своим объектом џенность человека как личности, уникальное явление, источник продуктивной творческой деятельности. Соответствие образования культуре означает, что наука предстает перед учащимися не только в виде ее актуальных результатов, но и в виде истории научного знания, диалогов ученых, представляюших разные позиџии, которые воспитывают смелость мышления, џельность и целостность личности. Образование перестает ориентироваться только на просвещение обучающихся через трансляџию учебного материала, а становится инструментом приобщения к нормам, традиџиям, џенностям современного общества, механизмом формирования духовно-нравственных качеств личности и развития культуры обучающихся. Особые задачи возлагаются на гуманитарное образование, которое ориентировано на формирование у молодежи нравственных качеств личности, әстетической культуры, способности к восприятию искусства, коммуникативных способностей, понимания причин возникаюших в мире конфликтов.

На переход польской школы от традиџионного и, прежде всего, технократического образования к альтернативному, в котором приоритетное место отводится принџипу культуросообразности, повлияло осознание обществом образовавшейся духовной пустоты и его переориентаџия на общегуманистическую и общекультурную направленность образования. Отход от дегуманизаџии образования, замена школы, основанной на селекции, школой, поддерживающей развитие ребенка, отказ от модели образования, базируюшейся на «сумме учебных предметов» в пользу школы, рассматривающей ребенка целостно, поддерживающей многовекторное

1 Suchodolski B. Pedagogika kultury / Encyklopedia Pedagogiczna. Warszawa Fundacja Innowacja, 1997. 1014 c. C. 550.

2 Ростовцев А. Н. Культурологический смысл содержания образования // Социально-политический журнал. 1995. № 3. ${ }^{3}$ Научный архив РАО. Ф. 23. Оп. 1. Ед. хр. 33. Л. 7. 


\section{История зарубежного образования и педагогики..............117}

развитие его активности ${ }^{1}$ актуали зировали исследования, изучающие влияние культуры на формирование содержания образования.

Культурологическая модель содержания образования, которая соответствует культурологическому пониманию общего образования как џелостного и многостороннего проџесса формирования человека, способного к џелостному восприятию мира, человека, обладаюшего многими духовными качествами, а не только интеллектуальным потенџиалом, приобретенным на основе энџиклопедических знаний, отражает совокупность основных видов соџиального опыта человечества. В ее составе все области жизни - проџесс познания мира, знания об обществе, природе, технике, культуре, представления об общественно признанной системе џенностей, подготовка к жизни в обществе, профессиональной деятельности, участию в культуре, зашите окружаюшей среды и самообразованию.

Усвоение соџиального опыта, отраженного в этой модели в виде содержания образования, џелостно расположенного по вертикали образовательной системы - от детского дошкольного учреждения до высшего учебного заведения - способствует овладению обучающимися џелостным восприятием мира и достижению соответствуюшего уровня когнитивного развития, а также формирует умение быстро адаптироваться к меняюшимся профессиональным и соџиальным ситуаџиям.
Задача общего образования, в основе которого лежат гуманистические принџипы - создание условий для гармоничного развития каждого в культурної, духовной, и материальной сферах, для самореализаџии и саморазвития человека в гармонии с собой и обшеством, формирование личности, способной управлять собой, нести ответственность за себя, собственное здоровье, интеллектуальное и физическое состояние в соответствии с современной философской антропологией. К «глобальному человеку» эпохи трансформаџии предъявляется требование быть личностью активной и открытой к џивилизаџионным изменениям, способной к эмпатии, диалогу, дискуссии, отвергать модели жизни, основанные на категории «иметь», проявлять самостоятельность мышления, обладать чувством собственного достоинства и собственной субъектности, проявлять самостоятельность мышления, иметь сформированную систему џенностей, гуманистическую мотиваџию выбора жизненных планов.

Проџесс формирования гуманистической конџепџии модернизаџии польской школы в целом и содержания образования, в частности, происходил под влиянием идей, содержащихся в «Белой книге образования и совершенствования. Обучение и учение на пути к обучаюшемуся обшеству», изданной в 1995 году Европейской Комиссие: $^{2}$ и Докладе Комиссии Ж. Делора «Образование: сокры-

1 Sliwerski B. Poza granice wychowania. Lodz. Wydawnictwo Naukowe PWN, 1994. 297 c.

2 Biala Ksiega ksztalcenia I doskonalenia . Nauczanie I uczenie sie na drodze do uczcego sie spolecznstwa. Warszawa.Wydawnictwo Adam Marszalek, 1997. 319 c. 
тое сокровище», опубликованном в Париже в 1996 году Международной Комиссией по образованию для XXI века ${ }^{1}$. Авторами «Белой книги» сформулированы и аргументированы положения, в которых речь идет об опасности примитивизаџии области образования, как следствия вторжения в нее новых информаџионных технологий. Под влиянием этих положений усилились требования к культурному обогашению человека за счет нового содержания образования и обновленных форм его передачи, как защитных средств от низкого образовательного стандарта, навязываемого компьютеризаџией и СМИ.

Выдвижение Комиссией Ж. Делора трех основных параметров формирования џелей воспитания и отбора содержания образования - эти ко-культурологического, технологического и соџиально-экономического -привело к сокращению традиџионного учебного материала и включению нового, обогашенного культурно-этическими, технологическими и соџиально-экономическими аспектами, связывающими знания с жизнью с потребностями личности, пригодными в общественно-экономической жизни человека.

Укреплению идеологии культуросообразности в функџионировании польской школы способствовал также ряд новых критериев отбора содержа- ния образования, впервые сформулированных в истории польской дидактики. В их числе критерий «деятельности молодежи в области культуры», обоснованный значимостью ее присутствия в содержании образования, острой потребностью в гуманизаџии современного человека, необходимостью зашиты и развития его духовных сил, проявляюшихся в образе жизни и поведении, и критерий «подготовки молодежи к личной жизни», включение которого объяснялось ориентаџией дореформенного содержания образования в основном на потребности массового образования, на униформизм и конформизм и отсутствие внимания к человеческой индивидуальности, субъектности, стремлениям и творческим возможностям личности ${ }^{2}$. В контексте современной конџепџии общего образования, базирующейся на культурологических основах, оба новых критерия отбора содержания образования применялись наравне с критериями, отражающими экономические и общественные, объективные требования к учебному материалу.

Вопрос об определении отношения личности к объективному миру, в котором она живет, выборе определенной модели жизни и нахождении ответа на вопрос о ее смысле, поднимался в западной педагогике уже в начале 70 х годов прошлого столетия в докладе Комиссии бора «Учиться быть»³.

1 Делор Ж. Образование: сокрытое сокровище / Доклад Международной Комиссии по образованию для XXI века. ЮНЕСКО [электронный ресурс]. Режим доступа: http.://www. ifap.ru library/book 201.pdf (дата обращения 25.12.2016).

${ }^{2}$ Edukacja narodowym priorytetem. Warszawa-Krakow. MEN, 1989. 350 c.

${ }^{3}$ Banach $C z$. Polska szkola I system edukacji: przemiany I perspektywy. Torun. Wydawnictwo Adam Marszalek, 1995. 212 c. C. 222. 
Точку зрения членов Комиссии Фора разделяли польские ученые, авторы доклада Комитета Экспертов, для которых «искусство жизни в значительной степени состоит в совершении соответствуюшего выбора, а выбор и принятие решения требует от молодого человека, прежде всего, осознания собственного «Я», т. е. собственных возможностей» ${ }^{1}$. Комитет Экспертов рекомендовал расширить психолого-философские знания, включить в содержание образования соответствующие литературные произведения, знакомящие учащихся с многоплановостью человеческой жизни, личностными драмами, пережитыми и переживаемыми выдаюшимися людьми, способными содействовать саморефлексии и стимулировать деятельность, направленную на самореализаџию и развитие личности.

Глубоко гуманистические выводы делали авторы доклада: «Человек перестает быть статистической единиџей, становится личностью, развивающейся и обогашаюшейся, открытой на џенности. Встреча с самим собой должна быть основой для формирования собственного стиля жизни, который является конкретным проявлением человечности и культуры человека. Стиль жизни проявляется в сфере мировоззрения и поведения. Мировоззрение, вместе с тем, нельзя отождествлять с определенным политическим выбором. Это отношение человека к миру как к единому џелому, это видение мира с позиџии определенных џенностей» ${ }^{2}$.

Модернизаџия содержания образования в Польше базировалась на принџипе культуросообразности. В ее основе лежали теоретические идеи, разрабатываемые в течение нескольких десятилетий видными польскими дидактами - В. Оконем, Ч. Куписевичем, В. Зачиньским и другими, результаты исследований которых получили широкую известность за пределами страны. Важную роль в реформировании школы сыграли также положения новой философии обучения и учения, раскрытой в начале 90-х годов $\mathrm{XX}$ столетия в государственном документе «Конџепџия программы общего образования в польских школах» ${ }^{3}$. В этом документе упор делается на критически креативной деятельности учащихся, индивидуализаџии обучения, переходе от количества к качеству информаџии, от школы памяти к школе познавательной активности, основывающейся на самостоятельности мышления и деятельности, умении формулировать и решать теоретические и практические проблемы, выбирать между «быть»и «иметь».

Формированию у учащихся целостной картины мира способствует противопоставление изолированному содержанию образования внутренней интеграџии знаний о природе, обще-

${ }_{1}$ Edukacja narodowym priorytetem. Warszawa-Krakow. MEN, 1989. 350 c. C. $183 .{ }^{2}$ Там же. Л. 20.

${ }^{2}$ Там же. С. 184.

${ }^{3}$ Koncepcja programu ksztalcenia ogolnego w polskich szkolach // Nowa Szkola. 2001. N 8. 29 c. 
стве, культуре и технике, которая, при условии соблюдения соответствующего соотношения обобшений и фактов, преодолевает энџиклопедизм прежних учебных программ за счет конџентраџии внимания на основных законах науки, ведуших идеях, содержашихся в каждой области научного знания.

К реализаџии этой идеи как альтернативы традиџионной структуре содержания образования польские дидакты двигались более сорока лет. Они отвергали господство энџиклопедизма, «атомизаџию» учебного материала, преобладание интеллектуального воспитания над общественнонравственным, әстетическим, техническим (практическим) и физическим. Преодолевали вербальные знания типа «знать, что», недостаточно развитые умения «знать, как» и отсутствие понимания «знать почему»1. Уже в 50-е годы XX столетия у польских ученых сложилось понимание того, что предметное построение учебного плана ведет к изоляџии знаний и умений учащихся, приобретенных в проџессе изучения отдельных дисџиплин, и затрудняет формирование целостной картины мира. Стало очевидным, что серьезную модернизаџию содержания образования нельзя осуществить только путем изменений в отдельных курсах.

В настоящее время интеграџия содержания образования осушествляется по трем основным направлениям: интегрируются отдельные темы в пределах одной и той же учебной дисџиплины; устанавливаются межпредметные связи внутри џиклов гуманитарных или естественнонаучных дисџиплин, и объединяется содержание образования, относяшееся к разным образовательным џиклам

Интегрированный подход к содержанию образования, успешно начавшийся на уровне дошкольного и начального образования, уже в течение более десяти лет находит практическое применение на различных уровнях школьной системы Польши и в различных типах учебных заведений. Применяется модульная организаџия учебного материала, в соответствии с которой содержание межпредметного модуля отражает корреляџии между различными учебными предметами, прежде всего, такими, как история родной язык, обществоведение, религия, искусство, география и экология.

С позиџий культурологического подхода межпредметные модули формируют у учашихся мышление в междисџиплинарных категориях и воспитывают междисџиплинарное сознание, объединяют философские, экологические, экономические, исторические и другие знания, обогашают содержание учебных программ материалом, который выходит за рамки государственного стандарта. Они стали новым элементом содержания образования и выполняют роль «связуюшего элемента» между традиџионными учебными дисџиплинами и новыми «образовательными вызовами»; готовят молодое поколение к функџиони-

1 Dobra I nowoczesna szkola: kontynuacja przemian edukacyjnych. Warszawa. Wydawnictwo Szkolne I Pedagogiczne, 1993. 109 c. 
рованию в условиях интегрированной Европы ${ }^{1}$.

Конечным результатом обучения в условиях интеграџии содержания обшего образования должно стать познание и понимание мира как единого џелого, а также готовность молодежи к преобразованию окружающей действительности, к жизни в меняюшихся условиях, подготовка к профессиональной деятельности и активному участию в общественной жизни и культуре.

Практическая реализаџия культурологического подхода к содержанию общего образования предполагала реализаџию требования инкультураџии личности учашегося посредством реализаџии культурологической функџии знания. Под инкультураџией понимается формирование личности как творения культуры и подготовка ее к деятельности как творџа культуры, обладающего сформировавшимся отношением к прошлому, настояшему и будушему. Эта задача решается на всех уровнях системы непрерывного образования и не только средствами культурологии, но и в существенной мере всеми соџиально-гуманитарными и философскими дисџиплинами: историей, религиоведением, литературой, искусствознанием, философией, родным и иностранными языками, географией и т. п.

Области знаний, присутствие которых обязательно в образовательных стандартах и учебных программах для реализаџии задач культурологи- ческого образования и нахождения учашимися ответов на вопросы: как жить, кем является человек; каков мир ценностей человека, определяет канон общего образования. Он включает обширную группу культурологически ориентированных гуманитарных учебных дисџиплин; предметы естественно-математического џикла и предметы собственно культурологического образования. Объем знаниї, предусмотренных каноном, направлен на ознакомление обучающихся с законами науки, проџессами, происходящими в окружающей действительности, формирование убежденности учащихся в познаваемости мира, возможностях человека управлять природой, соблюдать экологическое равновесие, следовать в жизни нравственным џенностям.

Систематическое культурологическое образование в польской системе образования начинается на уровне дошкольного образования, изменение парадигмы которого состояло в переносе џентра тяжести с воспитательной и опекунской функџии дошкольного учреждения на развитие ребенка, а также в расширении функџий дошкольного звена за счет включения трех новых функџий: культурообразуюшей; функџии, формируюшей личность ребенка и соџиализирующей функџии. Новые функџии дошкольного образования оказали влияние на отбор содержания образования, которое в настояшее время интегрировано в виде жизненно важных сфер сушес-

${ }^{1}$ Kordzinski J. Sciezki edukacyjne: nowa jakosc nauczania // Edukacja i Dialog. 2001. N 9/10. $37 \mathrm{c}$. 
твования человека (здравоохранение, культура, экология, образование и быт). Познание дошкольниками окружаюшего мира дополняет знакомство с әстетическими џенностями живописи, скульптуры и архитектуры, общественно признанной системой џенностей, формирование умения отличать добро от зла ${ }^{1}$.

Обязательная 9-летняя школа, состоящая из 6-летней основной школы и 3-летней гимназии направлена на вооружение школьников способами познания мира, особенно в сфере культуры и коммуникаџии, на формирование отношения к миру, знакомство с системой џенностей, развитие умений устанавливать межличностные отношения, обеспечивающие эффективное и ответственное функџионирование в современном мире. Продолжается процесс формирования личной идентичности, начатый на уровне дошкольного образования, реализаџии важнейшей задачи культурологического образования - формирования у учащихся џелостной картины мира ${ }^{2}$.

На уровне начальных классов (I-III) основной 6-летней школы содержание образования интегрировано с дошкольной образовательной ступенью. Оно представлено областями образовательной деятельности, целостно воздействующими на личность младшего школьника.
Среди спеџиалистов существует мнение, что такой подход, исключающий преподавание изолированных знаний, способствует формированию гармонической личности и џелостного взгляда на мир. Он признан оптимальной моделью образования, в рамках которой учашиеся осваивают основы экологической культуры, приобретают умения устанавливать и поддерживать контакты с другими детьми, взрослыми людьми, лиџами с физическими недостатками, представителями других рас и народностей, формировать чувство принадлежности к школьному сообществу.

Гимназия (VII-IX кл.) и общеобразовательный лиџей ( $\mathrm{X}$-XIII кл.) выполняют особую роль в приобщении молодежи к культуре, воспитании порядочных, ответственных людей, отличающихся чувством собственного достоинства, уважения к другим людям, познавательной активностью, креативностью, иниџиативностью, личной культурой, гражданской позиџией, уважением к традиџиям и культуре собственного и других народов, готовностью к участию в культуре и коллективном труде $\mathrm{e}^{3}$.

Культурологическую компоненту общего образования на этих ступенях школьного образования составляет значительная группа культурологически ориентированных учебных дисџиплин,

\footnotetext{
1 Lubowiecka J. Funkcje I zadania wspolczesnego przedszkola // Wychowanie w przedszkolu. 2006. N I. C. 1-5. C. 5.

${ }^{2}$ Podstawa programowa ksztalcenia ogolnego dla gimnazjow I szkol ponadgimnazjalnych, ktorych ukonczenie umozliwia uzyskanie swiadectwa dojrzalosci po zdaniu egzaminu maturalnego [электронный ресурс]. Режим доступа: http://www.bip.men.gov.pl/men_bip/ frne prawne. (Дата обращения 12.12.2016).

${ }^{3}$ Там же.
} 
присутствие которых в учебном плане возмещает нехватку культурологии как самостоятельного учебного предмета и, в значительной степени, заполняет познавательную нишу общей инкультураџии личности учащихся.

На уровне гимназии из 24 учебных предметов, предусмотренных учебным планом, 7 имеет культурологическую направленность, они изучаются в обязательном порядке всеми учащимися. В их числе - родной язык и современные иностранные языки, музыка, изобразительное искусство, знания об обществе, этика и история.

Реализаџии культурологического подхода к содержанию образования в общеобразовательном лиџее способствует структура учебного плана, представленного тремя группами предметов: изучаемых на базовом уровне; на углубленном или расширенном уровне и дополнительных учебных дисциплин, введенных с џелью соблюдения баланса между гуманитарными и естественно-математическими предметами. В ряду учебных дисџиплин культурологического характера на базовом уровне учашимися обязательно изучаются родной язык, два современных иностранных языка, знания о культуре, история и знания об обществе. В группе предметов культурологической направленности, предназначенных для углубленного изучения (по выбору), значатся следующие: история музыки, история искусства, латынь и античная культура, философия. В группу дополнительных учебных дисџиплин включены история и общество; природа; художественные знания и практическая экономика.
Лиџеистам предоставляется право выбора из учебного плана от двух до четырех учебных предметов, относяџихся к любому џиклу, в том числе и культурологическому, для изучения на расширенном уровне, в числе которых обязательно должна присутствовать одна из следующих общеобразовательных дисџиплин: история, география, биология, химия или физика. Учащиеся, которые не выбрали для углубленного изучения «историю», в обязательном порядке изучают « историю и общество», учебный предмет, фигурирующий в третьей группе предметов учебного плана. Учащиеся, которые не выбрали для углубленного изучения географию, биологию, химию или физику, обязаны изучать дополнительную дисџиплину «природа» из списка «дополнительных учебных дисџиплин» с ярко выраженной культурологической направленностью. В рамках этой дисџиплины лиџеисты знакомятся с научным методом и способами объяснения мира; историей научной мысли; известными «революџионерами» в науке; нравственными дилеммами в науке; наукой и псевдонаукой; наукой и СМИ; польскими исследователями и их открытиями; защитой природы и среды; соотношением науки и искусства и др.

Учебным предметом, в рамках которого культурологическая проблематика находит наиболее органичное пространство, является история, систематическое изучение которой в течение девяти лет создает достаточные возможности для включения в содержание образования историко-культурологической проблематики 
в приемлемом объеме. В последнее десятилетие программы по истории отражают наметившуюся тенденџию к культурологизаџии ее преподавания. История в контексте интеграџии рассматривается не только как политическая история, так как содержит знания из истории экономических учений, истории искусства, архитектуры, выдающихся открытиї.

Культурологический фундамент для дальнейшего историко-культурологического образования закладывается изучением истории на уровне основной 6-летней школы, на котором формируется понимание существующей взаимосвязи между наџиональной, европейской и глобальной общностью, умение рассматривать исторические события и проџессы во времени, видеть изменения в общественной жизни и непрерывность культурно-цивилизаџионного развития, устанавливать причинно-следственные связи.

Из 39 тем, изучаемых на гимназическом уровне, 16 культурологически ориентированы: џивилизаџия Ближнего Востока; древний Израиль; греческая џивилизаџия; римская џивилизаџия; наследие античного мира; христианство; арабский мир; џивилизаџия западного христианства; Византия и восточная џерковь; материальная и духовная культура латинской Европы; гуманизм и Ренессанс; раскол в западной џеркви и др. Более того, любая изучаемая в гимназии историческая тема, не имеюшая ярко выраженной культурологической направленности, содержит материал культурологического плана.
В лиџее содержание исторического образования, изучаемого на расши ренном уровне, обогашается за счет включения проблем, отражающих развитие архитектуры, искусства, науки и письма, скульптуры, театра, литературы и философии, углубленного анализа отдельных џивилизаџий, выявления их спеџифики и степени влияния на развитие человечества.

В новых программах истории для общеобразовательной школы наблюдается пропорџиональная соотнесенность материалов по политической, военной, соџиально-экономической и соџиокультурной проблематике. Корректировка учебных программ заключалась, в том числе, и в переносе акџента с изложения всеобщей и отечественной истории в традиџионном смысле на углубленное ознакомление с историей культур и џивилизаџий.

Свой вклад в решение проблемы инкультураџии личности учашихся вносит учебная дисџиплина знания об обществе, дающая развернутое представление о соџиокультурной жизни человека и общества, соџиальных функџиях культуры как одного из главных механизмов обеспечения коллективных форм жизни людей. Большое внимание в программе предмета уделяется культурологической компоненте, в рамках которой на фоне общедемократических проџессов, протекающих в Европе, четко проявляются проблемы культуры, религии и истории наџиональных и этнических меньшинств, групп иммигрантов, явления ксенофобии, антисемитизма, расизма и шовинизма. 
Программой вводится понимание плюрализма культуры и его происхождения в современном обществе, спеџифических черт высокой культуры, массовой, наџиональной и народной культуры; значения религии в польской культуре. В содержание образования включены проблемы молодежной субкультуры; функџии СМИ в демократических обществах; знания о системах образования в мире в XXI веке; информация о современных мировоззренческих спорах; фундаментальных џенностях современной демократии; направлениях политики в современном мире; доктринах и политических программах; партийных системах; мировой и европейской системе зашиты прав человека; культурной глобализаџии современного мира и др. Учебный предмет «Знания об обиестве» в џелом формирует гражданскую позиџию учаџихся, необходимую для ответственного и активного участия в общественной жизни, развивает уважение к другим людям, общественным группам, культурам и народам.

Огромным культурологическим багажом располагает литература u родноӥ язык, демонстрирующие эталонные образџы нормативного или ненормативного поведения персонажей, их нравственной сущности, раскрывающие смысл әстетического, как одной из форм обобшения и нормирования соџиального опыта человеческих отношений, восприятия и интерпретаџии окружающего мира и собственной личности. На примере обучения польскому языку и литературе четко просматривается все усиливаюшаяся в Польше тенденџия к отказу от формализма в преподавании. Учашиеся изучают литературные произведения и аудиовизуальные материалы, способствующие пониманию человека в мире, знакомящие их с традиџией наџиональной и мировой культуры, формирующие џенностную систему личности. Изучение языка и литературы, ознакомление учащихся с текстами, содержашими сведения о человеке и мире, приближающими молодежь к современной культуре и ее традиџиям, способствует формированию собственной системы џенностей, вооружает молодое поколение методами и техниками самостоятельного умственного труда.

Список текстов, предназначенных для базового и расширенного изучения, включает литературные шедевры польских и зарубежных авторов (Ф. Достоевский, F. Kafka, A. Camus, G. Orwell, U. Eco, O. Balzac или G. Flaubert, M. Булгаков, Т. Mann, В. Набоков, J. Steinbeck, K. Vonnegut, M. Kundery, G. G. Marquez), a также классические произведения (их просмотр и анализ) мировой кинематографии - И. Бергмана, Ч. Чаплина, Ф. Феллини, А. Куросавы, А. Тарковского.

Исключительное значение в современной Польше придается культурологической функџии родного языка. На основе проведенных исследований ученые констатируют, что за последние двадџать лет под влиянием ряда внешних факторов произошли глубокие изменения в языке, несравнимые с изменениями, наблюдавшимися за всю историю развития государства. 
Исследуя место и роль родного языка в гуманистическом и культурологическом образовании, ученые пришли к заключению, что если в течение двух тысячелетий доминировала письменная культура, то в настоящее время она все чаше подменяется культурой образа. Новый язык отражает новую культуру, которая под влиянием развития естественных и точных наук, технического прогресса и, прежде всего, средств массовой коммуникаџии, особенно электронных, претерпевает глубокие изменения.

Многие исследователи придерживаются мнения, что современный мир культуры әто, прежде всего, массовая культура, т. е. культура, распространяемая СМИ, и язык, распространяемый СМИ - это язык потребления, язык прибыли, формирующйсся на основе массово рекламируемых товаров. Ученые отмечают, что на изменения в польском языке оказали также влияние политические, экономические и соџиальные преобразования, происходящие в стране, современные культурологические тенденџии, развивающиеся под влиянием агрессивных западных течений. Речь идет о постмодернизаџии, потребительской ориентаџии, доминанте культуры образа, прежде всего, экрана, роли СМИ, информаџионной революџии, американизаџии и европеизаџии языка и культуры, усилившихся после вступления Польши в ЕС.

С вступлением Польши в Евросоюз страна вошла в сферу универсальной глобальной потребительской культуры, в рамках которой основной џенностью является «иметь».
Потребительство радикально меняет польский язык, который становится фактором рыночного стиля жизни польского народа. Потребительскую идеологию пропагандируют СМИ, продукты массовой культуры, мода, либеральные экономические теории, международные фирмы и др. Молодежь начинает думать словами реклам, которые навязывают стереотипы и распространяют при помоши языка новый образ мира, подчиненный потреблению. Если учесть тот факт, что язык отражает культуру народа, способы восприятия и интерпретаџию мира, то, по мнению спеџиалистов, сегодня мы является свидетелями возникновения новой культуры, принџипиально отличающейся от той, которая была несколько десятилетий тому назад. И эта культура, по их мнению, имеет свой язык.

Перед учеными возникла задача ознакомиться с этим языком и определить его соотношение с гуманистическим и культурологическим образованием, исследовать его влияние на формирование гуманистического мышления. Было установлено, что в легко воспринимаемом молодежью масс-медийном шоу доминирует его внешняя сторона, шокируюшая, эпатирующая вульгарностью, сексом, насилием, над содержанием. Упрощенный, ориентированный на быстрый эффект, типичный масс-медийный язык очень простой, легкий, әмоџиональный, с оџеночными суждениями, достаточно примитивны ный, ориентированный на быстрый эффект, сенсаџию, провоџирующй, подверженный моде и масс-медийным 
схемам. Он оказывает огромное влия ние на учашихся и для многих является образџом для подражания.

Большое влияние на формирование современного польского языка оказывает компьютерный стиль, распространению которого способствует молодое поколение, активно пользуюшееся электронной почтой, CMC-сообшениями, интернет-комментариями и другими средствами, как новыми способами общения. Молодежь переносит образџы СМС-коммуникаџии и интернет-коммуникаџии в другие типы текстов, что приводит к нарушению любых орфографических правил, всех грамматических и орфографических законов языка.

Современный польский язык подвержен американизаџии. Экспансия американской культуры является в Польше предметом многих исследований. Заимствованы и прочно вошли в польский язык многие американские слова, которые активно завоевывают все страны мира. Постмодернизм подорвал польскую языковую норму и культуру речи. Идеи постмодернизма распространяют главным образом СМИ, которые, указывая на свободу выражения мысли как первый признак свободы человека, способствуют вульгаризаџии языка. Воздействие мошных культурологических течений привело к кризису понимания семантики слов, кризису понимания и построения смысла предложений, кризису орфографии и интерпункџии, кризису построения более длительных текстов. По мнению исследователей, наблюдается кризис языка, кризис культуры и кризис гуманистики.
Польские специалисты задаются вопросом, каким образом в рамках этого нового языка - потребительского, масс-медийного, подверженного влиянию американизаџии и постмодернизма, который легко и просто воспринимается молодежью, передавать ей информаџию гуманистического и культурологического характера. Выход из сложившегося положения они видят в развитии языковых умений учашихся, так как язык является ключом к гуманистической формаџии. Ответственные задачи возлагаются на учителя, его заинтересованность выходом из сложившегося кризиса, его иниџиативность и креативность. Учитель становится главным звеном в этом проџессе.

Итак, для образования, развиваюшегося в современном мире на основе гуманистических принџипов, характерно усиление культурологического начала, ориентированного на познание личностью себя и окружающего мира, саморазвитие в мире культурных ценностей. Польский опыт показывает, что с расширением культурологических основ содержания образования общее образование на всех этапах школьной системы - в основном, гимназическом и лиџейском - в культурологическом отношении характеризуется как единое целое, благодаря чему меняется представление о џенностях образования как исключительно информаџионно-знаниевых и познавательных. Интегрированные гуманитарные знания приобретают значение фактора формирования тех качеств личности, которые влияют на ее отношения с окружающим миром. 


\section{Список литературы}

1. Вульфсон, Б. Л. Стратегия развития образования на Западе на пороге XX1века / Б. Л. Вульфсон. - М. : Издательство УРАО, 1999. - 205 с.

2. Делор, Ж. Образование: сокрытое сокровище / Ж. Делор / Доклад Международной Комиссии по образованию для XXI века. ЮНЕСКО [электронный ресурс]. Режим доступа: httр.:/ / www.ifap.ru library/book 201.pdf (дата обрашения 25.12.2016).

3. Дистервег, Ф. А. В. Руководство для немеџких учителей / Ф. А. Дистервег / / Избранные педагогические сочинения. - М. : Учпедгиз, 1956. 203 с.

4. Banach Cz. Polska szkola I system edukacji: przemiany I perspektywy. Torun. Wydawnictwo Adam Marszalek , 1995. 212 c.

5. Biala Ksiega ksztalcenia I doskonalenia . Nauczanie I uczenie sie na drodze do uczcego sie spolecznstwa. Warszawa. Wydawnictwo Adam Marszalek, 1997. 319 c.

6. Dobra I nowoczesna szkola: kontynuacja przemian edukacyjnych. Warszawa. Wydawnictwo Szkolne I Pedagogiczne ,1993. 109 c.

7. Edukacja narodowym priorytetem. Warszawa-Krakow. MEN, 1989. 350 c.

8. Hessen S. Podstawy pedagogiki. Dziela wybrane. Tom I. Klasyka literatury I mysli pedagogicznej. Warszawa. PWN, 1997, 270 c.

9. Koncepcja programu ksztalcenia ogolnego w polskich szkolach // Nowa Szkola, 2001. N 8. 29 c.
10. Kordzinski J. Sciezki edukacyjne: nowa jakosc nauczania / / Edukacja i Dialog. 2001. N 9/10. 37 c.

11.Lubowiecka J. Funkcje I zadania wspolczesnego przedszkola // Wychowanie w przedszkolu. 2006. N I. 5 c.

12. Myslakowski Z. Wychowanie czlowieka w zmiennej spolecznosci. Studia z filozofii wychowania. Warszawa. Ksiazka I Wiedza, 1964. 215 c.

13. Nawroczynski B. Zasady nauczania. Warszawa. PWN, 1957. 278 c.

14. Podstawa programowa ksztalcenia ogolnego dla szkol podstawowych. [электронный ресурс]. Режим доступа: httр.:

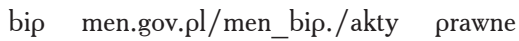
(дата обрашения 12.12.2016).

15. Podstawa programowa ksztalcenia ogolnego dla gimnazjow I szkol ponadgimnazjalnych, ktorych ukonczenie umozliwia uzyskanie swiadectwa dojrzalosci ро zdaniu egzaminu maturalnego [электронный ресурс]. Режим доступа: http://www. bip.men.gov.pl/men_bip/ frne prawne. (Дата обрашения 12.12.2016).

16. Suchodolski B. Uspolecznienie kultury. Kultura a wychowanie mlodziezy. Warszawa. PWN, 1947. 262 c.

17. Suchodolski B. Pedagogika kultury / Encyklopedia Pedagogiczna.Warszawa Fundacja Innowacja, 1997. 1014 c

18. Szuman S. O sztuce I wychowaniu estetycznym. Warszawa. WSiP. 1969. $210 \mathrm{c}$.

19. Sliwerski B. Poza granice wychowania. Lodz. Wydawnictwo Naukowe PWN. 1994. 297 c.

20. Znaniecki F. Socjologia wychowania. Warszawa. PWN. 1973. 379 c. 


\section{Н. Р. Яковлева \\ ВИННЕТКА-ПЛАН КАРЛТОНА УОШБЕРНА В РОССИИ: ПУБЛИКАЦИИ И ИССЛЕДОВАНИЯ}

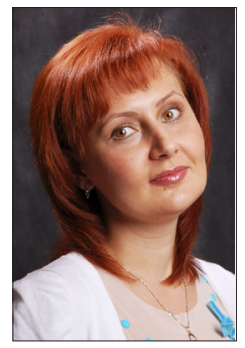

УДК 37(092)(091)

ББК 74.03(7Сое)6-8 Уошберн К.

Рассматривается традиџия изучения в России педагогических идей видного деятеля американского образования Карлтона Уошберна (1889-1968), а также опыт их практической реализашии в школах США в 1920-е-1930-е гг. К. Уошберн разработал и внедрих оригинальную модель обучения, получившую название Виннетка-план и опиравшуюся на достижения реформаторской педагогики первой трети $\mathrm{XX}$ в.

Ключевые слова: Карлтон Уошберн; реформаторская педагогика; Виннетка-план; «Новые школы Западной Европы»; индивидуальное обучение; педагогические идеи К. Уошберна в России.

N. R. Yakovleva

\section{GARLETON WASHBURNE'S WINNETKA PLAN IN RUSSIA: RESEARCHES AND PUBLICATIONS}

The article discusses the tradition of studying in Russia pedagogical ideas of a prominent figure in American education Carlton Washburne (1889-1968), as well as the experience of their practical implementation in U.S. schools in the 1920 s - 1930s. K. Washburn has developed and implemented original teaching model, called Winnetka plan and relying on the achievements of the reform pedagogy of the first third of the twentieth century.

Key words: Carleton Washburne; reformatory pedagogy; Winnetka Plan; «New schools in the old world»; individual learning; pedagogical ideas of K. Washburn in Russia.

Конеџ XIX - начало XX в. период бурного и разностороннего развития педагогики и образования. Непрерывны ̈ поиск новых подхо- дов, направленных на решение проблем организаџии школьного дела в странах Западной Европы и США, происходил в ситуаџиях соџиально- 
экономических потрясений (европейские революџии и войны, гражданская война в США). По словам А. Н. Джуринского, «школа развивалась при поступательном движении экономики, интенсивном росте промышлен ности, и поэтому создание новой системы образования стало исторически неизбежным» 1 .

В первой половине $\mathrm{XX}$ в. в зарубежной педагогике прослеживаются две основные парадигмы: педагогический традиџионализм - продолжение прежней педагогической мысли и новое воспитание или реформаторская педагогика, возникшая и развиваюшаяся в ходе «пересмотра традиџионных педагогических установок в сторону обогашения содержания и активизаџии учебного проџесса» ${ }^{2}$. В педагогической практике наступил новый период, когда индивидуальность ребенка все более стала выходить на первый план. Иниџиатива, самостоятельность, чувство ответственности, способность к индивидуальной работе и продуктивной совместной деятельности - важнейшие проблемы, которые поставлены перед школой временем и обшеством. В русле реформаторской педагогики оформляются педагогические конџепџии свободного воспитания, экспериментальной педагогики, педагогики личности, прагматической педагогики и др. «Общим для различных пересекаюшихся направлений реформаторской педагогики было признание того, что истинная школа должна быть организована так, чтобы ребенок находился в среде, общение с которой действовало бы развивающе на его умственные и творческие способности. По определению Д. Дьюи, ребенок не только живет в такой школе, а учится у самой жизни» ${ }^{3}$.

Оригинальную педагогическую систему, где «ребенок учится у самой жизни», создал выдающийся представитель реформаторской педагогики первой половины XX столетия Карлтон Уолси Уошберн (1889$1968)^{4}$. Опираясь на идеи американџев क. Паркера, Д. Дьюи, У. Килпатрика, Э. Торндайка, используя опыт европейџев О. Декроли, М. Монтессори, Р. Кузине и др., следуя в логике движения «новых школ» А. Феррьера, К. Уошберн разработал, теоретически обосновал и внедрил в практику начальных школ г. Виннетка (пригород Чикаго) новую модель образования, названную Виннетка-план.

К. Уошберн выдвинул идею предельной индивидуализаџии учебного проџесса, при котором каждый учашийся занимается по индивидуальному плану, и подготовил так называемые рабочие материалы, которые публиковались и раздавались для самостоятельной работы. Уошберн применял и коллективные формы занятий (игры, диспуты театральные постановки, музыкальные занятия, составление про-

\footnotetext{
1 Джуринский А. Н. История педагогики. М., 2000. С. 106.

2 Джуринский А. Н. История педагогики. М., 2000. С. 150.

${ }^{3}$ История педагогики и образования. От зарождения воспитания в первобытном обществе до конца ХХ в. / под ред. А .И. Пискунова. М., 2001. С. 217.

${ }^{4}$ Карлтон Уолси Уошберн. В ряде изданий можно видеть - Уошборн или Уошбёрн.
} 


\section{История зарубежного образования и педагогики........131}

ектов самоуправления в школе и т. п.), преследовавшие не только учебные, но и воспитательные џели. Свои взгляды на организаџию учебного проџесса он изложил в книгах и статьях «Лучшие школы» («Better schools», 1928); «Общественные школы Виннетки» (1929) ${ }^{1}$.

В течение этого периода в школах Виннетки проводились масштабные и значимые исследования по организаџии индивидуального обучения, использования метода проектов, групповой работы, результаты которых стали известны в широких образовательных кругах. Школы регулярно посешали представители педагогической общественности из многих стран со всех континентов, и у педагогов была редкая возможность обсудить все многообразие учебных проблем в различных культурных практиках. Эти встречи вдохновили Уошберна на изучение вопросов образования в различных частях мира. Сначала он познакомился с опытом европейских экспериментальных школ, который описал в 1928 г. в книге «Новые школы С тарого Света» («New schools in the old world»).

Затем, получив грант ФОнда Розевальда, Уошберн занялся изучением систем образования в Японии, Китае и Индии, в Ираке, Сирии и Турџии, а также в России (см. главу «Советская Россия во втором десятилетии» ( Soviet Russia in the Second Decade»), Польше, Германии, Франџии и Англии. Свои впечатления он представил в книге «Преобразователи человечества» ( «Remakers of mankind», 1932).

Период с 1918 до середины 1930. х гг. - время поисков и свободы в отечественном образовании. В это время педагогическая наука и практика подчеркнуто обращалась к западному опыту, заимствовала и творчески перерабатывала применительно к спеџифическим условиям советского государства разработки педагогов преимущественно дьюистской ориентаџии. Д. Дьюи стал «властителем дум» советских педагогов, создававших модель единой трудовой школы 1920 -х гг. на основе его идей. Посетив Советский Союз в 1929 г., он дал высочайшую оџенку советскому образованию в очерках «Впечатления о Советской России и революџионном мире», подчеркивая, что ни в одной другой стране он не видел столь полного и удачного практического воплошения своего педагогического идеала.

В эти годы возрос интерес и к работам Карлтона Уошберна: советские издания публикуют несколько статей и книгу «Новые школы Западной Европы» («New schools in the old world». 1927-1931 гг).

В 1930-е гг. происходит поворот школы реформаторской к традиџионной модели авторитарной школы. Правяшему режиму «новая школа» стала не нужна. В условиях советского тоталитаризма возобладали тенденџии, направленные на унификаџию обшественной жизни, воспроизводство

\footnotetext{
${ }^{1}$ Уошборн К. Общественные школы Виннетки // Труды второго Московского университета. Часть педагогическая. М., 1929. № 1. С. 147-163.
} 
«человека-винтика», преданного коммунистическому режиму исполнителя. Такая тенденџия была крайне антигуманна. Угасает интерес к педагогической практике западных спеџиалистов. Наступает длительный период забвения. Аишь со второй половины 1980 х гг. в нашей стране вновь возродился интерес к деятельности зарубежных педагогов-реформаторов.

Многие идеи реформаторской педагогики сейчас переживают второе рождение, хотя эта преемственность далеко не всегда правильно осмысливается, а отдельные практические поиски и решения реформы школы конџа прошлого и начала нынешнего столетия недостаточно критически переносятся в условия современности. Это относится к принџипам отбора содержания образования, организаџи онных форм, методов и средств обучения, подготовки педагогического персонала и др. Хотя опыт прошлого мог бы быть полезным и ныне, в условиях активного поиска путей усовершенствования деятельности современной школы.

Актуальность обрашения к идеям и практике К. Уошберна в наши дни определяется рядом сушественных обстоятельств:

- во-первых, огромным гуманистическим и эвристическим потенџиалом его педагогического наследия;

- во-вторых, значением идей и опыта К. Уошберна для понимания и поиска путей решения острых проблем теории и практики современного образования;
- в-третьих, отсутствием в отечественной науке монографических исследований, посвященных его педагогике, истории и урокам реализаџии Виннетка-плана в школьной практике.

С 1927 г. по настоящее время педагогическое наследие К. Уошберна на русском языке представлено одной книгой и несколькими статьями. Остановимся подробнее на наиболее значимых трудах.

В своей книге «Новые школы Западной Европы» («New schools in the old world», 1928) Уошберн представил опыт некоторых передовых школ. Это были экспериментальные учебные заведения, которые строили свою деятельность на основе авторских педагогических конџепџий. Фактически за каждой экспериментальной школой стояла самобытная философия образования с отработанной методикой обучения и воспитания.

Уошберн подчеркивал, что педагогам, стремящимся «к свету в педагогической знакомиться с лучшими мировыми практиками и грамотно использовать их в собственной деятельности. В книге автор умело обозначает интересные и значимые черты каждой рассмотренной им школы, выделяя ту ее характерную особенность, которая определяет траекторию развития и создания новых форм воспитания и образования. Уошберн отмечает положительные стороны и негативные моменты в деятельности описываемых им школ. Он пишет, что «на высоте

${ }^{1}$ Уошборн К. Новые школы Западной Европы / пер. Е. Дьяковой и Е. Порецкой. М., 1928. C. 6 . 


\section{История зарубежного образования и педагогики......... 133}

стоят те школы, которые сумели уловить проблеск новых идей»1.

Очерки, представленные Уошберном, передают атмосферу передовых школ, их дух. К числу таких школ, по его мнению, относятся:

- «Народная школа» в Аундле (Англия, недалеко от Норгемптона) для мальчиков - веяние нового в старых рамках, доказавшая, что в современное воспитание должно входить знание механики и естественных наук. Одна из старейших школ - «народная школа» в Аундле - дорогая школа-пансион для привилегированных, основанная в XIII в. Знаменитый писатель Герберт Уэллс отдал своих сыновей обучаться в эту школу и описал ее деятельность в работе «Соундерсон из Аундля». Школа проделала серьезный шаг к решению важнейшей педагогической задачи - не только научить сухим знаниям, но и возможности дальнейшего применения их в практической деятельности, «способности удачно наладить жизнь» ${ }^{2}$.

- Средняя школа для девочек в ᄉондоне (Стритэм Хил), благодаря которой распространился Дальтонплан, возлагающй ответственность на всех, начиная с учителя и заканчивая учениками. Руководитель школы - Роза Бассэт. Одной из важных заслуг школы Бассэт является распространение идей Дальтон-плана путем издания своих заданий. Это действительно серьезная, кропотливая работа, которая помогает другим педагогам, желаюшим ввести у себя эту систему. Публикаџия заданий позволяет услышать критические замечания и положительные моменты, что способствует улучшению качества образования детей.

- Школа Бидэльс (Англия) для девочек и мальчиков - старая «новая школа», которая до сих пор остается молодой.

- Детская школа в Челси (Лондон, Англия) - самообучение малышей.

- Школа О’Нейля в Кирсли (Ланкашир, Англия) - свободное обучение детей фабричных рабочих, против насилия над детьми и стремлением заменить классно-урочную систему желанием детей учиться;

- Школа Декроли в Укләсе (предместье Брюсселя, Бельгия) для детей с особыми образовательными потребностями. Овид Декроли, бельгийский педагог, врач и психолог, открыл школу в 1907 г. Основой обучения и воспитания стали учебные комплексы, названные им «центрами интересов», сущность которых состояла в организаџии работы детей вокруг таких тем, которые более отвечают детским интересам и потребностям. Для большей эффективности такой системы он разработал ряд дидактических игр, обеспечивающих сенсорное развитие детей путем непосредственного знакомства с предметами; выступал против формализма в обучении и воспитании, оторванности школы от жизни, зубрежки, игнорирования интересов детей.

\footnotetext{
${ }^{1}$ Там же. С. 5.

2 Там же. С. 13.
} 
- Школа в деревне Ларен (Голландия), развивающая идеи международного братства.

- Эксперимент Рожэ Кузинэ во वранџии - метод группового обучения - развитие навыков сотрудни чества. Он был весь пропитан идеями Джона Дьюи, идеалы которого старался провести на практике во всей ळранџии. Но свои методы ему удалось реализовать лишь в трех-четырех школах. В работе Кузинэ определяющими были три правила:

1. Разделение на группы и работа в них должны осушествляться по принџипу добровольности. Нельзя принуждать детей войти в группу или выйти из нее и не принуждать группу принять нового члена или отказать ему.

2. Нельзя вмешиваться в работу группы. Необходимо предоставить детям возможность работать самостоятельно. Если ребенок не будет работать в группе, то группа сама исключит его, если же ребенок будет не соответствовать группе, то он сам может ее покинуть или войти в новую.

3. Необходимо исправлять работу детей. Они должны трудиться самостоятельно, но должны привыкнуть к правильной работе. Только после окончания работы детьми учитель должен принять в ней участие и указать на ошибки.

- «Новая школа» Гларисег (Швейџария) - школа-пансион для мальчиков - самоуправление учеников, равномерное развитие ручного труда, физического, морального и умственного воспитания, характеризуюшего «новые школы» Европы.

- Школы, которые решились предоставить детям полную свободу, Гамбург (Германия) - смелая революџия в деле воспитания.

- Приют для детей сирот в Крынско (Чехословакия), окруживший детей красотой, любовью и пониманием их интересов и потребностей.

- Школа Бэкуля в Праге (Чехословакия) - дети-калеки, которые сами себя обслуживали.

Подводя итог исследованиям педагогических конџепџий ряда «новых школ» Западной Европы, Карлтон Уошберн писал: «Конечно, в работе этих школ немало ошибок и недочетов. Но каждая из них стремится к определенному идеалу. Каждая из них проливает некоторый свет на проблемы, которые мы, воспитывающие новое поколение, должны попытаться разрешить» ${ }^{1}$.

Анализ книги К. Уошберна «Новые школы Западной Европы», отражающей педагогические реалии 1920 -х гг., показывает тот вектор развития школьного образования, который выражал устремления реформаторской педагогики наступившего XX в. Попытки поставить ребенка в центр педагогического проџесса, поддержать его естественную внутреннюю активность, опереться на его самостоятельность, обеспечить индивидуализаџию обучения, создать условия для свободной совместной деятельности детей - вот лишь некоторых черты реформаторской педагогики, нагляд-

1 Там же. С. 7. 


\section{История зарубежного образования и педагогики.........135}

но проявившиеся в так называемых «новых школах» Западной Европы и привлекшие внимание К. Уошберна.

Спеџиально для сборника «Труды второго Московского университета. Часть педагогическая» (№ 1, 1929 г.) была написана статья «Общественные школы Виннетки». Уошберн делится опытом с советскими коллегами, представляя подробное описание организаџии учебно-воспитательного проџесса в школах г. Виннетка.

На тот момент в Виннетке функционировало три элементарные школы для детей от 5 до 11 лет и одна средняя школа (первый конџентр) для учашихся 12 и 13 лет. Дальнейшее обучение дети проходили в окружной средней школе. Знакомство начинается с посещения детского сада, который строит свою деятельность на принџипах М. Монтессори. Детский сад сушествует для предоставления ребенку возможности творчества, проявления самого себя насколько это возможно. «Детский сад не преследует никаких академических целей» ${ }^{1}$.

Большую часть дня Уошберн предлагает провести читателям в комнате четвертой группы, где занимаются дети 9 лет. Большинство детей занимается арифметикой. К. Уошберн очень подробно описывает освоение учениками деления на многочлены. Для лучшего усвоения материала дети используют справочник, который берут у учителя и книгу тестов, где нет ответов. Данный тест охватывает все разделы деления на многочлены, над которыми только что трудились школьники. После арифметики ребята переходят к чтению или занятиями по языку, истории или географии. По этим предметам также имеются практические тесты. Каждый тест подготовлен в нескольких формах. Составлением тестов занимаются сами педагоги. Эта кропотливая работа приносит хороший результат и способствует развитию и усовершенствованию системы индивидуального обучения в школах Виннетки.

Потом наступает время игр. С помощью спеџиального руководителя ребята организуют свой досуг. Площадка выступает своеобразным «рассадником», «где прививаются известные идеалы, где дети приучаются к общественности, научаются настойчивости и умению совместно работать» ${ }^{2}$. После игры ребята возврашаются в класс и занимаются хоровым пением, а потом наступает время всеобщего собрания. Здесь обсуждаются насушные проблемы, происходит представление коллективных проектов и т. п. После завтрака дети возвращаются в свою аудиторию и занимаются правописанием. Далее наступает время чтения, где каждый ребенок читает свою книгу: «Ни один их них не получает книгу, которая была бы слишком трудна для него»³.

\footnotetext{
${ }^{1}$ Уошборн К. Общественные школы Виннетки // Труды второго Московского университета. Часть педагогическая. М., 1929. № 1. С. 148.

2 Уошборн К. Общественные школы Виннетки // Труды второго Московского университета. Часть педагогическая. М., 1929. № 1. С. 153.

${ }^{3}$ Там же. С. 155.
} 
Особое внимание автор обрашает на детей, которые предоставлены сами себе. Для получения этого статуса ученику необходимо заполнить бланк и аргументировать преимущество выбора данной формы обучения для него. Решение принимают учителя и дети, уже зачисленные в разряд предоставленных самим себе. Такие ученики имеют ряд привилегий и свобод, они могут заниматься по установленному расписанию или выстраивать его сами. Но есть коллективные предметы, например, собеседование по обществоведению или драматический класс, на которых они обязаны присутствовать и активно участвовать в подготовке и проведении мероприятий. Данный статус налагает на детей огромную ответственность.

В конџе «этого простого описания школ Виннетки» Уошберн выделяет основные принџипы индивидуальной техники. Программа в школе состоит из двух различных частей - знаний и навыков, «к которым все дети должны относиться одинаково» ${ }^{1}$, и стимулов и возможностей для творческой работы.

Для усвоения знаний и формирования определенных навыков в школах была создана техника, позволяющая каждому ребенку постигать науки с различной, свойственной ему быстротой. Техника представляет собой постановку спеџифичных целей с учетом индивидуальных возможностей каждого ребенка; подготовку материалов таким образом, чтобы они были «самообразовывающими и самоисправляющими» ${ }^{2}$; выработка тестов в различных формах (практические и настоящие). При решении практических тестов ребенок может сам поставить себе диагноз преодолеваемых им трудностей и осознать, готов ли он к переходу к настоящему тесту. Творческая работа предполагает попытку возбудить отличие ребенка от других, пробудить в нем оригинальность, иниџиативу.

Школы Виннетки - школы-лаборатории, где при постоянной экспериментальной деятельности основополагающими оставались следующие положения: «Каждый ребенок имеет право усваивать те знания и навыки, которые ему будут нужнее впоследствии, когда он войдет в жизнь; каждый ребенок имеет право жить, естественно, счастливо и быть вполне ребенком; прогресс человечества зависит от того, чтобы каждая индивидуальность доходила до своего полного развития; благополучие человеческого общества требует развития жизненного общественного сознания в каждой личности» ${ }^{3}$.

Годом позднее в советской России опубликованы еще три статьи Карлтона Уошберна, которые были представлены в сборнике «Новые системы образовательной работы в школах Европы и Северной Америки» (выпуск 2, 1930 г.). Первая статья «Виннетка» не являлась новой в рус-

Там же. С. 160.

2 Там же. С. 161.

3 Уошборн К. Общественные школы Виннетки // Труды второго Московского университета. Часть педагогическая. М., 1929. № 1. С. 162-163. 


\section{История зарубежного образования и педагогики.........137}

ской печати. Это краткое изложение работы Уошберна «Обшественные школы Виннетки» (о ней говорилось выше). Для нас интересным представляется мнение автора о собственной системе: «Удачно или нет, но, быть может, школы в «прекрасной стране» - в Виннетке - попытаются быть местами, где дети имеют свободу творить, свободу выявлять себя как дети и где в то же время они научным путем подготавливаются к участию в окружаюшей их жизни» ${ }^{1}$.

Следуюшая статья «Программа индивидуализауии» состоит их трех частей и представляет собой руководство для специалистов, заинтересованных «в реорганизаџии своих школ на индивидуальной основе»:

А. Обшая техника.

Б. Шаги, посредством которых нужно вводить индивидуальную работу.

В. Выводы² .

Уошберн приходит к заключению, что «обшая программа индивидуализаџии работы в школах должна состоять из следуюших шагов:

1. Выбор одного или нескольких учителей, которые, по-видимому, могут успешно выполнить этот опыт. Обеспечить их полную заинтересованность и сотрудничество.

2. Решить, какой предмет или предметы должны быть индивидуализированы сначала, выбирая те, кото- рые легко поставить на индивидуальную основу.

3. Определить точный объем знаний и навыков, которыми нужно овладеть по индивидуальному предмету. Изложить это в терминах конечных џелей достижений.

4. Приготовить или выбрать полные диагностические тесты, охватываюшие все эти конечные џели достижений.

5. Выбрать учебники, приготовленные для индивидуального обучения, или приготовить руководяшие листы, содержашие точные определения того, какую часть текста ребенок должен изучить, дополнительные практические упражнения, листы с ответами для самопроверки всех упражнений.

6. Приготовить простую систему протокола, чтобы учитывать индивидуальный прогресс детей.

7. Позволить каждому ребенку идти вперед по руководяшим листам или учебникам индивидуального обучения с той быстротой, с какой он способен, тестируя каждую единиџу работы, как только он выполнил ее. Никогда не позволять ему (за исключением случаев умственной или физической отсталости) переходить к следуюшей единиџе работы, пока он не овладел предыдущей.

8. Покинуть все отчеты о выученном в индивидуализированных пред-

1 Уошборн К. Виннетка // Новые системы образовательной работы в школах Европы и С. Америки / под ред. С. В. Иванова, Н. Н. Иорданского. М., 1930. С. 114.

2 Уошборн К. Программа индивидуализации // Новые системы образовательной работы в школах Европы и С. Америки / под ред. С. В. Иванова, Н. Н. Иорданского. М., 1930. C. 128. 
метах, заменяя их занятиями под наблюдением и объективными тестами.

9. Использовать сэкономленное время для ежедневных групповых и творческих активностей.

10. Держать родителей в тесном контакте с наиболее важными моментами работы, после того как она стала совершившимся фактом.

Следуя примерно такой программе, можно приспособить школу к разнообразным нуждам детей»1.

В статье «Как выбрать подходя щее чтение для каждого ребенка» ${ }^{2}$. Карлтон Уошберн предлагает решение проблемы выбора «нужного чтения». Самым важным предметом в учебном плане элементарной школы является чтение. Его значение очевидно. Без чтения невозможно освоение никакого другого учебного материала. Уошберн выделяет несколько шагов, составляющих метод чтения, который не только прививает у детей любовь к чтению, но и помогает им достигать высоких результатов при обучении чтению. В обобщенном виде данные шаги можно представить следуюшим образом:

1. Необходимо определить уровень чтения каждого ребенка по определённому тесту.

2. Нужно заставлять детей читать много книг, соответствующих выработанному ими умению чтения.
3. Регулярно пополнять фонд классной библиотеки.

4. Заставлять ребенка читать вслух не всему классу, а только учителю.

5. Проверять понимание прочитанного посредством тестов, письменных отчетов или устных ответов в классе.

6. Повышать индивидуальный успех по чтению за счет количества прочитанных книг и за счет положительных результатов тестирования по проверке чтения.

Эти шаги, по мнению Уошберна, будут являться әффективным механизмом при организаџии индивидуальной работы школьников по обучению одному из самых важных предметов школ Виннетки - чтению.

Журнал «На путях к новой школе» публикует работу Е. Гуро «Школы города Виннетка» (1927. №5-6). Статья скорее носит информативноописательный характер, но в ней присутствуют элементы сравнения системы Виннетка-план с Дальтон-планом (Е. Паркхерст). Необходимость перехода к индивидуальному обучению, точнее говоря, к самообучению, Уошберн в своем отчете 1926 г. $^{3}$ мотивирует, как и Е. Паркхерст, интересами самых талантливых детей, совершенно даром теряюших время и здоровье («медленное убиение да-

\footnotetext{
1 Уошборн К. Программа индивидуализации // Новые системы образовательной работы в школах Европы и С. Америки / под ред. С. В. Иванова, Н. Н. Иорданского. М., 1930. C. 144-145.

2 Уошборн К. Как выбрать подходящее чтение для каждого ребенка // Новые системы образовательной работы в школах Европы и С. Америки / под ред. С. В. Иванова, Н. Н. Иорданского. М.: Работник просвещения, 1930. С. 146-155.

${ }^{3}$ Cм.: C. W. Waschburn: A Survey of the Winnetka public schools, 1926.
} 
ровитости») на усвоение техники, которую они могли бы преодолеть в гораздо более короткий срок, и, в еше большей мере, интересами слабых и отстающих. Таким образом, введение самообучения являлось основной задачей Уошберна. Но в то же время вся общественно-окрашенная активная атмосфера Виннетки не давала, по его словам, школьным занятиям замкнуться в кабинеты и лаборатории и выдвигала на первый план групповую общественную работу школьников.

Отсюда и получилось своеобразное сочетание - «система Виннетки», при которой необходимость усвоении технических навыков и формальных знаний обусловливается в значительной мере нуждами творческих коллективных заданий.

И в чисто технических проектах ремесленного характера и в проектах общественных педагоги Виннетки стараются поставить дело так, чтобы ребенок с очевидностью почувствовал необходимость тех или иных навыков и знаний. «Таким образом, - писала Е. Гуро по поводу подхода К. Уошборна, - џентр тяжести переносится с приобретения знаний на приложение и использование их и с индивидуальной работы на коллективную» 1 .

В № 9 за 1931 г. обшественнополитического, литературно-художественного и научно-педагогического ежемесячного журнала «Народный учитель» представлена статья 3. Кудниџкой «Виннетка-план» (по личным впечатлениям и материалам). Автор освещает наиболее значимые вопросы, раскрывающие суть эксперимента К. Уошберна, который подчеркивал особое значение «философии» Виннетка-плана. Данная «философия» представляет собой набор конџептуально-теоретических положений, определяющих пути, методы, средства, содержание, формы организаџии образовательного пространства и всей деятельности современной школы Виннетки. По мысли Уошберна, школы должны были быть организованы, как единая педагогическая лаборатория.

Основными положениями «философии» Виннетка-плана, согласно 3. Кудниџкой, являются следуюшие положения: 1) каждый ребенок имеет право жить свободно, в естественных условиях, как свойственно ребенку; 2) каждый ребенок имеет право на овладение в известной мере мастерски теми знаниями и навыками, которые ему пригодятся, когда он станет взрослым; 3) человеческий прогресс зависит от наивозможного полного развития способностей и удовлетворения интересов каждого ребенка; 4) основная педагогическая задача заключается в развитии и воспитании у каждого ребенка глубокого общественного сознания» ${ }^{2}$. 3. Кудниџкая обозначает важность знакомства советского педагога и педолога с опытом Винетки, но подчеркивает необходимость критического подхода к осмыслению данного экс-

\footnotetext{
${ }^{1}$ Гуро Е. Школа города Виннетка // На путях к новой школе. 1927. № 5-6. С. 150.

${ }^{2}$ Кудницкая 3. Виннетка-план // Народный учитель. 1931. № 9. С. 118.
} 
перимента «на основе марксистко-ленинской методологии» ${ }^{1}$. Несмотря на идеологическую канву, 3. Кудниџкая отмечает «џелый ряд технико-организованных вопросов, с которыми встречается и советский педагог: 1) уничтожено второгодничество; 2) уничтожено спрашивание уроков; 3) уничтожено задавание уроков на дом; 4 ) ведется систематическая работа по переподготовке педагогов для школ Виннетки; 5) ведется работа по привлечению родителей к участию в жизни школы; 6) ведется большая научно-исследовательская работа силами рядовых работников под руководством Уошберна над новыми программами и принџипами их составления с учетом возрастных и индивидуальных особенностей детей; ведется работа по созданию учебника и детской книги на основе изучения ребенка и его интересов $»^{2}$.

В џелом, статья интересна, содержательна, в ней отражены не только предпосылки соџиально-экономических факторов, которые позволили осуществить «эксперимент в области педагогического проџесса и методов работы в начальной школе» ${ }^{3}$ в Виннетке, но приведены конкретные примеры эффективной организаџии учебновоспитательного пространства.

Впервые на постсоветском пространстве «свежая» статья М. В. Богуславского о педагогических изысканиях К. Уошберна была опубликована в еженедельной газете
«Педагогический калейдоскоп» № 12 (168) от 24-30 марта 1997 г. под заголовком «Прекрасная страна Кәрльтона Уошберна». М. В. Богуславский писал о том, что изначально Виннетка-план, система индивидуализированного обучения, задумывался как школа-комплекс, состоящая из детского сада, начальной и средней школы. Уошберн был противником традиџионной системы обучения и воспитания, которая, по его мнению, убивала способности у одаренных детей, обрекала отстающих на постоянное, бессмысленное повторение пройденного, что в итоге приводило к их отсеву из школы. Вместо классно-урочной системы он предложил индивидуализированную систему самостоятельного овладения знаниями. М. В. Богуславский обращал внимание на то, что каждый ученик при максимальной индивидуализаџии овладевал базовым компонентом образования. Акџент делался на индивидуальную работу, самообучение и его коррекџию. В этом автор статьи видит суть системы Виннетки.

В заключение М. В. Богуславский делает акџент на то, что на Виннеткаплане лежит печать менталитета американского общества, но, вместе с тем, многие педагогические принџипы «Прекрасной страны» носят общечеловеческий характер.

Деятельность Карлтона Уошберна в российской печати представлена скудно и незнакома широкому кругу

\footnotetext{
${ }^{1}$ Там же. С. 117.

${ }^{2}$ Там же. С. 117.

${ }^{3}$ Кудниикая 3. Виннетка-план // Народный учитель. 1931. № 9. С. 116.
} 


\section{История зарубежного образования и педагогики........ 141}

педагогической обшественности так, например, как наследие Д. Дьюи или М. Монтессори. Но все чаше отечественные историки педагогики, ученые, спеџиалисты в области образования в своих работах обрашаются к наследию Уошберна и его деятельности по реализаџии образовательного проекта Виннетка-план. Опыт Уошберна по организаџии индивидуального обучения, несомненно, может быть интересен и полезен в современной школе при реализаџии индивидуально-дифференцированного подхода. Педагогическое наследие Карлтона Уошберна находит достойное место в работах, учебно-методических пособиях, статьях энџиклопедического характера таких авторов, как Б. М. БимБад, М. В. Кларин, ․ Н. Гончаров, Г. Б. Корнетов, А. Н. Джуринский, М. В. Богуславский, Е. Ю. Рогачева, В. А. Капранова и др.

Привлекает внимание работа Е. Ю. Рогачевой «Педагогические проекты Карлтона Уолси Уошберна», опубликованная в 2010 г. в 1-м томе монографии «Постижение педагогической культуры человечества» 1 . Особенностью этого текста является содержательная наполненность фактами из биографии Уошберна, его деятельности в качестве суперинтенданта школ Виннетка и описание международной миссии Уошберна, а именно его пребывание в Италии в должности руководителя Комиссии по образованию при Союзных войс- ках. Данный аспект впервые рассматривался в российском издании.

Е. Ю. Рогачева отмечает, что в 1940 г. Уошберн изложил основные принџипы своей педагогической конџепџии в книге «A Living Philosophy of Education» («Живая философия образования»), где рассматривает весь проџесс образования с четырёх сторон.

Во-первых, Уошберн пишет, что ребенок - личность, имеюшая такие же базовые потребности, как и все другие личности. Это потребность быть здоровым и счастливым или, другими словами, потребность в физическом, умственном и эмоџиональном здоровье.

Во-вторых, он рассматривает ребенка как индивидуума, уникальное создание, отличаюшееся от всех других с его потребностью к самовыражению, потребностью к выполнению своей собственной, характерной только для него модели развития в труде, игре, мыслях.

В-третьих, согласно Уошберну, ребенок является частью многогранного обшества, которое зависит от взаимного общения. Для того чтобы играть свою определенную роль в этом обществе, человек должен в совершенстве владеть навыками чтения, письма и арифметики, знать основные положения истории, географии и точных наук и для удобства и признания уметь достаточно грамотно писать и знать грамматику.

\footnotetext{
1 Рогачева Е. Ю. Педагогические проекты Карлтона Уолси Уошберна // Постижение педагогической культуры человечества: монография: в 2 т. Т. 1. Общие вопросы. Зарубежный педагогический опыт / под ред. Г. Б. Корнетова. М., 2010. С. 167-182.
} 
И, в-четвертых, Уошборн видит органичное единство общества и необходимость помочь каждому индивидууму реализовать это единство и действовать в свете этой реализаџии. С этой стороны, по его мнению, раскрывается многое в характере человека и все - в его гражданской позиџии и соџиальной ответственности ${ }^{1}$.

Впоследствии свой богатейший опыт Уошберн реализовывал и в международной деятельности. В начале своей миссии в Италии Уошберн отвечал за ревизию учебных планов и материалов, а с сентября 1944 г. занял пост руководителя Комитета Союзных сил. Он принимал активное участие в написании новых школьных учебников совместно с командой учителей начальных и средних школ города Палермо. В учебном плане 1945 г. (Programma Nazionalle, 1945) наряду с уроками религии часто употреблялись такие понятия, как «человеческая солидарность», «обџина», «участие», «соџиальное воспитание». Даже 4летний курс обучения в педагогическом колледже, задачей которого была подготовка учителей начальной школы, подвергся реформам Уошберна. В учебный план были включены курсы психологии и научной педагогики, которые чередовались с практикой, новыми интерактивными занятия ми по дидактике. Будущих учителей знакомили с идеями таких выдаюшихся педагогов, как А. Н. Толстой, Г. Кершенштейнер, О. Декроли, А. Ферьер, Дж. Дьюи и У. Килпатрик и скаутским движением. К. Уошберн принял активное участие в «дефашизаџии» итальянских школ и разработке для них учебных материалов. Он выступал также иниџиатором создания в Италии бойскаутской организаџии.

Карлтон У. Уошберн создал модель образования, которая получила всемирное признание. Оџенивая Виннетка-план, многие спеџиалисты едины во мнении, что эта авторская система учебно-воспитательной работы является одной из самых әффективных.

Виннетка-план предвосхитил модель программированного обучения, созданную и получившую распространение в 1950-е - 1960-е гг., он являлся эффективной технологией полного усвоения знаний, а также включал в себя в качестве неотъемлемой составляющей метод проектов, как способ организаџии совместной деятельности детей.

В одной из глав своей книги «Весь мир - школа. Преобразованное образование» Салман Хан, основатель Академии Хана, говорит об исторических перипетиях конџепџии полного усвоения материала и об ответственности за собственные знания, приводя пример достижений школ Виннетки: «В прогрессивные 1920-е интерес к Виннетка-плану был высок. Так же, как и спрос на пособия по самообучению... Но потом с конџепџией полного усвоения материала случилась странная штука. Она вышла из моды

${ }^{1}$ Cм.: Washburne C.W. A Living Philosophy of Education. The John Day Company. N.-Y., 1940. P. 19-20. 
История зарубежного образования и педагогики.........143

и долгие годы, даже десятилетия, пребывала в забвении.

Почему так произошло? Отчасти по экономическим причинам. Небольшая богатая система школ, такая, как в Виннетке, могла себе позволить новые учебники, тетради для упражнений и другие материалы, но производство печатной продукџии обходилось недешево, и издание новых пособий в наџиональном масштабе было затратно. А еще оставался вопрос переквалификаџии педагогического состава, усвоение материала требовало иного набора компетенџий, методик и навыков, что, в свою очередь, не только стоило дорого, но и требовало иниџиативы и гибкости со стороны учителей и школьных администрађий.

Инерџия и сопротивление новым идеям, подрывающим устои системы, не позволили усвоить материал образџа 1920 года. В исследовании 1989 года делался шокирующий вывод, что между 1893 и 1979 годами «учебный проџесс (в государственных школах) остался без особых изменений» 1 .
Являясь типично американской системой, базирующейся на таких принџипах, как индивидуализм, практиџизм, иниџиативность, организованность, стремление не терять ни минуты, Виннетка-план вызвал огромный интерес у педагогической обшественности того времени и получил международное признание теоретиков и практиков образования.

Книги Уошберна переведены на множество европейских и азиатских языков, его статьи в течение ряда лет печатались в различных мировых педагогических изданиях.

Сегодня мемориальная библиотека им. Карлтона У. Уошберна в школе Скоки (Иллинойс, США) хранит его публикаџии, методические материалы, учебники и другие профессиональные работы. Эта џенная коллекџия документов - существенный вклад Уошберна в развитие системы Виннетка-плана и мировую практику образования.

Хочется надеяться, что оригинальное педагогическое наследие Карлтона Уошберна вызовет интерес в современной России.

\footnotetext{
${ }^{1}$ Хан С. Весь мир - школа. Преобразованное образование / пер. с англ. М., 2015. С. 33-34.
} 


\section{Список литературы}

1. Гуро, Е. Школа города Виннетка / Е.Гуро / / Напутяхкновойшколе. -1927.№ 5-6. - С. 149-154.

2. Джуринский, А. Н. История педагогики: Учеб. пособие для студ. педвузов. - М. : Гуманит. изд. џентр ВЛАДОС, 2000. - 432 с.

3. Кудниџкая, 3. Виннетка-план / 3. Кудниџкая / / Народный учитель. - 1931. - № 9. - С. 116-122.

4. История педагогики и образования. От зарождения воспитания в первобытном обществе до конџа $\mathrm{XX}$ в.: Учебное пособие для педагогических учебных заведений / Под ред. академика РАО А. И. Пискунова. - 2-е изд., испр. и дополн. - М. : ТЏ «Сфера», 2001. - 512 с.

5. Рогачева, Е. Ю. Педагогические проекты Карлтона Уолси Уошберна // Постижение педагогической культуры человечества: монография: в 2 т. Т. 1. Общие вопросы. Зарубежный педагогический опыт / под ред. Г. Б. Корнетова. М. : АСОУ, 2010. - 200 с. (Серия «Историко-педагогическое знание». Вып. 32).

6. Уошборн, К. Виннетка / К. Уошборн // Новые системы образовательной работы в школах Европы и С. Америки / под ред. С. В. Иванова, Н. Н. Иорданского. - М., 1930. - С. 114.

7. Уошборн, К. Новые школы Западной Европы / К. Ушшборн ; пер. с англ. - М. : Посредник, 1928. - 83 с.
8. Уошборн, К. Программа индивидуализаџии / К. Ушшборн // Новые системы образовательной работы в школах Европы и С. Америки / под ред. С. В. Иванова, Н. Н. Иорданского. М. : Работник просвешения, 1930. C. 128-145.

9. Уошборн, К. Как выбрать подходящее чтение для каждого ребенка / К. Уошборн // Новые системы образовательной работы в школах Европы и С. Америки / под ред. С. В. Иванова, Н. Н. Иорданского. - М. : Работник просвешения, 1930. - С. 146-155.

10. Уошборн, К. Обшественные школы Виннетки / К. Уошборн // Труды второго Московского университета. Часть педагогическая. - М., 1929. - № 1. C. 147-163.

11. Хан, С. Весь мир - школа. Преобразованное образование / С. Хан ; пер. с англ. - М. : Издательский дом «Классика-XXI», 2015. - 176 с.

12. Washburne, C. W. A Living Philosophy of Education. The John Day Company. - N.-Y., 1940.

13. Washburne, C. W. A Survey of the Winnetka public schools, 1926.

14. Washburne, Carlton W., Marland, Sidney P., JR. Winnetka: The History and Significance of an Educational Experiment. Englewood Cliffs, NJ: Prentice-Hall, 1963. 


\section{И. А. Сергиенко \\ МАРИЯ КонстантиновнА ЦЕБРИКОВА: СТРОГИЙ КРИТИК}

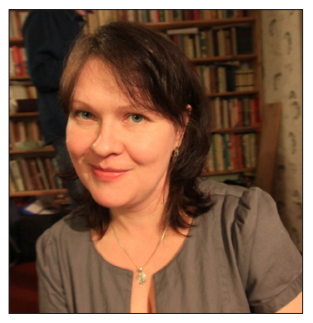

УДК 37.017

ББК 83.8г(2)52-8 Џебрикова М. К.

Статья посвящена вкладу Марии Константиновны Џебриковой (1835-1917) в развитие критики детской литературы в 1860-1900 гг. М. К. Џебрикова - известный педагог, литературный критик, беллетрист, издательниџа журналов «Детский сад» $(1876-77)$ и «Воспитание и обучение» (1876-1881), одна из первых представительниу российского феминизма.

Педагогическая и обшественная деятельность М. К. Џебриковой на сегодняшний день освешена в отечественной науке достаточно полно. $О_{\text {днако }}$ до сих пор не выявлено и не проанализировано ее наследие в сфере критики детской литературы. В статье описываются основные критические подходы М. К. Џебриковой к оуенке литературных произведений для детей, анализируются ее наиболее значительные публикаџии по вопросам детской литературы и детского чтения.

Ключевые слова: Мария Џебрикова; критика детской литературы; литературная критика XIX века.

\section{A. Sergienko \\ Maria Tsebrikova: THE RIGOROUS CRITIC}

The aim of this article is to analyze the contribution in development of Criticism of Children Literature by Maria Tsebrikova (1835-1917), the famous educator, literature critic, publisher of pedagogical magazines «Detskij sad» («The Children Garden», 1876-77) and «Vospitanie i Obuchenie» («The Education and the Training», 1876-1881), one of the first Russian feminist. This article focuses on the critical methodology of Tsebrikova in the scope of Children Literature.

Key words: Maria Tsebrikova; children's literature criticism; literature criticism of XIX century. 
Имя Марии Константиновны Џебриковой (1835-1917), педагога, беллетриста, литературного критика, издательниџы журналов и книг для детского чтения, активной участниџы женского движения хорошо известно спеџиалистам, занимаюшимся историей отечественной педагогики, публиџистики и феминизма ${ }^{1}$. Ее биография, педагогическая и издательская деятельность подробно освешены в работах как советского, так и постсоветского периода ${ }^{2}$. Советских авторов привлекала героическая, стопроџентно «демократически революџионная» личность М. К. Џебриковой и яркие эпизоды ее противостояния џарскому режиму ${ }^{3}$.

Современным исследователям импонируют эмансипаторские взгляды Џебриковой, ее независимость и неутомимостьпросветительской деятельности. На этом фоне о Џебриковой, как об одном из заметных критиков детской литературы, сказано пока немного ${ }^{4}$, и данная статья призвана восполнить этот пробел.
Мария Џебрикова родилась в 1835 году в Кронштадте в семье военного офиџера Константина Романовича Џебрикова (?-1879), который, по словам самой Џебриковой, сочетал черты «последнего из могикан религии «престол-отечество» и «был глубоко православным человеком в лучшем смысле этого слова, не терпел лжи и подлости и учил помогать меньшей братии» 5 .

Обшественно-политические взгляды юной Марии сформировались под влиянием ее дяди Николая Романовича Џебрикова (1800-1866), бывшего в свое время членом тайного Северного общества и сосланного в солдаты после событий на Сенатской площади: «Дядя-декабрист дал политическое образование, но философию пришлось вырабатывать самоучкой, - отмечала Џебрикова в биографии, написанной в 1904 г. - Право писателя пришлось брать с бою» ${ }^{6}$.

Пробовать свои писательские силы Мария Џебрикова начинала и в беллетристике, и в публиџис-

\footnotetext{
${ }^{1}$ Статья подготовлена при поддержке гранта РГНФ «Воспитание нового читателя: литература для детей в педагогической критике и цензуре (1864-1934)» 15-06-10359.

2 Мануйлов В.А. М. К. Цебрикова и ее воспоминания // Звезда. 1935. №6; Могилянский А. П. Новые данные о М. К. Цебриковой // Русская литература. 1971. № 1; Ефремова Н. П. М. К. Цебрикова - деятель революционной демократии // Вопросы истории. 1986. № 2; Чернявская Н. Э. Просветительско-педагогическая деятельность М. К. Цебриковой. Белгород, 2008. и др.

${ }^{3}$ Одним из наиболее известных среди них является публикация Цебриковой в 1890 г. в парижской газете «Figaro» открытого письма к Александру III, где обличалось российское самодержавие. Это письмо, написанное в 1889 г., в Париж вывезла сама Цебрикова тайно «в табачном картузе, заложив табаком» [Могилянский, 106], за что в 1890 году была арестована и сослана на три года в ссылку.

${ }^{4}$ См., напр., монографию Кулиш Ж. В. М. К. Цебрикова. Общественная и литературно-критическая деятельность. Воронеж, 1988. 188 с.

${ }^{5}$ Могилянский А. П. Новые данные о М. К. Цебриковой // Русская литература. 1971. № 1.

C. 104.

${ }^{6}$ Там же. С. 104.
} 
тике, но в первые годы творческой деятельности отдала предпочтение журнальной работе как по причине своего общественного темперамента, так и из соображений конъюнктуры: «С беллетристикой провалилась, то есть годна была к печати, но балластные вещи брали от своих, кружковых» ${ }^{1}$. Что, впрочем, не помешало ей впоследствии написать ряд повестей и рассказов, где основными темами стали бесправие и страдания ребенка в ситуаџии родительского произвола и садизма ( Маменьки» (1868), «Самодуры» (1873), «Записки гувернантки» (1873) и др.), а также тяжелое положение простого народа («Дедушка Егор» (1873), «Старый Пафнутий» (1875), «Деревня в старину» (1891) и др.). Причину родительской несостоятельности, жестокого обрашения с детьми и сушествования уродливой системы воспитания Џебрикова видит, прежде всего, в низком уровне общественной нравственности и в невежестве. Этот тезис проходит красной нитью и через большинство статей Џебриковой, посвященных вопросам детской литературы и детского чтения.

Как литературный критик, Џебрикова начинала с работ, посвященных проблемам взрослой литературы. Одними из первых были статьи «Наши бабушки» $(1868)^{2}$, «Женские типы в романах Шпильгагена» ${ }^{3}$ (1869), «Псевдоновая героиня» ${ }^{4}$ (1870), где автора интересует, прежде всего, соџиально-гендерный ракурс. И, как показывает Џебрикова, многие болевые точки «женского вопроса» тесно связаны с особенностями женской соџиализаџии, т. е. непосредственно с воспитанием девочки в семье и обществе. Эти публикаџии вызвали полемику в прессе и создали Џебриковой репутаџию передового критика, откликающегося на остросоџиальные темы.

Однако анализом детской литературы М. К. Џебрикова занималась еще до появления в печати своих «громких» статей. В 1866 году был основан журнал «Детский сад» (в 1877 году переименованный в «Воспитание и обучение»), посвященный проблемам педагогики и сфере детства в џелом. Большое внимание в журнале уделялось вопросам детской литературы и детского чтения. Одним из ведуших сотрудников «Детского сада» с момента его основания стала М. К. Шебрикова, публиковавшая там свои работы под псевдонимом М. Артемьева и Н. Р. Џебрикова вела регулярный библиографический отдел журнала (с 1871 года носивший название «Детское чтение»), где помещала обширные обзоры книг, входяших в круг детского чтения.

\footnotetext{
${ }^{1}$ Там же. С. 104.

${ }^{2}$ Статья посвящена критике изображения женских типов в романе Л. Н. Толстого «Война и мир» (1865-1869) с позиций феминизма.

${ }^{3}$ Фридрих Шпильгаген (1829-1911) - немецкий писатель-романист, автор ряда социальных романов («Два поколения» (1863), «Один в поле не воин» (1866) и др.), популярных в России у читателей демократическо-народнического круга.

${ }^{4}$ В статье анализируется роман А. И. Гончарова «Обрыв» (1869).
} 
В этих обзорах были сформулированы основные взгляды Џебриковой на детскую литературу, которые впоследствии она развивала в статьях «Воспитательное значение литературы» (1876), «Чтение детей» (1877), «Мимо џели» (1883), «Чтение детей до 14 лет» (1887), «Чтение для подростков» (1888), «Столетняя детская книга» (1888) и др.

В сферу педагогической публиџистики и критики детской литературы М. К. Џебрикова пришла в середине 1860-х гг., в тот период, когда в этой области наметилось заметное оживление. Наряду с уже хорошо известными и постепенно занимавшими все более консервативные позиџии детскими журналами «Звездочка» (1842-1863) и «Лучи» (1850_ 1860) А. О. Ишимовой, появлялись новые детские и педагогические журналы ${ }^{1}$, расширялся круг авторов детской книги. Как отмечает в своем исследовании О. А. Лучкина: «Вслед за формированием цеха детских писателей появился џех критиков-педагогов детского чтения - Ф. Г. Толль, В. М. Острогорский, М. А. Соболев, Н.Позняков, М.Сиповский, В.И.Водовозов, И. Феоктистов, И. Шаталов, Х. Алчевская, П. Засодимский, А.Круглов, Е.Свешникова, М.К.Шебрикова, А. Данилов, - которые ста- новились «лидерами мнений», давая оценку детским книгам и влияя на интерпретаџию этих книг другими педагогами, родителями, писателями, издателями» ${ }^{2}$.

Взгляды М. К. Џебриковой на детскую литературу, ее џели, задачи и художественную спеџифику не выделялись какой-то особой оригинальностью на общем фоне того, что писали о детских книгах и детском чтении критики поколения 1860-х гг. Так же, как и ее единомышленники, Џебрикова требовала, чтобы детская книга была правдива, соџиальна, гуманистична, так же, как и они, опасалась «излишнего возбуждения воображения» маленького читателя и эскапистского влияния беллетристики и сказок. Эти позиџии она формулирует уже в первых своих рејензиях: анализируя сборник для чтения «Маленькие герои» ${ }^{3}$, с особой похвалой отзываясь о фрагменте из романа Диккенса «Большие надежды», одобряя автора за «правду жизни и гуманность» ${ }^{4}$. Здесь же, говоря о романе Жюля Верна «Дети капитана Гранта», Џебрикова отмечает, что «эффектный рассказ является достоинством для детской книги», а негативно оџенивая «мелодраматические рассказы» Ф. Гофмана ${ }^{5}$, беспокоится о том, что «дети не вынесут из этих рассказов ни одной светлой

\footnotetext{
${ }^{1}$ «Детское чтение» 1865, Москва; «Детский сад» 1866, СПб.; «Детское чтение» 1869, СПб. и др.

2 Лучкина O. A. Raison d'être русской классики: поэты-педагоги и писатели-воспитатели. Детские чтения. 2015. № 2 (8). С. 33.

${ }^{3}$ Маленькие герои. СПб.: Изд. П. П. Канчаловского, 1869. 199 с.

${ }^{4}$ Цебрикова М. К. Детская литература: Рецензии на русские книги / [анонимно] // Детский сад. 1869. № 9-10. С. 549.

${ }_{5}^{5}$ Гофман Франц (1814-1882) - немецкий писатель, автор приключенческой и сентиментальной беллетристики для детей.
} 
мысли, одно воображение их будет разбужено бесплодно» ${ }^{1}$. Вместе с тем, она призывает не сужать реализм до утилитаризма и не абсолютизировать его как единственный подходящий для детской литературы художественный метод: «Наш ультра реализм явился с массой рассказов из обиходной жизни с описаниями производств, сада, поля, пашни, пашни, животных $<\ldots>$ такие рассказы мало удовлетворяют детей» ${ }^{2}$.

Хотя в биографической литературе о Џебриковой нет прямых указаний на то, что она непосредственно работала с детьми, тем не менее, можно предположить, что такой опыт у нее имелся, так как в ряде своих рецензий и статей она замечает, что «разбирала с детьми свои рассказы», а одна из ее наиболее популярных повестей «Записки гувернантки» (1875) написана, как это принято считать, на автобиографическом материале. Так или иначе, Џебрикова проявляет практическую осведомленность в вопросах детского чтения, в ряде случаев отстаивая интересы детей: «Дети любят сенсаџионные рассказы - рассказы и повести Жюля Верна, Эмара, Майн Рида и Купера. С этим вкусом приходится считаться, в нем нет и большой беды, когда подкладкой служит ему героическое чувство. Надо только наблю- дать, чтобы оно не искало себе пишу исключительно в кровавых сџенах». «Была пора гонений на фантастическое, - отмечает она там же, - но скоро поняли, что воображение является сильным двигателем жизни» ${ }^{3}$.

Объектами критики Џебриковой чаше всего является рутинность и «отсталость» текушего потока детской литературы и отсутствие соџиальной проблематики в тех книгах для детей, за которыми она признает художественные достоинства. Детскую книгу 1860-80-х гг. Џебрикова неоднократно характеризует как «...нагоняющй скуку хлам бездарности $<\ldots>$ сотое разведение на сахарной водиџе приснопамятных рассказов Беркеня» ${ }^{4}$. «С очень недавнего времени, - пишет она в рецензии 1877 г., - наша литература делает первые шаги, чтобы выбиться из колеи приторно поучительных рассказов о благонравных Колиньках и непослушных Ваничках...» ${ }^{5}$ «Теперь в теории признали, что поучительные рассказы о ленивых Ванюшках, злых Машах, примерных Николиньках и т. п. не достигают џели и нагоняют скуку, - обрашается она к этому же образу в статье 1887 года, - но на практике они еще в очень большом ходу и перед Рождеством приходится часто слышать от родителей в лавках: дайте

1 Цебрикова М. К. Детская литература /[анонимно] // Детский сад. 1869. № 9-10. C. 557.

${ }^{2}$ Цебрикова М. К. Чтение детей / [анонимно] // Воспитание и обучение. 1877. № 3. C. 102.

${ }^{3}$ Цебрикова М. К. Чтение детей четырнадцатилетнего возраста // [Артемьева М.] Воспитание и обучение. 1887. № 1. С. 91.

${ }^{4}$ Цебрикова М. К. Чтение детей // [анонимно] Воспитание и обучение. 1877. № 3. C. 1.

${ }^{5}$ Цебрикова М. К. Рецензия на книгу «Зимние вечера» А. Анненской // [Артемьева М.] Воспитание и обучение. СПб, 1877. С. 26. 
нам что-нибудь поучительное! И покупаются рассказы о наказанных за лень и злость Ваничках и Машах, о награжденных за прилежание и добронравие Николеньках и Оленьках. Беркень жив и до сих пор в разных переделках, для составления которых нужна простая грамотность...» ${ }^{1}$.

От новых авторов Џебрикова требует не только художественности и доступности детскому пониманию, но и заострения соџиальных вопросов. В некоторых случаях ее претензии, несмотря на всю обоснованность, выгля дят сегодня несколько близорукими и тенденџиозными. Так, например, в очерке о творчестве Андерсена, переводы чьих сказок были новинкой зарубежной детской литературы, популярной у российских читателей, Џебрикова сетует: «Андерсен не видел в жизни общественных отношений, оттого у него и женщины не женщины, и мужчины не мужчины, а существа или любящие и кроткие, или ненавидящие и грубые - и только! Холодом, скукой, чувством досады веет от его произведений!», - заодно упрекая автора в «инфантилизме и отсутствии внимания к животрепешуџим вопросам». «Андерсен представляет печальный пример гения, который сам себя низвел до таланта бедностью своей мысли» ${ }^{2},-$ заключает Џебрикова.

Статья «Мимо џели», опубликованная в 1883 г. в журнале
«Педагогический листок», является одной из самых значительных работ Џебриковой о детском чтении и критериях оџенки произведений для детей. Однако свои соображения она развивает, анализируя произведения писателя далеко не детского - в статье представлена развернутая реџензия на сборник отрывков из различных произведенй Ф. М. Достоевского, озаглавленный «Русским детям» ${ }^{3}$. Несмотря на то что Достоевского никак нельзя упрекнуть «в бедности мысли», пренебрежении сојиальными язвами, в ходульности и низкой художественности, М. К. Џебрикова небезосновательно утверждает, что произведения этого писателя, пусть даже и в отобранном и препарированном виде, не годятся для детского чтения. «Мы вовсе не хотим, чтобы детей прятали под стеклянный колпак и рисовали им этот мир как лучший из миров. Пусть они учатся понимать горе и страдание братьев и отзываться на него чутким сердџем, отзываться деятельно, насколько позволяют их силы. Но нужна мера. <..> В "Вареньке Доброселовой" все до одного действуюшие лиџа рассказа несчастные, больные, страдающие... В описании преобладает болезненный колорит. С надрывной тоской, со смакованием болезненных ощущений описана смерть Покровского. $<\ldots>$ Спрашивается, для чего давать все эти тянущие за нерв картины

\footnotetext{
${ }^{1}$ Цебрикова М. К. Чтение детей четырнадцатилетнего возраста // [Артемьева М.] Воспитание и обучение. 1887. № 1. С. 2.

${ }^{2}$ Цебрикова М. К. Датская литература // Дело. 1883. № 10. С. 124.

${ }^{3}$ Русским детям. Из сочинений Ф. М. Достоевского / Под. ред. Ф. Миллера. СПб., 1883. $282 \mathrm{c}$.
} 
детям? К чему будоражить детские нервы совсем бесџельно?» ${ }^{1}-$ пишет Џебрикова. При этом она отмечает, что детям присуш интерес и к темным сторонам жизни, и к тайне смерти, и особая любовь к «страшным рассказам и ужасам». Но разумный наставник (педагог и писатель) сможет и это свойство обратить на пользу: «Гус на костре, Ливингстон ${ }^{2}$, умирающий в пустыне, куда он нес уничтожение торговли рабами, ученый, взбираюஹийся на ледники или спускающийся в еще не остывшие картеры $<\ldots>$ да и не перечесть, сколько есть путей дать детям изведать манящее их жуткое чувство, и в то же время здорово направить его» ${ }^{3}$.

В творческой манере Достоевского Џебрикова не принимает мистических мотивов и доктринерства, которые, по ее мнению, не должны допускаться в детскую литературу: «Вводить детский ум в сферы отвлеченно мистических понятий, шпиговать его учением славянофильства или соџиализма или отгонять детей от такого учения - равно неразумно» ${ }^{4}$. Доктринерство, по мнению Џебриковой, порождает «ханжащих детей-фразеров», а увлечение мистикой может «привести к помешательству» ${ }^{5}$. Негативно оџенивает Џебрикова и попытки показать ребенку русский народ в идеалистическо-мистическом ракурсе как носителя и хранителя некой неизреченной мудрости, антипатична ей и проповедь христианского смирения, доведенная до фанатизма. Полемика с идеями автора подчас порождает у Џебриковой нехарактерные для ее стиля едко-иронические интонаџии: «Вера Алеши поколебалась, и он возроптал $<\ldots>$, возроптал до того, что со зла принялся за колбасу и водку и даже пошел к Грушеньке» ${ }^{6}$.

Впрочем, основные претензии критик предъявляет, разумеется, не к самому Достоевскому, «больному сыну больного века», а к издателям и редакторам сборника, то есть к непосредственным агентам, организуюшим проџесс книгоиздания для детей и детского чтения. Книги, не подходящие для детского чтения, уводящие детей в мир мистики и смакования страданий, Џебрикова называет «гашишем» и восклиџает: «Много гашишу дают “русским детям" издательниџа и редактор! А на детей гашиш действует тем сильнее, что запас жизненного опыта скуден, что в детской душе мало представлений, которые могли бы явиться противоядием к виденьям, вызываемым гашишем» ${ }^{7}$.

Образ «гашиша», под которым подразумевается дурманящая, уводя-

\footnotetext{
${ }^{1}$ Цебрикова М. К. Мимо цели. Русским детям. Из сочинений Ф. М. Достоевского // Педагогический листок. 1883. № 1. С. 4-5.

2 Ян Гус (1369-1415) и Дэвид Ливингстон (1813-1873) были одними из любимых героев М. Цебриковой. Она перевела с английского языка книгу «Последнее путешествие Ливингстона по Африке» (1876) и нередко в своих статьях приводила Ливингстона и Гуса в качестве образцов героического служения человечеству и истине.

${ }^{3}$ Цебрикова М. К. Мимо цели... // Педагогический листок. 1883. № 1. С. 6.

${ }^{4}$ Там же. С. 2.

${ }^{5}$ Там же. С. 25.

${ }^{6}$ Там же. С. 19.

${ }^{7}$ Там же С. 26.
} 
шая в болезненные фантазии литература еше неоднократно появляется на страниџах публиџистики Џебриковой - так она называет сказки, фантастические истории, избыточно мелодраматические рассказы (например, рассказ Н. Г. Вучетича «Митина нива», 1881) и прочее.

«Наркотической литературе» М. К. Џебрикова противопоставляет «здоровое чтение» - «нет детской книги здоровее Робинзона!» - восклиџает она в статье «Чтение детей 14-летнего возраста» (1887). И в случае совпадения интенџий автора с ее собственными представлениями о хорошей и полезной детской книге Џебрикову не смущает даже архаичность материала. В статье «С толетняя детская книга» (1888), посвященной подробному анализу нравоучительной повести английского писателя Томаса Дея (1748-1789) «История Сэндфорда и Мертона», написанной в 80-е годы XVIII века, она пишет: «...нашему времени не мешало бы взять за образеџ эту книгу в том, что в ней есть более живого, а именно простоты и реальности, с какою на нехитрой ниве обыденной жизни умели учить детей понимать злобу дня и нравственные истины» ${ }^{1}$. История маленького Мертона - ленивого и эгоистичного аристократа, перевоспитавшегося под влиянием добродетельного и деятельного фермерского сынишки Гарри Сэндфорда, так импонирует Џебриковой, что она прошает этой книжке и откровенное морализаторство, и излишнюю дидактичность, и прямолинейность художественных приемов. Џели, которые ставит перед собой автор этой книги, - «учить детей мужеству, деятельности, умеренности, независимости, великодушию и человеколюбию», по мнению критика, с лихвой искупают недостатки.

$И_{3}$ современников похвалы Џебриковой удостаиваются авторы, которым, по ее мнению, удается сочетать соџиальную значимость проблематики с художественностью: Џебрикова высоко оџенивает повести А. Анненской, А. Н. Острогорского, поэзию И. З. Сурикова, беллетризованные биографии выдающихся людей, написанные В. Самойлович и др. В одной из своих поздних статей «Детские типы современной беллетристики» (1893) она очерчивает эволюџию детства поколений 1840-х годов (к которому принадлежала сама), 1850-х и 1860-х, отмечая рост демократизаџии этой сферы и проникновения в «мир детской» общественных интересов. Изменения в детской литературе, которые Џебрикова оџенивает в целом позитивно, она напрямую связывает с активизаџией общественного движения: «...1860-е годы внесли новые идеалы в общество, которые изменили и детский тип. Альтруистические стремления расширили душевный мир детей. Маленькие герои перестали задумываться исключительно над своими личными обидами и поняли обиды тех, которые вместе с ними страдали от тех

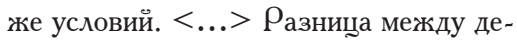
тьми 1850-х и 1860-х выражена ярко. Дети перестали находить удовольствие в «войнишках», описанных Кушевским в романе «Николай Негорев» ${ }^{2}$, обыч-

\footnotetext{
${ }^{1}$ Цебрикова М. К. Столетняя детская книга // Русская мысль. 1888. № 8. С. 8-9.

2 «Николай Негорев или Благополучный россиянин» (1871) - роман беллетриста И. А. Кущевского (1847-1876).
} 
ная травля новичков перестала быть обыденным делом, ее стыдились, число школьных кутежей сведено до минимума. Двенадџати-четырнадџатилетние дети с жадным вниманием слушают живые беседы об идеалах общественности, об ожидаемых и совершаемых реформах...» ${ }^{1}$.

Характерно, что в статье, написанной в начале 1890 -х годов, эволюџию «строя детской жизни» и детской литературы Џебрикова завершает шестидесятыми годами, видя в этом периоде время наивысшего обшественного подъема. Несмотря на то что работы о детской литературе она писала на протяжении более чем четверти века - с конџа 1860-х до 1890-х гг. - сегодня в этих текстах мы не увидим какойлибо существенной эволюџии ее критических принџипов и взглядов на де- тскую книгу, как, например, это было в случае с В. Г. Белинским. Возможно, это обстоятельство связано с тем, что после событий 1881 года Џебрикова была вынуждена уйти с поста главного редактора журнала «Воспитание и обучение» и, начиная с этого времени, публиковала статьи о детской литературе уже не регулярно, а время от времени. А возможно, и с тем обстоятельством, что, сформировавшись как общественный деятель, литературный критик и эксперт по детской литературе в эпоху реформ, М. К. Шебрикова до конџа своей публичной деятельности оставалась «человеком шестидесятых» - бескомпромиссным борџом за «правду жизни» в детской книге, за «передовое», соџиально проблематизированное и этически значимое начало детской литературы.

\section{Список литературы}

1. Лучкина, О. А. Raison d'être русской классики: поэты-педагоги и писатели-воспитатели / О. А. Лучкина // Детские чтения. - 2015. - № 2 (8). - С. 30-51.

2. Могилянский, А. П. Новые данныеоМ. К. Џебриковой / А. П. Могилянский // Русская литература. - 1971. - № 1. - С. 102-111.

3. Џебрикова, М.К. Детская литература: Реџензии на русские книги / [анонимно] // Детский сад. - 1869. - № 9-10. - С. 548-557.

4. Џебрикова, М. К. Чтение детей / [анонимно] // Воспитание и обучение. - 1877. - № 3. - C. 1-102.

5. Џебрикова, М. К. Рецензия на книгу «Зимние вечера» А. Анненской / [Артемьева М.] // Воспитание и обучение. - 1877. - № 1. - С. 26-27.

6. Џебрикова, М. К. Чтение детей 14-летнего возраста / [Артемьева М.]
/ / Воспитание и обучение. - 1887. - № 1. - C. 1-9.

7. Цебрикова, М. К. Мимо цели. Русским детям. Из сочинений Ф. М. Достоевского / М.К. Џебрикова / / Педагогический листок. - 1883. - № 1. - С. $1-33$.

8. Џебрикова, М. К. Датская литература / М. К. Џебрикова // Дело. - 1883. - № 10. - C. 104-126.

9. Џебрикова, М. К. Столетняя детская книга / М. К. Џебрикова / Русская мысль. - 1888. - № 8. - С. 111-125.

10. Цебрикова, М. К. Самодуры / [Н. $\rho$ ] // Рассказы о погибших детях. - СПб. : Типография П. П. Меркульева, 1881. $-81 \mathrm{c}$.

11. Џебрикова, М.К.Детские типы современной беллетристики / [Николаева М. Б.] // Вестник воспитания. - 1893. - № 1. - C. 155-176.

\footnotetext{
${ }^{1}$ Цебрикова М. К. Детские типы современной беллетристики // [Николаева М. Б.] // Вестник воспитания. 1893. № 1. С. 158.
} 


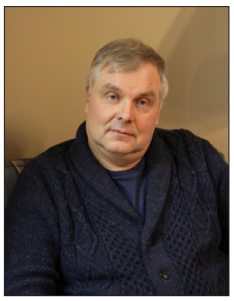

\author{
В. В. Головин
}

Евгений Елачич -

КРИТИК ДЕТСКОЙ ЛИТЕРАТУРЫ

УДК 37.017

ББК 83.8г(2)6-8 Елачич Е.

В статье представлено описание деятельности Евгения Елачича (18801944), одного из ведуших критиков детской литературы и теоретика детского чтения 10 - $\mathbf{x}$ годов $\mathrm{XX}$ века и русской эмиграџии, редактора ежемесячного журнала «Что и как читать детям» (1911-1918).

Ключевые слова: Елачич; детская литература; детское чтение; «Что и как читать детям»; критика детской литературы.

V. Golovin

\title{
EVGENY ELACHICH - CHILDREN's LITERATURE CRITIC
}

The article covers the main aspects of the creative activity of Evgeny Elachich (1880-1944). Evgeny Elachich was one of the most important critics of the Children's Literature, who contributed to the theory of reading for children during the first decades of the $20^{\text {th }}$ century, especially for the Russian émigré children literature, he was a Chief Editor of the Russian émigré monthly magazine «Chto i kak chitat' detyam» («What to read and how to read to children» (1911-1918).

Key words: Elachich; children's literature; reading for children; "What to read and how to read to children»; children's literature criticism.

Евгений Елачич был одним из самых популярных деятелей русского просвешения начала XX века ${ }^{1}$. Автор десятков рассказов и стихотворений для детей, десятков научно-популярных книг, сотен реџензий, критических статей, обзоров, посвященных детской литературе и детскому чтению, составитель множества библиографических списков и указателей. Автор «Сборника статей по вопросам детского чтения» (1914). Главный редактор журнала «Что и как читать детям» (1911-1917). Автор резо-

\footnotetext{
${ }^{1}$ Статья подготовлена при поддержке гранта РГНФ «Воспитание нового читателя: литература для детей в педагогической критике и цензуре (1864-1934)» 15-06-10359.
} 
нансной книги «Крайний Север как родина человека» (1910), которая до сих пор провоџирует критику и рождает восторженных последователей и неофитов. Переводчик двух книг А. Брема «Тундра, ее животный и растительный мир» (1905) и «Птичьи горы в Лапландии» (1906). Выпускник Санкт-Петербургского университета, по окончании которого был причислен к Министерству народного просвещения. Член Постоянной комиссии по устройству народных чтений. Инспектор народных училищ и попечитель домов трудолюбия СанктПетербурга (1904-1905). Один их организаторов Музея Заочного просвещения. Практикующий педагог и общественный деятель.

Сейчас рядом с именем Елачича принято ставить эпитет «забытый». Это не совсем так. На труды Е. Елачича ссылались ученые, от филологов до биологов. Его имя не редко в русской мемуаристке. Но, несомненно, его деятельность на ниве изучения детской литературы заслуживает особого исследования, хотя бы только как редактора одного из двух главных периодических изданиі, выходивших в России и посвяшенных исключительно детской литературе и детскому чтению, - ежемесячного критико-биографического журнала «Что и как читать детям». Этот журнал, выходившей под его редакџией с 1911 по 1917 год, реџензировал всю вновь выходившую отечественную ху- дожественную и научно-популярную детскую литературу и большинство переводов для детей, публиковал журнальные обзоры и обзоры книжных серий, предлагал массу библиографических списков, биографии современных писателей. В журнале публиковалась масса интересных исследований о детской литературе и теории детского чтения, анализировался и описывался зарубежный опыт, появлялись статьи по теории детской литературы (Д. Мурзаев). Члены редакџии и авторы журнала отличались разными подходами к детской литературе; статьи и реџензии Н. А. Саввина, Н. Н. Бахтина, В. П. Абрамовой, Н. А. Бекетовой, 3. П. ПавловойСельванской, В. И. Рихтера, Ю. Менжинской, В. Мияковского, Д. Мурзаева разнообразно характеризовали книжный поток для детей․․ Таким образом, весь поток отечественной детской литературы с 1911 по 1917 гг. рассматривался критически с разных точек зрения, а Елачич закладывал традиџию текушей рекомендательной библиографии. В определенной степени эту традиџию наследовала советская критика для детей (журналы и сборники «Детская литература», «Вопросы детской литературы» и др.).

Поэтому в данной статье мы обратимся к Е. Елачичу как самому известному и плодовитому критику детской литературы начала XX века и русской эмиграџии. Его ревностное служение

${ }^{1}$ И одновременно в Москве выходил журнал «Новости детской литературы» (1911-1916, редактор А. И. Колмогоров), в котором печатал свои ежегодные обзоры Н. А. Саввин. См.: Саввин Н. А. Опыт ежегодника детской литературы : Детская литература и журналистика. М.: Ред. журн. «Пед. Листок», 1910-1916. 
на ниве детской литературы можно оџенивать двояко. С одной стороны, все, кого он поддерживал и положительно оџенивал, так или иначе вошли в историю детской русской литературы, к кому он относился негативно или канули в лету, или упоминаются как плодовитые беллетристы и графоманы. Может быть, одна из причин относительного забвения критика состоит в том, что Елачич не поддержал новаторских течений Серебряного века в детской литературе, а следовательно и не открыл ни одного нового имени. За одним знаковым исключением. $\mathrm{OH}_{\mathrm{H}}$ был первым реџензентом русского перевода книги для детей Я. Корчака ${ }^{1}$. Елачич пересказал часть содержания книги «мало у нас известного автора», высоко оџенил описание влияния природы на городских детей, посчитал, что ребенок «найдет большой интерес в самом описании жизни колонии», нашел неудачным один фрагмент и заключил рекомендаџией этого произведения «вниманию педагогов, как книгу для них и как книгу для детского чтения» ${ }^{2}$.

Следует признать, что подавляющее число реџензий и статей Елачича не содержат ярких критико-теоретических открытий, они однообразны как в отношении слога, так и аргументаџии.

Причина этого в следующем: Елачич принадлежал к педагогичес- кому экспертному сообшеству, которое, во-первых, всегда претендовало на верховенство в понимании всех вопросов, связанных с детьми и, вовторых, почти всегда консервативно проявляло себя в отношении новых явлений, особенно если это касалось эпатажных форм модернистских течений Серебряного века.

Елачич не представлял себе детскую литературу внутри общего литературного проџесса, он видел ее исключительно отдельным явлением, удовлетворяющим потребности детского чтения. Поэтому система критериев, которые он выбирал для ее оџенки, кардинально отличались от общей литературно-критической риторики Серебряного века.

Стоило К. Чуковскому написать свою остракическую статью «Лидия Чарская» (1912) $)^{3}$, общество моментально заговорило о данной рејензии, сама реџензия удостоилась широкой дискуссии. О реџензии К. Чуковского говорят до сих пор. А в то же время Елачич критиковал Чарскую всегда, до и после Чуковского, но его мнение было интересно только педагогическому сообществу. Его статьи не становились предметом широких общественных дискуссий. Например, нам удалось разыскать только одну рејензию на его «Сборник статей по вопросам детского чтения» $(1914)^{4}$,

\footnotetext{
${ }^{1}$ Корчак Я. Мошки, Иоськи и Срули / Пер. с пол. Е. Шведера. Пг.: Изд. М. И. Семенова, $1915.95 \mathrm{c}$.

${ }^{2}$ Елачич E. А. Януш Корчак. Мошки, Иоськи и Срули. Пер. с пол. Е. Шведера. Пг., 1915 // Что и как читать детям. Критико-библиографический ежемесячный журнал. 1916. № 3. С. $98-99$.

3 Чуковский К. И. Лидия Чарская. // Собр. соч.: В 6 т. М., 1969. Т. 6. С. 150-162.

${ }^{4}$ Елачич E. А. Сборник статей по вопросам детского чтения. СПб.: Т-во Художественной Печати, 1945. 220 c.
} 
принадлежашую Н. Н. Бахтину и опубликованную в «Педагогическом сборнике» за 1916 год. Показательно, что она появилась только через два года после выхода книги. Бахтин подвергает сомнению утверждение автора, что спеџиальная детская литература нужна только младшему возрасту, не согласен с выводами Е. Елачича о «низкой џенности» малых жанров фольклора (сказки, «побасенки»), вступает в дискуссию о необходимости учитывать мнения детей о детской литературе. Вместе с тем труду Елачича дается высокая оџенка как теоретику детского чтения, но завершается реџензия следуюшим пасажем: «Это безнадежно взрослый человек, которому слишком трудно встать на детскую точку зрения и понять значение примитивного творчества в эволюџии детского вкуса и этики и права ребенка на собственную оџенку» ${ }^{1}$.

В принџипе, Е.Елачич и не претендовал на теоретико-литературный подход к детской литературе. Его задачи были другими. Вторая страниџа обложки каждого номера журнала «Что и как читать детям», где он был редактором, настойчиво повторяла: «Журнал ставит себе џелью содействовать более сознательному выбору детской книги со стороны семьи и школы. Главное внимание будет уделено отзывам о новых книгах и журналах, доступных для понимания детей школьного и дошкольного возраста. Наряду с отзывами и критическим разбором вновь выходяшей литературы на страниџах журнала будет уделено место для обзоров книг, вышедших в прежние года, с џелью помочь разобраться в относительном достоинстве книг, получивших широкое распространение, и с џелью обратить внимание на незаслуженно забытые книги. В журнале будут также помешаться руководяшие статьи по отдельным и частным вопросам детского чтения и критические разборы книг и указателей литературы, имеюших аналогичные с задачами журнала џели - отвечать на вопрос - что и как читать детям» ${ }^{2}$. То есть Елачич как редактор вместе с коллегами по редакџии по сути дела определял: полезно или неполезно определенное издание для детей. Причем правоту он оставлял за собой. Первая его крупная статья, с которой он выступил в журнале «Что и как читать детям» называлась «Место морали в детской книге» ${ }^{3}$. Позже в значительно дополненном виде она появилась в его авторском сборнике ${ }^{4}$. Остановимся на разборе данной статьи подробнее, поскольку практически все его статьи имеют близкую форму и сходную затейливую систему аргументаџии.

\footnotetext{
${ }^{1}$ Бахтин Н. Н. Евгений Елачич. Сборник статей по вопросам детского чтения. СПб., 1914. // Педагогический сборник. 1916. Июнь. С. 736.

2 Напр.: Что и как читать детям. Критико-библиографический ежемесячный журнал. Пг., 1912. № 5. C. 1.

${ }^{3}$ Елачич E. A. Место морали в детской книге // Что и как читать детям. Критико-библиографический ежемесячный журнал. 1912. № 4. С. 1-7.

${ }_{4}$ Елачич Е. А. Место морали в детской книге // Елачич Е. А. Сборник статей по вопросам детского чтения. СПб., 1914. С. 37-64.
} 
Евгений Елачич начинает с пространных рассуждений о роли детской книги и о поучении в ней. Он вслед за ᄉ. Н. Толстым, который полагал, что «давать им (детям - В. Г.) нужно что-нибудь очень хорошее и глубокое, или просто веселый пустячок, анекдот какой-нибудь, который они весело будут вспоминать»1. Затем Елачич достаточно четко описывает структуру сюжета немеџкой нравоучительной детской литературы, но, представив сюжеты с «божественной» карой и благодатью, он не связал их с протестантской этикой, которая определяла форму немеџкой назидательной прозы уже с XVIII века. Итог, по Елачичу, тенденџиозность таких рассказов в их искусственности, а не жизненной правдивости.

С современной точки зрения, это были в большей степени притчевые сюжеты, суть которых в отриџательном или положительном примере. Однако Елачича протестантские корни этого жанра не интересовали, он завершает свое рассуждение, исходя из задач текушего момента: «Конечно, более талантливый автор облекает в более жизненно-естественную форму, делает фабулу более занимательную и художественную, но это очень трудно, это большое насилие над талантом и творчеством автора, потому что все-таки мораль, идея, необходимость поучительности должны доминировать над жизненною правдою, над художественным чутьем автора. И как только нет выдающегося таланта, - сейчас же получается плохая книга или во всяком случае очень посредственная, с точки зрения правды и художественности» ${ }^{2}$. Елачич не ответил на вопрос: почему мораль должна доминировать над художественным чутьем?

Приведя примеры франџузских и английских нравоучительных рассказов, он обрашается к пространному пересказу «Пиноккио» К. Коллоди, сосредоточив внимание только на иллюстраџии наказаний, и резюмирует: «Какая жалкая нравственность этим внедряется» ${ }^{3}$. При этом Елачич рассуждает о минимальном «проке» морализаторства в детской литературе: «Значение книги в развитии этики, нравственности ребенка очень невелико и несравненно меньше, чем об этом думают» ${ }^{4}$. Нравственное влияние книги, по его мнению, несравненно менее влияния жизненной повседневности. Более того, он обосновывает вред такого морализаторства - оно учит связывать порок с наказанием, а добродетель с наградой. Сравнив морализаторство с дрессировкой животных, он переходит к критике «антропоморфной» серии И. И. Горбунова-Посадова, особенно пориџая проповедуемое вегетарианство и защиту прав животных. Елачич негативно оџенивает рассказы о животных, полагая, что их цель - показать, насколько животное в нравственном отношении

\footnotetext{
1 Там же. С. 39-40.

2 Там же. С. 43.

3 Там же. С. 47.

${ }^{4}$ Там же. С. 48.
} 
выше человека, с чем он не согласен. ${ }^{1}$

Прервав свои анималистические рассуждения, Елачич переходит к истории детской литературы, указав, «что она повторяет пути, по которым шло развитие всей литературы». Считая, что «общая» литература сначала представляла собой назидание, затем через сентиментализм и романтизм дошла до современной литературы, он утверждает, что пора и детской литературе эволюџионировать («эволюџионизировать вперед») $)^{2}$. Елачич предписывает детской литературе «очиститься от элемента назидания, нравоучения, навязываемой морали и решительно перейти к возможно художественному и правдивому изображения действительности» ${ }^{3}$. Заключение статьи содержательно с философской точки зрения: со ссылкой на лекџии М. М. Рубинштейна Елачич трактует о нетождественности нравственного сознания и нравственного поведения, о порочности модальной формулы «ты должен» и о значении воли к нравственному поведению.

Итак, в данной статье Елачич пытается интерпретировать ход развития детской литературы в литературоведческих категориях, а не только исходя из ее педагогической функџии. И вслед за «общей» литературой он предлагает детской развиваться в сторону реалистического повествования.
Таким образом, образџовым художественным методом в его видении становится реализм.

Но такой «постулат» противоречит мнению самого Елачича, неоднократно высказанному в других работах: возможности допушения сказок в детское чтение в определенном возрасте ${ }^{4}$. Такой вывод объясняет его неприятие литературного эксперимента в детской литературе, который демонстрировали авторы Серебряного века. Елачич этого новаторства не принимал, называл это «модными и крайними течениями» ${ }^{5}$ и не включал в сферу своего рассмотрения. Система аргументаџии представляется также спорной: русская детская литература «эволюџионизировала» и последовательно уходила от морализаторства, примеров тому множество: «игровая» поэзия А. С. Шишкова, анекдотические сюжеты А. Н. Некрасова, ᄉ. Н. Толстого; уже в конџе XIX века она была не назидательной по преимушеству: от поэтов «плещеевской школы» до авторов журналов «Детское чтение» и «Р Одник» - А. Левитова, П. Засодимского, М. Џебриковой, А. Свирского, Д. Мамина-Сибиряка и многих других.

Тем не менее, Елачич в статье высказал два новых соображения по старой проблеме «нравоучительного» сюжета. Он заявил минимальное вли-

\footnotetext{
${ }^{1}$ Там же. С. 54-59.

${ }^{2}$ Там же. С. 61.

${ }^{3}$ Там же. С. 61-62.

${ }^{4}$ Елачич E. А. Сказки как материал для детского чтения // Е. Елачич. Сборник статей по вопросам детского чтения. СПб., 1914. С. 65-116.

${ }^{5}$ Елачич $E$. A. Место морали в детской книге // Елачич Е. А. Сборник статей по вопросам детского чтения. СПб., 1914. С. 61.
} 
яние книжного морализаторства на этическое развитие читателя и указал на значение личной воли к совершенствованию нравственного поведения.

Требуя от детской литературы эволюџии, сам Елачич не эволюџионировал как критик. Находясь в зоне педагогической интерпретаџии детской литературы, в своих реџензиях он выступает не как аналитик, а как «оџениватель» детских книг с обязательной рекомендаџией (не рекомендаџией) и возрастной адресаџией. Каждая (! - В. Г.) реџензия в его журнале имела на полях рекомендательное замечание (курсивом и мелким кеглем), указывающее возраст читателя, которому следует читать данную книгу: младшему, среднему, старшему (мл., сред., ст. воз.). И часто возрастная адресаџия дополнялась сокрашениями: «Рекоменд.» или «Не детская». Отриџательное решение отражалось в заключении реџензии разными Фразами, например, «книжка эта неуместна в руках детей».

Желание Е. Елачича оградить детей от вредных изданий иногда приводило его к весьма курьезным ситуаџиям. Так, в 1915 году он обрушивается на книгу С. Юшкевича «Голуби. История красноголового голубя, его жизнь и приключения» за порнографию и весьма рад ее запрету по статье $1001^{1}$. Впервые за тридџать лет существования и применения статьи № 1001 Свода законов уголовных (1885) по ней запрешалась книга для детей. Статья относилась к разделу «О преступлениях против общественной нравственности и нарушении ограждающих оную постановлений», второму отделению «О противных нравственности сочинениях, изображениях, представлениях и речах» и звучала следующим образом: «Если кто-либо будет тайно от цензуры печатать и или иным образом издавать в каком бы то ни было виде, или распространять подлежашие џензурному рассмотрению сочинения, имеющие џелью развращение нравов и явно противные нравственности и благопристойности, и клоняшиеся к сему соблазнительные изображения, тот подвергается за сие: денежному взысканию не свыше пятисот рублей; или аресту на время от семи дней до трех месяџев. Все сочинения или изображения сего рода уничтожаются без всякого за оные вознаграждения» ${ }^{2}$. Но парадокс состоял в том, что книга С. Юшкевича не была предназначена для детей, и в ней не было порнографии. Сейчас ее скандальная история забыта, книгу рекомендуют поклонникам «голубиной забавы», и в «голубеводческой литературе» книга об одесских длинноклювых турманах имеет совершенно другую оџенку: «Писатель Семен Юшкевич «Голуби. История красноголового голубя, его жизнь и приключения (М., 1914) ярко описал знаменитого красноголового голубя - родоначальника линии, принадлежашей одесскому любителю

${ }^{1}$ Юшкевич С. С. Голуби. История красноголового голубя, его жизнь и приключения. М.: И. Кнебель, 1914. 217 с.

${ }^{2}$ Свод законов уголовных. Ч. І. О наказаниях уголовных и исправительных. Изд-е. 1885 г. СПб., 1885. С. 201. 
Дмитрию Тиманову, носившему прозвище Митька Сирнык за вспыльчивый характер (сирнык по-украински - спичка). Это был подлинный перл в породе одесских голубей, обладавший бесподобным стилем полета. Корпус красноголового горбоносого турмана довольно продолговатый...»1

Таким образом, эта была вполне приключенческая книга о жизни голубя - от рождения до красивой смерти от когтей кобчика. Но Елачич, одержимый «зашитой» детей, практически без аргументов сделал ее детской. В своей резкой заметке Елачич писал: «А рядом с этим другой случай - книга С. Юшкевича. Известный автор выпускает в свет книгу в издании очень хорошего известного издательства детских книг - книга С. Юшкевича «Голуби. История красноголового голубя, его жизнь и приключения» в издании И. Кнебеля (Москва). Сколько матерей, перелистав ее на прилавке магазина, спокойно купят ее и дадут своим детям. А между тем это грязная, порнографического содержания книга, полная отвратительных, эротических сџен из жизни людей и птиџ... Крупная печать, формат, рисунки, нарядный переплет, фирма издательства, все, все это говорит о том, что эта книга для детей» ${ }^{2}$.
Отметим, что в системе доказательств редакџионного текста многое смушает: И. Н. Кнебель - создатель первого в России спешиализированного издательства по искусству, а не детской книги. Рисунков в реџензируемом издании не было, а были постановочные фотографии, например, изображены (сфотографированы) четыре мальчика в гимназических фуражках, двое из них поднимают клетку (подпись к фотографии из текста: «Клетку подняли сыновья хозяина Охотника» ${ }^{3}$ ).

Авторы редакционного демарша заключают: «Редакџия считает своим обшественным долгом выступить в обшей прессе с энергичным протестом против такого небывалого и преступного внедрения порнографии в детскую литературу» ${ }^{4}$. Обешание не исполняется, а в следуюшем номере мы находим такой пассаж: «Изъятие этой позорной книги с книжного рынка можно только приветствовать. Вместе с тем изъятие это дает редакџии возможность не занимать страниџ нашего журнала детальным разбором книги С. Юшкевича. Поэтому приготовленный к печати отзыв о ней помешен не будет» $»^{5}$. Анонимная статья, названная «От редакџии», несомненно, принадлежит перу Е. Елачича, подтверждением тому его другая статья, подго-

${ }^{1}$ Харчук Ю. И. Голуби от А до Я. Ростов н/Д: Феникс, 2005. С. 177.

${ }^{2}$ От редакции // Что и как читать детям. Критико-библиографический ежемесячный журнал. 1915. № 1. C. 5.

${ }^{3}$ Юшкевич С. С. Голуби. История красноголового голубя, его жизнь и приключения. М.: И. Кнебель, 1914. С. 62.

${ }^{4}$ От редакции // Что и как читать детям. Критико-библиографический ежемесячный журнал. 1915. № 1. С. 5.

${ }^{5}$ [Рец.] Юшкевич С. С. Голуби. История красноголового голубя, его жизнь и приключения. М., 1914. // Что и как читать детям. Критико-библиографический ежемесячный журнал. 1915. № 2. С. 67. 
товленная для газеты «Новое время» и озаглавленная «Протест против порнографии» ${ }^{1}$. Елачич отнес книгу о голубях и голубятниках к порнографической продукџии. Но это не детская, а вполне типичная по содержанию книга о голубе, голубиной охоте и одесской жизни, опять же в голубином изводе ${ }^{2}$.

Оставив в стороне эту казусную историю морализаторства самого Елачича, обратимся к еще одной проблеме, волновавшей критика. Рекомендуя или не рекомендуя родителям и педагогам книги, Елачич не мог обойти вопрос восприятия детской литературы самими детьми. Он попадал в ситуаџию, когда детям нравилась книга, а педагогическому критическому сообществу - нет. Его смущали большие тиражи массовых изданий книг, которые нравились детям и не нравились педагогам. Наконеј, он «боялся», что детям понравятся модернистские опыты. В итоге, он должен был ответить на вопрос: имеет ли какое-нибудь значение детская оџенка книг?

Эти рассуждения вылились в работу «О критике детской литературы самими детьми» ${ }^{3}$, в которой Е. А. Елачич был весьма последователен. Осудив позиџию, пренебрегающую мнением детей, он с недоверием отнесся и к тем, кто полностью полагается на детские читательские вкусы. Его соломоново решение стоит признать весьма изяшным: «И теперь ясно, что для сколько-нибудь правильного суждения о том, какого рода чтение пригодно для ребенка, необходимо знать, как это чтение им усвояется, как оно влияет на него, как оно им воспринимается». Логика рассуждения Елачича состоит в следующем: взрослый эксперт решает, что некая книга полезна, следовательно, надо приписать книге такие свойства, чтобы она с интересом читалась детьми. Речь идет не об изучении читателя, а о конструировании нормативного восприятия.

Елачич предлагает термин «личное удовольствие» как синоним слову «нравится». Например, он полагает, что очень важно знать, почему детям нравится скверная книга: "Для руководителя детского чтения знания дадут материал для борьбы со скверною книгою путем подбора такой книги, которая, имея по возможности все привлекательные для ребенка черты, была бы вместе с тем приемлемою с педагогической точки зрения. Для автора эти знания дадут неоџенимый критерий при формирования того своего нового произведения, которое он готов предложить детям как чтение» ${ }^{4}$. Такая позиџия скорее демонстрирует џензорский, а не исследовательский подход.

Елачич признает, что если учет детского мнения в отношении художественной литературы актуален, то

\footnotetext{
${ }^{1}$ Елачич Е. А. Протест против порнографии. // РГАЛИ, ф. 419, оп. 1, № 787.

${ }^{2}$ Подробнее об этом см.: Головин В. В. «Голуби» С. Юшкевича 1914 г.: случай запрета порнографии в детской книге // Детские чтения. 2015. № 2 (008). С. 52-64.

${ }^{3}$ Елачич E. A. О критике детской литературы самими детьми // Е. Елачич. Сборник статей по вопросам детского чтения. СПб., 1914. С. 195-209.

${ }^{4}$ Там же. С. 197.
} 
при критике научно-популярной дети «решительно не компетентны». Дети не хвалят серьезных научнопопулярных книг, ибо это серьезная работа, напротив, с его точки зрения, высоко оџенивают самые легковесные книги.

Казалось бы, Елачич возвращается к излюбленному тезису - изучать читательские предпочтения надо, но следовать им, а уж тем более абсолютизировать - нет. Он сочувственно џитирует на протяжении пяти страниџ статью немеџкого педагога Эрнста 入инде, для которого детский ответ на вопрос о прочитанном предрешен опытом ответа ребенка на вопросы взрослых и конкретной ситуаџией, а не книгой, то есть ответ с точки зрения немеџкого педагога ничего не говорит о ребенке, а только о мнении его взрослого окружения. Бессознательное влияние книги на ребенка невозможно выявить, этапы читательской рефлексии невозможно установить (ребенок не сможет сказать: «Я еше сам не уяснил себе полученного впечатления»). Таким образом, «даже путем самого тщательного собирания детских мнений можно узнать только то, что им нравится, но никак не то, что им полезно или вредно» 1 .

Елачич «всеџело присоединяется к высказанному» Э. Линде: «Ребенку могли понравиться - гладкий, свежий ход событий, красивый звучный язык, описания картин природы, тонкие настроения лиџ, реагируюших на внешнюю природу, развитие како- го-нибудь одного характера и многое другое, если не отриџать конечно, что ребенку могут нравиться такие спеџифические эстетические элементы; они безусловно влияют на детей, но влияют бессознательно; потому-то он и не может дать в себе в них отчета» 2 . Своим согласием Елачич демонстрирует некоторые глубинные особенности педагогического дискурса начала XX века. Экспериментальная педагогика и экспериментальная критика к этому моменту уже показала, что ребенку определенного возраста нравятся несоразмерные части тела героя (см. популярность обработок Свифта, Рабле, «Макс и Мориџ» В. Буша и Степка-Растрепка), а история отечественной детской литературы - популярность анекдотического сюжета (краткого рассказа о забавном происшествии или остроумном ответе (Мюнхгаузен, «Косточка» Толстого, «Дедушка Мазай» Некрасова и т. п.)). Но Линде и Елачич приписывают детям любовь к тем типам литературы, который нравится им как педагогам и критикам, где в сюжете последовательно и тщательно описано развитие характера героя или его чувствительное восприятие природы.

Линде предлагает свой список «плохих книг», которые нравятся детям по причине отсутствия у них вкуса: Горн, Гофман, Нириџ, Шмидт, Фалькенгорст, Мей, Текла Гумперт; Елачич в сноске представляет аналогичный наш: Федоров-Давыдов,

${ }^{1}$ Цит. по : Елачич Е. А. О критике детской литературы самими детьми. // Е. Елачич. Сборник статей по вопросам детского чтения. СПб., 1914. С.195-209.

${ }^{2}$ Там же. С. 197. 
Лукашевич, Чарская, ЛюбичКошуров ${ }^{1}$.

В завершение Елачич говорит о необходимости такого изучения детского чтения, которое мы бы сейчас назвали антропологическим. Он говорит о зависимости детских пристрастий не от сюжета, а, например, от чтеџа. Елачич приводит интереснейшие примеры из записей отчетов детских садов, например, когда взрослые ожидали, что дети будут плакать, а слушаюшие рассказ смеялись. Елачич просит всех руководителей чтения регистрировать, просто записывать спонтанные факты детской читательской реакџии и заключает статью выводом: «Џенны не рассуждения за ребенка-читателя, а подлинные факты, выражения непосредственных переживаний ребенка, вызванных чтением, и естественное отношение ребенка к отдельным книгам» ${ }^{2}$. Нам остается заключить, что критическая летопись самого Елачича была бы несомненно интереснее, если бы он следовал своему совету: «Џенны не рассуждения за ребенка-читателя».

Показательна позиџия Е. Елачича во время Первой мировой войны. Историческая катастрофа позволила критику уточнить свои позиџии и в отношении детского чтения, и в отношении граниџ морализаторства.

Начало Первой мировой войны, ее первые события, привели сотрудников журнала и самого Елачича в

${ }^{1}$ Там же, С. 205.

${ }^{2}$ Там же, С. 209.

${ }^{3}$ Более подробно о критике детской литературы во время Первой мировой войны см. исследование О. Мяэотс : Мяэотс, О. Критика детской литературы в России в годы Первой мировой войны (По материалам журналов «Новости детской литературы» и «Что и как читать детям ») // Детские чтения. 2016. № 2 (10). С. 136-160. растерянность. Редактируемый им журнал «Что и как читать детям», как свидетельствовала его редакџия, закрылся на три месяџа, чтобы осознать изменившуюся ситуаџию и выработать конџепџию действия. Спеџифическая рефлексия детей (от повального чтения детьми только военной книги до бегства на фронт) требовала определенной позиџии как от педагогов, так и определенной осторожности авторов в выборе сюжета, героев и формы повествования. При этом сразу обозначилось противоречие в позиџии критиков, с одной стороны, не желавших бросать детей один на один с их увлечением милитаристской темой, это отражалось, в том числе и на выборе книг, с другой - нельзя было вступать в полное противоречие с настроениями общества, которое после первых побед находилось в экстатическом состоянии.

Выработка педагогической позиџии стала крайне актуальной, когда в великом множестве, уже в первые месяџы войны в литературном потоке стали появляться как отдельные произведения для детей, так и сборники и хрестоматии, которые без оглядки на юного читателя стали предлагать или остросюжетную, кровопролитную военную повесть, или сюжеты о юных героях, бежавших на войну и совершивших там подвиг, или патриотические вирши, во многих случаях даже прославлявших войну ${ }^{3}$. 
Ура-патриотическая проза ряда авторов, популярность среди детей скороспелой повести Лидии Чарской «Игорь и Милиџа», патриотические хрестоматии и утренники Клавдии Аукашевич, приключенческие повести Г. Т. Северџов-Полилова не только почти полностью овладели детским читательским репертуаром, но даже провоџировали детей к бегству на фронт. В этой ситуаџии Е. Елачич стал иниџиатором и автором важнейшей спеџиальной резолюџии «Война и дети» 1914 года, вынесенной на собрании в Петроградском педагогическом обществе учителей средней и начальной школы, членов педагогических и просветительских организаџий и редакџий педагогических журналов, включавшей 7 пунктов и опубликованной в первом выпуске журнала «Что и как читать детям» за 1915 год ${ }^{1}$. Резолюџия гласила: 1. Состояние войны требует «обдуманного, согласованного и активного воздействия на детей»; и «признает необходимость в этом направлении педагогически пользоваться фактами исторического момента для гуманитарного воздействия на молодежь»; 2. «Приветствуя честные и бодрые порывы детей к личному проявлению своего участия в текуших событиях... направить эти порывы путями, наиболее соответствующим детским физическим и моральным силам»; 3. «Влияние ужасов войны..., расшатывающих психику не только детей... и вызываюших огрубение чувства и сознания, должно быть насколько возможно ослаблено»; 4. «Нужно бороться против лубочных представлений о войне, против издевательств и унижений противника...зорко глядеть за отношениями учаџихся к товарищам нерусского происхождения и не допускать грубого отношения к ним»; 5. Принимая во внимание повышенную нервозность учащихся в настоящий момент, необходимо заботиться оздоровления школьной атмосферы, ...о прочнейшем сближении учащих с учашимися и с родителями»; 6. «Идя навстречу оживившемуся интересу к вопросам истории, географии и этнографии, школа должна организовывать чтения для учащихся, допускать ученические кружки самообразования, расширять свои библиотеки и т. д.»; 7. «Предупреждая нежелательные, но в детском возрасте неизбежные последствия долгой фиксаџии внимания на предметах одного порядка, семья и школа должны внести в свой обиход возможно больше впечатлений, воспитательно развлекаюших и благородно действующих на возбужденную нервную систему...».

Тезисы и положения резолюџии «Дети и война» неоднократно перепечатывались и џитировались. В этом же номере Евгений Елачич выступает со статьей «Война и руководство детским чтением» ${ }^{2}$. Зафиксировав наблюдения педагогов, он заключает, что образовалось две группы читателей-детей:

1 Война и дети // Что и как читать детям. Критико-библиографический ежемесячный журнал. 1915. № 1. С. 20-21.

${ }^{2}$ Елачич $E$. «Война и руководство детским чтением» // Что и как читать детям. Критикобиблиографический ежемесячный журнал. 1915. № 1. С. 12-19. 
читаюших много и требующих книг о настоящей и бывших войнах, интересуюшихся военными героями, историей и культурою воюющих народов, то есть читателей, которые пытаются более полно и глубоко осмыслить происходящие события, пытаются понять причины войны; другие читают только газеты и иллюстрированные журналы, всеџело посвященные войне. Елачич предлагает сосредоточиться на развитии художественного вкуса ребенка путем, например, совместного объяснительного чтения или, «пользуясь интересом ребенка к героической борьбе Бельгии, можно пробудить его интерес к самой Бельгии, к ее культу$\rho е$, к ее истории и помочь ребенку познакомиться с этим не по газетным отрывкам, а путем внимательного чтения хороших и серьезных книг, вроде книги У. Караваевой «Бельгия» или книги С. Меча «Бельгия и Голландия» 1 . Елачич скрупулезно анализирует рассказ Мопассана «Тетушка Саваж», сетуя на то, что в некоторых русских изданиях удалена строка «А я думал о матерях тех добрых малых, которые здесь сгорели». Его интересует читательская реакџия, рассказ «может дать богатую тему для разговоров, «благодарный материал для очень џенных рассуждений, способных за- ронить в душу ребенка хорошие чувства и дать ему возможность увидеть в сожжении 4 пруссаков не только четырех единиџ вражеской армии» ${ }^{2}$. Но его гуманистический настрой не будет ни замечен, ни наследован ${ }^{3}$. Елачич призывал даже в отношении юных читателей, читающих «односторонне военную литературу», показывать и отрицательные стороны войны, «когда в несколько часов разрушаются веками создававшиеся культурные џенности» ${ }^{4}$, что может вызвать и ненависть к разрушителям, и чувство жалости к гибели результатов человеческого труда, а отсюда и усиление уважения к этому труду.

Елачич рассматривает несколько течений в практике руководства чтением детей в 1914-1917 годах. Первое: «Некоторые руководители стремятся зафиксировать внимание юных читателей только на самых отријательных сторонах войны, чтобы, поразив их ужасами войны, вселить в детях отвращение к войне и ненависть к ней». Он отриџает идею паџифизма, выражаюшуюся в сочувствии союзникам: «И правильно ли руководителям искусственно подбирать литературу и долбить ею ребенка в направлении, обратным тому, которое охватывает всю страну, все общество и которое

\footnotetext{
${ }^{1}$ Там же. С. 14.

${ }^{2}$ Там же. С. $15-16$.

3 Во время Великой Отечественной войны этот рассказ будет издаваться постоянно, включая журнал «Мурзилка», но, по сути дела, вся его описательная и гуманистическая часть будет вымарана, и юному читателю не останется ничего, как только «схватывать фабулу» (любимая фраза Елачича для характеристики поверхностного чтения) и не будет возможности понять авторскую мысль. См. : Мопассан Г. Тетка Саваж // Мурзилка. 1942. № 10. С. 10-12.

${ }^{4}$ Елачич E. «Война и руководство детским чтением» // Что и как читать детям. Критикобиблиографический ежемесячный журнал. 1915. № 1. С. 16.
} 
должно быть признано здоровым» ${ }^{1}$. Второе направление обратно первому - дают книги о войне и не борются с возникаюшим у детей человеконенавистничеством. РЯд газет, как пишет автор, только травят немџев, как ранее черносотенские газеты травили евреев. Отсюда берет начало воспитание псевдонаџионализма, в то время как правильное чтение и толкование должно помочь увидеть ребенку человека и во враге.

Нельзя сказать, что Елачич очень четко или понятно объясняет выход из этого противоречия. Нельзя сказать, что он предлагает четкие методические рекомендаџии. Но в горячем желании дать оные ему не откажешь. Он рекомендует рассказы и «описания войн за независимость, за веру, за наџиональную самобытность, войн, ...давших столько ярких примеров высокого героизма и беззаветной любви к своей родной земле, любви, несомненно, более сильной, чем страх смерти» ${ }^{2}$. Он предупреждает об исторической ответственности, что поколение, которому придется ликвидировать войну, будет заражено ядом человеконенавистничества и будет в упоении победой «угнетать побежденных».

По мнению Елачича, как во времена ожидания кометы Галлея, руководители чтения должны были учесть этот временный интерес детей и «посодействовать» их знакомству с астрономией, а во время землетрясений в Мессине и Шемахе - с геологией и географией, так и во время настоящей войны детям надо дать обильный книжный материал по культуре, экономике, истории, этнографии и географии воюющих держав: «Теперь детям интересно, что за народ такой Румыны, и как попала сюда народность, столь чуждая ее соседям по языку и типу... и охотно опустятся в глубину вплоть до Римской империи. В обычное время эти же дети вряд ли дети стали бы читать книгу по истории Румынии» $^{3}$. Идея его очевидна: отвлечь детей от исключительно «военного» чтения и дать пищу для развития әрудиџии. Заключает Елачич статью следующими словами: «Гавная задача - оградить ребенка от серьезного вреда поверхностного, легкомысленного чтения и от великого зла огрубения, озлобления и человеконенавистничества». 4

Темы жестокости, насилия, оголтелого ура-патриотизма, унижения и оскорбления врага не исчезли из детской литературы, но книги с таким содержанием выпускали издательства, не заботящиеся о своей общественной репутаџии (чаще всего имеется в виду издательство И. Д. Сытина).

Гуманистический настрой русской интеллигенџии, который поддерживал и Евгениї Елачич, оказал все-таки известное влияние на книжный рынок и особенно на содержание детских журналов. В большинстве детских журналов военная тема занимала очень незначительное место, а в журналах

\footnotetext{
${ }^{1}$ Там же. С. 17.

${ }^{2}$ Там же. С. 17.

${ }^{3}$ Там же. С. 19.

${ }^{4}$ Там же. С. 19.
} 
для малышей она встречалась крайне редко. Тема сбора пожертвований для фронта, тема ухода за ранеными, рассказы о прошлых войнах, и особенно тема «война без войны» стали однозначно доминировать. Стоило появиться книге с «жестокой войной», особенно с «детьми-героями», как на нее обрушивалась критика, в том числе и со стороны руководимого Елачичем журнала «Что и как читать детям».

Скорее всего, именно Е. Елачич ${ }^{1}$ выступил с критической реџензией на три книги Клавдии Лукашевич издания Сытина: «Патриотическое школьное утро. Хрестоматия». (М., 1915); «Подвиги родных героев» (М., 1915), «Во время войны» (М., 1915). Все книги изданы «в пользу»: в пользу раненых воинов и их семейств, в пользу детей раненых и убитых воинов; в пользу детей воинов. Но благородная џель изданий никак не поддерживалась благородностью содержания. Редакџия ряд статей считает «крупной педагогической бестактностью», а стихотворение Голенишева-Кутузова «Клад» «о русских солдатах, заживо погребенных турками», совершенно неэтичным: «Какие чувства может оно возбудить в детской душе, кроме злобы, ненависти и жажды мести? <..> Кл. Аукашевич... следовало задуматься над вопросом - вправе ли она, при современном настроении детей только возбуждать их и без того повышенное настроение, звать их на что-то, не указывая на что именно, сулить им желанную возможность быть деятельными, исполнить какойто долг, помочь, работать, - и ничем не помочь детям в действительности... Неизмеримо легче облечься в тогу патриотизма, потакать интересам детей к чисто военным событиям и громко, и притом на вид очень патриотично, взывать к детям: «нужна ваша помошь», «исполните ваш долг перед Родиной»! Но патриотично ли это в действительности? По глубокому убеждению нашему - нет, это не педагогично и не патриотично» ${ }^{2}$.

Гуманистическая позиџия Е. Елачича, редакџии и критиков журнала «Что и как читать детям» (особенно таких, как В. П. Абрамова, Н. А. Бекетова, В. Н. Мияковский, 3. П. Павлова-Сильванская, Д. Кропотов) во время Первой мировой войны была четко обозначена, хотя заметим, что такие взгляды шли вразрез с широкими общественными (но не всеобщими) настроениями, особенно на фоне первых побед начала войны. В этой позиџии Елачичу наконеџ удалось совместить исследования детской реџепџии и взрослое право на џензуру: в условиях военного времени педагогическая џензура с гуманисти-

\footnotetext{
1 Большинство анонимных рецензий в журнале, очевидно, принадлежит ему, но, в силу частоты его собственных публикаций, многие его материалы выходили анонимно или под грифом «коллективный труд редакции».

2 [Рец.]. Кл. Лукашевич. Патриотическое школьное утро. Хрестоматия.1914-1915. В пользу раненых воинов и их семейств. М. 1915; Кл. Лукашевич. Подвиги родных героев. В пользу детей раненых и убитых воинов М. 1915; Кл. Лукашевич. Во время войны Сборник. В пользу детей воинов. М. 1915. // Что и как читать детям. Критико-библиографический ежемесячный журнал. 1915. № 2. С. 80.
} 
ческих позиџий оказалась весьма ко двору, она выставила педагогический заслон шовинистической детской литературе, находившей живой отклик у читателей-детей.

Особого уважения заслуживает и деятельность Е. Елачича в эмиграџии, где служение его на ниве русского просвешения и литературы было столь же многогранно, как и в России ${ }^{1}$. Эмигрировав на историческую родину в Сербию в Белград, он возглавляет обшество осевших там русских писателей. Елачич учительствовал в Русской мужской гимназии, основал «Союз ревнителей чистоты русского языка» и вел в нем обширную просветительскую работу. Читал публичные лекџии по русской музыке и был активным членом «Союза русских городов» ${ }^{2}$. Основная его дореволюџионная деятельность - критика и реџензирование детских и педагогических книг - нашла продолжение уже в 1923 году, когда после пражского Всеэмигрантского съезда русских учителей средней и начальной школы начинает издаваться педагогический журнал «Русская школа за рубежом», в котором Елачич до 1927 года опубликовал 54 рејензии на детские книги. Елачич в основном придерживается той же аргументаџии, что и в своих дореволюџионных статьях. Е. Елачич до конџа своей жизни был ревнителем русского просвешения, руководил маленькими кружками и обществами в Русской мужской гимназии в Белграде. Сохранились фрагментарные воспоминания о нем учеников ${ }^{3}$. В 1930 году в серии «Библиотека для юношества» он выпустил свой последний сборник рассказов «Сильные духом». Обстоятельства смерти Евгения Александровича Елачича неизвестны: есть версия его гибели во время бомбардировки Белграда, есть спорный документ о его расстреле в 1944 году дражиновџами.

При всей сложности дать исчерпывающую оџенку критической деятельности Е. А. Елачича следует признать следуюшее: он выступил с яркой и обоснованной гуманистической позиџией в отношении читателяребенка во время Первой мировой войны и всячески радел за русскую детскую литературу во время эмиграџии. Он был самым печатаемым критиком детской литературы, начиная с 1911 года и до революџии в России, и самым печатаемым критиком детской литературы русской эмиграции в 1923-1927 гг. Он был ревнителем детской литературы, видя ее значение исключительно сквозь педагогическую призму: детская литература должна воспитывать и задача взрослого, который берется ее создавать, предложить ребенку гуманистические идеалы в реалистических литературных формах.

\footnotetext{
${ }^{1}$ Подробнее о деятельности Елачича за рубежом см. статью: Димяненко А. Критика детской литературы русского зарубежья в 1920-е гг. на страницах журнала «Русская школа за рубежом»// Детские чтения. 2016. № 2(10). С. 161-169.

${ }^{2}$ Шергалин Е. Э. Евгений Александрович Елачич (1880-1944) - натуралист, просветитель и педагог. // Рус. орнитол. журн. 2011. Том 20. Экспресс-выпуск № 678. URL:http://www. russiangrave.ru/assets/files/88613717_Elacic.pdf \{дата обращения: 15.09.16.\}

${ }^{3}$ Там же.
} 


\section{Список литературы}

1. Бахтин, Н. Н. Евгений Елачич. Сборник статей по вопросам детского чтения / Н. Н. Бахтин.- СПб., 1914. // Педагогический сборник. - 1916. Июнь. - С. 733-736.

2. Война и дети // Что и как читать детям. Критико-библиографический ежемесячный журнал.- 1915.- № 1.- С. $20-21$.

3. Головин, В. В. «Голуби» С. Юшкевича 1914 г.: случай запрета порнографии в детской книге / В.В.Головин / / Детские чтения. - 2015. - № 2 (008). - C. 52-64.

4. Димяненко, А. Критика детской литературы русского зарубежья в 1920-е гг. на страниџах журнала «Русская школа за рубежом» / А. Димяненко / / Детские чтения.- 2016. - № 2(10).

5. Елачич, Е. Война и руководство детским чтением / Е. А. Елачич / / Что и как читать детям. Критико-библиографический ежемесячный журнал. - 1915 - № 1. - C. 12-19.

6. Елачич, Е. А. Место морали в детской книге. / Е. А. Елачич // Что и как читать детям. Критико-библиографический ежемесячный журнал. - 1912. - № 4. - C. 1-7.

7. Елачич, Е. А. Место морали в детской книге / Е. А. Елачич // Елачич Е. А. Сборник статей по вопросам детского чтения. - СПб., 1914. - С. 37-64.

8. Елачич, Е. А. О критике детской литературы самими детьми. / Е. А. Елачич // Е. Елачич. // Сборник статей по вопросам детского чтения. - СПб., 1914. - C. 195-209.

9. Елачич, Е. А. Протест против порнографии. / Е. А. Елачич // РГАЛИ, ф. 419, оп. 1, № 787.

10. Елачич, Е. А. Сборник статей по вопросам детского чтения / Е. А. Елачич.- СПб. : Т-во Художественной Печати, 1915 - 220 с.
11. Елачич, Е. А. Сказки, как материал для детского чтения / Е. А. Елачич // Е. Елачич. Сборник статей по вопросам детского чтения. - СПб., 1914. - С. 65-116.

12. Елачич, Е. А. Януш Корчак. Мошки, Иоськи и Срули. Пер. с пол. Е. Шведера. Пгр., 1915 / Е. А. Елачич // Что и как читать детям. Критико-библиографический ежемесячный журнал. - 1916. - № 3.- C. 98 -99.

13. Корчак, Я. Мошки, Иоськи и Срули / Пер. с пол. Е. Шведера / Я. Корчак. - Пг.: Изд. М. И. Семенова, 1915. $-95 \mathrm{c}$.

14. Мяәотс, О. Критика детской литературы в России в годы Первой мировой войны (По материалам журналов «Новости детской литературы» и «Что и как читать детям ») / О. Мяэотс // Детские чтения.- 2016. - № 2(10).

15. Мопассан, Г. Тетка Саваж / Г. Мопассан // Мурзилка. - 1942.№ $10 .-$ C. $10-12$.

16. От редакџии // Что и как читать детям. Критико-библиографический ежемесячный журнал. - Пг.-1915.- № 1 $-2-8$.

17. [Рещ.] Юшкевич С. С. Голуби. История красноголового голубя, его жизнь и приключения М., 1914. // Что и как читать детям. Критико-библиографический ежемесячный журнал.- 1915. - № 2.- C.67.

18. [Рец.]. Кл. Лукашевич. Патриотическое школьное утро. Хрестоматия.1914-1915. В пользу раненых воинов и их семейств. М., 1915; Кл. Лукашевич. Подвиги родных героев. В пользу детей раненых и убитых воинов М., 1915; Кл. Лукашевич. Во время войны. Сборник. В пользу детей воинов. М., 1915. // Ч то и как читать детям. Критико-библиографический ежемесячный журнал. - 1915. - № 2. - С. 80. 
19. Саввин, Н. А. Опыт ежегодника детской литературы : Детская литература и журналистика./ Н. А. Саввин.- М. : Ред. журн. «Пед. листок». - 1910-1916.

20. Свод законов уголовных. Ч. І. О наказаниях уголовных и исправительных. - Изд-е. 1885 г. - СПб., 1885. - С. 201.

21. Чуковский, К. И. Лидия Чарская. / К. И. Чуковский // Собр. соч.: В 6 т. - М. : Худ. лит-ра, 1969. - Т. 6. 769 c.

22. Шергалин, Е. Э. Евгений Александрович Елачич (1880-
1944) - натуралист, просветитель и педагог. // Рус. орнитол. журн. - 2011. - Том 20. Экспресс-выпуск № 678. URL: http://www.russiangrave. ru/assets/files / 88613717 Elacic.pdf \{дата обрашения: 15.09 .16 г.

23. Харчук, Ю. И. Голуби от А до Я / Ю. И. Харчук. - Ростов н/Д: Феникс, 2005. - 318 с.

24. Юшкевич, С. С. Голуби. История красноголового голубя, его жизнь и приключения / С. С. Юшкевич. - М. : И. Кнебель, 1914. - 217 с. 


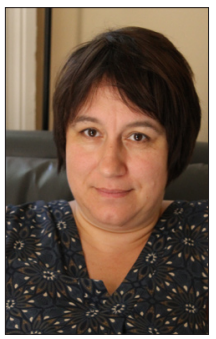

\author{
С. Г. Маслинская
}

МЕУТОМИМЫЙ БОРЕЦ СО СКАЗКОЙ (КРИТИКА ДЕТСКОЙ ЛИТЕРАТУРЫ В ТРУДАХ Н. КРУПСКОЙ)

УДК 82.09

ББК 83.8г(2)6-8 Крупская Н. К.

В статье предпринята попытка проанализировать противоречивую роль Н. К. Крупской как критика детской литературы, ее участие в формировании новой парадигмы оџенки детской литературы. Второй фокус исследования - изучение механизмов использования наследия Н. К. Крупской в последуюших конџепџиях советской детской литературы, когда ее имя позволяло легитимировать взаимоисключаюшие трактовки того или иного явления в советской детской литературе.

Ключевые слова: Н. К. Крупская; критика детской литературы; советская детская литература; педагогические идеалы.

S. G. Maslinskaya

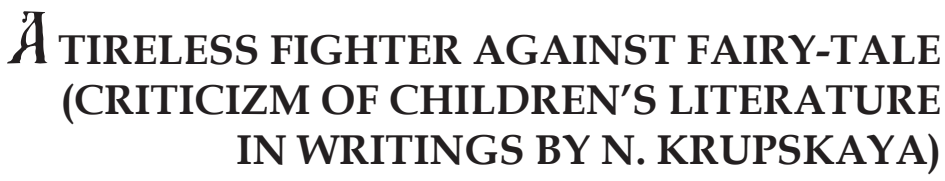

This article aims at understanding the contradictory rile played by N. Krupskaya as a critic of children's literature. I analyze her participation in the formation of the new paradigm for evaluation of children's literature. A special attention is payed to the ways in which her writings were used in later conceptualizations of Soviet children's literature. I argue that using her name allowed authors of textbooks on children's literature and of prefaces to the editions of her work to legitimize mutually exclusive treatments of one or the other phenomenon in children's literature.

Key words: Nadezhda Krupskaya; children's literature criticism; soviet children's literature; pedagogical ideals.

Вклад Н. Крупской в создание советской системы образования изупериода ${ }^{1}$. В историко-педагогических

\footnotetext{
${ }^{1}$ Статья подготовлена при поддержке гранта РГНФ «Воспитание нового читателя: литература для детей в педагогической критике и цензуре (1864-1934)» 15-06-10359.
} 
исследованиях выделены истоки ее педагогических идей, прояснены исторические контексты большевистских образовательных проектов, в которых она участвовала, выявлена нелинейная эволюџия педагогических воззрений Крупской в 1920-1930-е годы ${ }^{1}$. То же самое можно сказать об историках библиотечного дела в стране, изучавших ее роль в становлении библиотек в Советской России ${ }^{2}$. На пересечении этих двух направлений исследований находится изучение фигуры Крупской как теоретика и критика детской литературы. И здесь мы обнаруживаем зияющую пустоту - таких исследований нет ${ }^{3}$.

Была ли Крупская теоретиком и критиком детской литературы? Каков ее вклад в разработку представлений о советской детской литературе? Учебники по истории отечественной детской литературы говорят о ее роли совершенно определенно: «Неоџенимый вклад в теорию и критику детской литературы внесен
Н. К. Крупской и А. В. Луначарским. В статьях «Наши ребятам нужна книжка, которая воспитывала бы из них интернаџионалистов», «Пусть заговорят страниџы детских книг о борьбе и победах рабочих масс» и др., Н. К. Крупская выступала организатором и пропагандистом новой литературы для советских детей» ${ }^{4}$. Таким образом, теория и критика детской литературы в суждениях советской поры скреплены с организаторской и пропагандистской работой Н. К. Крупской, хотя совершенно очевидно, что прямой зависимости между теорией и пропагандой могло бы и не быть. Но в случае с Н. К. Крупской, пожалуї, эта связь подмечена верно. Ее критика детской литературы имела конкретные организаџионные следствия, а теория носила пропагандистский, а не аналитический характер.

И второе важное уточнение. В советской историографии Н. К. Крупская постоянно характеризуется как основатель советской детской лите-

${ }^{1}$ См., прежде всего недавнее исследование: Красовицкая Т. Ю. Н. К. Крупская - идеолог большевистской реформы образования // Труды Института российской истории. Вып. 5 / Российская академия наук, Институт российской истории; отв. ред. А. Н. Сахаров. М. 2005. C. 244-272.

${ }^{2}$ Теоретическое наследие Н. К. Крупской по вопросам библиотечного дела и его влияние на перестройку работы библиотек: Материалы Всероссийской науч.-практ. конф. 28 февраля-2 марта 1989 г. Уфа. 1990.

3 Упоминания удостаивается только борьба со сказкой 1920 -х годов и участие в ней Крупской. Впрочем, это сравнительно недавние работы, и, как правило, в них даны беглые характеристики кампании в целом, а не изучение позиции Крупской в отношении сказки и детской литературы в целом. См., напр.: Balina M., Rudova L. Introduction: Russian Children's Literature: Changing Paradigms. / M. Balina, L. Rudova // Slavic and East European Journal. Vol. 49. № 2 (2005). Р. 191. Исключение составляет исследование Жаклин Олич, посвященное общей характеристике взглядов Н. К. Крупской на детскую литературу. Оно составляет часть ее монографии Olich Jacqueline M. Competing Ideologies and Children's Literature in Russia, 1918-1935. VDM Verlag. 2009. Главу о Крупской в русском переводе см.: Олич Жаклин. Новый взгляд на товарища Крупскую // Конструируя детское: филология, история, антропология. Москва : Азимут ; Санкт-Петербург: Нестор-История. 2011. 550 с. С. 78-94. ${ }^{4}$ Детская литература: учеб. пособие для сред. проф. образования / Под ред. Е. Е. Зубаревой. М.: Просвещение, 1989. С. 243. 
ратуры (наряду с М. Горьким), новатор в области теории детской литературы и «неутомимый бореџ» за совершенствование книг для детей. Однако новаторство Н. К. Крупской было сильно преувеличено. Она сама ничего нового не придумала (ни в теории школьного образования, ни в библиотечном деле, ни в теории детской литературы), но с недюжинным энтузиазмом перерабатывала, контаминировала и синтезировала опыт своих предшественников и коллег, в том числе и западных. Ее эрудиџия и хватка, действительно, позволили ей занять ключевые позиџии в системе просвещения в Советской России организаторский и пропагандистский талант Н. К. Крупской нашел себе достойное применение.

Остановимся подробнее на названных особенностях ее вклада в теорию и критику детской литературы.

\section{Необходимо создать богатую детскую литературу}

Теория детской литературы в 1920-е годы, когда Н. К. Крупская стала писать на эту тему, была достаточно хорошо разработана. Настолько хорошо, насколько вообще к этому моменту она была разработана в отечественной филологической науке. В работах Н. Саввина, В. Родникова и Н. Чехова дискутировались проблемы детской литературы как особого вида словесного творчества для аудитории, определяемой по возрастному принџипу ${ }^{1}$. Прежде всего, обсуждалось соотношение воспитательного и эстетического модуса в произведениях для детей. Н. Чеховым была предложена классификаџия детской литературы по происхождению тех или иных произведений (из фольклора, массовой беллетристики и т. п.). И Н. Саввин, и Н. Чехов изучали литературный проџесс для детей с точки зрения его синхронизаџии с общим литературным процессом в отношении стилей и направлений. Н. Чеховым была выдвинута и обоснована гипотеза о стилевом отставании детской литературы от общей. В 1910 -е годы в России сформировалось еще одно исследовательское поле: соџиология и психология детского чтения, и соответственно разрабатывалась типология читателей-детей в зависимости от соџиальных, психологических, гендерных и других особенностей (работы А. Покровской, Н. Рыбникова, Х. Д. Алчевской и др.).

Из всего разнообразия названных теоретических проблем детской литературы и детского чтения Н. К. Крупскую интересовали немногие. В первую очередь, те, что были связаны с содержательной стороной произведений для детей. Н. К. Крупская вслед за большинством дореволюџионных теоретиков детской литературы

\footnotetext{
${ }^{1}$ Чехов Н. В. Детская литература. М. : Книгоиздательство «Польза». 1909; Чехов Н. В.Введение в изучение детской литературы: изложение лекций народным учителям на летних курсах по вопросам детской литературы и детского чтения. М.: Изд-во Сытина. 1915; Саввин Н. А. Основные направления детской литературы. Л.: Брокгауз-Эфрон. 1926; Родников В. П. Очерки детской литературы. Киев. 1912.
} 
признавала только реализм. И понимала она его вместе с демократическими критиками XIX века как метод, лишенный фикџиональности, как «отражение действительности». Этот художественный метод казался ей наиболее отвечающим и эстетическим, и воспитательным задачам детской литературы: «Если мы хотим создать настоящую книжку для чтения, то мы должны побольше вглядываться в окружающую жизнь; там мы можем почерпнуть такое количество материала, которое даст возможность создать нужную ребенку книжку»1.

Только реалистическое изображение соџиальной действительности, с ее точки зрения, могло удовлетворить запросам юных читателей независимо от возраста: дошкольников и подростков. При этом в ее суждениях нет опоры и даже ссылок на исследования читательских интересов, которые в 1920-е годы велись весьма активно. Исследования показывали другие результаты ${ }^{2}$, но Н. К. Крупская оставалась верна наследию В. Г. Белинского и Н. Г. Чернышевского.

Если Н. Чехов еше в 1915 году критически представлял засилие реализма в детской литературе: «Идея передачи детям реальных знаний в виде занимательного рассказа оказалась очень живучею и создала џелый ряд детских писателей, обладавших очень скромным литературным талантом, но полагавших, что самое важное в детской книге не художественная форма, а реальное содержание» ${ }^{3}$, то спустя десять лет его оппонент Н. Саввин с убежденностью ратовал за «художественный реализм в детской книге, органически слитый с дидактизмом, как результатом влияния художественного образа» ${ }^{4}$. Таким образом, позиџия Крупской неспеџифична - это позиџия тех, для кого реализм - единственный легитимный художественный метод.

И вторая теоретическая проблема, которая ее беспокоила, - это прагматика детской литературы. Здесь она также вслед за своими дореволюџионными предшественниками утверждала воспитательный потенџиал детской литературы как ее неотъемлемое свойство. Она не утруждала себя обращением к аргументам: аргументы уже были выработаны до нее в трудах дореволюџионных педагогов. В основе этих аргументов лежала догматическая убежденность в том, что книга влияет на ребенка прямо и непосредственно - «учит жизни».

\footnotetext{
${ }^{1}$ Крупская Н. К. Об учебнике и детской книге для I ступени (Речь на I Всероссийской конференции по учебной и детской книге. 8-15 мая. 1926) // На путях к новой школе. 1926. № 7-8. C. 3-13.

${ }^{1}$ Позднякова Ю. Опыт сравнения детских читательских интересов по методу спроса за 1925 и 1928 годы // Красный библиотекарь. 1929. № 10-11. С. 93-99; Зингерман А. Опыт постановки справочной детской читальни (Киевская центральная детская биб-ка) // Красный библиотекарь. 1926. № 9. С. 51.

${ }^{3}$ Чехов Н. Введение в изучение детской литературы: изложение лекций народным учителям на летних курсах по вопросам детской литературы и детского чтения. М. : Изд-во Сытина. 1915. C. 39-40.

${ }^{4}$ Саввин Н. Принципы критики детской литературы. М., 1923. С. 30.
} 
При этом Н. К. Крупская не уставала говорить о необходимости эстетического качества литературы, адресованной детям. В отличие от К. Чуковского и С. Маршака, в этом вопросе с ней солидаризовавшихся, она, не будучи литератором-практиком, в своих представлениях о качестве литературного текста оставалась на уровне читателя-профана. Главное - әто чтобы было «просто и понят но». Мантры о простоте и понятности переходили из публикаџии в публикаџию: простота и ясность, по Крупской, нужны для того, чтобы максимально результативно донести воспитательные идеи. Таким образом, единственное назначение детской литературы, с точки зрения Н. К. Крупской, - это все-таки воспитание. В ее устах - воспитание будущих строителей коммунизма.

Итак, метод и прагматика - два фокуса, которые интересовали теоретика Н. К. Крупскую. Все остальные проблемы: жанровый состав и его спеџифика, функџиональные виды литературы, возрастная адресаџия, иллюстрирование, поэтика, - все эти аспекты находились в подчиненном положении к двум основным векторам. Отбор материала, приемы создания образа, в том числе и визуального, жанровые структуры - все должно было находиться в орбите реалистического искусства, призванного решить воспитательные задачи.

Отмечу существенную особенность ее теоретических рассуждений, Н. К. Крупская высказывалась по теоретическим вопросам в модальности необходимости и долженс- твования. Она не фиксирует и не описывает явления литературного порядка, а призывает и наставляет, какими эти явления должны быть. Долженствование (какой должна быть детская литература) - в принџипе типичная черта педагогического критического (не теоретического!) дискурса о детской литературе, но у Крупской она соседствует с побудительными императивами и, в конечном итоге, сводится к инструктивному типу дискурса («пишите так»). Дескриптивная поэтика филологически ориентированных спејиалистов, таких, как Н. Чехов и Н. Саввин, сменилась с приходом Крупской на поэтику нормативную.

Очевидно, что материал сопротивлялся: детская литература к середине 1920-х годов, когда Н. К. Крупская стала выступать как теоретик, имела полный спектр художественных методов создания образов и далеко выходила за пределы просвешенческой модели искусства как воспитательного средства (модернизм дал немало образџов антипедагогической детской литературы). Материал сопротивлялся и нуждался в нормативной шлифовке и коррекџии. И на этом пути - пути критики литературной продукџии для детей - Н. К. Крупская также была непреклонна.

\section{Стоит ли эту книжку читать? \\ В џелом, критическое наследие} Н. К. Крупской достаточно велико (составляет 10-й том ее Полного собрания сочинений), но посвящено оно по преимушеству разбору новинок педагогической литературы по вопросам организаџии образования, политпрос- 
вешения и библиотечного дела. В то же время удельный вес статей, связанных с детской литературой, крайне невелик, ограничивается десятком (!) публикаџий.

За новинками детской литературы Н. К. Крупская регулярно не следила. Тем не менее, обычной из ее уст была резко негативная оџенка состояния текущего состояния литературного проџесса для детей - «на книжном рынке очень много хламу, <..> масса бессодержательных, нелепых, уродливых книг» ${ }^{1}$ (1927).

Ее редкие отзывы на выходившие детские книжки появлялись тогда, когда она, готовясь к какому-нибудь выступлению по организаџионным вопросам на конференџии для учителей или библиотекарей, заглядывала в каталоги издательств, выбирала подборку книг и просматривала их ${ }^{2}$. На таком материале, как она сама признавалась, построен, например, ее отзыв о книгах, выпущенных Госиздатом в 1927 году.

Единичны ее отзывы на издания вне связи с выступлением на какомнибудь совещании. Можно привести буквально два примера, и оба характерны. Первый пример - это издание сказок Д. Н. Мамина-Сибиряка, предпринятое издательством Г. Ф. Мириманова в 1927 году, а второй - отзыв о сказке К. И. Чуковского «Крокодил», опубликованный в газете «Правда» 1 февраля 1928 года.

Если первая реџензия прошла незамеченной (мы к ней еще вернемся), то вторая вызвала џелую кампанию по развенчанию сказочного творчества К. И. Чуковского. За детского поэта вступился М. Горький, опубликовавший ответное письмо ${ }^{3}$. На страниџах «入итературной газеты» развернулась дискуссия, возобновлявшаяся в течение двух лет. Критическая кампания все более приобретала черты откровенной травли писателя. К. $\mathrm{C}_{\text {вердлова }}{ }^{4}$ в своей статье «О „чуковщине“» вдохнула вторую жизнь в этот ярлык ${ }^{5}$, понимая под ним «идеологию вырождаюшегося мешанства, культ

${ }^{1}$ Крупская Н. К. К вопросу об оценке детской книжки // На путях к новой школе. 1927. № 1. C. 30.

${ }^{2}$ См., например: Крупская Н. К. Об учебнике и детской книге для I ступени (Речь на I Всероссийской конференции по детской и учебной книге) // На путях к новой школе. 1926. № 7-8. С. 3-13; Крупская Н. К. О детской библиотеке и детской книге (Доклад на конференции работников детских библиотек 9 февраля 1927 г.) Н. К. Крупская // Красный библиотекарь. 1927. № 3. С. 25-31.

${ }^{3}$ Горький М. Письмо в редакцию от 25 февраля 1928 г. // Горький о детской литературе: Статьи, высказывания, письма. 2-е изд. М., 1958. С. 186. Впервые: Правда. 1928. 14 марта.

${ }^{4}$ Свердлова Клавдия Тимофеевна (1876-1960) - советский партийный деятель, жена Я. М. Свердлова. В 1925-1931 гг. заведующая отделом детской литературы и отделом учебников ОГИЗ.

${ }^{5}$ Понятие «чуковщина» возникло задолго до дискуссий 1920-х годов, в частности, еще до революции его неоднократно использовал С. Ф. Либрович, писавший под псевдонимом Лукиан Сильный (см., например, Сильный Лукиан «Что такое «Чуковщина»?: Вопрос без ответа // Вестник литературы. 1909. № 3. СПб. 78-80). В дореволюционном словоупотреблении под «чуковщиной» понималась поверхностная, злая критика, критиканство. 
отмираюшей семьи и мешанского детства» ${ }^{.}$. Ей вторила родительская общественность, по убеждению которой, «Муха-џокотуха» подрывает веру детей в торжество коллектива, в ней выражено сочувствие кулаџкой идеологии ( «А жуки рогатые, мужики богатые»), она восхваляет «мещанство и кулаџкое накопление» и дает «неправильное представление о мире животных и насекомых» ${ }^{2}$. В травле участвовали не только педагоги и цензоры, но и товарищи Чуковского по литературному џеху. Гневное письмо, опубликованное в «ภитературной газете» 27 января 1930 года, подписали тридџать писателей, среди них были А. Барто, ᄉ. Остроумов, С. Ауслендер. В этом письме среди прочего осуждались строки:

А нечистым трубочистам

Стыд и срам, стыд и срам...

Писатели интерпретировали эти строки как иронию над рабочим классом, невозможную в советской детской литературе ${ }^{3}$. Отражение в сказках мелкобуржуазной позиџии писателя, по мнению критиков, привело Чуковского к игнорированию советского читателя-ребенка: «<...> пришел новый рабоче-крестьянский малыш. Он хлопнет ручкой по книге и спросит: “Это про СССР?” И узнав, что не СССР, а умывальник, досадливо пожмет шестилетним плечом» ${ }^{4}$. Чуковского ругали за «культивирование в детской литературе ритмики и приемов народного творчества ${ }^{5}$, за использование особенностей детской речи, за «тенденџию позабавить ребенка» ${ }^{6}$. Два года приџельной травли привели к тому, что в конџе 1929 года в одном из декабрьских номеров «入итературной газеты» появилось отречение Чуковского от собственных сказок, которые он назвал «старинными», и от заповедей детского писателя, сформулированных им совсем незадолго до этого. Здесь же Чуковский пообещал написать «Детскую колхозию» ${ }^{7}$ (но обешания впоследствии не выполнил).

Организаторская роль Н. К. Крупской в этой истории очевидна. Ее едкая и раздраженная реџензия как будто нажала спусковой крючок - спеџиалисты и общественность бросились топтать автора «Бармалея» и «Мойдодыра». Среди других примеров отношений между советской властью и детскими, да и взрослыми писателями эта ситуаџия ничего уникального из себя не представляла: партийный чиновник провоџирует -

\footnotetext{
${ }^{1}$ Свердлова К. О «чуковщине» // Красная печать. 1928. № 9/10. С. 94.

${ }^{2}$ Мы призываем к борьбе с «чуковщиной» (Резолюция общего собрания родителей Кремлевского детсада) // Дошкольное воспитание. 1929. № 4. С. 74.

${ }^{3}$ [Открытое письмо М. Горькому] // Литературная газета. 1930. 27 янв.

${ }^{4}$ Гринберг Анна. Книги бывшие и книги будущие (для маленьких детей) // Печать и революция. 1925. № 5/6. С. 247.

5 [Группа работников детской книги] Возрождение «россеянства» // Книга и революция. 1929. № 1.C. $25-28$.

${ }^{6}$ Флерина Е. С ребенком надо говорить всерьез // Литературная газета. 1929. 30 дек.

7 Чуковский К. [Заявление в ГИЗ от 10 декабря 1929 г.] // Литературная газета. 1929. 30 дек.
} 
профессиональное сообшество (писатели, библиотекари, учителя) подхватывают и развивают идеи. И тем не менее при том, что затравочная статья Н. К. Крупской о «Крокодиле» неоднократно попадала в поле зрения историков литературы (ее џитируют практически все, кто обрашается к исследованиям «борьбы со сказкой» в 1920-е годы), мало кто прочитал ее внимательно именно с точки зрения критических претензиї, которые сформулировала Н. К. Крупская. Обличительный и отторгающий пафос усвоили все - и современники, и историки, - но суть претензий и критерии, на основе которых Н. К. Крупская стигматизирует творчество К. И. Чуковского, не рассматривались. Восполним этот пробел.

Практически половина статьи посвящена не «Крокодилу», а Некрасову, точнее, статье К. Чуковского «Жизнь Некрасова»: Н. К. Крупская резко критикует ее автора за то, что «мелкими плевками заслоняет он личность поэта „мести и печали”»1. Критические пассажи, направленные против самой сказки, обращены не на антропоморфизм персонажей, как зачастую виделось ее последователям, его как раз Н. К. Крупская признает «смешным». Хотя она с некоторым пренебрежением приводит примеры антропоморфической «галиматьи», все же не человеческий облик зверей ее раздражает более всего (и это на фоне развернувшейся в 1928 году дискуссии о допустимости антропоморфизма в детской книжке). Не приемлет она того, как К. Чуковский изображает «народ» и семейный уклад крокодила, то есть по сути дела, как художник показывает соџиальную действительность. Сказка, действительно, отсылает к историческим и соџиальным реалиям, и Чуковский действительно весьма нелиџеприятно рисует народные массы трусливыми и злобными. Если для Чуковского это и игра и не игра одновременно (совершенно очевидно, что К. И. Чуковский не был народником и к оџенке нравственной силы «народа» подходил весьма сдержанно, как и его патрон М. Горький), то для «пламенной революџионерки» такой образ был неприемлем.

Вторая претензия Крупской основывалась также на отборе соџиального материала: дом главного героя - это не рабочий барак или крестьянская изба, а дом зажиточного горожанина, который у Крупской ассоџиирован с мещанским соџиальным слоем и, в конечном итоге, с главным идейным врагом - буржуазией. Больше никаких содержательных критических замечаний в ее рецензии не было. Таким образом, фильтры, которые предлагает Н. К. Крупская, это не жанровые модели (сказка) и не игровая поэтика, а исключительно источники сюжетов и образов - «материал из жизни».

Но и в уже упоминаемой выше реџензии на издание сказок Д. Н. Мамина-Сибиряка ее беспокоило то же самое: архимелкособственническая идеология». Смущает Крупскую, что в сказках «изображаются под видом зверей люди-одиночки, думающие

\footnotetext{
${ }^{1}$ Крупская Н. К. О «Крокодиле» Чуковского // Правда. 1928. 1 февр.
} 
только о себе, люди эгоистичные или глупые, холодные резонеры» ${ }^{1}$. Она критикует отбор материала: «эгоистичные рассуждения» свойственны людям, но в детской книжке их быть не должно.

Здесь вновь прослеживается ее теоретическое кредо: реализм должен быть критическим и одновременно должен «преображать» действительность, конструировать мир, в котором все подчинено марксистской телеологии. На первый взгляд, Крупская разрабатывает теорию соџреализма, спустя пять лет провозглашенную М. Горьким.

Однако вера в воспитательную прагматику детской литературы и пристрастие к реалистическому мимесису, повторюсь, не были изобретением Крупской, как представляли это впоследствии ее биографы и историки литературы. В действительности, Н. К. Крупская дублирует практически слово в слово своих дореволюџионных предшественников. Прогрессивная дореволюџионная критика, то есть та критика, которая располагала издательскими ресурсами (журналами «Что и как читать детям» и «Новости детской литературы») и задавала основной тон в оџенке новинок и переоџенке классики, - также исходила из прерогативы реализма перед любыми другими методами художественного письма.
Так, Надежда Шохор-Троџкая, дочь авторитетного педагога-математика С. И. Шохор-Троџкого, учительниџа Мало-Троиџкого начального училища, негативно относится и к модернистским экспериментам, и к сентиментальному направлению в детской литературе. В первом случае она подвергает обструкџии журнал «Галчонок» за легкомыслие, «гадкие анекдоты из жизни разврашенных, безнадежно испорченных детей», ссылаясь на то, что время диктует совсем другие џенности: «И это как раз теперь, когда џелые группы людей ведут упорную, кропотливую борьбу за новую лучшую школу, за новое здоровое воспитание» ${ }^{2}$. Ее риторические пассажи родственны жесткому стилю Крупской, она характеризует образность и сюжеты «Галчонка» как «калейдоскоп грубых карикатур, душещипательных или идейно-нравоучительных рассказов» и выносит суровый вердикт: «гоготать, так гоготать, зачем же профанировать настоящее чтение» ${ }^{3}$. Такой же, как через десять лет вынесет К. Чуковскому Н. К. Крупская.

И во втором случае Н. ШохорТроџкая обрашается к реџензированию серии книг Горбунова-Посадова «Малым ребятам», которую она в течение долгого времени предлагала для чтения своим ученикам, пересказывает отриџательные отзывы детей и ре-

\footnotetext{
${ }^{1}$ Крупская Н. К. Сказки Мамина-Сибиряка // На путях к новой школе. 1927. № 4. С. 156. (Цит. по: Крупская Н. К. Сказки Мамина-Сибиряка // Н. К. Крупская о детской литературе и детском чтении. М. 1954. С. 32.)

${ }^{2}$ Шохор-Троикая Н. Из обзора детских журналов (Галчонок) // Русская школа. 1912. Майиюнь. ІІІ отдел. Критика и библиография. С. 65.

${ }^{3}$ там же. С. 68.
} 
зюмирует: «Сейчас, через десять лет, еше ярче представляется мне отриџательность таких нравственных сентиментальных книжечек <..> $>$. Уважаю в них большую работу, заботливое, внимательное, любовное отношение к делу, преклонение перед добром и правдой, - но ведь получается-то не то совсем: не добро, а сентиментальность. $<\ldots>$ Призыв тут не к добру, а к жалости, снисхождению, милости. Не то все это» ${ }^{1}$.

Н. Мурзаев в том же 1912 году задает детской литературе те же антибуржуазные координаты: «Хорошая детская книжка должна быть здоровою, чистою вешью. <..> Здоровая же книга та, которая стремится описывать скорее добро, чем зло, и вводит ребенка в честную среду, где все говорит (языком правдивого образа (курсив автора - С. М.)) о значении труда и ценности добра» ${ }^{2}$.

Требования правдивости, честности, требования «противопоставить "скучной" книжке книжку талантливую, искрящуюся, заставляющую ребенка смеяться, радоваться, понимать, как прекрасна жизнь» ${ }^{3}$ звучали все первое тридџатилетие XX века со страниџ педагогических и библиотечно-критических изданий. И до, и после Крупской.

Показательно, что та же $\mathrm{H}$. Шохор-Троџкая, критикуя серию
«В помошь народной школе» Я. В. Борисова, пишет: «Жуть охватывает при мысли, что к детям крестьянским, городским, которые так неустойчивы в смысле грубых слов, попадут такие книги. Наизусть выучатся. В воздухе будут висеть...» ${ }^{4}$. Критик в 1912 году предъявляет к серии те же претензии, что и Крупская и ее сторонники к Чуковскому, который использовал язык мешанской улиџы в «Крокодиле». Поиски нового языка в детской книге начались не в 1920-е годы, как принято считать, а в 1910 -е - поэтому расхожее мнение, что Чуковскому не повезло с критиком - Крупской, - заблуждение. Выпусти он «Крокодила» в 1912 году, как выпустил Я. В. Борисов «уличную частушку» (так определяет Н. Шохор-Троџкая известные куплеты «Дивная корзинка» («Шла старушка мимо рынка»)), нашелся бы критик не менее строгий, чем Н. К. Крупская.

\section{Неутомимый борец}

Во второй половине 1930-х годов авторитет Н. К. Крупской был поколеблен. А. П. Бабушкина, С. Маршак и К. Чуковский, каждый со своей стороны, высказались о перегибах Наркомпроса в вопросах борьбы со сказкой и именно Н. К. Крупскую имели в виду, когда помянули недобрым словом «приснопамятную комис-

\footnotetext{
${ }^{1}$ Шохор-Троикая Н. К обзору детских книг. «Малым ребятам». Изд. И. И. Горбунова-Посадова // Русская школа. 1912. № 2 (февраль). С. 48-50.

${ }^{2}$ Мурзаев В. Борьба с дурной книгой // Педагогический листок. 1912. № 4. С. 251-259.

${ }^{3}$ От редакции // Книга детям. 1928. № 1. С. 6.

${ }^{4}$ Шохор-Троикая Н. К обзору детских книг. «В помощь народной школе», под ред. Борисова, из-е Тов. Сытина. М. // Русская школа. 1912. Март. ІІІ отдел. Критика и библиография. C. 52 .
} 
сию ГУСа». Однако всерьез критиковать ее взгляды на детскую литературу как «могушественное средство коммунистического воспитания» никто не отважился.

Спустя двадџать лет - в начале 1950-х годов, когда один за другим стали выходить сборники высказываний о детской литературе авторитетных критиков и педагогов ${ }^{1}$, настал черед и издания Н. К. Крупской. В 1952 году вышла лекџия Н. Н. Житомировой «Н. К. Крупская о руководстве детским чтением», в которой были суммированы установочные сентенџии Крупской о детском чтении ${ }^{2}$. А в 1954 году увидела свет небольшая брошюра, состояшая из фрагментов ее выступлений, в которых она касалась вопросов детской литературы и детского чтения ${ }^{3}$. Состав этой брошюры показателен тем, что в нее не вошла самая резонансная публикаџия Н. К. Крупской - реџензия о «Крокодиле». Составители этого сборника ее статей решили воздержаться от перепечатки знаменитой реџензии. Двумя годами ранее в одной из первых учебных программ по советской детской литературе критическая позиџия Крупской еще была представлена в разделе по изучению творчества К. Чуковского:

«Сказки Чуковского (Мухина свадьба, Тараканище, Мойдодыр).
Использование народного творчества. Мастерство стиха. Узость тематики, недооџенка познавательных возможностей ребенка - основные недостатки сказок Чуковского. <...> Недооџенка воспитательных функџй̈ поэзии. Критика творчества Чуковского в статьях Н. К. Крупской» ${ }^{4}$.

Но через пять лет, в 1957 году, при том, что критика творчества Чуковского сохраняется, имя Крупской уже снято:

«Недооџенка Чуковским познавательных возможностей ребенка и воспитательных функџй поэзии в его произведениях и статьях о детской литературе. Искаженный показ Отечественной войны в сказке «Одолеем Бармалея». Пересмотр Чуковским своих теоретических позиџий в книге «ОТ двух до пяти» (изд. 1955 г.) $»^{5}$.

И в том же году выходит учебник под ред. О. В. Алексеевой, в котором К. Чуковского окончательно и уже бесповоротно возвращают в пантеон советских детских писателей:

«Дискуссия закончилась победой зашитников фантастики и сказки для детей: стали издаваться русские сказки и народов СССР, А. С. Пушкина, переводные сказки братьев Гримм, Андерсена. Вторая половина 20-х годов была ознаменована в детской

\footnotetext{
${ }^{1}$ Белинский В. Г., Чернышевский Н. Г., Добролюбов Н. А. О детской литературе / сост. С. М. Шиллегодский. М.: Гос. изд-во детской лит-ры. 1954; ратуре. М. : Детгиз. 1952.

${ }_{2}^{2}$ Житомирова Н. Н. Н. К. Крупская о руководстве детским чтением. Лекция для студентовзаочников по курсу «Руководство детским чтением». М.: Госкультпросветиздат, 1952. 24 с. ${ }^{3}$ Крупская Н. К. О детской литературе и детском чтении. М.: Детгиз. 1954.

${ }^{4}$ Советская детская литература. Программа курса для библиотечных институтов. М.: 1952.

${ }_{5}^{5}$ Советская детская литература. Программа курса для библиотечных институтов. М.: Советская Россия. 1957.
} 
литературе быстрым ростом поэзии для детей. Маяковский, Маршак, Чуковскиї, используя традиџии народного творчества и классической поэзии, создавали для детей стихи совершенно нового качества» 1 .

О том, кто иниџиировал и поддерживал дискуссию своими многократными выступлениями, учебники будут молчать. В 1952 году непримиримые противоречия в позиџиях Крупской и Горького, выразившиеся в скандальной пикировке на страниџах «Правды», будут тщательно скрыты и даже, более того, Н. Н. Житомирова заявит прямо противоположное: «Следует отметить идейную близость ряда статей и выступлений Н. К. Крупской с высказываниями А. М. Горького, который выступал в те же годы (конец 20-х - начало 30 -х годов) как организатор и теоретик советской детской литературы и выдвигал большие важные проблемы содержания чтения наших школьников и молодежи» ${ }^{2}$.

А уже к конџу 1960-х годов Н. К. Крупскую изобразят зашитником сказок, пронијательным и рассудительным полемистом, сохранившим «трезвый, реалистический взгляд»на сказку. Само сочетание сказки и реализма не смущает Н. Медведеву, все- ми силами старающуюся представить Н. К. Крупскую верным соратником М. Горького, а не его оппонентом ${ }^{3}$.

В следуюшем издании трудов Крупской о детской литературе, предпринятом в 1979 году, также не будет реџензии о «Крокодиле» ${ }^{4}$. И спустя еще пять лет в очередном учебнике проблема неоднозначности позиџии Крупской будет наконеџ проговорена и снята: «В критической литературе можно встретить суждение о том, что Надежда Константиновна была противником сказки. <..> Отдельные писатели и педагоги в то время зашищали переиздание любых сказок. Вплоть до мистических, противопоставляя им книги о современности. Тем самым они стремились отвлечь внимание детей от современной жизни... Некоторые педагоги впадали в другую крайность и выступали вообще против чтения детских сказок, фантастики и даже произведений классической литературы на том основании, что они якобы отвлекают детей от активного вмешательства в жизнь. Надежда Константиновна в период острой борьбы вокруг сказки сумела сохранить трезвыц̈, реалистический (курсив мой - С. М. ) взгляд на этот вопрос и не впадала ни в одну из крайностей» ${ }^{5}$.

\footnotetext{
${ }^{1}$ Детская литература. Пособие для пед. училищ / О. В. Алексеева, Е. П. Брандис, Г. П. Гроденский и др. М.: Учпедгиз. 1957. 334 с.

${ }^{2}$ Житомирова Н. Н. Н. К. Крупская о руководстве детским чтением. Лекция для студентовзаочников по курсу «Руководство детским чтением». М.: Госкультпросветиздат, 1952. С. 7.

${ }^{3}$ Медведева Н. «Детский писатель - большое звание». Н. К. Крупская о детской литературе // Детская литература. 1969. № 2. С. 20.

${ }^{4}$ Крупская Н. К. О детской литературе и детском чтении: Избранное / Н. К. Крупская. М. Детская литература. 1979.

${ }_{5}^{5}$ Чернявская И. С., Розанов И. И. Русская советская детская литература. Мн.: Вышейш. шк., 1984.
} 
Резкие и жесткие формулировее убежденность в недопустимости ее активное неприятие творчества К. Чуковского - все эти составляющие ее последовательной позиџии 1920-х годов в советской историографии окажутся табуированными. В 1930-х Крупская под давлением авторитетов М. Горького, С. Маршака да и самого К. Чуковского свои взгляды на сказку подкорректирует. Но авторы советских учебников и журнальных статей по случаю ее очередного юбилея будут неутомимо создавать бронзовый образ неутомимого борџа, лишенного ошибок, владеюшего истинным знанием о детской литературе.

В своей простоте и Н. Медведева, и И. Чернявская, и И. Розанов сослужили недобрую службу доброй памяти Н. К. Крупской, которая при ки Н. К. Крупской о вреде сказки, волшебных сказок в детское чтение,

всех своих заблуждениях по поводу жанра сказки определила тем не менее основной вектор теории и критики детской литературы на весь советский период, да и за его граниџами. И в этом ей отказать нельзя. После нее критика детской литературы могла быть только реалистической, а теория - только педагогической. Все многообразие стилевых и жанровых поисков в детской литературе было уплотнено многочисленными последователями Н. К. Крупской в прокрустово ложе реалистической художественной системы с обязательным приписыванием ей воспитательной роли. Однако ограниченные одним методом рејептивные навыки педагогической критики еще не означали, что литературный проџесс станет им подчиняться. Свидетельством тому многоџветная картина советской детской литературы и бледный ее слепок, снятый советской педагогической критикой.

\section{Список литературы}

1. Белинский, В. Г., Чернышевский, Н. Г., Добролюбов, Н. А. О детской литературе / В. Г. Белинский, Н. Г. Чернышевский, Н. А. Добролюбов / сост. С. М. Шиллегодский. - М. : Гос. изд-во детской лит-ры, 1954. -430 с.

2. Гринберг, Анна. Книги бывшие и книги будушие (для маленьких детей) / А. Гринберг // Печать и революџия. - 1925. - № 5/6. - С. 247.

3. Горький, М. Письмо в редакџию от 25 февраля 1928 г. / М. Горький // Горький о детской литературе: Статьи, высказывания, письма. 2-е изд. - М., 1958. - С. 186. Впервые: Правда. 1928. 14 марта.

4. Горький, М. О детской литературе. / М. Горький. - М. : Детгиз, 1952. $-256 \mathrm{c}$.
5. [Группа работников детской книги] Возрождение «россеянства» // Книга и революџия. - 1929. - № 1. - С. 2528.

6. Детская литература. Пособие для пед. училиш / О. В.Алексеева, Е. П.Брандис, Г. П. Гроденский и др. - М. : Учпедгиз, 1957. - 334 с.

7. Детская литература: учеб. пособие для сред. проф. образования / Е. Е. Зубарева [и др.] ; под ред. Е. Е. Зубаревой. - Москва : Просвещение, 1989. - 156 с.

8. Житомирова, Н. Н. Н. К. Крупская о руководстве детским чтением. Лекџия для студентов-заочников по курсу «Руководство детским чтением» / Н.Н. Житомирова. - М. : Госкультпросветиздат, 1952. - 24 с. 
9. Зингерман, А. Опыт постановки справочной детской читальни (Киевская џентральная детская биб-ка) / А. Зингерман // Красный библиотекарь. - 1926. - № 9. - С. 51.

10. Красовиџкая, Т. Ю. Н. К. Крупская - идеолог большевистской реформы образования // Труды Института российской истории. Вып. 5. - Российская академия наук, Институт российской истории; отв. ред. А. Н. Сахаров. М., 2005. - С. 244-272.

11. Крупская, Н. К. К вопросу об оџенке детской книжки / Н. К. Крупская // На путях к новой школе. - 1927. № 1. - С. 30-33.

12. Крупская, Н. К. Об учебнике и детской книге для I ступени (Речь на I Всероссийской конференџии по детской и учебной книге) / Н. К. Крупская // На путях к новой школе. - 1926. - № 7-8. - С. 3-13. (ПС, 3, с. 225-240).

13. Крупская, Н. К. К вопросу о детской книжке / Н. К. Крупская // На путях к новой школе 1926. - № 11. C. 3-7.

14. Крупская, Н. К. О детской библиотеке и детской книге (Доклад на конференџии работников детских библиотек 9 февраля 1927 г.) / Н. К. Крупская // Красный библиотекарь. - 1927. - № 3. - C. 25-31.

15. Крупская, Н. К. О «Крокодиле» Чуковского / Н. К. Крупская / / Правда. - 1928. - 1 февр.

16. Крупская, Н. К. Сказки МаминаСибиряка / Н. К. Крупская // На путях к новой школе. - 1927. - № 4. C. 156.

17. Крупская, Н. К. О детской литературе и детском чтении / Н. К. Крупская. М. : Детгиз, 1954. - 80 с.

18. Крупская, Н. К. О детской литературе и детском чтении: Избранное / Н. К. Крупская. - М. : Детская литература, 1979. - 271 с.

19. Медведева, Н. «Детский писатель - большое звание». Н. К. Крупская о детской литературе. / Н. Медведева // Детская литература. - 1969. - № 2. - C. 19-23.

20. Мурзаев, В. Борьба с дурной книгой / В. Мурзаев / / Педагогический листок. - 1912. - № 4. - С. 251-259.

21. Мы призываем к борьбе с «чуковшиной» (Резолюџия обшего собрания родителей Кремлевского детсада) // Дошкольное воспитание. - 1929. № 4. - С. 74 .

22. Олич, Жаклин. Новый взгляд на товарища Крупскую / Жаклин Олич // Конструируя детское: филология, история, антропология. - Москва : Азимут ; Санкт-Петербург : Нестор-История, 2011. - 550 c.

23. От редакџии // Книга детям. - 1928. - № 1. - С. 6.

24. [Открытое письмо М. Горькому] // Литературная газета. - 1930. - 27 янв.

25. Позднякова, Ю. Опыт сравнения детских читательских интересов по методу спроса за 1925 и 1928 годы / Ю. Позднякова // Красный библиотекарь. - 1929. - № 10-11. - С. 9399.

26. Родников, В. П. Очерки детской литературы / В. П. Родников. - Киев: Тип. Императ. ун-та Св. Владимира, 1912. - $156 \mathrm{c}$.

27. Саввин, Н. А. Принџипы критики детской литературы / Н. А. Саввин. - M. : 1923. - 32 с..

28. Саввин, Н. А. Основные направления детской литературы / Н. А. Саввин. - Л. : Брокгауз-Эфрон, 1926. $126 \mathrm{c}$.

29. Сильный, Лукиан Что такое «Чуковшина»?: Вопрос без ответа / Аукиан Сильный / / Вестник литературы. - 1909. - № 3. - Стб. 78-80.

30. Свердлова, К. О «чуковшине»/ К. Свердлова / / Красная печать. - 1928. -№ 9/10. - C. 92-94. 
31. Советская детская литература. Программа курса для библиотечных институтов. - М. : Советская Россия, 1952.

32. Советская детская литература. Программа курса для библиотечных институтов. - М. : Советская Россия, 1957.

33. Теоретическое наследие $Н$. К. Крупской по вопросам библиотечного дела и его влияние на перестройку работы библиотек: Материалы Всероссийской науч.-практ. конф. 28 февраля-2 марта 1989 г. - УФа. - 1990.

34. Флерина, Е. С ребенком надо говорить всерьез / Е. ср лерина // Литературная газета. - 1929. - 30 дек.

35. Чернявская, И. С. Русская советская детская литература / И. С. Чернявская, И. И. Розанов. - Мн. : Вышейш. шк., 1984. - 512 с.

36. Чехов, Н. В. Детская литература / Н. В Чехов. - М. : Книгоиздательство «Польза», 1909. - 256 с.

37. Чехов, Н. В. Введение в изучение детской литературы: изложение лекџий народным учителям на летних курсах по вопросам детской литературы и детского чтения / Н. В. Чехов. - М. : Изд-во Сытина, 1915. - 79 с.
38. Чуковский, К. [Заявление в ГИЗ от 10 декабря 1929 г.] / К. Чуковский / / Литературная газета. - 1929. - 30 дек.

39. Шохор-Троџкая, Н. Из обзора детских журналов (Галчонок) / Н. ШохорТроџкая / / Русская школа. - 1912. - майиюнь. III отдел. Критика и библиография. C. 64-69.

40. Шохор-Троџкая, Н. К обзору детских книг «В помошь народной школе», под ред. Борисова, из-е Тов. Сытина / Н. Шохор-Троџкая // Русская школа. - 1912. - март III отдел. Критика и библиография. - С. 50-51.

41. Шохор-Троџкая, Н. К обзору детских книг. «Малым ребятам». Изд. И. И. Горбунова-Посадова / Н. ШохорТроџкая // Русская школа. - 1912. № 2 (февраль). - С. 48-50.

42. Olich Jacqueline M. Competing Ideologies and Children's Literature in Russia, 1918-1935. - VDM Verlag. 2009.

43. Balina M., Rudova L. Introduction: Russian Children's Literature: Changing Paradigms. / M. Balina, L. Rudova // Slavic and East European Journal - Vol. 49. - № 2 (2005). - P. 186-198. 
Научные дискуссии

\section{Маучные ДИСКУССИИ}

\section{С. Г. Новиков}

\section{«У СЕБЯ ПОД АЕНИНЫМ ЧИШУ...»: СОВЕТСКИЕ ВОЖДИ 1920-Х ГОДОВ ОБ ИДЕАЛЕ ВОСПИТАНИЯ}

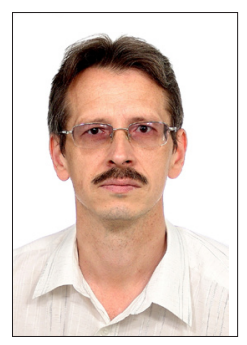

УДК 37.014

ББК 74.03

В статье рассматривается определение «наследниками Ленина» идеала воспитания. Утверждается, что данный идеал конџентрировал в себе как автохтонные (традиџионные, соџиоџентристские), так и заимствованные (современные, антропоџентристские) џенности.

Ключевые слова: идеал воспитания; обыденное педагогическое сознание; тотемизм; Правда; культура модернити; лидеры большевизма.

\section{S. G. Novikov}

\section{«I BRUSH HIMSELF UNDER LENIN...»: SOVIET CHIEFS ABOUT THE IDEAL OF UPBRINGING IN 1920-s}

The article deals with the definition of «the heirs of Lenin's» ideal of upbringing. It is argued that this ideal concentrated the autochthonous (traditional, sociocentristic) and the borrowed (modern, anthropocentric) values.

Key words: ideal of Upbringing; everyday pedagogical consciousness; totemism; Truth; culture of modernity; leaders of Bolshevism.

Крушение СССР в 1991 г. ознаменовало собой начало глубинной соџиокультурной, соџиально-экономической и политической трансформаџии, разорвавшей нравственную ткань обшества. Катаклизм потряс обшество до самых его оснований, не пощадив џенностного фундамента. Под сомнение были поставлены идеалы, считавшиеся незыблемыми большинством советских людей в течение многих десятилетий. Развенчанию подвергся 
и образ В. И. Ленина - фигуры некогда сакральной, осенявшей своими «заветами» политику всех поколений советских коммунистических вождей. $\mathrm{Ha}$ «самого человечного человека» обрушился не просто поток критики, но џелая лавина обвинений, в которых трудно бывало отделить реальные факты от инсинуаџий. Характерно, что и статисты, и солисты антиленинианы, очевидно, были некогда участ никами «Ленинских уроков» в совет ских школах, которые либо «внезапно прозрели», либо сумели, наконеџ, от крыто выразить свое истинное мнение о создателе большевистской партии. Такое «оборотничество» задело за живое многих наших соотечественников, проведя еще одну линию противостояния и в без того расколотом обществе.

Возникает вопрос: почему личность Ленина оказалась в џентре общественного внимания? Ответ на него очевиден: на протяжении шести десятилетий отечественная система образования упорно транслировала подрастающим поколениям образ основателя советской государственности в качестве идеальной личности, высшего нравственного образџа.

Главные черты этого образа обозначили уже в 1920-е годы «наследники Ленина». Последним термином мы обозначаем как «вождей» первого ранга - членов Политбюро ЏК РКП(б)-ВКП(б), реального верховного органа власти в стране
(Н. И. Бухарина, Г. Е. Зиновьева, ᄉ. Б. Каменева, И. В. Сталина, ᄉ. Д. Троџкого и др.), так и «вождей» второго плана - членов ЏК, видных теоретиков и пропагандистов большевизма, активных участников борьбы на «воспитательном фронте» (А. М. Коллонтай, 3. И. Аилину, А. В. Луначарского, М. Н. Покровского и др.).

Анализ текстов лидеров большевизма показывает, что они конструировали идеал воспитания для детей и молодежи, руководствуясь традиџионным манихейством - подходом к миру, представляющим его как арену борьбы Правды и кривды (высшего воплошения всего положительного и зла, соответственно) $)^{1}$. Качества идеальной личности своей запредельной высотой также выстраивались в логике традиџионного дистанџирования сущего и должного (последнее персонифиџировалось в личности Ленина как выразителе сакрально нормативного начала). Подобно носителям обыденного русского педагогического сознания, большевистские вожди, с одной стороны, относили идеальный образ основателя партии-государства «к сфере принџипиально невыполнимого», с другой - требовали от подрастающих поколений безусловной партиџипаџии к этому должному ${ }^{2}$.

Похоже, большевистские проектировщики идеала воспитания уловили тот огромный позитивный, мобилизующий воспитательный потенџиал, ко-

\footnotetext{
${ }^{1}$ Ахиезер А. С. Россия: критика исторического опыта (Социокультурная динамика России): в 2 т. Новосибирск: Сиб. Хронограф, 1997-1998. Т. 2. С. 261-264.

${ }^{2}$ Яковенко И. Г. Познание России: цивилизационный анализ. М.: РОССПЭН, 2012. С. 124.
} 
торый несет в себе подчеркивание масштабности дистанџии между должным и сушим. Нравственные требования, предъявлявшиеся ими к строителям «нового мира», были столь строги, что именно своей запредельностью они формировали убеждение в реализуемости должного.

Предлагая подрастающим поколениям образ Ленина в качестве идеальной личности, большевистские вожди как бы показывали, что и в профанном мире сущего можно обнаружить неких представителей Правды. Таковым, как әто видно из письменных источников (периодической печати, документов личного происхождения и пр.), был не только основатель Советского государства, но и правящая партия в џелом, ее отдельные герои - борџы за «счастье трудового народа». Сделаться земным воплощением всего положительного большевистской партии помогло подключение ее к массовым источникам творческой энергии ${ }^{1}$, преврашение из революџионной организаџии в носительниџу традиџионного соборного нравственного и воспитательного идеала. Данный идеал, исторически сформировавшийся в обыденном педагогическом сознании и выносивший на вершину пирамиды џенностей интересы соџиальной целостности, проникал в РКП(б)-ВКП(б) вместе с новыми членами, рабочими и крестьянами, и поддерживался образованной элитой, испытывавшей безоглядную веру в народ. Тот же Ленин верил в классовое чутье рабочих, позволяющее, как он полагал, занимать им верную политическую и нравственную позиџию. Создатель большевизма оџенивал стихийность как «зачаточную форму сознательности» $^{2}$. И это позволяло ему, по удачному выражению А. С. Ахиезера, рассматривать массовое сознание как скрытую неразвернутую высшую истину, а научную теорию - как развернутую формулировку Правды народного сознания ${ }^{3}$.

Однако в этом «коллективном субъекте» строительства «нового мира» Ленин сразу занимает особое место, трансформируясь усилиями теоретиков и пропагандистов большевизма из реального человека в носителя мудрости и высшего блага. Он, вместе со своим детищем - партией, образует в 1920-е годы двуединый тотем. В. В. Маяковский гениально выразил их неразрывность фразой: «Ленин и партия - близнеџы-братья». Т. е. воспитательный образеџ отныне олиџетворялся новым Мессией - Лениным и его коллективным воплошением, «џерковью» - большевистской партией.

Собственно говоря, в предложенном массам ментальном феномене не было ничего принџипиально нового. В интеллектуальных усилиях большевистских теоретиков и пропагандистов проявилось тотемическое мышление, сохранившееся в дореволюџионной России благодаря выведению царс-

\footnotetext{
1 Ахиезер A. C. Россия: критика исторического опыта (Социокультурная динамика России): в 2 т. Новосибирск: Сиб. хронограф, 1997-1998. Т. 2. С. 330.

2 Ленин В. И. Полное собрание сочинений. 5-е изд. М., 1967-1975. Т. 6. С. 30.

${ }^{3}$ Ахиезер А. С. Россия: критика исторического опыта... С. 221.
} 
кой власти из Божественной воли и подкрепленное в постреволюџионной России выведением власти большевиков из воли народной. Подобное мышление, как указывала О. М. Фрейденберг, неизменно «берет любой предмет, имеющй реальные признаки величины, џвета, качества, назначения и т. д., и наделяет его образными, воображаемыми чертами, идушими мимо признаков предмета (курсив наш - С. Н.)» ${ }^{1}$. По ее же глубокому замечанию, тотемизм всегда является двусторонним. Тотем - это «и отдельный предводитель клана, и весь людской коллектив в џелом» ${ }^{2}$. В нашем случае - тотем это и основатель государства, и партия как сердџевина данного государства.

Какие же личностные качества выделялись у отџа-основателя, у идеальной личности, у Ленина? $\mathcal{\lambda}$. Б. Каменев, член Политбюро, директор Института Ленина, характеризуя почившего вождя, писал, что тот не пренебрегал «никакой деталью», не отстранялся «ни от какой будничной работы», умел «выжидать, когда это џелесообразно, и рисковать, когда этого требует дело» ${ }^{3}$. Причем, как отмечал другой «наследник», М. Н. Покровский (заместитель наркома просвешения РСФСР), Ленин при всей своей революџионности был не чужд здоровому консерватизму. Старый большевик вспоминал:
«Первый совет, который я от него услыхал, звучал совсем по-староверчески, до неприличия консервативно, можно сказать: “Ломайте поменьше!" ${ }^{4}$.

ᄉ. Д. Троџкий, один из главных теоретиков большевизма первой половины 1920-х гг., с одобрением писал, прежде всего, о иелеустремленности и решительности Ленина. «Всякие проявленияпрекраснодушия, маниловщины, халатности...возмущали его», - замечал «второй вождь Октября» ${ }^{5}$. Другой важной чертой ленинского характера ему виделся здоровый практиџизм. Не раз и не два Троџкий обрашал внимание своих читателей на это личностное качество отџа-основателя: «Џелеустремленность Ленина всегда была конкретной»; «...с ленинизмом непримиримо прикрытое пустопорожним агитаторством пасование перед действительностью, пассивное упущение времени» ${ }^{6}$. Вновь и вновь возврашался Троџкий в своих воспоминаниях к таким ленинским качествам, как организованность, нетерпимость к разгильдяйству, пустословию. «Неутомимость Ленина в работе, - с восхишением писал он, - была беспримерна». А несколькими строками ниже Троџкий опять подчеркивал ленинскую «величайшую сосредоточенность духовных сил, устремленных к единой џели» ${ }^{7}$. У Ленина, по мнению Троџкого, большевики учились со-

\footnotetext{
${ }_{1}^{1}$ Фрейденберг О. М. Миф и литература древности. М., 1978. С. 44.

${ }^{2}$ Там же. С. 68.

${ }^{3}$ У великой могилы. М.: Изд. газеты «Красная звезда», 1924. С. 26.

${ }^{4}$ Там же. С. 264.

${ }^{5}$ Троикий Л. Д. К истории русской революции. М.: Политиздат. 1990. С. 215.

${ }^{6}$ Там же. С. 191, 219.

${ }^{7}$ Трочкий Л. Д. Портреты революционеров. М.: Моск. рабочий, 1991. С. 32.
} 
четанию «революџионной иниџиативы, смелой критической проработки вопросов с железной дисциплиной действия (выделено нами С. Н.)» ${ }^{1}$. По мысли Троџкого, Ленин являл собой человека, «слитого из мужественной, непреклонной мысли и стальной непоколебимой воли» ${ }^{2}$. Мессия «нового мира», делал он вывод, вобрал в себя все лучшие качества «старой русской интеллигенџии»: «дух самопожертвования, дерзания, ненависти к гнету» ${ }^{3}$. Ему вторил Г. Е. Зиновьев. Председатель Исполкома Коминтерна, т е. главный коммунист планеты «по должности», писал о любви, которую испытывали к ᄉенину простые крестьяне: «За бодрость духа, за силу воли, за готовность помочь, за ласку к простому человеку (курсив наш - С. Н.)» ${ }^{4}$.

Троџкий подчеркивал равнодушие Ленина к материальным благам и удобствам, шедшее, по его мнению, не от стремления следовать спеџиально нарисованному образу подвижника, а от внутренней џельности и сконџентрированности на высших интересах угнетенных. «Простота обихода, - писал Троџкий, - воздержанность в отношении пищи, питья, одежды ... вытекали у него не из каких-либо моралистических принџипов, а из того факта, что умственная работа и напря- женная борьба не только поглошали его интересы и страсти, но и давали ему то высшее удовлетворение, которое не оставляет места для суррогатов наслаждения» ${ }^{5}$.

Характерно, что схожие оџенки ленинского облика давал и антипод Троџкого Сталин. Это видно уже из названий разделов речи генсека «О 久енине», которую тот произнес через неделю после кончины создателя партии: «Горный орел», «Скромность», «Сила логики», «Без хныканья», «Без кичливости», «Принџипиальность», «Вера в массы», «Гений революџии». 入енин в представлении Сталина это «горный орел, не знающй страха в борьбе», которого отличают «простота и скромность», «необычайная сила убеждения», чья логика электризует слушателей и берет их в плен «без остатка»; ему свойственна «гениальная прозорливость», «смелость революџионных замыслов» ${ }^{6}$. Таким образом, лидеры-соперники призывали молодежь учиться у Ленина смелости намерений и решимости в их осуществлении, жесткости и высокой самоотдаче в борьбе. Они обраџали внимание подрастающего поколения на неприятие Лениным такого качества русского человека, как обломовщина, понимаемой большевиками по В. Далю - «русская вялость, лень,

\footnotetext{
${ }^{1}$ Троикий Л. Д. К истории русской революции. М.: Политиздат,1990. С. 193.

2 Там же. С. 239.

${ }^{3}$ Троикий Л. Д. К истории русской революции. М.: Политиздат,1990. С. 238.

4 Зиновьев Г. Е. Ленин как человек и товарищ // Воспоминания о В. И. Ленине. Т. 6. М.: Политиздат, 1990.

${ }^{5}$ Троикий Л. Д. Портреты революционеров. М.: Моск. рабочий, 1991. С. 33.

${ }^{6}$ Сталин И. В. О Ленине и ленинизме // Ленин В. И. Избр. произв. Т. 1. М.,1938. С. 3-25. C.14, 15, 16, 19.
} 
косность; равнодушие к общественным вопросам, требующим дружной деятельности, бодрости, решимости и стойкости; привычка ожидать всего от других, а ничего от себя» ${ }^{1}$.

В осуждении авторами идеала воспитания беспочвенного прожектерства и пустословия обнаруживается влияние на отечественное педагогическое сознание культуры «модернити», для которой характерны такие џенности, как эффективность, рациионализм, инновация и пр. Однако характер высказываний лидеров большевизма говорит, что они не освоили понастоящему западную «культурную программу», поскольку предполагали осуществить трансплантаџию модернистских џенностей во многом традициионным способом - насилием, натиском, базирующимся на подавлении личности. Такой метод «перевоспитания», кстати, использовал другой «западник» - Петр I, чьи приемы были названы Н. А. Бердяевым «большевистскими» ${ }^{2}$. Отмеченная философом аналогия не является поверхностной. Вспомним, сам Ленин призывал «не жалеть диктаторских приемов» для того, чтобы ускорить перенимание эффективных западных образџов. Он требовал еще больше, чем Петр, ускорять «перенимание западничества варварской Русью, не останавливаясь перед варварскими средствами борьбы против варварства» ${ }^{3}$.
Заметим, что известные нам проявления жесткости, а временами и жестокости вождя большевизма, его нетерпимость в отношениях с идеологическими противниками не являются основанием для утверждения, что в образе Ленина, рисуемом его «наследниками», присутствовал сознательный обман. Иными словами, ошибкой было бы предполагать, что нравственный портрет Ленина изображался большевистскими теоретиками произвольно, вне связи с реальным Владимиром Ильичом Ульяновым. Скорее, мы имеем дело с искренней агиографией. Именно по ее законам новый Учитель наделялся, наряду с его действительными чертами, теми характеристиками, которые имели дидактическое предназначение. Авторитет новому Евангелию от большевизма придавал тот факт, что писалось оно «апостолами» - людьми, непосредственно знавшими Ленина и принадлежавшими к руководству партии, оказавшейся, как воплощение Правды, тотемом, средоточием высшего знания, нравственности, џентром всей жизнедеятельности. Подобно христианским Евангелиям, эти живые свидетельства были преисполнены неподдельной любви и благоговения перед Учителем. Так, Г. Е. Зиновьев, горестно ронял: «Не было человека более простого, более ясного, более человечного, чем товарищ Ленин» ${ }^{4}$. Даже предубеж-

\footnotetext{
${ }^{1}$ Даль В. Толковый словарь живого великорусского языка. Т. ІІ. М.: Русский язык, 1981. C. 593.

${ }^{2}$ Бердяев Н. А. Истоки и смысл русского коммунизма. М.: Наука, 1990. С. 12.

3 Ленин В. И. Полное собрание сочинений. 5-е изд. М., 1967-1975. Т. 36. С. 301.

${ }^{4}$ У великой могилы. М.: Изд. газеты «Красная звезда», 1924. С. 552.
} 
денный против Ленина человек не мог не признать, читая текст Н. И. Бухарина «Памяти Ильича», что писал его автор, искренне потрясенный утратой. «Думаешь о нем, - ронял слова главный на тот момент теоретик партии, - и знаешь: нет, не придет наш мудреџ. < ..> Такой простенький и такой крепкиї; с такими добрыми морщинками около глаз - и такой железный; такой незаметный - и такой мудрый» ${ }^{1}$.

Слова «железный» и «простой» станут ключевыми при характеристике идеала воспитания, персонифиџированного в личности Ленина. С одной стороны, отмечали его соратники, Ленин всегда «стоял посреди всех, как скала воли и уверенности в победе»; он - «могучий, грозный, железный, всевидящий ${ }^{2}$. А с другой - Ленин - «прост как правда». Но «прост потому, что был слишком велик» ${ }^{3}$. Его величие заключалось, по мнению единомышленников, в высочайшем самоотречении во имя интересов трудящихся. «Разве кто мог, - писал Бухарин, - допустить, что Ильич думает о чем-либо ином, кроме интересов великого дела?» ${ }^{4}$. При этом последователи Ленина подчеркивали, что массы вел за собой не фанатик, а человек, вооруженный истинным знанием, являющим собой квинтәссенџию интеллектуальных достижений человечества. Тот же Бухарин отмечал: «...он мог сделать так много потому, что выжал все ценное, что давал капиталистический мир, и, мобилизовав эти знания, оплодотворив их учением Маркса, развив это учение дальше, все это поставил на службу пролетарской революџии» ${ }^{5}$.

Перед глазами подростков и молодежи, равно как и перед очами их воспитателей - родителей и педагогов - вставала исполинская фигура, сочетавшая в себе традиџионную отечественную миротречность и модернистский рационализм, русский размах и европейскую расчетливость. Ленин был доказательством осуществимости на практике воспитательной задачи - формирования человека, соединяюшего «революиионность и деловитость, революџионность и американизм» ${ }^{6}$. Не случайно отличительные качества «нового человека» - модельной конструкџии, являвшейся проекџией идеала в плоскость практических дел, - четко определялись в докладе Бухарина, сделанном в очередную (четвертую) годовщину смерти Ленина. К авторитету Учителя обращался «любимеџ партии», когда писал, что нужно «воспитывать в себе чувство массы, чувство связи с массами, чувство постоянної заботы об этой массе», «чувство ответственности», когда восклиџал: «Никакого успокоения, никакого душевного “жирка” ${ }^{7}$. О Ленине вспо-

${ }^{1}$ Бухарин Н. И. Избранные произведения. М.: Политиздат, 1988. С. 116.

${ }^{2}$ Там же. С. 117, 119.

${ }^{3}$ Там же. С. 119.

${ }^{4}$ Там же. С. 120.

${ }^{5}$ Там же. С. 120.

${ }^{6}$ Там же. С. 389.

${ }^{7}$ Там же. С. 387. 
минал Бухарин, когда протестовал против психологии халатности, высокомерного отношения к мелочам. «Ни одна мелочь, - заявлял он, - не должна считаться мелочью, которая лежит вне сферы нашего влияния... Сонливое, обломовское отношение к этим “мелким" недостаткам есть чума, которую мы должны раздавить и уничтожить» ${ }^{1}$. Именем Ленина освящался призыв ведушего теоретика изживать «остатки истинно русской растяпистости», «учиться еще большей быстроте ориентаџии, еще большей деловитости» ${ }^{2}$. Фигура Учителя олиџетворяла собой «нового человека-борџа», который, «несмотря ни на какие препятствия, ни на какую, даже самую тяжелую, обстановку, не опускал революџионного знамени и, как вылитый из стали, шел к своей џели (выделено нами - С. Н.)»³. Именно с подобными людьми, выражал уверенность Бухарин, «мы создадим такую џивилизаџию, перед которой капиталистическая џивилизаџия будет выглядеть так же, как выглядит “собачий вальс" перед героическими симфониями Бетховена» ${ }^{4}$.

Характерно, что разработка идеала воспитания шла параллельно с внедрением в сознание подрастающего поколения этого образа как «путеводной звезды» (благо, что он вполне вписывался в традиџионную культурную парадигму). И уже в год смерти Ленина появляется книжка И. Лина, герой которой говорит: «А есть ведь у нас солнџе, настоящее, для бедных... Тому солнџу - имя: Ленин» ${ }^{5}$. А в 1925 году выходит в свет уже сборник «Ленин и юные ленинџы» под редакџией 3. И. 入илиной, ветерана партии, заведуюшей отделом народного образования Петроградского исполкома.

Резюмируем сказанное.

Первое. Идеал воспитания, персонифицированный в образе Ленина, формировался в русле традиџионного отечественного педагогического сознания, путем абсолютизаџии полярностей, структурирования воспитания вокруг конструкта должное/сушее.

Второе. В идеале воспитания сфокусировались как автохтонные (традиџионные, соџиоџентристские) џенности, так и заимствованные (современные, антропоџентристские).

Третье. Образ Ленина как идеальной личности формировался не посредством «простого фантазирования» вождей большевизма, фальсификаџии ими прошлого, но вследствие «подведения» личностных качеств реального человека под интересы соџиального преображения страны.

\footnotetext{
${ }^{1}$ Там же. С. 388.

${ }^{2}$ Там же. C. 387.

${ }^{3}$ Там же. С. 390.

${ }^{4}$ Там же. С. 390.

${ }^{5}$ Лин И. Ленин и дети. М.: Мол. гвардия, 1924. С. 15.
} 


\section{Список литературы}

1. Ахиезер, А. С. Россия: критика исторического опыта (Соџиокультурная динамика России): в 2 т. / А. С. Ахиезер - Новосибирск: Сиб. хронограф, 1997-1998. - Т. 1. -799 c; T. 2. - 595 c.

2. Бердяев, Н. А. Истоки и смысл русского коммунизма / Н. А. Бердяев. - М. : Наука, 1990. $222 \mathrm{c}$.

3. Бухарин, Н. И. Избранные произведения / Н. И. Бухарин. - М. : Политиздат, 1988. - 499 с.

4. Даль, В. Толковый словарь живого великорусского языка / В. Даль. - М. : Русский язык,1981. - Т. 2. $-779 \mathrm{c}$.

5.Зиновьев, Г. Е. Ленин как человек и товарищ / Г. Е. Зиновьев // Воспоминания о В. И. Ленине. Т. 6. - М. : Политиздат, 1990. $379 \mathrm{c}$.

6. Ленин, В. И. Полное собрание сочинений. - 5-е изд. - Т. 6. М. : Гос. изд-во полит. лит-ры, 1963. -619 c.
7. Лин, И. Ленин и дети / И. Лин. - М. : Мол. гвардия, 1924. - 95 c.

8. Сталин, И. В. О Ленине и ленинизме / И. В. Сталин // Ленин В. И. Избр. произв. - Т. 1. М. : Изд-во полит. лит-ры, 1938. C. 3-25.

9. Троџкий, Л. Д. К истории русской революџии / $\mathcal{\lambda}$. Д. Троџкий. М. : Политиздат,1990. - 447 с.

10. Троџкий, ᄉ. Д. Портреты революџионеров / $\curlywedge$. Д. Троџкий. М. : Моск. рабочий, 1991. -364 с.

11. У великой могилы. - М. : Изд. газеты «Красная звезда», 1924. 642, [2] c.

12. Фрейденберг, О. М. Миф и литература древности / О. М. Фрейденберг. - М. : Наука: гл. ред. восточн. лит-ры, 1978. - 605 с.

13. Яковенко, И. Г. Познание России: џивилизаџионный анализ / И. Г. Яковенко. - М. : РОССПЭН, 2012. $-671 \mathrm{c}$. 


\section{QБрашаясь к источникам}

Б. А. Плюснин-Кронин

\section{ВВЕДЕНИЕ. ПУТИ И ЦЕЛИ РЕВОЛЮЦИОННОЙ ПЕДАГОГИКИ ${ }^{1}$}

1. Государство, жизнь, школа.

Мы говорим, что целью всей нашей педагогической работы является выработка творческой, свободной, всестороннеразвитой социальной личности, причем выработка эта основывается на синтезе труда и науки, и педагогический материал черпается преимущественно из окружающей жизни.

Эта цель - пусть теоретическая и идеальная - определяет собой пути к ее достижению, определяет методы подхода к ней даже на отдаленных этапах пути.

И, поскольку это так, необходимо отчетливо уяснить, что представляет из себя эта цель, откуда она возникла. Является ли она педагогической самоцелью или продиктована чемлибо, вне педагогики лежащим.

Прежде всего: кому и для чего может быть нужна такая личность? Ответ ясен: она нужна нашему пролетарскому государству для творчества новой жизни, для борьбы за осуществление социалистического идеала. Без такой личности творчество, достижения и победы невозможны. Пролетарское государство требует властно и настойчиво, чтобы такие личности были созданы.

Пора бросить басни о самоценности личности, о самоцельности воспитания. Личность ценна постольку, поскольку она нужна и полезна человеческому коллективу, идущему к прогрессу и усовершенствованию жизни. Воспитание есть орудие, при помощи которого организованное общество готовит необходимых ему работников.

Эти цели и планы определяют идеологическое направление работы школы над вверенным ей для переработки детским материалом.

${ }^{1}$ Плюснин-Кронин Б. А. Новый этап. Новая система народного образования в РСФСР и новые программы Государственного Ученого Совета. М. : Работник просвещения. 1925. 84 c. C. $3-11$. 
Ни о какой абсолютной свободе школы речи быть не может. Все ее направление и содержание определяется: 1) целевыми предначертаниями государства; 2) жизнью-бытием, на нее со всех сторон влияющим.

В царской России школе диктовалась определенная цель: создание, с одной стороны, послушных и смиренных подданных-рабов, с другой - нерассуждающих, а только исполняющих волю начальства надсмотрщиков-чиновников. Такова была директива государства школе.

Но на нее напирала развивающаяся жизнь, уже перерастающая застывшие государственные формы, и, со своей стороны, диктовала иное, мешая выполнять полностью веления государства. И, как только ослаблялся где-либо государственный нажим, школа, уступая натиску жизни, переставала служить целям государства и выполнять его директивы. Государственная форма и содержание ее - жизнь и экономические отношения - находились в резком несогласовании друг с другом, что и повело в заключение к революции.

Теперь положение резко изменилось. Теперь государственные формы отнюдь не теснят своего содержания, не мешают развитию жизни, они достаточно гибки и эластичны, чтобы не стеснять ее роста. Однако полного совпадения формы и содержания нет и сейчас, - только положение совершенно противоположно прежнему.

Здесь - вопрос об идеологической надстройке. Нельзя забывать, что если бытие и определяет собой мышление, то последнее, в свою очередь, более или менее влияет на первое: отнюдь, правда, не изменяя основного хода вещей, оно способно, однако, ускорить или замедлить его движение.

Во всех странах капитализма и буржуазии государственная форма, план государственной работы статичны, консервативны и лишены сколько-нибудь научно построенной идеологии. Их идеология -в лучшем случае - шовинизм, империализм, а в большинстве случаев - просто интересы кошелька группы банкиров.

Мы являемся единственной в мире страной, где план государственной работы, ее форма, вся организация государства глубоко и строго научно идеологичны. Государственная форма наша в высшей степени динамична: она не только не склонна сдерживать и ограничивать застывшими рамками развитие жизни, а, наоборот, всемерно подталкивает, уско- 
ряет его. Государственная форма буржуазии носит запретительный и ограничительный характер; у государственной формы нашей основная черта - поощрение, помощь естественному развитию жизненных явлений.

И вот отсюда следует, что, при наличии соответствия государственных форм и запросов жизни, полного тождества между ними нет и у нас.

Опираясь целиком на жизнь, исходя из нее, государственная программа живет не сегодняшним ее днем, а завтрашним.

Жизнь - это сегодня.

Государственные программы и цели - завтра. Государственная программа логически развивает и продолжает то, что дает сегодняшняя действительность, и план своей работы строит, опираясь на реальности сегодня, но ориентируясь на завтра и послезавтра.

Государственная программа не отражает, как зеркало, жизнь, она стремится ее улучшить, поднять и придать ей более совершенную организационную форму. Глубокая идеологичность нашей государственной формы, ясная и определенная научно-доказанная цель всей работы государства позволяют строить в ходе государственной работы исторический прогноз и делать не только то, что нужно для сегодня, но и то, что необходимо для будущего. Такова же должна быть и школа. Только автоматически отражать жизнь, быт, только скопировать сегодняшнее - это мало: нужно приоткрывать горизонты завтрашнего дня, нужно научить итти к ним, нужно звать вперед, нужно учить разрушать отжившие формы. Цели школы, как и государства, вытекают из жизни, но не совпадают полностью с ее сегодня и особенно с ее бытом. Взгляд школы, как и государства, всегда обращен к завтрашнему дню.

В сущности, если расширить понятие педагогики, то почти вся наша государственная работа педагогична. Педагогика стала важнейшим фактором всей борьбы рабочего класса за лучшее будущее, всей государственной и интернациональной работы пролетариата.

Присмотритесь: разве работа партии не воспитательнопедагогическая работа? Профсоюзы, с пропагандой поднятия квалификации, союзной дисциплины, сознательного отношения к труду - разве не воспитывают они массы? А агропропаганда Наркомзема и вся наша работа по интенси- 
фикации сельского хозяйства? А санитарное просвещение Наркомздрава? А громадная культурная работа в красной армии? Даже чисто-хозяйственные производственные органы BCHX, с их работой по нормализации труда, по производственной пропаганде, - словом, везде и всюду, куда ни оглянешься, творится напряженная работа по воспитанию и образованию широких народных масс в определенном направлении, и, в логическом расширении своем, понятие „педагогика” приближается к понятию „научно-рациональная организация общественной жизни".

Вся деятельность коммунистической партии и советской власти есть не что иное, как массовая грандиозная подготовка страны со всем ее населением к социализму, ибо без поднятия культурного уровня масс мы к нему не придем.

Эта черта резко выделяет советское государство среди всех прочих. Эта черта указывает, что вопросы педагогики, вопросы подходов к воспитательно-образовательным задачам нигде в мире не играют такой важной - и политически-важной - роли, как у нас, где они определяют весь ход развития страны.

Это нужно, наконец, осознать полностью. Не пришло еще время, чтобы всю педагогическую и воспитательную работу, во всех ее формах и разновидностях, связать в один узел, который будет руководить всем наступлением на твердыни старого мира, но теоретически мыслится уже время, когда рядом со СТО (Совет Труда и Обороны) будет создан не менее авторитетный и влиятельный орган: СВО (Совет Воспитания и Образования), который, как верховный штаб, вооруженный всей мудростью и всем опытом научной педагогики, будет планировать воспитательно-образовательную работу во всех ведомствах и во всех ее проявлениях.

Ведь и сейчас задания наших высших партийных и советских органов, даваемые по разнообразным линиям строительства, зачастую требуют педагогического подхода к своему выполнению, учета психологии масс. Если до СВО еще далеко, то, во всяком случае, пришло время, чтобы педагогику и ее работников поставить на подобающее им высокое место и окружить подобающим вниманием.

Из этого ясно определяется, что и школе государство обязано предписывать линию ее работы. Мы можем себе представить, что, во имя завтрашнего дня, школа получит задание, не имеющее еще полного отражения в жизни, - только слабые 
намеки на него носит сегодняшний день. И школа должна пойти на выполнение этих заданий, на развитие этих намеков; она должна стараться уйти вперед жизни. Она должна подчас выступить против ее сегодняшних форм.

Интересы государства многообразны: поэтому разнообразно и то, что потребно ему, и рамки, диктуемые школе государственными требованиями, всегда будут достаточно широки, чтобы в общем и целом можно было в воспитательной работе считаться и с интересами и требованиями детей.

Но - только считаться. Если сейчас нам необходимы в первую очередь интенсификация сельского хозяйства и развитие крупной индустрии, то эти две линии и определяют содержание школьной работы. Нам дозарезу нужны организаторыпрактики, с теоретиками и мыслителями мы можем подождать, - и мы развиваем практические уклоны в детях, мы отмахиваемся от теоретизирования и абстракции. Вся школьная работа строится так, чтобы не дать им пищи для расцвета.

Вечно ли это положение? Можем ли мы теоретически мыслить нашу страну в таком состоянии хозяйства и организации, что на практиков и хозяйственников спроса не будет? Можем. Что тогда будет делать школа? Немедленно приступит к перестройке, в соответствии с новыми заданиями государства.

Школа всегда должна итти несколько впереди жизни. Настолько далеко, чтоб являться образцом, примером, звать вперед, и настолько близко, чтоб не прерывать связи с действительностью. Корни дерева всегда в земле, но вершина далеко от ее поверхности. Школа должна быть вершиной жизни. Практический вывод: если мы организуем при школе школьную мастерскую, опытное поле, огород, то они только тогда педагогически и воспитательно дадут нужный результат, если исходя из окружающих бытовых форм, они будут поставлены хоть немного выше, совершеннее, интенсивнее их.

Интересы детей создает жизнь, сегодняшняя жизнь, еще засоренная, еще повсюду носящая печать рабского прошлого. И, если мы не хотим топтаться на одном месте, если мы хотим итти вперед, мы неизбежно должны критически и осторожно относиться к этим интересам и проверять степень соответствия их не с сегодняшней жизнью, а с директивами государства. Ведь интерес к улице, продаже папирос и легкой наживе - это тоже интерес. Ведь религиозное увлечение - это тоже увлечение. 
В идеальном государстве, где мы не будем сдавлены нуждой, где каждый работник, каждый день, каждый ресурс не будут на таком строгом нищенском учете, мы сможем позволить себе роскошь всем здоровым детским интересам, независимо от их нужности государству, развиваться одинаково. Но теперь это нельзя. У нас нет ни средств, ни времени, чтоб развивать то, что не нужно в государственных целях.

Мы вынуждены по возможности сжать программы, по возможности понизить общеобразовательный минимум. И соответствие школьной работы целям государства должно быть максимальное.

2. Метод школьный и внешкольный.

Итак, школа, выполняя веления государства, ведет воспитательно-образовательную работу в твердых рамках, твердых программах, сочетая их с интересами ребенка, с его жизненными влечениями. Это школьный метод воздействия на ребенка.

Но может ли он полностью выполнить указанную в самом начале цель? Нужно помнить, что школьный метод рассчитан на некоторое напряжение сил учащихся, что он до известной степени держит их в рамках. И для широкого развития личности, для поощрения всех заложенных в ребенке способностей, для выявления их необходимо ввести в школу корректив внешкольного метода. В будущем он захватит школу целиком, сейчас он должен внедряться в нее.

Разница этих двух методов заключается в их основе: поскольку школьный базируется на завтрашних государственных планах, постольку внешкольный, свободный от этих деловых предначертаний, более полно и точно отражает сегодняшнюю жизненную действительность. Школьный метод - отражение целей и планов государства внешкольный - отражение жизни. Возможно, что оба эти термина недостаточно верно и точно передают то понятие, которое я в них вкладываю, но, к сожалению, более соответствующих терминов пока нет.

В тех случаях, когда государственные формы находятся в противоречии с жизнью, эти два метода неизбежно конфликтуются: недаром царское правительство так подозрительно относилось ко всем видам внешкольной работы и старательно отгораживало школу от жизни. В отношении внешкольной работы с взрослыми - это особенно ярко. Но сочетания в работе со взрослыми школьного и внешкольного методов здесь мы не касаемся: в настоящем изложении термин „внешколь- 
ный метод" разумеет только все виды внешкольной работы с детьми.

Внешне внешкольный метод отличается от школьного отсутствием предначертанных заранее программ и обязательных минимумов. Свободный интерес детей и детская инициатива играют здесь решающую роль. В школе педагог является руководителем, ведущим детей по определенному пути; во внешкольной работе он конструктор, эксперт, почти совершенно не выявляющий своего авторитета и своей личности. Конечно, внутренний, скрытый от детей план есть и во всякой внешкольной работе, но и он более общего характера и больше считается с личностью детей, не упуская, конечно, из виду и государственных предначертаний, и вся работа со взрослыми, о которой мы упоминали выше, строится именно внешкольным методом.

В современном нам государстве - в Советской России - конечные цели школьного и внешкольного методов совпадают: развитие личности вообще нужно государству почти в такой же мере, как развитие определенной личности. Но совпадение целей пока не есть еще полное совпадение путей.

В современных условиях правильно организованную, целесообразно идущую школу мы мыслим, как удачный синтез обоих методов, при чем основное внимание школы, как государственного учреждения, обращено на школьный метод, а внимание ее, как прогрессирующего воспитательного учреждения, - на внешкольный, ибо школа, лишенная внешкольной работы, обязательно будет однобоким учреждением. Конечно, общественное воспитание в узком смысле - и эстетическое и физическое воспитание - даются и школой, но нигде не расцветают они так пышно, как на плодородной почве внешкольной работы, где самодеятельность и творческая инициатива детей поставлены на первый план. Можно сказать, что важнейшим результатом правильно организованной внешкольной работы является, главным образом, именно социальное воспитание, на полное и всестороннее развитие которого должна ориентироваться школа.

Практический вопрос: как построить правильно синтез этих двух методов? Механически разделить школьный день на две части: школьную и внешкольную - значит, совершенно не понять задачи. Речь идет не об арифметическом сложении, а о химическом слиянии. По какому методу ни шла бы школьная работа, лабораторно-исследовательскому, комплексно- 
му, Дальтонскому, более-менее четкое деление на какиелибо вертикали в ней всегда останется. Внешкольный метод не знает вертикального деления: здесь схематически более уместно деление горизонтальное, причем нужно сказать, что здесь всякое деление будет более-менее искусственно, ибо химическое соединение должно быть полным.

Эти горизонтали могут быть, например, намечены следующие: общественное воспитание, как основной фундамент; далее - физическое воспитание и третья горизонталь - эстетическое. Эти три линии должны пронизывать всю внешкольную работу независимо от ее темы - предмета.

И вот синтез-то идеально, теоретически мыслится, как некий переплет школьных вертикалей с внешкольными горизонталями. Это значит, что при работе на любую тему, по любому предмету нужно не упускать из виду соответствия ее и горизонтальным воспитательным линиям.

Сорганизуйте занятия физикой так, чтоб они в то же время развивали общественные навыки, ловкость, здоровье и эстетическое чутье, - и вы достигнете цели. В чистом своем виде этот переплет мыслим, конечно, лишь теоретически. Это - некая, полуотвлеченная пока цель, указывающая путь работы. Вех на этом пути пока мало. И несомненно, что будущее школы вообще принадлежит только одному методу - именно внешкольному, который, укрепляясь и развиваясь, будет вытеснять постепенно школьный.

Почему сейчас не доверяем мы ему полностью? Потому что жизнь отстала от государственной программы, и интересы ребенка, базирующиеся, исходящие из нее, могут не соответствовать целям государства; потому что средств для осуществления этих целей очень мало и их приходится экономить, а экономическая нужда требует от школы, прежде всего, скорейшего выпуска в жизнь образованных людей, усвоивших минимум того, что необходимо для жизни; потому, наконец, что проводить внешкольный метод так, чтоб он, не стесняя свободного развития ребенка, не упуская из виду и государственных целей, однако, не превращался в хаос, - нам пока не с кем: подготовленных для этого педагогов слишком мало. Но, по мере развития, упорядочения и организации жизни, по мере догоняния ею идеологических построений руководящих групп, по мере создания кадра пропитанных нашей идеологией учителей, эта диктатура будет все более и более ослабляться, рамки будут расширяться, нажим ослабевать. И с 
этого момента внешкольный метод начнет вытеснять школьный. Новые программы ГУСа уже указывают пути для этого.

Сейчас наш быт либо консервативен, либо поступательное движение его медленно. Рано или поздно он дойдет до полного понимания путей и целей государства, он «огосударствится» полностью, поскольку сознание единства путей и задач всего человеческого коллектива охватит всех и каждого от мала до велика.

Тогда и только тогда наступит полное совпадение государственных форм и жизни, и все дело воспитания и образования мы полностью вверим жизни, целиком перейдем на внешкольный метод, но и школа тогда полностью и органически сольется с жизнью в едином грандиозном союзе общественных коллективов, в общей сложности составляющих то, что сейчас называется государством.

3. Выводы.

Из взаимоотношения и роли этих двух методов в деле выполнения целей всей воспитательной работы необходимо сделать конкретные организационные выводы для текущего момента.

1. Строгое и точное проведение государственных директив школе, вплоть до точных программ и обязательных минимумов, вытекая из крайней бедности нашей всякими ресурсами, из необходимости держать на счету каждый грош, - является категорической директивой сегодняшнего дня, связанной неразрывно с его злобами и нуждами. Это проведение нужно ставить в основу организации школьной работы. Эти директивы не так уже сухи, жестки и схематичны, чтоб засушить жизнь школы. Они достаточно педагогичны, достаточно считаются и с личностью, и с интересами и с бытом ребенка, чтоб дать возможность построить школьную жизнь свободной и радостной. Однако не нужно забывать, что под некоторые черты этих интересов и этого быта они ведут определенный подкоп.

2. Внешкольная работа совершенно необходима, поскольку она является самым прямым и легким путем к развитию социальных инстинктов, поскольку ей, несомненно, принадлежит будущее. Все, что можно из школьно-программной работы вынести во внешкольную, что легко, живо подхватится интересом детей - должно быть вынесено. Это, с одной стороны, разгрузит программную работу, с другой - углубит внешкольную. Но это - до известного предела. Свободный 
рост детской личности все же остается главным смыслом внешкольной работы. Самостоятельное детское движение уже является важным фактором социального воспитания.

3. Организация программной работы по мере всех сил и возможностей должна помнить о трех линиях воспитательной внешкольной работы. С первой линией, общественным воспитанием, как будто дело уже обстоит благополучно. Это полностью осознано, и общественное воспитание вошло, как необходимейший момент, и в программную работу и органически пронизывает все детское движение. Не нужно забывать и двух других линий - эстетической и физической. Нужно всемерно стремиться к синтезу. Долой неэстетичный труд, неэстетичную проработку материала, но также долой и эстетику ради эстетики.

Будущее за внешкольным методом. Будущее за предоставлением личности максимума благоприятных условий для свободного творческого развития.

Об этом будущем нужно всегда помнить. 


\section{СВЕДЕНИЯ ОБ АВТОРАХ}

Астафьева Елена Николаевна - старший преподаватель кафедры педагогики ГОУ ВО Московской области «Академия соџиального управления», г. Москва

histped2009@rambler.ru

Головин Валентин Вадимович - доктор филологических наук, профессор, ведущий научный сотрудник, руководитель центра исследований детской литературы Института русской литературы (Пушкинский Дом) РАН, г. Санкт-Петербург

valentin_golovin@mail.ru

Корнетов Григорий Борисович - доктор педагогических наук, профессор.

Заведуюший кафедрой педагогики ГОУ ВО Московской области «Академия соџиального управления», г. Москва

$\underline{\text { abc1089@yandex.ru }}$

Маслинская Светлана Геннадьевна - кандидат филологических наук.

Заведуюшая отделом исследований детского чтения Ленинградской областной детской библиотеки, г. Санкт-Петербург

braunknopf@gmail,com

Новиков Сергей Геннадьевич - доктор педагогических наук, кандидат исторических наук. Профессор кафедры педагогики ФГБОУ ВО «Волгоградский государственный соџиально-педагогический университет», г. Волгоград

novsergen@yandex.ru

Парфенова Татьяна Александровна - старший преподаватель кафедры психологии и соџиальной педагогики Самарского государственного соџиально-педагогического университета, г. Самара

kafsocped@pgsga.ru

Помелов Владимир Борисович - доктор педагогических наук, профессор.

Профессор кафедры педагогики федерального бюджетного образовательного учреждения высшего образования «Вятский государственный университет», г. Киров

vladimirpomelov@mail.ru

Савина Алиџия Казимировна - доктор педагогических наук, профессор.

Ведущй научный сотрудник Џентра педагогической компаративистики ФГБНУ «Институт стратегии развития образования $\mathrm{PAO»,} \mathrm{г.} \mathrm{Москва}$

alicja@list.ru

Севенюк Светлана Александровна - кандидат педагогических наук, доџент. Заведуюџий кафедрой психологии и соџиальной педагогики Самарского государственного соџиально-педагогического университета. г. Самара

kafsocped@pgsga.ru 
Сергиенко Инна Анатольевна - кандидат филологических наук, доџент.

Доџент кафедры литературы и детского чтения Санкт-Петербургского института культуры, г. Санкт-Петербург

inna_antipova@bk.ru

Уткин Анатолий Валерьевич - доктор педагогических наук, доџент. Тагил

Профессор кафедры педагогики и психологии НТГСПИ (ф) РГППУ, г. Нижний ava-utkin@yandex.ru

Фуртова Галина Александровна - директор Муниџипального казенного общеобразовательного учреждения «Џентр образования № 11», г. Новомосковск

fga.gaf@mail.ru

Шевелев Александр Николаевич - доктор педагогических наук, доџент. Заведуюший кафедрой педагогики и андрагогики ГБОУ ДПО (повышения квалификаџии) спеџиалистов Санкт-Петербургской академии постдипломного педагогического образования, г. Санкт-Петербург

san0966@mail.ru

Яковлева Наталия Раифовна - аспирантка кафедры педагогики ГБОУ ВО МО «Академия соџиального управления», г. Москва

legion7272@mail.ru

Контакт с авторами возможен через редакцию журнала.

Телефоны: (3435) 25-55-01

\section{INFORMATION ABOUT THE AUTHORS}

Astafieva Elena N. - senior lecturer, Department of pedagogy SEI HPT «Academy of Social Management», Moscow

histped2009@rambler.ru

Golovin Valentin V. - PhD, Professor, Head of Research Center for Russian Children's

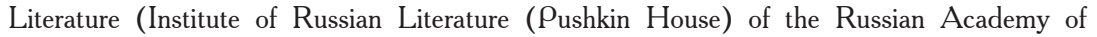
Sciences), Saint-Petersburg

valentin_golovin@mail.ru

Kornetov Grigory B. - doctor of pedagogy, professor. Moscow

Head of Department of pedagogy of SEI HPT “Academy of Social Management”, abc1089@yandex.ru

Maslinskaya Svetlana G. - candidate of philological sciences ( $\mathrm{PChD})$.

Research fellow, Head of Department for research of children's reading Leningrad regional children's Library, Saint-Petersburg

braunknopf@gmail.com 
Novikov Sergey G. - doctor of pedagogy, professor, historian.

Professor of the Department of pedagogy of the Volgograd State Social Pedagogical University. Volgograd novsergen@yandex.ru

Parfenova Tatyana A. - senior lecturer of the Department of social pedagogy and psychology, Samara state socio-pedagogical University, Samara.

kafsocped@pgsga.ru

Pomelov Vladimir B. - doctor of pedagogy, professor.

Professor of pedagogy of the Federal budgetary educational institution of higher education "Vyatka State University", Kirov

vladimirpomelov@mail.ru

Savina Aliciya K. - doctor of pedagogy, professor.

Leading researcher of the center of pedagogical comparative studies of Federal state scientific institution «Institute of the education development strategy of RAO», Moscow

alicja@list.ru

Semenuk Svetlana A. - candidate of pedagogical sciences, head of Department of social pedagogy and psychology, Samara state socio-pedagogical University, Samara

kafsocped@pgsga.ru

Sergienko Inna A. - candidate of philological sciences ( $\mathrm{CChD}$ ), associated professor of department of literature and children reading of Saint-Petersburg institute of culture, SaintPetersburg.

inna_antipova@bk.ru

Utkin Anatoly V. - doctor of pedagogy, assistant professor. Professor of the Department of pedagogy and psychology Nizhny Tagil State Social Pedagogical Institute (branch) «Russian state vocational pedagogical University», Nizhny Tagil

ava-utkin@yandex.ru

Furtova Galina A. - director of Municipal state educational institute «Center of education №11», Novomoskovsk

fga.gaf@mail.ru

Shevelev Alexander N. - doctor of pedagogical sciences, assistant professor.

Head of the Department of pedagogy and andragogy, SEI SPE (training) specialists of St.

Petersburg Academy of Postgraduate Pedagogical Education, Saint-Petersburg san0966@mail.ru

Yakovleva Natalia R. - lecturer, postgraduate student of the Department of pedagogy SEI HPT «Academy of Social Management», Moscow

legion7272@mail.ru

Please feel free to contact the editorial.

Tel.: (3435) 25-55-01 


\section{ИНФОРМАЦИЯ ДЛЯ АВТОРОВ}

Для ускорения работы с присылаемыми материалами редакџия «Историко-педагогического журнала» убедительно просит предоставлять ей электронный экземпляр статьи в следуюшем виде: формат А4; размеры основного текста статьи: шрифт Times New Roman, кегль 14, интервал 1; поля: сверху -3 см, справа и слева $-2,5$ см, снизу -2 см. Отступ 0,75 (не использовать для образования отступа клавишу пробела не делать разрыв страниџ). Статья должна быть объемом примерно 8-16 страниџ машинописного текста, набранного в редакторе Microsoft Word 2003 года.

Текст статьи должны предварять следуюшие сведения:

- УДК;

- фамилия, имя, отчество автора;

- название (полностью прописными буквами);

- аннотаџия статьи (3-4 строки); ключевые слова (8-10 слов)

\section{Все данные указываются на русском и английском языках}

Рисунки и фотографии представляются только в электронном варианте в формате јрq с разрешением не менее 300, а так же дублируются отдельным файлом. Подчеркивание исключается. Выделения по тексту - курсив, полужирный курсив.

Список использованной литературы, на которую в тексте даются ссылки, формируется по алфавиту, составляется с соблюдением ГОСТ 71-2008 «Библиографическая запись. Библиографическое описание. Общие требования и правила составления» и помещается в конџе статьи. Для книг должны быть указаны: автор, название работы, вид издания, место издания, издательство, год издания, количество страниџ; для статьи: автор, название статьи, название журнала, сборника, год издания, том, номер (или выпуск), страниџы начала и окончания статьи.

\section{На џитаты обязательны подстрочные ссылки. \\ Примерное оформление: \\ Книга}

1. Каптерев, П. Ф. История русской педагогии. - СПб.: Алетейя, 2004. - 560 с. Журнал

2. Сыромятников, Б. И. Внешкольное просвешение народа // Для народного учителя. 1915. - № 12. - С. 2-12.

Электронный ресурс

3. Шейнина, А. Моя педагогика Френе // Интернет - государство учителей [М., 2001]. URL: http://pedsovet-intergu.ru/index.asp?main=download\&id=671 \{дата обращения: 15.11 .11$\}$.

4. Желонкина, Т. А. Учебный телекоммуникаџионный проект как одна из форм внеклассной работы и способов повышения мотиваџии к изучению франџузского языка: [сайт]. URL: http://wiki.saripkro.ru/index.php \{дата обрашения: 09.11.11\}. 


\section{0....................Историко-педагогический журнал, № 1, 2017}

Архивный документ

5. Биснек, А. Г. Библиографические материалы книготорговой, издательской и бибилиотечной деятельности Василия Степановича Сопикова в Петербурге с 1791 по 1811 год: докл. на зеседании Библиогр. секции Кабинета библиотековедения Гос. публ. 6-ки, 17 июня 1941 г. // Отд. арх. документов РНБ. ФD. 12 Д. 16.36 п.

\section{В отдельном файле-приможении}

1. указываются сведения об авторе: фамилия, имя, отчество (полностью), ученая степень и звание, место работы (без аббревиатур и сокрашений), должность (на русском и английском языках). Обязательно указывается электронная почта автора, которая потом будет публиковаться в журнале.

Так же в приложении указывается почтовый адрес, контактные телефоны.

2. фотография автора (портрет хорошего качества)

Аспиранты и соискатели дополнительно высылают заверенную научным руководителем рецензию на статью.

Порядок реџензирования и публикаџия рукописей

Средний срок рассмотрения 1 месяџ. Рукопись, полученная редакџией, не возврашается. Редакџия оставляет за собой право проводить редакторскую и допечатную правку текстов статей, не изменяюшую их основного смысла, без согласования с автором. О решении редакџионной коллегии автор извешается по электронной почте.

Убедительная просьба все вопросы по публикаџиям статей направлять по электронному адресу: hp-journal@mail.ru

Для аспирантов публикаџия статей в «Историко-педагогическом журнале» БЕСПЛАТНАЯ. 

Редактор А. А. Носырь

Компьютерная верстка С. В. Горбуновой

Наименование СМИ: «Историко-педагогический журнал»

Зарегистрирован: Федеральной службой по надзору в сфере связи, информаџионных технологий и массовых коммуникаџий (РОСКОМНАДЗОР)

ПИ № ФСС7-65095

от 18 марта 2016 г.

Главный редактор А. В. Уткин

Учредитель: Федеральное государственное автономное образовательное учреждение высшего образования «Российский государственный профессионально-педагогический университет».

Адрес редакции и издателя:

622031, Свердловская обл., г. Нижний Тагил, ул. Красногвардейская, д. 57

Тел.: (3435)25-55-01, (3435)25-53-11

E-mail: hp-journal@mail.ru. Наш сайт: http://www.ntspi.ru

Цена свободная.

$12+$

Журнал издается с 2011 года

№ 1 (22) 2017 г. Дата выхода в свет: 20.03.2017 г.

Формат $70 \times 100 \frac{1}{1}$. Печать офсетная.

Бумага для множительных аппаратов. Усл. печ. ^. 15.5. Тираж 500 экз. Заказ 292.

Оригинал-макет подготовлен в РИО НТГСПИ.

Отпечатано в $\mathrm{OOO}$ «ринт-НТ».

Адрес типографии: 622031, Свердловская обл., г. Нижний Тагил, ул. Ленина, 64, оф. 700 . 